UNIVERSIDADE DE SÃO PAULO

FACULDADE DE FILOSOFIA, LETRAS E CIÊNCIAS HUMANAS

DEPARTAMENTO DE HISTÓRIA

PROGRAMA DE PÓS-GRADUAÇÃO EM HISTÓRIA ECONÔMICA

GIAN CARLO MACIEL GUIMARÃES HESPANHOL

Um estudo sobre o pensamento econômico de Delfim Netto

Versão final

São Paulo

2017 


\author{
UNIVERSIDADE DE SÃO PAULO \\ FACULDADE DE FILOSOFIA, LETRAS E CIÊNCIAS HUMANAS \\ DEPARTAMENTO DE HISTÓRIA \\ PROGRAMA DE PÓS-GRADUAÇÃO EM HISTÓRIA ECONÔMICA
}

\title{
Um estudo sobre o pensamento econômico de Delfim Netto
}

Gian Carlo Maciel Guimarães Hespanhol

\begin{abstract}
Dissertação apresentada ao Programa de PósGraduação em História Econômica do Departamento de História da Faculdade de Filosofia, Letras e Ciências Humanas da Universidade de São Paulo, como requisito parcial à obtenção do título de Mestre em História Econômica.

Orientador: Prof. Dr. Alexandre Macchione Saes
\end{abstract}

São Paulo

2017 
Autorizo a reprodução e divulgação total ou parcial deste trabalho, por qualquer meio convencional ou eletrônico, para fins de estudo e pesquisa, desde que citada a fonte.

Catalogação na Publicação

Serviço de Biblioteca e Documentação

Faculdade de Filosofia, Letras e Ciências Humanas da Universidade de São Paulo

H583e

Hespanhol, Gian Carlo Maciel Guimarães

Um estudo sobre o pensamento de Delfim Netto / Gian Carlo Maciel

Guimarães Hespanhol; orientador Alexandre Saes. - São Paulo, 2017. $258 \mathrm{f}$.

Dissertação (Mestrado)- Faculdade de Filosofia,

Letras e Ciências Humanas da Universidade de São Paulo.

Departamento de História. Área de concentração:

História Econômica.

1. Delfim Netto. 2. Pensamento Econômico. 3. Desenvolvimento

Econômico. 4. História econômica brasileira. I. Saes, Alexandre, orient. II. Título. 
Nome: HESPANHOL, Gian Carlo Maciel Guimarães.

Título: Um estudo sobre o pensamento de Delfim Netto

Dissertação apresentada ao Programa de Pós-

Graduação em História Econômica do

Departamento de História da Faculdade de

Filosofia, Letras e Ciências Humanas da

Universidade de São Paulo, para obtenção do título de Mestre em História Econômica.

Aprovado em:

Banca examinadora

Prof. Dr.

Instituição:

Julgamento:

Assinatura:

Prof. Dr.

Instituição:

Julgamento:

Assinatura:

Prof. Dr.

Instituição:

Julgamento:

Assinatura: 
To discover the truth of empirical existence, not to discover the empirical existence of the truth (Lucio Colletti) 


\section{Agradecimentos}

Agradeço à sociedade brasileira que me proporcionou auxílio financeiro para a realização dessa pesquisa, o qual me foi mensalmente repassado, durante dois anos, por meio da Capes. Que esse trabalho tenha alguma serventia àqueles que o financiaram.

Agradeço aos meus pais, que, estes sim, possibilitaram que a pesquisa se realizasse, dando-me todo o apoio necessário. Aos meus amigos, aos meus bons mestres, em especial, ao meu orientador. 


\section{Resumo}

HESPANHOL, G.C. Um estudo sobre o pensamento econômico de Delfim Netto. Dissertação (Mestrado). Faculdade de Filosofia, Letras e Ciências Humanas, Universidade de São Paulo, 2017.

A presente dissertação versa sobre o pensamento econômico de Antônio Delfim Netto. Para tanto, utiliza-se da leitura criteriosa dos principais escritos do autor entre os anos 1950-1967, contextualizando-os naquele período e visando analisá-los de forma coerente. No primeiro capítulo, aborda-se a formação recebida por Delfim durante o curso de graduação na FEA/USP, e o método que defendia para ser usado na ciência econômica. O segundo capítulo dedica-se à análise das ideias defendidas pelo autor em suas publicações durante a década de 1950. Três assuntos são mais debatidos: algodão, inflação e comércio internacional/câmbio. No terceiro capítulo, analisa-se a visão de Delfim sobre o problema do café no Brasil, e como trata a relação deste com as outras variáveis macroeconômicas, tendo em vista o maior desenvolvimento econômico. No quarto capítulo, a partir de seus textos da década de 1960, são discutidas suas concepções a respeito da necessidade do planejamento econômico, o papel que a agricultura deveria assumir no desenvolvimento e ainda sua visão sobre a inflação nesse processo. Concluise que os escritos de Delfim ao longo desse período são coerentes entre si, tendo sempre por trás a necessidade de planejamento para o maior desenvolvimento, sem poder relegálo ao livre jogo das forças de mercado. 


\begin{abstract}
HESPANHOL, G.C. A study of Delfim Netto's Economic Thougth. Dissertação (Mestrado). Faculdade de Filosofia, Letras e Ciências Humanas, Universidade de Sâo Paulo, 2017.

This study investigates Delfim Netto's economic thought. For this purpose, I examine his writings from 1950-67, contextualizing and analysing them in their respective historical period and in a coherent perspective. In the first chapter, I deal with Delfim's studies during his B.A. at FEA/USP and with his approach to the scientific economic method. The second chapter is devoted to analysing his 1950's writings in the light of three topics: "cotton production", "international trade" and "inflation". Chapter three deals with his interpretation of the "Brazilian coffee problem", the ways this subject were related to other macroeconomic variables and to Brazilian economic development. In the last chapter, I discuss his conceptions about the necessity of economic planning, the role of agriculture in economic development and his understanding of inflation in this process. The conclusion is that Delfim's writings during this period are consistent, as a critique of the free market underlies them, pointing to economic planning as a necessity for broader economic development.
\end{abstract}





\section{Sumário}

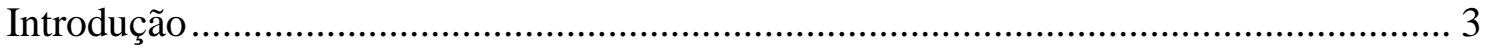

Capítulo 1 - A Formação como Economista.................................................................... 9

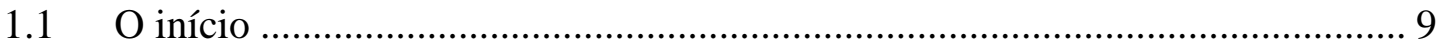

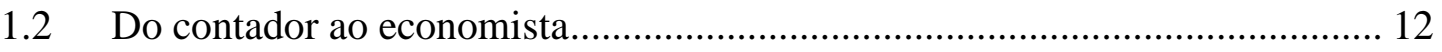

1.3 O método da economia para Delfim ......................................................... 26

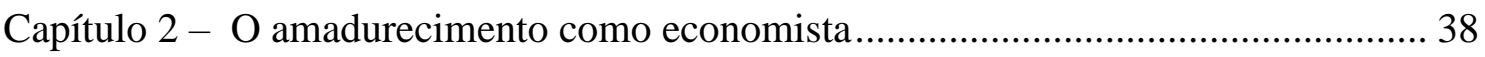

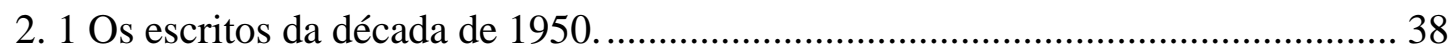

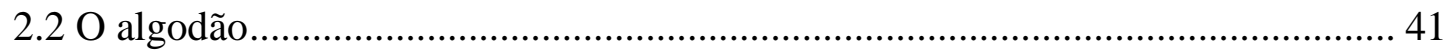

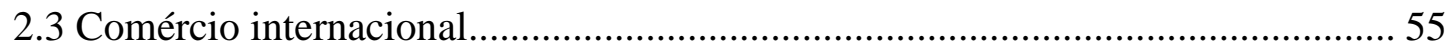

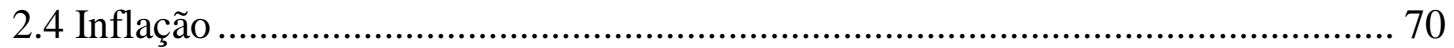

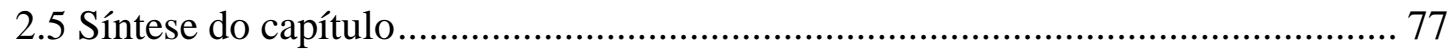

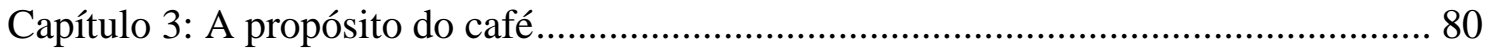

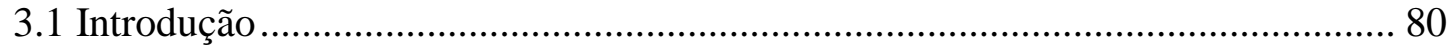

3.2 O Café, o Desenvolvimento Econômico e o Atraso ................................................ 80

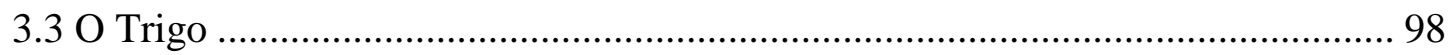

3.4 Diferentes perspectivas em 1959: Delfim e Furtado ....................................... 100

Capítulo 4: O economista à porta de Brasília: escritos dos anos 1960........................ 109

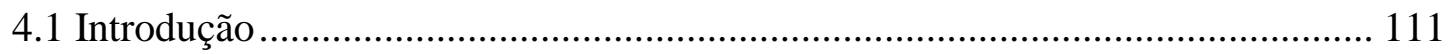

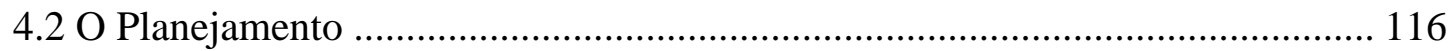

4.3 O papel da agricultura no desenvolvimento econômico brasileiro...................... 134

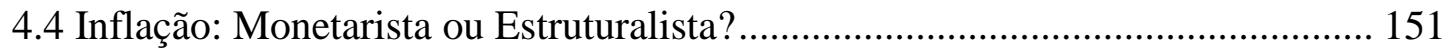

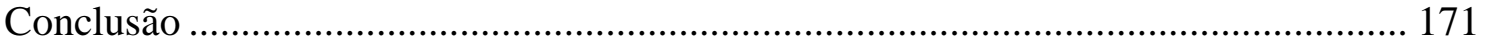

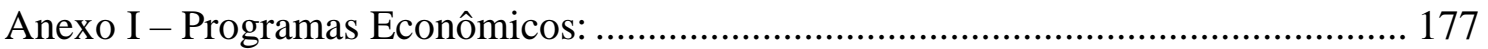


Anexo II: Roteiro de Leitura do Livro "O Problema do Café no Brasil"

Fonte

Artigos diversos

Artigos Bolsa de Mercadorias

Artigos Digesto Econômico. 228

Artigos Ciências Econômicas . 229

Bibliografia 231 


\section{Introdução}

No presente trabalho fez-se um esforço para se entender melhor o pensamento econômico de Delfim Netto, aluno mais "dileto" da Faculdade de Economia e Administração da Universidade de São Paulo (FEA). Esse esforço palmilhou o difícil caminho ao se relacionar a formação dele em sua graduação como economista e seus escritos com o momento histórico no qual estava inserido e com o qual dialogava. Para tanto, abarcouse o período de 1948 (ano de ingresso de Delfim na FEA) a 1967 (ano no qual Delfim tornou-se Ministro da Fazenda). O trabalho enxerga Delfim com uma trajetória intelectual coerente, podendo ser vistas suas principais ideias expostas ao longa da década de 1960 já em seus escritos de 1950, assim como sua formação inicial como economista (cujo término se deu no ano de 1952) influenciando muito em seu desenrolar de 15 anos até assumir a Pasta da Fazenda no Brasil em 1967.

Esta dissertação intencionou compreender a fundo as soluções econômicas propostas por Delfim ao se deparar com determinados problemas de ordem prática no Brasil nas décadas de 1950 até 1967. Não só entender essas soluções, como tentar compreender qual era o escopo holístico da perspectiva de Delfim para o Brasil e o mundo; qual seria a filosofia por detrás de seus apontamentos de cunho econômico; entre quais pensadores se poderia dizer que ele se balizava. O entendimento integral do pensamento de Delfim torna mais difícil a divisão entre tópicos (tais como inflação, desenvolvimento, balanço de pagamento, industrialização etc) pois todos esses, no fundo, estariam ligados a uma concepção maior, de necessidade de desenvolvimento da sociedade brasileira nos moldes capitalistas, sendo que a ciência deveria estar subordinada a esta noção. Não se pode, e.g., descolar o entendimento dele sobre qualquer assunto, sem o localizá-lo em determinado período histórico e lugar; por exemplo, a interferência do governo no café no Brasil não seria ruim a priori; o foi, por outro lado, por sustentar uma elite atrasada a qual, esta sim, atravancou a possibilidade de maior crescimento do Brasil tentando se perpetuar como elite. Na verdade, o próprio desenvolvimento do capitalismo estaria sempre em "xeque" dado que as "classes conservadoras" o impediriam de acontecer para manterem sua posição social. É por isso que ele advoga fortemente o planejamento como forma de permitir que o capitalismo avance, sem correr riscos; ou por causa das "classes conservadoras", ou por causa das "classes revolucionárias" que tentariam implementar

\footnotetext{
${ }^{1}$ Adjetivo utilizado para descrever Delfim Netto na própria sala "Delfim Netto" localizada na FEA-USP.
} 
um governo semelhante ao soviético. Talvez, em um mundo no qual não houvesse a alternativa do comunismo, ou, ainda, onde não houvesse monopólios mundiais, o planejamento não seria necessário, podendo o direcionamento econômico e, porque não, social ser relegado ao acaso (ou, forças de mercado). As variáveis tempo e espaço, são, assim, determinantes para se entender o pensamento de Delfim.

Objetivou-se (por meio da análise cuidadosa destes escritos e, sua comparação com o momento histórico) entender melhor como e de que forma um dos grandes economistas brasileiro entendia a economia e suas propostas. Para tal, a análise foi feita, em primeiro lugar, estabelecendo uma perspectiva cronológica dos escritos, na tentativa de se tentar encontrar algum padrão que pudesse vir com o avançar do tempo. Pouco se altera em em matéria de "interpretação de mundo" nos escritos, e, muito por isso, o segundo passo foi agrupá-los em tópicos e temas. Assim, o método de análise difere daquele da exposição desta dissertação. Todavia, algum corte cronológico houve, pois, o capítulo 2 trata dos escritos publicados durante a década de 1950, enquanto, o quarto, se concentra naqueles publicados nos anos 1960. Isso se explica, não por uma mudança de pensamento drástica (a qual não houve), mas, sim, pela evolução natural dos anos, nos quais outros problemas foram surgindo, como outras perspectivas tiveram de ser debatidas. Assim, por exemplo, falar de inflação no começo da década de 1950 e no meio de década de 1960 é um tanto quanto diferente, pois um pequeno problema acaba se tornando bem maior. É dessa maneira, também, que os assuntos a serem debatidos vão surgindo e tomando importância, conforme a pauta do dia. É por isso que alguns temas tendem a se concentrar em determinados anos. Por outro lado, por exemplo, o tema do problema de balanço de pagamentos esteve sempre presente para Delfim, contudo, com o agravamento da crise externa no Brasil (com o passar do tempo), este tema foi se subordinando - cada vez mais - ao próprio problema de perspectiva de desenvolvimento. Não que nos primeiros escritos de Delfim esta perspectiva não estivesse presente, mas ela não se apresentava como a tônica principal, mesmo que no fundo a fosse. Na década de 1960, essa situação se altera: a tônica principal passa a ser o desenvolvimento, e o problema do balanço de pagamentos (além da inflação, agricultura e café) se lhe subordina. Este movimento se apresenta não numa inversão propriamente de valores de Delfim (porque, como dito, a percepção de mundo não se altera fundamentalmente), mas as mudanças de 'tônica' (como aqui chamado), refletem, por outro lado, a mudança de cenário no qual nosso autor se encontrava, onde se exigia que certos assuntos fossem mais destacados do que outros. $\mathrm{O}$ 
caso mais claro é na discussão do algodão. No primeiro lustro da década de 1950, o produto algodão - e seus derivados - são de extrema relevância para Delfim, contudo, com a mudança de preços mundiais ${ }^{2}$ em favor ao café, ele perde espaço no discurso de Delfim (exatamente, porque, sua importância mingua na economia brasileira), tornandose - quando muito - marginal nos discursos posteriores do autor. O que evidencia que o assunto em si não era a principal importância, mas, sim, a "cosmovisão" que o fazia defender aquela posição; a qual consistia, basicamente, em investir na produção de algodão ao invés de investir na do café. Como se costuma dizer, o todo ("cosmovisão") estaria contido nas partes (assuntos específicos abordados por Delfim).

Coube, então, o problema de descobrir qual seria essa cosmovisão. Percorrer esta trilha é sempre um desafio, não só por ser um trabalho árduo, mas, principalmente, porque sua conclusão baseia-se em uma falácia (afirmação do consequente). Depende-se, fundamentalmente, de, por meio da análise daquilo que se apresenta, entender uma hipótese fundamental (aqui chamado de cosmovisão ou visão de mundo), e se a há, ou não. Assim, a pesquisa encontrou uma cosmovisão, a qual este trabalho apresenta e que não pode ser desmentida pelos escritos do autor, conquanto não absoluta e única possível. A cosmovisão de Delfim se apresenta como a necessidade do desenvolvimento econômico para o melhoramento da sociedade, destruindo estruturas e elites atrasadas, ao mesmo tempo que há a perspectiva de que elites atrasadas "ancorem" o desenvolvimento para não perderem suas posições privilegiadas na economia. Esse desenvolvimento haveria de se dar dentro do capitalismo (Delfim é sempre combativo ao comunismo) porém, o capitalismo liberal serviria à manutenção das elites atrasadas, enquanto o planejamento seria a única forma de superar a vontade daqueles que - por razões egoísticas - impediriam o desenvolvimento econômico.

Não há dúvidas de que Delfim foi importante ator político na história recente do Brasil. Ministro da Fazenda no período 1967-1974 e Ministro do Planejamento na década de 1980; foi deputado federal por cinco mandatos consecutivos e, posteriormente, nos anos 2000, foi consultor informal do Presidente Lula e Dilma. Delfim não fora político antes de se tornar Ministro pela primeira vez, e, ainda, o início de sua trajetória é claramente de dedicação à academia e ao conhecimento. Se é verdade que todo conhecimento é político, também não se nega que o conhecimento produzido por Delfim antes de 1967, sem

\footnotetext{
${ }^{2}$ Além de outros fatores, como a própria atuação do governo, que são apresentados nessa dissertação, em especial no capítulo terceiro
} 
dúvidas, o auxiliou a ser alçado a ministro com apenas 38 anos de idade. É, então, no entender da perspectiva de Delfim - não só, mas em especial, em relação à economia que se pode começar a entender quais eram os desígnios daqueles que o queriam como condutor da economia. Pouco se foi feito nesse sentido. Mantega (1997), en passant, se refere a Delfim (e uma suposta escola paulista), apenas como um conjunto de "toda sorte de influências Keynesianas" (Mantega, 1997, p. 112). Bresser-Pereira, trata mais do momento político no qual o Brasil se encontrava no ano de 1967, e, por meio de alguns discursos de Delfim publicados naquele ano, faz uma análise deste, em contraste com os ministros do Governo anterior (Roberto Campos e Bulhões), sendo, portanto, uma análise extremamente pontual, que se propunha a outros objetivos. Dois autores, por outro lado, em curtos artigos, se debruçam especificamente sobre Delfim: Macedo (2001) e Coelho (2007), os quais fazem uma mistura de memorialismo pessoal e biográfico com a análise de alguns poucos textos de Delfim Netto, muito pouco tocando no diálogo deste com o momento histórico no qual vivia. De acordo com a interpretação destes, pouco se é possível compreender a "cosmovisão" de Delfim, como se ela não existisse, ou, ainda, como se estivesse subordinada aos conceitos econômicos tais como "balanço de pagamentos", “café”, "inflação" etc.

Considera-se a interpretação do trabalho de Delfim aqui proposta diferente de todas as outras que já há. Ela se debruça com detalhes sobre o maior número de textos do autor encontrados, e retorna a partir deles, uma interpretação coesa, a qual conversa com a realidade que se pretendia transformar. Essa interpretação se apresentou coesa, não por critério do pesquisador, mas pelo que foi encontrado nos escritos, os quais indicaram haver uma linha mestre nos escritos de Delfim. Almejou-se trazer a público uma perspectiva ainda não explorada sobre a forma de se pensar e interpretar o Brasil que representava a obra de Delfim.

Nos dizeres de Schumpeter ([1954] 2006), haveria três formas possíveis de análise sobre a história do pensamento econômico: i) a "História da Análise Econômica" seu objeto de estudo e, o qual, pode ser entendido, de maneira geral, de análise sobre as ideias econômicas em seu sentido mais puro; ii) "História dos Sistemas de Economia Política", que são "um amplo conjunto de políticas econômicas que os autores sustentam tendo por fundamento determinados princípios unificadores (normativos), como os princípios do liberalismo econômico", com a qual parece que Mantega se alinha; e, iii) a História do Pensamento Econômico como "a soma total das opiniões e desejos referentes a assuntos 
econômicos especialmente relativos à política governamental que, em determinado tempo e lugar, pertencem ao espírito público.”

O primeiro destes pontos será o qual norteará a obra de Schumpeter. A história da análise econômica seria a teoria econômica em si, dos conceitos e instrumentos científicos (do ponto de vista da ciência empírica) usados pelos economistas para se compreender a realidade. Não se pode dizer que seja uma categoria exata, mas sim, que se define melhor em oposição às outras duas. O segundo, sistema de economia política, pode-se defini-lo como qual tipo de sistema econômico seria defendido pelo autor; seria o estudo de como aquelas ideias, do economista estudado, encaixar-se-iam no tipo de sistema econômico por ele defendido. Já o terceiro, o pensamento econômico, podemos entendê-lo com aquilo que o momento histórico incute nas personagens do período.

A história da análise econômica seria, portanto, o restante ao se separar a história da política econômica e as opiniões e desejos que acompanham o evoluir da economia ao longo do tempo. De maneira geral, haveria de se separar os "humores do tempo" da análise econômica pura. Claro que, ao longo de sua obra, Schumpeter acaba por ceder, e incorpora as outras análises em seu texto, ainda mais, porque, talvez essa separação seja melhor feita nas ideias, do que propriamente na prática.

Posteriormente, Blaug ([1962] 2001) propõe duas novas categorias, mantendo, ainda, alguma relação com as de Schumpeter. Seriam elas, a abordagem absolutista (ou reconstrução racional) e a abordagem relativista (ou reconstrução histórica). As categorias de Schumpeter "ii) História dos Sistemas de Economia Política" e iii) "História do Pensamento Econômico" podem ser encaixadas como abordagem relativista. Assim, o trabalho de Blaug segue a abordagem absolutista, mantendo, em linhas gerais, a metodologia usada por Schumpeter. Contudo, enquanto a obra deste é mais generalista do que o que ele próprio se propõe a fazer, Blaug se mantém circunscrito estritamente a sua metodologia proposta.

Desdobrando essas categorias, Screpanti e Zamangni (2005, p. 1 et seq.) observam dois tipos de perspectivas possíveis dentro da absolutista. A primeira, adotada por economistas como Knight, Stigler e o próprio Blaug³, é a “incrementalista”. Como o próprio nome parece sugerir, a ciência econômica nesta perspectiva é vista com um processo somatório, na qual cada teoria posterior incrementa, pouco a pouco, a anterior.

\footnotetext{
${ }^{3}$ Em seu manual Economic Theory in Retrospect.
} 
Nesta análise não haveria muito espaço para rupturas ou crises, trata-se de uma história das verdades econômicas. A segunda perspectiva seria a "catastrofista", influenciada pelo modelo de Kuhn: o conhecimento evolui por meio de revoluções ocasionadas pelas anomalias no paradigma dominante.

A perspectiva adotada no presente trabalho está longe de ser uma "análise econômica pura", na qual se exporia apenas os argumentos econômicos. Procurou-se, sempre, entender a perspectiva econômica de Delfim sem dissociá-la dos "humores políticos" da época. Muito porque a própria discussão de Delfim se apresentava (em especial na década de 1950) antes política do que propriamente como um tratado de lições econômicas. O autor não apresenta nenhuma obra (ou um escrito se quer) que tratasse apenas de modelos econômicos ou teorias. Estes estariam sempre em interlocução com os processos políticos e históricos do momento. Dessa maneira, entende-se que a análise puramente "absolutista" (seja "catastrofista" ou "incrementalista"), ou de "história da Análise Econômica" como propõe Schumpeter, seria deturpar o objeto de estudo, cuja obra é indissociável do meio no qual estava inserido.

Essa dissertação é dividia em quatro capítulos, além dessa introdução e uma conclusão ao final. O capítulo um é divido em duas partes. A primeira investiga o ambiente do ensino econômico e as matérias da FEA/USP à época que Delfim estudou lá como aluno da graduação, e, a segunda, explora qual era a noção de método científico, para Delfim, que deveria servir para conduzir o economista em suas pesquisas. O segundo capítulo explora os artigos de Delfim ao longo da década de 1950. Três temas são destacados; a questão do algodão no Brasil, o sentido do comércio internacional para Delfim e a visão da inflação para o autor naquele período. No terceiro capítulo, discute-se a perspectiva de Delfim quanto ao café em relação ao Brasil, algumas considerações sobre o trigo para Delfim, e, por último, compara-se as diferentes perspectivas entre Delfim em seu livro “O Problema do Café no Brasil”" ([1959] 2009), e Celso Furtado, no livro "Formação Econômica do Brasil” ([1959] 2007). No quarto capítulo, discutem-se as obras publicadas nos anos 1960. Destas, três tópicos são mais fortemente discutidos: o planejamento econômico, a agricultura, e a inflação. 


\section{Capítulo 1 - A Formação como Economista}

\subsection{O início}

Antonio Delfim Netto nasceu na cidade de São Paulo no dia $1^{\circ}$ de maio de 1928. Órfão de pai, aos 14 anos começou a trabalhar como contínuo das indústrias Gessy Lever. Estudou no colégio Liceu Siqueira Campos e, posteriormente, na Escola Técnica de Comércio Carlos de Carvalho, de onde saiu, em 1946, como contador, título então sem nível superior (MACEDO, 2001). Já nessa época, escrevia sobre economia para os jornais "Folha da Tarde" e "O tempo" (ABREU ET AL., 2010). Em 1948, ingressou na Faculdade de Ciências Econômicas e Administrativas da Universidade de São Paulo (FEA/USP). Essa, à época denominada FCEA (Faculdade de Ciências Econômicas e Administrativas), teve sua criação prevista no Decreto de criação da USP (1934), todavia só se concretizou em 25 de janeiro de 1946 com o Decreto-Lei $\mathrm{N}^{\circ} 15.601$ do interventor federal em São Paulo, José Carlos de Macedo Soares (PINHO, 2006). Delfim fazia parte, portanto, de terceira turma da FEA. "O sonho era engenharia, mas o dinheiro da família era curto para um curso puxado, que não lhe permitiria trabalhar meio período" (SAFATLE, 2012). De tal feita, logo nos primeiros anos de curso passou a trabalhar no $\mathrm{DER}^{4}$ (Departamento de Estradas de Rodagem), onde teve oportunidade de redigir alguns trabalhos na área de economia como: "Uma estimativa de custos de operação dos equipamentos rodoviários" e "Alguns métodos estatísticos para cálculos de depreciação numa economia sujeita à inflação" (ABREU ET AL, 2010).

Presidiu o centro acadêmico da FEA em 1951, seu último ano de bacharelado. O que poderia já evidenciar, de alguma forma, a figura de líder que teria em seu meio. A expressão “Delfim's boys” é representativa nesse assunto. Em 1952, logo após graduarse em economia, tornou-se o segundo assistente do professor Luís Freitas Bueno da cadeira de Estatística I. Em 1953, ministrou um curso de Análise Matemática para economistas da Bolsa de Mercadorias de São Paulo. Foi por meio das publicações mensais do periódico dessa instituição que começou a publicar seus primeiros escritos técnicos em economia. Em 1956 foi eleito paraninfo da turma que se formava naquele

\footnotetext{
${ }^{4}$ Nas palavras de Delfim: "Fiz então um concurso público, que era a forma clássica de obter subsídio governamental, e me tornei funcionário do DER, Departamento de Estradas de Rodagem. Aí, já era possível me acomodar." (ALBERTI; SARMENTO; ROCHA, 2002, p. 85)
} 
ano (DELFIM NETTO, 1957). Em 1959, tornou-se livre-docente ao defender a tese "O problema do café no Brasil", além de ter sido eleito vice-presidente da Ordem dos Economistas de São Paulo e membro do conselho editorial da "Revista de Ciências Econômicas" (SAFATLE, 2012). No ano seguinte, integrou o Grupo de Planejamento (GP) do novo governo paulista o qual era chefiado por Carlos Alberto de Carvalho Pinto. Nesse governo ocorreu a primeira tentativa de planejamento em nível estadual (CHIQUITO, 2011, p. 155). Tendo Plínio de Arruda Sampaio encabeçando a Secretaria do Planejamento, Delfim Netto era como uma peça importante do Plano. Ao fim do mandato de Carvalho Pinto, em 1963, Delfim Netto foi nomeado diretor do Departamento de Planejamento Econômico e Social (DPES) parte integrante da chamada Comissão Interestadual da Bacia do Paraná-Uruguai (CIBPU). Nesse cargo, trouxe consigo alguns ex-alunos da FEA. Entre eles, destacam-se, Akihiro Ikeda responsável pela análise populacional, Paulo Yokota, pela análise do setor industrial e José Roberto Mendonça de Barros responsável pela análise do saneamento urbano (CHIQUITO, 2011, p. 212)

Nesse período, na Universidade, ressalta-se o concurso para a cadeira XXV - "Economia Brasileira; Planejamento Governamental; Teoria do Desenvolvimento Econômico" (DELFIM NETTO, 1962), aprovado com louvor, em 1962, com a tese "Alguns Problemas do Planejamento para o Desenvolvimento Econômico". Ainda, podemos destacar o cargo de diretor de pesquisa do Instituto de Pesquisa Econômica (IPE), do qual fora membro fundador em 1964, e membro do Conselho Universitário FEA/USP.

Já, fora da academia, na década de 1960, Delfim começa a ascender na política brasileira. De uma posição de destaque no governo de São Paulo, a culminar no governo federal como Ministro da Fazenda. Podemos citar as funções de "membro do Serviço Estadual de Mão de Obra da Secretaria do Trabalho" do governo estadual e do "Conselho Técnico Consultivo da Assembleia Legislativa" (ABREU, 2010). No ano de 1965, começa a atuar em nível federal ao ingressar no conselho Consultivo de Planejamento (Consplan), órgão de assessoria à política econômica do governo Humberto Castelo Branco. Defendeu, em linhas gerais, o Plano de Ação econômica do Governo $(\mathrm{PAEG})^{5}$, e por indicação de Roberto Campos - Ministro do Planejamento à época - integra o Conselho Nacional de Economia. Em 1966 recebe a nomeação para um posto executivo na área econômica,

\footnotetext{
${ }^{5}$ Com ressalvas, principalmente ao que tange a política agrícola e monetária, como se verá ao longo do trabalho.
} 
assumindo a Secretaria da Fazenda do Estado de São Paulo no governo de Laudo Natel após a cassação de Ademar de Barros. No mesmo ano, atua como um dos membros fundadores da APEC, Associação de Pós-Graduação em Economia, no famoso Encontro de Itaipava. No ano seguinte, então com apenas 38 anos, é nomeado Ministro da Fazenda, posto no qual permanece até 1974. Época de intenso crescimento econômico e controlado nível de inflação, o qual recebe a alcunha de "milagre econômico".

Após deixar a pasta da fazenda, assume o cargo de embaixador do Brasil na França no período 1975 a 1978. De acordo com Delfim, havia um propósito político nesse intento. Tamanho os louros recebidos à época pela população - que lhe atribuía como o grande responsável pelo período de prosperidade do "Milagre" - os militares o impediram de se candidatar a um cargo executivo: “O exílio concebido por Geisel tinha como propósito abortar a pretensão do ex-ministro de candidatar-se ao governo de São Paulo e vir a ser, eventualmente, candidato à Presidência da República" (SAFATLE, 2012). Retornando em 1979 é nomeado Ministro da Agricultura e ministro-chefe da Seplan ${ }^{6}$. No mesmo ano, é nomeado ministro do Planejamento do Brasil permanecendo no cargo até 1985. Período de conjuntura econômica completamente diversa de quando fora Ministro pela primeira vez. Nas próprias palavras do ex-ministro: “fizemos uma recessão violenta, mas em 1984 não tínhamos mais déficit em contas correntes, o que permitiu que o país voltasse a crescer" (DELFIM NETTO, 2012).

Em 1985, junto à redemocratização, deixa o ministério para se candidatar em 1987 a deputado federal pelo PDS. Mesmo ano no qual é homenageado pela Faculdade com o título de Professor Emérito. É reeleito quatro vezes consecutivamente deputado federal pelo Estado de São Paulo nos períodos de 1987 até 2003. Deixando o posto em 2007, passa a ser consultor não-oficial dos chefes do executivo, assim que Fernando Henrique Cardoso deixa o cargo (AMARAL, s/d e CRUZ; FOREQUE, 2012).

Ao resumir alguns dos feitos do professor, explicita-se o papel extremamente importante que exerceu - e ainda exerce - na história do nosso país. De ministro da Fazenda no período de maior crescimento econômico da história do Brasil a consultor dos últimos dois presidentes, passando por cinco mandatos de deputado federal consecutivos, além de autor de inúmeros livros e artigos de jornais. Na parte acadêmica foi - e continua sendo

\footnotetext{
${ }^{6}$ Secretaria de Planejamento da Presidência da República
} 
- presença indiscutível na consolidação da FEA/USP, autor de uma das teses mais importantes sobre o café no Brasil.

\subsection{Do contador ao economista}

\subsubsection{O curso na FEA}

A admissão de Delfim na FEA em 1948 para cursar Ciências Econômicas foi possível, somente, devido a uma alteração de uma lei: a partir de 1945, o curso de bacharel em Economia foi equiparado com outros cursos universitários. Antes, para se tornar economista era necessário passar pela formação comercial, fato abarcado pela regência do Decreto n ${ }^{\circ} 20.158$ de 30 de Junho de 1931, o qual estabelecia a organização do ensino comercial. Por esse decreto, passava-se a existir um curso superior de Administração e Finanças, que concederia o título de Bacharel em Ciências Econômicas, e o Ensino Comercial propriamente dito, como curso técnico com três opções de formação, depois do cumprimento do propedêutico de duração de 3 anos em Secretariado, Guarda-Livros, Administrador-Vendedor, Atuário e Perito Contador (SAES ET AL, 2014, p. 20). Antes de 1945, o pretenso Bacharel em Economia deveria passar, necessariamente, pelo ensino comercial. ${ }^{7}$ Após 22 de setembro desse ano, foi assinado por Getúlio Vargas o DecretoLei n ${ }^{\circ}$ 7.988, separando o curso de Administração e Finanças do ensino comercial. Foram, então, criados os cursos de Ciências Econômicas e o de Ciências Contábeis e Atuariais, ambos com quatro anos de duração. Dessa forma, permitindo a alguém como Delfim, egresso de um colégio técnico, pudesse ingressar no curso de Ciências Econômicas.

Outra lei importante para a trajetória acadêmica do Delfim foi o Decreto-Lei n ${ }^{\circ} 15.601$ de 25 de Janeiro de 1946 do Interventor federal em São Paulo, José Carlos de Macedo

\footnotetext{
${ }^{7}$ Nas palavras de Saes et Al. (2014, p. 20): “Tornando-se uma formação complementar ao ensino tradicional de comércio existente nas décadas anteriores e, ganhando assim, uma mais complexa qualificação e valorização. Buscava-se equiparar, desta maneira, sua formação com de bacharéis de longa tradição: os advogados, médicos e engenheiros. Os dois primeiros cursos que seguiram as diretrizes do decreto foram formados ainda em 1931: na capital da República, o curso da Faculdade de Ciências Políticas e Econômicas do Rio de Janeiro e, em São Paulo, o curso da Faculdade de Ciências Econômicas de São Paulo, instalado na Escola de Comércio Álvares Penteado. Ambos os cursos formam suas primeiras turmas em 1934, turmas responsáveis também pela fundação da Ordem dos Economistas tanto no Rio de Janeiro como em São Paulo. O caráter da formação superior como bacharel em ciências econômicas, que se distanciava do ensino de contador como técnico, todavia, não distanciava esse novo profissional da origem do ensino comercial, cuja preocupação formativa era preservada para atender ao mundo dos negócios e do comércio internacional. A nova formação do economista emergiria associada ao novo mundo que seria descortinado a partir da Segunda Guerra Mundial, mas no Brasil, também pelas crescentes demandas do setor público constituídas com a centralização do Estado nos anos 1930: a expectativa era de que o economista devia ser um profissional que lidaria com novos problemas ligados ao planejamento e de condução de uma economia nacional, superando a perspectiva mais circunscrita da empresa e das atividades comerciais de um determinado setor".
} 
Soares, que institui realmente ${ }^{8}$ a Faculdade de Ciências Econômicas e Administrativas (FCEA), depois renomeada para FEA-USP (PINHO, 2006). Conforme Alice Canabrava, o projeto colocado em prática em 1946 dialogava mais com o ensino de Economia Política, fosse derivado da Faculdade de Filosofia, Ciências e Letras da USP, criada em 1934, fosse daquele tradicional ensino proveniente da Faculdade de Direito. Torna-se evidente essa característica se observarmos a formação do corpo docente do curso de Ciências Econômicas em 1946: 13 professores originários da Faculdade de Filosofia, 19 da Faculdade de Direito e outros 5 entre engenheiros e contadores. Nas palavras de Pinho:

\begin{abstract}
A FEA-USP significava, então, a resposta técnica aos novos desafios econômicos e financeiros, muitos deles imbricados em questões políticas, sociais, culturais e educacionais. Era também uma inovação que ofereceria ao mercado especialistas preparados em um ambiente de meritocracia, e sua afirmação profissional e ascensão social dependeriam, em grande parte, de sua própria competência, diferentemente dos critérios, até então predominantes, para preenchimento de vagas no funcionalismo público em expansão (PINHO, 2006, p. 11).
\end{abstract}

Ao caráter de ser a FEA predominantemente uma faculdade de "classe média" ${ }^{\text {, }}$, refletia o caráter industrial e urbano da cidade de São Paulo: tanto por conta do ensino público gratuito de segundo grau (ginásio, escolas normais, escolas técnicas) já estar amplamente difundido, como pelo fato de muitos descendentes de imigrantes (principalmente italianos) terem conseguido a sua ascensão social por meio do estudo propiciaram o caráter o qual a FEA adquiriu ${ }^{10}$. Diferentemente da Faculdade de Direito do Largo São Francisco, que até a década de 1930 havia proporcionado ao Brasil nove presidentes ${ }^{11}$, a

\footnotetext{
${ }^{8}$ Apesar da FCEA já estar prevista no Decreto 6.283 de 25 de janeiro de 1934, sai criação só se concretizou em 1946.

${ }^{9}$ Termo utilizado por Pinho, 2006.

${ }^{10}$ Nas Palavras de Canabrava (1984, p. 20): "No Estado, nas zonas pioneiras, imigrantes estrangeiros rompiam as normas tradicionais e compunham os quadros do poder legal e regional, ao mesmo tempo em que, dezenas de Escolas Normais criadas no interior em 1911, significaram a oportunidade a filhos imigrantes, de frequentar um curso relativamente rápido e profissionalizante a lhes garantir remuneração satisfatória e, para muitos, o acesso a profissões liberais, cátedras no ensino superior e outras funções de relevos." A autora continua: "O imigrante contribuiu, sob diversos aspectos, para a expansão das classes média. Várias parcelas desta população ganhavam a vida com empregados dos escritórios, que funcionavam junto às casas comerciais, bancos e indústrias; sendo 100.821 o número de estrangeiros da capital paulista em 1920, e 421.301 no Estado, alcançava 62,5\% e 52,4\%, respectivamente, a porcentagem absorvida por aqueles trabalhadores. Numerosos italianos, no primeiro quartel do século, dedicavam-se a profissões autônomas, como distribuidores de jornais, cocheiros, engraxates barbeiros, confeiteiros etc., na cidade de São Paulo." (CANABRAVA, 1984, p. 11-12)

${ }^{11}$ Dez, caso contemos o Presidente paulista Júlio Preste, eleito, mas impossibilitado de assumir devido ao golpe de 1930.
} 
FEA viria para atender a pequena burguesia incipiente e ascendente ${ }^{12}$. Delfim encaixa-se nessa descrição. Filho de imigrantes, e um exemplar das "camadas médias urbanas"13, adentra na faculdade um ano após ter concluído o segundo grau e tornando-se um técnico em contabilidade.

Ainda no começo da FEA, a primeira movimentação para estabelecer os professores da nova faculdade, foi-se contratado, a partir de março de 1946 (FEA/USP, 1946-1947, p. 130), os professores cujas cadeiras deveriam funcionar na primeira série dos cursos de Ciências Econômicas e de Ciências Contábeis e Atuariais. No segundo semestre de 1946, contrataram-se mais oito professores, totalizando 14 no total, permitindo, assim, que as cadeiras do segundo ano dos cursos pudessem ser cumpridas. De acordo com o Anuário, a forma pela qual os cursos de Ciências Econômicas e de Ciências Contábeis foram instituídos pelo Decreto-Lei 15.601 vinha recebendo inúmeras críticas, "tanto da imprensa, como especialistas em Economia, Finanças e Administração e mesmo os professores da Faculdade" (FEA/USP, 1946-1947, p. 131), pela forma como se estava distribuído os cursos.

Para tentar contornar as críticas, em 3 de Janeiro de 1947, foi convocada uma reunião dos professores para discussão de projetos de reforma. Os professores, Paul Hugon, Atilio Amatuzzi, Luiz de Freitas Bueno, Luiz Arthaud Berthet e Dorival Teixeira Vieira apresentaram propostas à diretoria. Decidiu-se desdobrar a Cadeira de Sociologia Econômica, História Econômica e Geografia Econômica em três, cada disciplina com uma Cadeira. Podemos entender que essa resolução era um indicativo de que a FEA estava a dar mais importância para esses cursos de humanidades. Inferimos que à época, ao aumentar o número de cadeiras para os cursos de ciências humanas, tentava-se distinguir a Faculdade, de uma de ensino mais técnico. Finalmente, pelo Decreto-Lei 17.344 de 28 de Junho de 1947, modificou-se as disposições do Decreto-Lei anterior, 15.601, e configurou a Faculdade como Delfim a encontrou quando entrou, em 1948. Houve, ainda, mais movimentações do colegiado Docente. Desta, destaca-se a contratação da Professora Alice Piffer Canabrava, para a Cadeira de História Econômica.

\footnotetext{
12 Tanto é assim, que nos primeiros anos foi-se concedido "bolsas de estudo" para favorecer "estudantes pobres" pela Associação Comercial, por intermédio do S.E.N.A.C. (FEA/USP, 1946-47 - p. 131).

${ }^{13}$ Para o conceito de classe média urbana ver, SAES, Decio. Classe média e Política na primeira república brasileira(1889/1930). Petropolis: vozes, 1975.
} 
Alguns professores no período já se destacavam com atribuições em cargos públicos, além dos de discentes propriamente ditos. O professor Francisco D'Auria ${ }^{14}$ integrou a Comissão responsável pelo ajuste de contas entre o estado de São Paulo, o Governo Federal, o Banco do Brasil, o Banco do Estado e o Departamento Nacional do Café. Ademais, juntamente com Dorival Teixeira Vieira ${ }^{15}$, foi indicado para fazer parte da Comissão Mista que deveriam estudar o problema dos transportes coletivos da Capital. A esses dois, somara-se Mário Vieira da cunha ${ }^{16}$, José Ignácio Benevides de Rezende ${ }^{17}$, Clodomiro Furquim de Almeida ${ }^{18}$, Luiz de Freitas Bueno ${ }^{19}$ e Geraldo Campos Moreira ${ }^{20}$, para procederem o Levantamento Econômico-Financeiro do estado de São Paulo, de acordo com o decreto 17.425 de 23 de julho de 1947.

Em 1948, quando Delfim ingressa na faculdade, podemos perceber a predominância de um ensino com muitas das características de um curso proveniente das faculdades de humanas - filosofia, geografia, história e direito - do que propriamente das exatas. A Faculdade à época contava com cinco Departamentos ${ }^{21}$.

O simples fato de serem destacadas cinco cadeiras para cursos de direito é relevante ao ponto. A faculdade apresentava-se, naquele período, como uma mistura de cursos de humanas, notadamente do direito, e com alguns tópicos de matemática. Ao analisarmos, ainda neste capítulo, os principais conteúdos das principais matérias, veremos que o ensino de ciência econômica era muito diferente do atual. As matérias compreendendo muito mais o contexto histórico, do que regendo leis universais.

De início, destaca-se que após o Decreto de 1945, a Faculdade oferecia apenas dois cursos de bacharel; o Curso de Ciências Contábeis e Atuariais, e o Curso de Ciências Econômicas. Este último tinha, em sua grade obrigatória, os seguintes cursos referentes ao primeiro ano: "Economia Política" (Cadeira XIX), "Sociologia Econômica" (Cadeira

\footnotetext{
${ }^{14}$ À época chefe do departamento, e professor responsável pela Cadeira VII Estrutura e análise de balanço.

${ }^{15}$ Responsável pela Cadeira XX, Valor e Formação dos Preços; Moeda e Crédito; Comércio Internacional e Câmbios.

${ }^{16}$ Responsável pela administração do Instituto de Administração.

${ }^{17}$ Responsável pela Cadeira XI, Sociologia Econômica.

${ }^{18}$ Responsável pela Cadeira II, Matemática Financeira e Matemática atuarial.

${ }^{19}$ Responsável pela Cadeira III, Estatística Geral e Estatística Econômica.

${ }^{20}$ Responsável pela Cadeira XII, Instituições de Direito.

${ }^{21}$ Matemática, sob a direção do Prof. Clodomiro Furquim de Almeida; departamento de Estatística, sob a direção do Prof. Luiz de Freitas Bueno; departamento de Economia, sob a direção do Prof. Dorival Teixeira Vieira; departamento de Ciência das Finanças (abrangendo Finanças das Empresas e Política Financeira); departamento de Organização e Contabilidade, sob a direção do Prof. Francisco D'Auria; e departamento de Direito, sob a direção do Prof. Geraldo de Campos Moreira.
} 
XI), "Geografia Econômica" (Cadeira IX), "Contabilidade Geral" (Cadeira V), "Complementos de Matemática; Análise Matemática" (Cadeira I), "Instituições de Direito Público" (Cadeira XII). Ao segundo ano letivo, as Cadeiras; "Valor e Formação dos Preços" (Cadeira XX), "História Econômica" (Cadeira X), "Estrutura e Análise de Balanço" (Cadeira VII), "Estatística Geral" (Cadeira III), "Instituições de Direito Privado" (Cadeira XIII), "Ciência da Administração" (Cadeira XVII). As do terceiro ano eram as que se seguem; "História das Doutrinas Econômicas" (Cadeira XIX), "Moeda e Crédito" (Cadeira XX), "Estatística Econômica" (Cadeira III). O quarto ano, matéria eletivas.

O Curso de "Economia Política"22, cujo Professor responsável era Paul Hugon, comentado por Delfim:

No início da escola, os professores eram todos autodidatas. Nós tínhamos trazido para a USP um professor francês, que era Paul Hugon, uma figura muito interessante, um professor formado na França, quer dizer, num estilo mais institucional. Ele chamava a atenção para a história do pensamento econômico. Dava um curso de Introdução à Economia, um curso francês, curto, baseado em pequenas leituras, que ele selecionava cuidadosamente e imprimia em um aparelho de gelatina, que tenho até hoje. Naquele tempo não existia nenhum livrotexto hegemônico. Samuelson apareceu em 1947 ou 1948 nos Estados Unidos e só apareceu no Brasil quando eu já estava terminando o curso, acho que saiu a tradução em 1952 ou 1953 (CIRO; COZAC; REGO, 1996, p. 91)

O prof. Hugon era Doutor em Ciências Jurídicas e Sociais pela Faculdade de Direito de Paris. O curso era extremamente focado nas diferentes instituições, nos diferentes métodos da economia e da ciência, os diferentes pensamentos econômicos - desde a antiguidade. Também, tinha um lado jurídico-político. Destaca-se o estudo das diferentes formas de propriedade privada ao longo da história desta.

O curso de "Sociologia Econômica", no qual o Professor José Ignácio Benevides de Rezende, com formação em Ciências Jurídicas pela Faculdade de Direito da USP, era o responsável pela cadeira, e Heraldo Barbuy o professor assistente. Dos principais trabalhos e conferências do professor Rezende, podemos destacar aqueles que se referem a impostos e sobre o divórcio. Esse último reflete um momento à época, mas os dois temas

\footnotetext{
${ }^{22}$ À época, Economia Política tinha a mesma conotação que adquiriu ao passar do tempo no Brasil. Hoje em dia, falar em Economia Política significa se aproximar de uma visão "mais heterodoxa, marxista". Esse novo significado que adquiriu pode ser observado ao se analisar a Sociedade de Economia Política (SEP) brasileira. Nela, encontra-se praticamente somente textos com viés marxista/heterodoxo.
} 
refletem um professor com grandes questões na área jurídica. Para ele, fazia-se mister, ao estudar a sociologia econômica, discutir o que viria a ser comunidade, sociedade e grupo social. Para essa discussão, suas principais influências são: Simmel, Herbert Spencer, Giddings, Ruth Benedict, Hans Freyer, Emilio Durkhein, Tönnies e Osborn. Esses, provavelmente, eram as referências para os tópicos de discussão no curso.

E, como Delfim apresentava o curso de sociologia: "Não é possível deixar de citar ainda um grande professor, o filósofo Heraldo Barbuy, cujas aulas aos sábados lotavam a classe. Sua insistência na Filosofia e na História davam uma iluminação surpreendente para as aulas de Sociologia” (CIRO; COZAC; REGO, 1996, p. 98).

A matéria de "Geografia Econômica", tendo por Professor responsável Dirceu Lino de Mattos, e como assistente, Latife Hamze, era composta por duas grandes partes; geografia econômica geral, por assim dizer, e a geografia econômica do Brasil. Naquelas, estudavase os diferentes tipos de biomas, as diferentes regiões e diferentes produções agrícolas em cada lugar ao redor do mundo. Nesta outra, estudava-se esses mesmos tópicos, mas divididos pelo Brasil. Neste, todos os tipos de indústrias que haviam no território nacional, e todos as produções agrícolas. Um curso realmente completo, que permitia uma grande noção da esfera produtiva, no mundo e, principalmente, no Brasil. O curso, na opinião de Dirceu de Mattos, era extremamente importante para a análise de qualquer situação. Isso, porque, "em qualquer época ou lugar, o homem - qualquer que seja a sua capacidade de trabalho ou de invenção, - tem necessidades que só a terra pode atender." (FEA/USP, 1946-1947, p. 77).

Nas palavras de Delfim: “Aliás, tínhamos um curso de Geografia dado pelo Dirceu Lino de Matos que era realmente excelente. Era um tempo em que se acreditava em alguns condicionamentos físicos mais importantes, e os livros de Huntington, que agente explorava nesse curso, eram muito interessantes" (CIRO; COZAC; REGO, 1996, p. 98). Além do Huntington, podemos destacar como referência ao professor em seu curso os autores: Bodin, Montesquieu, Ratzel, Pierre Clerget com a obra 'L'Explotation rationnelle Du Globe”, Rudmose Brown, que era professor da Universidade de Sheffield e o professor Pierre Monbeig, que esteve na USP e fez importantes trabalhos sobre a economia cafeeira e imigração no Estado de São Paulo. O curso deveria almejar mais do que ao simples estudo dos produtos em separado, preferindo-se: 
Examinar primeiro o jogo dos fatôres geográficos e humanos que intervem no fenômeno da produção das riquezas, precedendo êsse exame duma exposição geral sôbre a natureza mesma da Geografia, analisando os seus principais aspectos e problemas. Em seguida, passamos a estudar a importância dêsses fatores sôbre as diferentes modalidades e tipos de atividades econômicas (...). A professoraassistente, Latife Hamze, realizará um curso especial sôbre alguns dos principais produtos, tais como o trigo, o arroz, o petróleo, etc., (...) A cargo da referia professora-assistente ficará também o estudo de algumas das regiões brasileiras, como o Vale do S. Francisco, Vale do Rio Doce, Baixada Fluminense, Litoral Paulista, Planalto Meridional do Brasil etc (FEA/USP, 1946-1947, p. 80)

O curso de "Contabilidade Geral", cujo responsável pela cadeira era o Professor Atilio Amatuzzi e seu Professor Assistente, Hirondel Simões Luders, era muito parecido com o que é fornecido em um curso de Ciências Econômicas atual, e seu programa não demonstra ao contrário. Salienta-se, entretanto, alguns tópicos do curso daquela época que parecem ter se perdido nos dias atuais. São eles: 1. "Gênese e Desenvolvimento da Teoria"; 2. "Definições, Relações com outras Ciências e Ramos". Ainda, vale a pena ressaltar que no fim do curso fazia-se necessário uma "Monografia completa de uma emprêsa, compreendendo abertura, desenvolvimento e encerramento da escrita" (FEA/USP, 1946-1947, p. 167). O professor Atilio Amatuzzi, não recomendava o uso de manuais nos primeiros seis meses da disciplina (FEA/USP, 1946-1947, p. 94), somente depois da assimilação das doutrinas filosóficas que eram necessárias aos alunos, as quais só eram possíveis com alguns textos em italiano e em francês, e com a presença do professor em aula. Somente no segundo semestre, indicava o uso de "alguns tratados", como os de autoria de Francisco d"Auria, professor da casa, e Hermann Unior, ambos brasileiros. Também, Dumarchey, francês, e Vincenzo Mais, italiano. Somando-se a isso, os compêndios de direito deveriam ser utilizados desde o início, pois os discentes deveriam manusear "leis constitucionais, das sociedades por ações e outras, além dos códigos civil, comercial e de impostos e taxas" (FEA/USP, 1946-1947, p. 94).

A matéria "Complementos de Matemática, Análise Matemática", cujo Professor responsável pela Cadeira era Luiz Arthaud Berthet, e seus assistentes; Domingos Pizanelli e Durval Luiz Vieira de Souza, nos parece sem grandes novidades. Nele, era-se lecionado 
o equivalente as matérias "Cálculo I", "Cálculo II", geometria analítica, análise real e Matemática Financeira ${ }^{23}$.

A matéria "Instituições de Direito Público", a qual o Professor Geraldo Campos Moreira (um dos chefes de departamento à época) detinha a responsabilidade sobre a Cadeira, seu assistente Romeu Coltro, e os auxiliares de ensino: Manoel Monteiro Gondin e Geraldo Nóbrega. O Professor Geraldo Campos era Bacharel em Ciências Jurídicas e Sociais, pela Faculdade de Direito da Universidade de São Paulo. Já havia lecionado na Escola livre de Sociologia e Política de São Paulo, na Fundação Alvares Penteado além de ser Procurador do Departamento Jurídico da Prefeitura do Município de São Paulo. Seu curso, dividia-se em 36 tópicos.

O professor Geraldo de Campos dá-nos a entender que, o discurso de nação e nacionalidade era muito importante para ele. Sabia que a defesa desse conceito, não era o ideal, mas que deveria ser mantido, enquanto "a humanidade não conquistar o ideal do verdadeiro espírito de cooperação, enquanto a guerra não deixar de ser a última instância para a divergência entre as nações, cada povo, em defesa própria, tem que preservar o seu instinto de clã" (FEA/USP, 1946-1947, p. 121). ${ }^{24}$ Ademais, ao tentar definir o que seria a nacionalidade, vai contra aquelas definições que se apoiam nos conceito de que se deveria ter algo em comum (língua, etnia) dos indivíduos para considerá-los como membros de uma mesma nação.

Depois passa a discussão da constituição brasileira, e a questão de nação. Estava em discussão, na época, como se deveriam tratar os imigrantes ${ }^{25}$. Havia implícito certo nacionalismo, e um certo medo de se perder o Brasil, sua cultura e identidade. Havia um medo de se concentrar determinadas etnias em algum ponto no Brasil, que poderia vir a diminuir o espaço brasileiro. Aprovava a política Varguista, a qual chamava de patriótica,

\footnotetext{
${ }^{23}$ Para mais informações, consultar FEA/USP (1946-1947, p. 171). Havia sete tópicos no programa da matéria: 1. Teoria dos Números Reais; 2. Teoria dos Conjuntos Lineares; 3. Funções Reais de Variáveis Reais - Limite - Continuidade; 4. Derivadas e Diferenciais das Funções Reais de uma Variável Real; 5. Integrais das Funções de uma Variável Real; 6. Geometria Analítica; 7. Matemática Financeira.

${ }^{24}$ Anuário da Faculdade de Ciências Econômicas e Administrativas da Universidade de São Paulo, 194647 - p. 121

${ }^{25}$ Em 1938, houve uma mudança de lei na imigração. Antes, os imigrantes vinham sem maiores "exames sobre o assunto". Depois do decreto-lei n ${ }^{\circ} 460$ deste ano, tratou-se da imigração dirigida, que objetivava conter e "ordenar" a imigração.
} 
e levou os brasileiros a terem "apreendido o conceito realístico de nacionalidade para um Brasil cada vez maior" (FEA/USP, 1946-1947, p. 127).

Para as matérias obrigatórias lecionadas no segundo ano do curso, comecemos com a “Cadeira XX - Valor e Formação de Preços", cujo responsável era o Professor Dorival Teixeira Vieira, à época, um dos chefes de Departamento. Seus assistentes; José Fernando Martins Bonilha e Lenita Corrêa Camargo ${ }^{26}$. Os auxiliares de ensino eram: Maria José Villaça, Zélia Guimarães e Miguel Franchini Neto. A matéria, por mais que estudasse a teoria do valor marginalista, e seu conceito fundamental de utilidade para a definição de valor, estudava, também, a teoria do valor trabalho, além de historicizar o marginalismo, e o conceito de utilidade. Mesmo as leis de oferta e procura, eram um tópico a parte das formações de preços. Discutia-se a formação dos preços sob livre-concorrência, e sob monopólio.

Ainda, em um artigo intitulado "O café diante da lei da formação de preços" (, trataria sobre um tema que seria altamente estudado e debatido por Delfim alguns anos depois. Nesse artigo, já tratava sobre os efeitos de substituição do café brasileiro com outros cafés - notadamente o colombiano - e com outras bebidas (chá, cacau, bebidas alcoólicas). Esse fato, em si, já o é contestador com a crença geral (daquele período) de que, sendo inelástica a procura, poder-se-ia aumentar os preços do café brasileiro sem acarretar em graves consequências (VIEIRA, 1946-47). Refere-se, no artigo, a dois autores que estarão presentes na bibliografia de seu trabalho "O Problema do Café no Brasil" (DELFIM NETTO, [1959] 2009): Isaltino Costa, que teria feito um inquérito na Europa sobre as substituições do café brasileiro naquele continente, e que, posteriormente, escreveria "Os erros da valorização", em 1925. E, também, a Wickizer, V. D., que em um estudo na Universidade de Stanford, conclui que pequenas alterações no preço, não mudariam o hábito de tomar café; contudo, grandes alterações o fariam. Diametralmente, ao se mudar o hábito, e trocá-lo por outra bebida, pequenas alterações nos preços relativos não se fariam voltar ao consumo de café.

\footnotetext{
${ }^{26}$ A professor Lenita foi a primeira a defender uma tese de doutorado na FEA. Sua tese tinha como título: "Cooperativismo agrícola e a formação dos preços", e foi defendida em 09/10/1958. Tinha como banca os professores: Dorival Teixeira Vieira, Honório Monteiro, Roberto Pinto Souza, Ruy Aguiar da Silva Leme e Paul Hugon.
} 
Essas duas obras dos autores são citadas no livro "O Problema do café no Brasil" de Delfim. De fato, a conclusão do artigo parece muito a de Delfim naquele livro:

Não resta dúvida, porém, que alicerçar uma economia em um produto frágil, com é o café, representa um poderoso obstáculo ao progresso econômico da Nação. E nós, paulistas, que temos dado exemplo de uma atividade exuberante e cheia de empreendimentos novos, temos o dever de empregar nossas energias e os nossos recursos, não na restauração de uma riqueza passada e sempre frágil, e sim na criação de novas fontes de riqueza, capazes de suprir as lacunas deixadas pela que vai desaparecendo e de dar uma estrutura mais sólida à economia do Brasil (VIEIRA, 1946-1947, p. 62, grifos meus)

A matéria de história econômica, cuja cadeira era de responsabilidade da professora Alice Piffer Canabrava, e tinha como assistente a professora Maria Celestina Teixeira Mendes, era dividida em dois pontos gerais: a História Econômica do Brasil, de 1500 até 1914, e a História Econômica da Europa, de 1760 a 1914. Da bibliografia utilizada pela professora, destacamos, primeiramente, o livro de João Lúcio da Azevedo, "Épocas de Portugal Econômico". Esse mesmo autor, cuja temática principal é o atraso lusitano, foi grandemente usado como moldura analítica por Roberto Simonsen para entender o atraso brasileiro (BRUZZI, 2014, p. 95 et seq.). De resto, a bibliografia que se percebe era fortemente influenciada pela historiografia francesa e estadunidense ${ }^{27}$.

A Cadeira VII, Estrutura e Análise de Balanços, era de responsabilidade de Francisco D'Auria, um dos chefes de Departamento à época. A finalidade da matéria era a de fornecer habilitação ao economista "ajuizar da situação econômico-financeira de uma entidade patrimonial, diagnosticando o estado dos negócios e prognosticando seu comportamento futuro" (FEA/USP, 1946-1947, p. 88). Para essa disciplina haveria bibliografia em língua inglesas, francesa e italiana, porém estaria sendo realizado um compêndio para lecionar a matéria pelos próprios responsáveis pela Cadeira.

A matéria de Estatística Geral e Estatística Econômica, cujo professor responsável era Luiz de Freitas Bueno, graduado em engenharia elétrica pela faculdade Mackenzie e pósgraduado em Estatística Econômica pela Escola Livre de Sociologia e Política de São Paulo $^{28}$, pode ser considerada a que mais influenciou Delfim diretamente. O papel da

\footnotetext{
${ }^{27} \mathrm{O}$ artigo que Canabrava escreve para o anuário, é, muito provavelmente, um resumo de sua tese para a cadeira de professora titular: A Indústria do Açúcar nas Ilhas Inglesas e Francesas do Mar das Antilhas, 1697-1755. São Paulo: 1946, ou seja, defendida um ano antes da publicação do anuário.

${ }^{28}$ De acordo com Cavalieri e Curado (2016) a Escola Livre de Sociologia Política (ELSP) buscou, desde a época de sua formação, a contratação de cientistas políticos norte-americanos para contrapor à influência francesa da qual a USP havia tido. Essa influência da ELSP na formação de um professor de Delfim pode
} 
estatística para o autor sempre se fez muito presente em suas obras, e também, ao descrever como se deveria proceder na análise econômica. Ressaltamos, para nosso propósito, os seguintes tópicos: i) correlação, iii) indução na estatística econômica; e iii) Séries temporais. Este último, apesar de não podermos saber qual fora a exata matéria lecionada, sabemos que abarcaria os tópicos: tendências, ciclos, variações estacionais e previsões. Esta teria um tópico especial, o qual se discutiria o conceito de previsão, os elementos necessários, e os erros de previsão. O ponto da indução na estatística econômica também é muito importante para nosso autor, ao entendermos que para Delfim, seria necessário, a cada momento tentar-se ver qual modelo caberia àquela realidade, ou, melhor àquele momento determinado. ${ }^{29}$

Em 1952 Delfim Netto lecionou, como assistente de Luiz de Freitas Bueno, "Um Curso de Aperfeiçoamento em Estatística Econômica”, juntamente com outro assistente Flávio Fausto Manzoli. O curso contou com um total de 22 tópicos, distribuídos em 19 aulas incluindo uma primeira de introdução, alternando entre segundas-feiras à noite, começando às 20:30 e aos sábados, no período vespertino, com início às 14:00 horas. Esta teve início em 18 de agosto de 1952, e a última aula, em 27 de outubro de 1952. Delfim parece ter tido um papel importante para a realização do curso. Nas palavras de Luiz de Freitas Bueno:

Por outro lado, contribuiu também para a minha resolução de dar esse curso neste ano a colaboração e a crítica que me foi prestada por Delfim, recentemente formado na Faculdade e tido como um dos melhores alunos formados nesta Escola (BUENO; DELFIM NETTO; MANZOLI, 1952, p. 02)

Desses 22 tópicos, 11 seriam "aulas de revisão e complementação do curso de estatística geral e 11 de estatística econômica”. Assim, especula-se que as primeiras undécimas referir-se-iam à revisão do que porventura fosse dado no curso regular da FEA, e as

evidenciar, ainda mais, a pluralidade da faculdade: "Um dos professores que veio para a ELSP nos primeiros anos foi Horace Davis, sociólogo com doutorado pela Universidade de Columbia. Ele era responsável pela cadeira de Economia Social, na qual ensinava tópicos relacionados ao controle social. Outro norte-americano que veio para a ELSP foi Samuel Lowrie, com o doutorado obtido na mesma instituição de Davis. Os dois foram muito importantes para formação do pensamento de Simonsen, pois trouxeram dos EUA e especificamente de Columbia a abordagem eminentemente empírica da sociologia, junto com a filosofia do controle social. Depois, no final da década de 1930, veio Donald Pierson, doutor pela Universidade de Chicago e com inclinações metodológicas semelhantes."

${ }^{29}$ Em 1964, Delfim (1964) diz: “(...) os economistas desenvolveram uma técnica de pensar aplicável aos problemas econômicos. Trata-se de uma forma particular de abordagem, que na impossibilidade de deduzir leis universais que supõem a não temporalidade do sistema de referência ou de encontrar leis imanentes ao sistema, contenta-se em ensinar a escolher, em cada caso, as variáveis relevantes e a construir com elas modelos capazes de revelar as respostas do sistema às múltiplas opções dos homens". 
últimas, a uma aula de estatística econômica (ou modernamente chamado 'Econometria') que pelo visto não fazia parte do curso regular da graduação. Delfim lecionou 6 tópicos.

\subsubsection{Aspectos gerais sobre a formação de Delfim}

Pode-se evidenciar que o bacharelado em Ciências Econômicas da FEA-USP ${ }^{30}$ no período de Delfim era muito mais voltado para as matérias de humanas, do que propriamente as de exatas. A própria estrutura da faculdade, com um número muito maior de cadeiras em matérias de humanas evidenciava esse fato. Porém, ao ingressar na Bolsa de Mercadorias de São Paulo, sob tutela do professor Luiz de Freitas Bueno, da cadeira de estatística, e ao ler seus primeiros artigos na Revista dos Mercados, percebemos que seus argumentos principais passavam muito pela análise econométrica e pelo instrumental matemático.

Distingue-se, nos principais escritos para a Revista dos Mercados, algumas influências muito presentes. Para a análise do comércio internacional, salientamos Joan Robinson e Marshall. Ambos, são bibliografia básica do curso Valor e Formação dos Preços, da parte II: "Sôbre a formação dos Preços". De Robinson, temos, "Economic of imperfect competition", e de Marshall, "Princípios de Economia política", tradução portuguesa de 1946. Ambos, ainda, são o instrumento teórico que Delfim utiliza muitas vezes para entender qual política deveria ser feita em relação ao câmbio, no intuito de maximizar o crescimento econômico. A conclusão é que sempre se dependeria de determinadas elasticidades das curvas de ofertas e procuras tanto nacionais quanto internacionais, devese apreciar, ou depreciar o câmbio. O mais complicado é a questão de aplicar essa teoria ao mundo real. Para tanto, utiliza-se de estimações econométricas como forma de validar os modelos. Sempre com ressalvas, também sobre os resultados estatísticos, diz-nos se se deve utilizar os modelos para determinado problema, ou não.

Dos modelos econométricos, quando das regressões temporais, uma influência também sempre está presente. Henry Schultz, um dos fundadores da econometria (LOUÇÃ, 2011). Da própria entrevista de Delfim (CIRO; COZAC; REGO, 1996, p. 92), sabemos que a análise de séries de tempos era matéria da cadeira de estatística do prof. Luiz de Freitas Bueno. Contudo, na matéria de estatísticas, o autor estudado (CIRO; COZAC; REGO, 1996, p. 92), era Harold Davis, "The Theory of Econometrics [1941]" e "The

\footnotetext{
${ }^{30}$ À época FCEA.
} 
Analysis of Economic Time Series [1941]”. Enquanto esse autor não é mencionado em nenhum artigo de Delfim, Schultz, por sua vez, é muito utilizado. Sabendo que, temporalmente, Delfim se forma em 1952, e nesse mesmo ano publica seu primeiro artigo na Revista dos Mercados, o qual cita o livro de Henry Schultz. Ademais, na bibliografia do curso de Teoria e Formação de Preços, encontramos referência do livro, "The Law and measurement of demand", H. Schultz. Assim como também encontramos a referência para o livro de H. Davis.

Para a matéria "Moeda e crédito", temos na bibliografia o compêndio de Eugênio Gudin, "Princípios de economia monetária", que para Delfim:

Em Economia Brasileira, pode-se considerar Gudin um clássico, o Princípios de Economia Monetária. Um livro que pôs a gente em contato com Wicksell, mais ainda com Wicksteed. (...) Eu era socialista Fabiano e Wicksteed foi um exemplo clássico. Ele demonstra a falsidade da teoria do valor trabalho. Gudin, na verdade, abriu um campo de leitura. (CIRO; COZAC; REGO, 1996, p. 93-94)

Dois outros livros que merecem destaque nessa matéria, é o livro de Keynes, "A treatise on Money”. E, de Irving Fisher, "L'illusion de La monnaie stable". Nessa mesma matéria, havia uma grande discussão sobre os tipos de sistemas monetários; do monetarismo ouro, do monetarismo de prata, do bimetalismo, e sobre os diferentes sistemas fiduciários. Sabendo disso, podemos inferir, com alguma certeza, que seu terceiro e quarto artigos (DELFIM NETTO, 1953a e DELFIM NETTO, 1953b) para a Revista dos Mercados, no qual trava uma grande discussão acerca dos diferentes sistemas monetários, provém, em grande parte, de uma síntese de suas aulas de moeda e crédito. As matérias de "Valor e Formação dos Preços e Moeda e crédito", podem ser consideradas análogas àquelas que ficaram depois conhecidas como microeconomia. É marcante a diferença que existe na forma como Delfim as recebeu, e na forma pela qual se transformaram em um curso de economia atual.

Delfim pode ser considerado como um economista muito sui generis. Pois, em sua formação recebeu instrução de muitos tipos diferentes de influências; a matemática, ensinada por matemáticos. A estatística, por estatísticos. A história, por historiadores. A geografia econômica, por geógrafos etc. Dessa forma, a síntese de todos esses cursos, dados no "original", síntese feita pelo aluno, é o que podemos chamar de "educação do bacharel Delfim”. A educação é sempre utilizada para o entendimento da realidade 
brasileira, a qual, de alguma forma resultaria no curso "Economia Brasileira", cadeira a qual Delfim se tornaria responsável nos anos 1960.

Logo após a sua saída pela faculdade, essa síntese começa a diminuir, e os chamados "livro-textos" são marcantes nesse sentido. Os livros, tão comentados por Delfim, Turroni e Samuelson ${ }^{31}$, exemplificam a transformação do curso de economia em um curso muito mais orientado pela adoção dos chamados "livros-textos". Assim, percebemos uma maior homogeneização das disciplinas. O curso de economia deixa de ser um somatório de partes para serem montadas como um quebra-cabeças, para passarem a ser, cada vez mais, um somatório de "ajuntamentos". Cada vez menos lecionadas por professores de diferentes áreas, para serem lecionadas, de maneira crescente, por professores economistas, e com formações, por serem feitas com livros textos (muitas vezes os mesmos), muito parecidas. A pluralidade, que em grande parte foi muito importante para a formação do maior economista egresso da FEA/USP, com professores de diferentes formações, passa a ser, com o passar dos anos, mudada, tendo-se economistas de diferentes vertentes como professores.

Esperou-se conseguir mostrar quais foram as principais influências acadêmicas de Delfim durante sua graduação. Em primeiro lugar, as matérias as quais lhe foram lecionadas na graduação. Não só havia uma predominância dos cursos de humanas, com uma forte influência do direito e da filosofia, como também em todos os cursos - inclusive os de contabilidade, matemática e estatística, cujos docentes eram especialistas em suas respectivas áreas, e não economistas de formação. Em segundo lugar, suas influências: sabemos que fora com Luiz de Freitas Bueno que começou sua carreira profissional. Ademais, o artigo de Dorival Teixeira Vieira sobre o café é relevante ao mostrar que o

\footnotetext{
${ }^{31} \mathrm{Na}$ entrevista que Delfim concede, ele diz: "O livro que mais me influenciou nessa época foi o de Bresciani Turroni, Curso de Economia Política[1960]. O primeiro volume cuidava de formação de preço, teoria do valor, e o segundo, da parte da moeda, de comércio internacional. Claro que tudo isso desapareceu depois que apareceu Samuelson. Ele produziu um estrago de tal natureza que as pessoas acreditaram que toda a Economia vinha de Cambridge, Estados Unidos. No tempo que eu estudava seguia-se a linha de Cambridge, Inglaterra." CIRO, B. ; COZAC, L. F. L.; REGO, J. M. Conversas com Economistas Brasileiros São Paulo: Editora 34,1996. (p. 91, grifos meus). Pode-se comparar esse processo descrito por Delfim de sua própria experiência, com aquele descrito por Backhouse (1998, p. 85): “'“In the 1920s and 1930s, U.S. economics was pluralistic in the sense that no one approach dominated the profession. Classical economists (Frank Taussig at Harvard) and institutionalists (John Commons at Wisconsin and Wesley Clair Mitchell and John Maurice Clark at Columbia) flourished alongside neoclassical economists (Irving Fisher at Yale) and Marshallians (Edward Chamberlin at Harvard). Some individuals defied classification (Frank Knight at Iowa and then at Chicago). By 1960, all this had changed, and neoclassical economics, or at least the neoclassical synthesis of Paul Samuelson's textbook, was unquestionably dominant. Heterodox approaches still existed, but they were clearly in a subordinate position."
} 
problema do café no Brasil era algo que há muito tempo se estava discutindo, e que todas as discussões se ajudavam e se amontoavam. Dorival Teixeira Vieira, inclusive, já salienta a grande necessidade de se pensar na maximização da renda provinda do café no longo prazo, e não no curto. Ponto central que será retomado por Delfim posteriormente. Assim, pode-se entender a tese de livre docência de como o resultado de um gigante "apoiado sobre ombros de gigantes". Em terceiro lugar, a FEA - em um primeiro momento - não era protagonista no debate político-econômico do Brasil. Pode-se afirmar que galgaria seu espaço tendo Delfim como protagonista principal. Em quarto, Delfim não só estava a presenciar a mudança do curso de economia no Brasil, como uma própria mudança do curso de economia no mundo. Em quinto lugar, Delfim auxiliou a construir uma nova economia que estava por vir e que iria dominar quase que todos os cursos de ciências econômicas no Brasil.

\subsection{O método da economia para Delfim}

Em 1958, Delfim escreve um livro (nunca publicado) no qual ele expõe qual seria a sua percepção sobre o método que deveria ser utilizado para se fazer economia. Este deveria ser o mesmo método das outras ciências. Não era perfeito, longe disso, mas era o único possível. A partir dele, seria criada uma ciência "frágil", pois não se buscaria a verdade irrefutável; mas sim, uma ciência que deveria ser necessariamente mutável, pois, caso contrário, não seria ciência, e sim, fé. Esta ciência deveria estar a serviço da humanidade, e não, deveria se automatizar e ganhar corpo descolado dos problemas reais, porque a ciência só seria útil enquanto ajudasse a sociedade a entender observações da realidade, e não fazer com que as observações da realidade "se encaixassem" na ciência já existente. Este método, outrossim, não seria nada mais do que "aquele que pessoas comuns utilizam ao se deparar com problemas no dia a dia "como o conserto de um defeito no automóvel"" (DELFIM NETTO, 1958, p. 04). Em resumo, a forma de se fazer ciência para Delfim seria uma tentativa de adequação da indução (observação da realidade) com a dedução. Sempre em busca de se impedir que hipóteses se tornassem dogmas.

Haveria dois tipos de ciência, as formais (que consistiriam na lógica e na matemática) e as teórico-empíricas, as quais descreveriam e preveriam os acontecimentos. Um modelo formulado nestas últimas só faria sentido se estas estivessem sido construídas em respaldo com um teste de adequação da realidade. O método científico, para Delfim, que caberia a todas as ciências empíricas, seria dividido em três partes; 1. A observação com um objetivo, (com utilização da estatística e da história); 2. A formulação de generalizações 
ou hipóteses de trabalho (2.1 a partir destas se deduzira consequências observáveis); 3 . Verificação, feita a partir da história e/ou estatística. Contudo, esse método, deve ser entendido, nos parece, como método "chão de fábrica", pois algumas qualificações são feitas. A ciência não seria de forma alguma neutra, porque o pesquisador já partiria necessariamente de hipóteses iniciais; e por isso, no fundo, toda ciência teria um grau de arbitrariedade; e nem seria uma fórmula mágica, "mas um processo de sistematização da pesquisa, de forma que não pode transformar um medíocre num gênio" (DELFIM NETTO, 1958, p. 30). “A realização das grandes hipóteses de trabalho é papel do gênio", porque existiria a diferença entre o pesquisador "de chão de fábrica" e o gênio, e só esse último teria a "intuição" necessária para a criação de grandes hipóteses, que seriam as que revolucionariam a ciência ${ }^{32}$. Contudo, o pesquisador medíocre também teria seu espaço dentro da ciência, porque a “incorporação ao 'corpus' da ciência só se faz através de um exame crítico realizado através do método científico" (DELFIM NETTO, 1958, p. 30). Esse método teria surgido com Galileu, mas também seria reflexo das obras de Bacon e Descartes, de onde a ciência teria deixado de ser contemplativa, e passaria a ser "ação para o domínio do mundo" (DELFIM NETTO, 1958, p. 31).

O problema da indução não é deixado de lado. É patente para Delfim que uma hipótese “não poder ser provada pela experiência" (DELFIM NETTO, 1958, p. 39, grifos no original), o que já o afasta de algum "positivismo ingênuo". Ele afirma que nada teria sido feito para solucionar o "buraco aberto por Hume na indução e na causalidade" (DELFIM NETTO, 1958, p. 50). O método científico, portanto, estaria seriamente limitado, pois se basearia em dois frágeis pilares: "a indução amplificadora" e o "princípio de causalidade". Como forma de superar esses problemas lógicos, apoia-se em Bertrand Russel (1931), e afirma que a ciência só cresceu porque "alguns espíritos" tiveram "a coragem de postular respostas positivas a essas questões metafísicas e epistemológicas", caso contrário, ela não teria seguido em frente (DELFIM NETTO, 1958, p. 51). Ou seja, não só a ciência não seria a busca pela verdade (pois ela é apenas a melhor adequação as

\footnotetext{
${ }^{32}$ Apesar de Delfim não entrar muito em detalhes sobre o que seria essa intuição necessária ao cientista, é difícil falar o que se trata exatamente. Muitas vezes chega a parecer quase uma noção metafísica que seria necessária à ciência. Como se nota nessa passagem de um estudo que trata sobre a noção de intuição e empiria na ciência: "Then Einstein shook the very foundations of physical theory by a brillant and successful modification of the cherished concepts of space and time. a modification which depended not on empirical discovery but upon application of an intuitional requirement." $\mathrm{E}$ conclui: "The conclusion I wish to draw from these remarks is that knowledge depends as much upon intuition as it does upon extrospection and logic; and that these aspects are interdependent. I have hoped to make you aware of the implication that the nature of the rational act is much more complicated than heretofore supposed and that the simplistic views of cognition must irrevocably be discarded." (SMITH, s/d)
} 
observações do período), como também, ela teve de "atropelar" a lógica, e encontrar soluções práticas (mesmo que falaciosas) para permitir que o conhecimento expandisse.

As hipóteses devem, por outro lado, ser significantes no sentido de Samuelson (1953) (exploraremos melhor esse ponto na continuidade do texto). Além disso, é importante notar que não se abandona uma hipótese até se ter uma outra, melhor (que explicaria mais coisas), pois, entre outros motivos, a própria rejeição das hipóteses tem um parâmetro de probabilidade e de "julgamento de valor" (DELFIM NETTO, 1958, p. 49). Delfim, ora afirma que seriam as hipóteses do modelo (ou suas deduções) que deveria ser "assentadas na realidade", ora, que o modelo deva se adequar para explicar (ou mesmo prever) a realidade, e portanto, não dizendo nada sobre o realismo das hipóteses desse modelo. Todavia, como, em momentos diferentes, ele fala que os dois devem estar assentados, entendemos que assim o seja, indo no sentido contrário da perspectiva Friedmaniana de metodologia da ciência, a qual estaria mais preocupada com a capacidade de previsibilidade da teoria, e menos com a relevância das hipóteses (FRIEDMAN, 1953). ${ }^{33}$ Não se proporia o transporte dos modelos das ciências naturais para as sociais, mas, sim, o "método de pensar", que seria não relegar às ciências sociais um modelo "in abstracto" o qual não poderia ser confrontado com a realidade. Estes modelos "in abstracto", que não teriam possibilidade de serem confrontados com a realidade, "eram estéreis" (DELFIM NETTO, 1958, p. 18).

Para livrar a economia de uma série de dogmas que até hoje ainda tem foros de ciência; para tirar-lhe o aspecto de um bonito exercício intelectual mas irrelevante para a explicação dos fenômenos econômicos é preciso utilizar aquele método de pensar, que não é mais do que a união indissolúvel da observação, teorização e verificação (DELFIM NETTO, 1958, p. 19)

A ciência da economia se teria consolidado com a transformação do mundo "quando se generalizou o espírito capitalista de que nos fala Sombart" (DELFIM NETTO, 1958, p. 21-22, grifos meus). Quando a sociedade estática, "cujos maiores valores eram a segurança e a tranquilidade", passou a ser dinâmica, "dominada pelo espírito capitalista", teria surgido a necessidade de descrever e explicar esse novo mundo. Por isso que as contribuições de Aristóteles - à ciência econômica - teriam sido limitadas: pelo mundo no qual ele vivia, não seria já uma sociedade que tivesse o "espírito capitalista"

\footnotetext{
${ }^{33}$ Há uma celeuma sobre qual seria a melhor interpretação do trabalho seminal de Friedman de 1953, e a "resposta" que Samuelson deu no seu, também, seminal artigo de 1963. Contudo, a interpretação relevante para este trabalho é que Delfim fala em realismo das hipóteses e em realismo do modelo, nos parecendo distanciar da percepção do que seria o método relevante na economia para Friedman. Para mais informações cf. Boland (2000), Boland (2003), Wong (1973), Barbosa et Alii (1994) e Mogin (1991).
} 
generalizado, assim, limitando a ciência econômica ${ }^{34}$. Por isso, para Delfim, se tornaria impossível de separar a ciência econômica de uma ciência empírica, pois, para ele, a economia esteve associada "aos problemas que tiveram de ser resolvidos por determinadas sociedades". Dessa forma, ela teria sido sempre empírica, porque "esteve sempre sujeita à confirmação ou refutação da realidade" (DELFIM NETTO, 1958, p. 23). A ciência econômica teria surgida a partir duas escolas opostas, i) a de $\mathrm{Mill}^{35}$, dedutivista, a qual seria decorrente de uma crença em leis naturais semelhantes às da mecânica "regendo os fenômenos econômicos" (DELFIM NETTO, 1958, p. 24); ii) e a escola histórica alemã, que teria uma concepção de ciência "essencialmente ligada a cada sociedade", e privilegiaria o método indutivo. Essas duas noções teriam se fundido, estabelecendo, para Delfim, o que se entende por lei econômica.

A ciência econômica seria, então, um "conjunto de proposições sistematicamente deduzidas, de um conjunto de noções primeiras" as quais seriam deduzidas pelos sentidos. E, "ao contrário do que ocorre nas ciências naturais" essas noções primeiras dependeriam do tempo e do espaço, e, portanto, os postulados da teoria econômica deveriam sempre se alterar, e, assim, "nesse sentido, o conhecimento da realidade econômica está em contínua reelaboração" (DELFIM NETTO, 1958, p. 24). Para esclarecer este ponto, Delfim traz ainda as considerações de N. Keynes:

\footnotetext{
'The progress of society does not merely affect the solution of old economic relating to complex problems of Money, credit, international trade, and the like, that can apply only to advanced economic societies. In relation to earlier states of society these doctrines are not so much false as irrelevant' (KEYNES, 1904, p. 304, grifos meus ${ }^{36}$ ).
}

Para complementar esse ponto, o autor se vale do filho de Neville, "Maynard Keynes", o qual teria sido o melhor economista do século XXI para Delfim (até 1958, momento que

\footnotetext{
${ }^{34}$ Interessante cotejar esta passagem de Delfim, ao descrever a limitação de Aristóteles em compreender a economia estar sujeita a limitação da sociedade na qual o grande filósofo viveu, com Marx no Capital, ainda no primeiro capítulo, quando este diz: "O fato de que nas formas dos valores das mercadorias todos os trabalhos são expressos como trabalho humano igual e, desse modo, como dotados do mesmo valor é algo que Aristóteles não podia deduzir da própria forma de valor, posto que a sociedade grega se baseava no trabalho escravo e, por conseguinte, tinha como base natural a desigualdade entre os homens e suas forças de trabalho. O segredo da expressão do valor, a igualdade e equivalência de todos os trabalhos porque e na medida em que são trabalho humano em geral, só pode ser decifrado quando o conceito de igualdade humana já possui a fixidez de um preconceito popular. Mas isso só é possível numa sociedade em que a forma-mercadoria [Warenform] é a forma universal do produto do trabalho e, portanto, também a relação entre os homens como possuidores de mercadorias é a relação social dominante. O gênio de Aristóteles brilha precisamente em sua descoberta de uma relação de igualdade na expressão de valor das mercadorias. Foi apenas a limitação histórica da sociedade em que ele vivia que o impediu de descobrir em que "na verdade" consiste essa relação de igualdade. (MARX, 2011)

${ }^{35}$ E também "Senior, Cairnes e outros escritores ingleses" (DELFIM NETTO, 1958, p. 24)

${ }^{36}$ Apud DELFIM NETTO, 1958, p. 25.
} 
Delfim escreve este texto). Para ele a teoria econômica não é um "corpo de conclusões definidas", mas, sim, um método, um aparato da mente, uma técnica de pensar, e não, uma doutrina.

Para Delfim, existiriam três tipos de leis econômicas; 1. As leis "a priori", "simples definições ou tautologias"; 2. As leis deduzidas de "hipóteses de trabalho convenientes", as quais exemplifica dizendo que seriam iguais às de equilíbrio deduzidas a partir de hipóteses de maximização do lucro total; e 3. As leis empíricas, "que são generalizações das observações que nos chegam diretamente pelos sentidos", e dando exemplo, cita as “curvas de procura de Schultz e a Função de Produção de Cobb-Dougls”. Para Delfim, o primeiro tipo de lei seria comum tanto nas ciências naturais quanto na economia. Com relação ao segundo tipo, a princípio a diferença também não existiria, contudo, "o instrumento estatístico moderno foi construído sobre hipóteses que se verificam mais precisamente no mundo físico" (DELFIM NETTO, 1958, p. 27), fazendo, então, com que a economia fosse uma ciência ainda mais frágil do que como Delfim se refere como as ciências naturais; nota-se que a ciência natural não é algo tão rígido, ou tão perto da verdade assim. A ciência natural também é suscetível a mudanças. Delfim elogia o modelo de Ptolomeu (geocêntrico) ao explicar que este descrevia melhor as observações da época, ao contrário do de Aristarcoo (heliocêntrico), o qual não descrevia tão bem, mesmo sendo o héliocentrismo claramente o modelo mais correto para Delfim. Esse argumento está longe de ser uma defesa do geocentrismo, mas, ao contrário, uma defesa que a ciência deva explicar as observações do momento. Pois teria sido somente com Kepler, que o sistema heliocêntrico se mostraria satisfatória às novas gamas de observações que surgiram. Para Delfim, não só a as ciências naturais, mas também, as sociais, não poderiam ser vistas como reflexo de "leis naturais", como se fossem condenadas a um determinismo deístico. O erro teria sido, por exemplo, considerar que sendo o universo criado por um ser perfeito, impondo que a órbita dos planetas fosse circular, e contradizer as observações da época. Situação análoga seria encontrada na economia, ao se a tratar como dogmática, fosse essa partir de leis divinas, criadas por uma entidade, ou não. Se se tentasse "obrigar" alguma observação ser de forma a se adequar à visão de mundo (fosse ela criada a partir de uma deidade, ou não), estar-se-ia incorrendo no mesmo erro que teria obrigado a observar trajetórias perfeitamente circulares dos planetas. Então o desafio para Delfim seria trazer às ciências humanas hipóteses que 
fossem passíveis de serem confirmadas. Fosse uma hipótese que pudesse ser confirmada diretamente, ou uma hipótese de nível superior, cujas consequências fossem passíveis de confirmação. Para Delfim, ao aproximar as ciências sociais das ciências naturais, ele não chega a dar mais exatidão àquelas, mas, pelo outro lado, dar menos certeza a estas pois seriam geradas a partir de leis estatísticas (exemplifica com a segunda lei da termodinâmica); claro que, com um "porém" às ciências humanas, pois a estatística (como visto) não funcionaria tão bem para as ciências humanas como para as naturais.

"Dessa forma, as leis empíricas tanto da física como da economia se exprimem por proposições do tipo 'se... então..., num determinado nível de probabilidade' de forma que a diferença entre elas é muito mais de grau do que de natureza" (DELFIM NETTO, 1958, p. 27-28). Contudo, há, ainda, uma diferença a mais entre as ciências física - nas quais o homem é o espectador (pois mesmo entendendo a gravidade causa uma queda, não se é possível impedi-la, apenas utiliza em prol) - e, na economia, no qual o homem seria não só espectador, mas também, “ator”. Pois as causas seriam passíveis de mudança (inflação, desemprego etc), ao contrário do que ocorreria nas ciências naturais. "O fato de o homem aprender por experiência, portanto, tem um significado completamente diferente na economia e na física, por exemplo, porque uma mesma causa pode não produzir o mesmo efeito"37 (DELFIM NETTO, 1958, p. 28).

Uma ciência econômica que não questionasse seus postulados seria inútil. Exemplifica com a persistência histórica que a economia teve em afirmar que não haveria uma possibilidade de existir uma insuficiência da demanda efetiva que pudesse manter o volume de emprego em determinado nível: “continuou sendo negada, mesmo quando a experiência mostrava a sua realidade, porque contrariava um postulado da economia clássica"38 (DELFIM NETTO, 1958, p. 53). A questão das observações da realidade serem as principais condutoras da ciência é muito enfatizada, e em cada momento ele se

\footnotetext{
${ }^{37}$ Esse argumento (da diferença entre as ciências físicas e as sociais, pois o "homem aprende por experiência) é muito comum na fala de Delfim até os dias de hoje, podendo ser observado em várias entrevistas que ele dá sobre o assunto. Conferir, e.g., Ciro, Cozac, Rego (1996, p. 105), onde Delfim diz: "Em um regime ideal as pessoas são pontos, e se comportam como pontos. Por que a Economia se distingue realmente das ciências fortes? É que na Economia o átomo aprende. Você já imaginou uma Física em que o átomo aprendesse? Eu sempre brinco, o automóvel não ia existir; o átomo está lá na rua, andando, de repente, schuup, é chupado para dentro de um motor, é empurrado por um êmbolo, lá em cima recebe uma faísca, booff, e aquilo explode, sai pelo escapamento todo queimado, se arrebentando, nunca mais! Quando depois o átomo vir um automóvel, não entra mais. Na Economia é assim. É por isso que hoje as expectativas, a credibilidade e a experiência têm um papel relevante. Na Economia só enganamos o átomo uma vez, na segunda vez o átomo nos engana".

${ }^{38}$ Comentário com clara influência Keynesiana, o qual introduziu o conceito de desemprego involuntário.
} 
utiliza de um exemplo diferente. Da mesma forma, diz ele, que a "teoria construída para explicar a taxa de juro na idade média" seria quase completamente irrelevante para explicar o fenômeno naquele momento em que escreve, também o seriam a teoria clássica do comércio internacional e a teoria da empresa. Ele não cansa de frisar que, estar teorias não seriam erradas, seriam, apenas, irrelevantes. Por silogismo, como o critério da teoria é apenas a sua validade prática, utilizá-las não só seria inútil, como também, retardador para a solução dos problemas.

O método científico é descrito por Delfim com minúcias. É importante destacar aqui como ele acreditava que se daria o "enriquecimento" do "corpo das ciências". Delfim não acredita que a utilização da matemática garanta "um grau maior de certeza às teorias econômica" (DELFIM NETTO, 1958, p. 41), ela seria apenas um instrumento que permitiria a confrontação das 'ideias' com a "realidade”. "É esta [a realidade] a suprema corte que julga as proposições da teoria que se não conseguem satisfazer num grau apreciável aquela adequação, são inapelavelmente abandonadas” (DELFIM NETTO, 1958$, p. 41$)^{39}$.

É, então, com essa metodologia em mente, que Delfim critica explicitamente (como exposto no capítulo quarto dessa dissertação) as teses de "não-responsividade" dos preços da agricultura no Brasil na década de 1960. E, implicitamente, é falta de observância dos resultados clássicos da teoria do comércio internacional e da teoria quantitativa da moeda, que fará com que Delfim se utilize de outras abordagens para o entendimento dos problemas do comércio internacional e da inflação. Este critério de demarcação de ciência de Samuelson, no qual Delfim afirma basear-se, tem bastante proximidade com aquela de Popper, autor que viria a ser um argumento de autoridade importante para Delfim em seus escritos da década de 1960. Esta proximidade da demarcação científica entre os dois autores é notável, e.g., Boland (2003) se refere a “demarcação de Popper-Samuelson” em clara menção de que não haveria distinção entre as duas. Em muitos textos de Delfim, este os inicia com epígrafes de Popper $^{40}$. No texto feito para criticar o diagnóstico sobre a agricultura no PAEG, por exemplo, começa com a citação de Popper:

\footnotetext{
${ }^{39}$ Delfim, em outro texto comentando o ensino da teoria econômica, em edição que apresenta a reforma curricular da FCEA de 1964, mantém a mesma opinião sobre a metodologia. Acredita que o economista se diferencia por uma "técnica de pensar" multidisciplinar que cabe ao economista escolher as variáveis em cada caso que sejam relevantes para aquele momento temporal e histórico. (DELFIM NETTO, 1964).

40 Também em um texto intitulado "Nota Sobre a Estimação da Relação Produto/Capital com os dados da contabilidade Nacional" Delfim cita Popper: "Reason works by Trial and error. We invent our myths and
} 
'The game of science is, in principle, without end. He who decides one day that scientific statements do not call for any further test, and that they can be regarded as finally verified, retires from the game' (POPPER, K. The Logic of Scientific Discovery, [1959] 2005, p. 32) ${ }^{41}$

Essa citação entra como arma para Delfim revelar o seu ponto: a ciência deveria se curvar à realidade, se assim não o fizesse, aquela estaria por perpetuar uma crença, alguma ideia sem embasamento na realidade, que seria daquela maneira que Delfim se apercebia sobre as teses a respeito da agricultura no Brasil. Contudo, não se pode dizer que o conceito de ciência econômica e metodologia aprendida por Delfim teria vindo dos EUA. Muito provavelmente, os instrumentos de análise estatística econométrica, sim, vieram de lá, como é perceptível ao se ler "O Problema do Café no Brasil” (DELFIM NETTO, [1959] 2009), onde todas suas referências ao discutir os principais métodos de cálculo de elasticidades são provenientes dos Estados Unidos. Isso faz bastante sentido, pois fora especialmente após a segunda guerra que a ciência econômica produzida lá passou a ter grande influência para o resto do mundo. Para Klein et Alli (2013) foi no período pós Segunda Guerra Mundial que o processo de matematização e formalização da ciência econômica tomou uma guinada definitiva. Esse tipo de racionalidade - a combinação do formalismo, com o cálculo econômico, a otimização, e o "raciocínio analógico" (KLEIN, et al. 2013, p. 03) - fora incentivada com "prodigioso financiamento governamental" estadunidense, instituições militares e a RAND corporation ${ }^{42}$. Ainda de acordo com os autores, essa racionalidade fora desenvolvida com o propósito precípuo de se ganharem guerras, o que demostra a ciência não como contemplativa, mas, por outro lado, como um instrumento que se pretende transformador da realidade. Assim, Ana Maria Bianchi (2013-2014), em harmonia com essa interpretação, diz que as pesquisas mais recentes sobre a matematização na economia mostram que a origem desse processo se dá durante a $2^{\circ}$ Guerra Mundial, nos Estados Unidos, ganhando força na Guerra Fria com "participação ativa dos órgãos de segurança nacional, sob cujo patrocínio diferentes modelos matemáticos foram concebidos, inicialmente para fins bélicos" (BIANCHI, 2013-2014, p.76) ${ }^{43}$. Contudo, mais do que a matematização e formalização da ciência

our theories and we try them out: we try to see how far they take us" Popper, Conjecture and Refutations. Apud DELFIM NETTO, 1965b, p. 01.

${ }^{41}$ Apud DELFIM NETTO, s/d, p. 279.

${ }^{42}$ A RAND corporation, Research and Development foi criada em 1946 por financiamento do governo dos EUA, e privado. Na década de 1950, ela foi responsável por informar os governo estadunidense em uma variedade de questões. Entre essas, destacam-se a corrida espacial, as confrontações nucleares com a URSS e o projeto de "mutually assured destruction", que preconizava o uso automático de destruição total do outro país, caso esse o atacasse.

${ }^{43}$ Goodwin (1998, p. 64) afirma sobre o assunto: ““"The utility function had become simple; the sole 
econômica, entendemos, que o mais importante desse processo, foi a guinada da mudança do uso da economia. De uma ciência "contemplativa" (utilizando-se os termos de Delfim (1958, p. 31) para uma ciência que pudesse interferir realmente na política, e assim, e principalmente por esse motivo, a econometria que é tão desenvolvida nos EUA, toma corpo e passa a ser bastante estudada por Delfim. Dois pontos podem ser ressaltodas, a partir de Loureiro (1997, p. 3), para a explicação da ascensão da contratação de economistas no mando público ${ }^{44}$; 1) a crise de 1929 , porque os economistas teriam passado a ser "vistos como os portadores de instrumentos capazes de produzir resultados práticos na economia" e; 2) A utilização de economistas para se defender de ataques políticos de cunho econômico em um debate político. Os economistas servindo, aproximadamente, como um assessor do político no debate. Contudo, parece-nos que para economistas que quisessem "planejar a sociedade" era fundamental o uso de dados, e a análise e processamento deles era o passo esperado. Chow (2001, p. 631), ao explicar a ligação entre econometria e política econômica, diz: "Statistics is a set of method for making decisions under uncertainty. Economic policies are decisions made under uncertainty. Accordingly, statistics is useful for the formulation of economic policy."

Mesmo sendo com essa ciência (e com esse novo tipo de economista) que pensamos que Delfim queria se comunicar, buscando a interlocução com autores de lá, não acreditamos que a influência tenha vindo de lá. Fosse metodológica, fosse de suas principais ideias. Apesar de citar Samuelson como referência ao se referir como deveria ser uma "hipótese", cita-o por meio do livro texto "Foundations" (SAMUELSON, 1953), e não por seu texto clássico sobre metodologia de 1963, no qual se posiciona e discorda sobre a metodologia na economia de Friedman (1953), e abre as portas para todo um debate a partir desses textos. No momento em que Delfim escreve seu livro sobre metodologia (1958) não indica que lera (e no seu texto nada indica o contrário ${ }^{45}$ ) o texto de Friedman (1953), e não poderia, também, ter lido o texto de Samuelson somente escrito e publicado alguns

objective was to win the war. Optimization problems abounded, from how to maximize the production of high-octane fuel with a given feed stock to where best to locate machine guns in a bunker. Kindleberger (1991) and Galbraith (1981) both have written eloquently about the exhilaration of applying their analytic tools to the questions of where and when to drop bombs on the enemy."

${ }^{44}$ Fazendo ressalvas que esses motivos não esgotam a totalidade de motivos existentes para tal.

${ }^{45}$ Inclusive Delfim se refere à classificação de "Economia Positiva" de Neville Keynes dizendo que seria esta que ele estaria estudando, a mesma que Friedman também diz estar estudando (inclusive é parte do título do artigo de Friedman (1953)), contudo Delfim não faz nenhuma referência a Friedman. O que suscita duas possíveis possibilidades, a mais simples, que Delfim não havia lido (e menos provável, porque foi um artigo que causou "bastante rebuliço"), e, uma segunda, que simplesmente Delfim - para não discordar diretamente dele - não o citou. 
anos depois (1963). Mesmo o que Delfim traz de Samuelson é muito pouco esclarecedor, pois o próprio não se prende muito ao assunto ${ }^{46}$ :

By a meaningful theorem I mean simply a hypothesis about data could conceivably be refuted If only under Ideal conditions. A meaningful theorem may be false. It may be valid but of trivial importance. Its validity may be Indeterminate, and practically difficult or Impossible to determine. Thus with existing data, it may be impossible to check upon the hypothesis that the demand for salt is of elasticity. But it is meaningful because under ideal circumstances an experiment could be devised whereby one could hope to refute the hypothesis. The statement that if demand were inelastic, an increase in price would raise total revenue is not a meaningful theorem in this sense. It Implies no hypothesis - certainly not even that a demand exists which is Inelastic - and is true simply by definition. It may possibly have had a certain "psychological" usefulness in helping economists ask the right questions of the facts, but even here I have some doubts (SAMUELSON, [1947] 1971, p. 0405).

A impressão que temos é que Delfim conseguiu amarrar o geist do espírito econômico daquele momento, que seria aquilo que se tornaria uma das visões dominantes sobre a metodologia científica na economia, mesmo sem ser influenciado por aqueles considerados os grandes influenciadores desse processo. Visão esta reafirmada pela descrição sobre o método científico feita por Delfim, na qual ele se aferra às ideias de diferentes filósofos/economistas para tentar construir seu ponto sobre metodologia. Dessa forma, não teria como ele ter sido influenciado pela metodologia proveniente dos EUA de forma direta, pois, mesmo Popper, é muito pouco provável que ele o lera antes da década de 1960. Dito isso, pensamos que a sua grande influência tenha sido o economista italiano Bresciani Turroni. Em especial nos "primeiros escritos" de Delfim da década de 1950, nos quais a referência a aquele economista se fazia muito presente.

Turroni foi um economista italiano do começo do século XIX, que ficou famoso por duas grandes obras: "Curso de Economia Política", citada bastante por Delfim como sua grande influência; e, também, por um estudo sobre o desenvolvimento da economia e sociedade alemã durante o período de 1914-23, o qual culminara numa massiva desvalorização do câmbio e num acelerado processo de inflação. Segundo Schumpeter, o

\footnotetext{
${ }^{46}$ Outra passagem também interessante do livro de Samuelson ([1947] 1971, p. 142) sobre o método econômico é: "Often nothing more is stated than the conclusion that people behave as they behave, a theorem which has no empirical implications, since it contains no hypothesis and is consistent with all conceivable behavior, while refutable by none. Nevertheless, as we shall see, the modern utility theory with all its qualifications is not in a technical sense meaningless hypothesis which places definite restrictions upon demand functions and price-quantity data, these could be refuted or verified under ideal observational conditions".
} 
pensamento econômico de uma sorte de economistas italianos daquela geração de Turroni não era segundo o de ninguém (SCHUMPETER, [1954] 2006, p. 822).

Em artigo publicado em 1910, pode-se observar bem a noção de metodologia científica para Turroni, a qual era, também, uma defesa da combinação do método dedutivo com o indutivo. Assim como Delfim, ele também defende o uso de um só método científico para as "ciências sociais" e para as "ciências da natureza" (BRECIANI-TURRONI, 1910, p. 271), com o uso de leis científicas. Contudo, essas "leis", seriam "limitadas no tempo e espaço" (BRECIANI-TURRONI, 1910, p. 288) e deveriam sempre serem postas à prova,

\begin{abstract}
A ciência moderna (...) reconhece que a experiência é última instancia que decide inapelavelmente se as nossas deduções deram uma descrição adequada dos fatos ou se são apenas uma pura exercitação lógica (BRECIANITURRONI, 1910, p. 275).
\end{abstract}

O seu método constituiria em recorrer ao método dedutivo (utilizando-se da abstração), em separar as causas importantes e em estudar nelas os efeitos, posteriormente, em as recompor e, em chegar, dessa maneira, para a reconstituição das condições concretas do real. A estatística seria importante nesse processo, podendo oferecer uma resposta "ao menos parcial" ao problema da incapacidade do método experimental nas ciências humanas. Bini (1992) afirma que essa perspectiva de método e ciência em Turroni só poderia significar que não poderia existir em economia "um conhecimento que seja tanto exaustivo e definitivo" (BINI, 1992, p. 47), implicando que a economia (ou as leis econômicas) estaria sempre em constante transição, e mudando historicamente. Seria fundamental conseguir e valorizar o maior número de contribuições, para não se poder "por uma fidúcia ilimitada em um sistema teórico, à custa de uma outra" (BINI, 1992, p. 47).

Interessante que, em concordância com Bini (1992), se por um lado haveria uma grande influência do "Positivismo de John Stuart Mill", Turroni representaria um movimento na Itália - identificado com muito dos pesquisadores do começo do século - que trazia sim o empirismo como necessidade à ciência, mas que por outro lado, questionava o Positivismo como forma de se fazer ciência. Esse movimento intelectual ficou conhecido como "convencionalismo", o qual teve como seus principais representantes Poincaré e Duhem. Este "movimento intelectual" - longe de ser perfeitamente homogêneo ${ }^{47}$ - por

\footnotetext{
${ }^{47}$ É destacada a diferença de concepção de metodologia científica para Poincaré e Duhem, contudo isso não altera o fator "macro" dos dois autores. Eles tinham diferenças grandes entre si, mas pequenas o suficiente para serem tidos como ambos pertencentes a uma mesma "escola convencionalista". Conferir Chiappin (2015) e Hernández (2002).
} 
sua vez é tido por alguns autores como influenciador (OLIVEIRA, 2005), ou, pelo menos, antecipador (CHIAPPIN; LEISTER, 2015) dos critérios científicos elaborados posteriormente por Popper.

Assim, entendemos que se Delfim encontrou em Popper na década de 1960 uma referência intelectual, isso se deu pela percepção deste autor de que o conhecimento científico seria mutável e constante (sempre em cotejamento com a realidade), e, também, em Samuelson, pelo seu critério de demarcação da ciência. Assim argumenta-se que Delfim obteve influências, em especial Turroni, que já o haveriam encaminhado na direção daqueles autores. A leitura de Popper e Samuelson deve ter sido para Delfim, menos uma descoberta, e, muito mais, um encontro gratificante de quem ouve de outros aquilo que pensava. Estes autores - inquestionáveis pelo seu posicionamento político ${ }^{48}$ serviram para construir uma metodologia que permitisse a Delfim ir contra algumas das teses/hipóteses/dogmas da economia, que - em sintonia com a descrição da ciência econômica - para ele não teriam mais serventia.

\footnotetext{
${ }^{48} \mathrm{Em}$ um mundo marcado pela guerra fria, frisamos que esses autores poderiam ser vistos como insuspeitos de serem apoiadores da União Soviética. Apesar de que, mesmo Samuelson teria passado por uma certa descriminação dentro dos EUA, como possível disseminador de ideias perigosamente marxistas: Paul Samuelson's successful new introductory economics textbook was widely vilified for the dangerous Keynesian ideas it contained. A commentator in the rightwing Educational Reviewer asked: "Now if (1) Marx is communistic, (2) Keynes is partly Marxian, and (3) Samuelson is Keynesian, what does that make Samuelson and others like him? The answer is clear: Samuelson and the others are mostly part Marxian socialist or communist in their theories" (MACIVER, 1955, p. 128 apud GOODWIN, 1998, p. 58).
} 


\section{Capítulo 2 - O amadurecimento como economista}

\section{1 Os escritos da década de 1950.}

Os textos escritos durante a década de 1950 por Delfim, analisados nessa seção, são todos artigos publicados em revistas, com graus de "cientificidade" que variam. Uns muito mais “científicos", enquanto outros, de caráter mais jornalístico, se aproximando da linguagem vernácula comum, discutindo temas mais cotidianos e menos teóricos. A análise, então, buscou uma interpretação coerente das ideias do autor em estudo, tentando reunir diferentes artigos ao redor de alguns tópicos que nos pareceu mais interessante à exposição. Destacam-se os temas que aparecem com mais frequência para Delfim: o algodão, o comércio internacional, e a inflação. Por outro lado, se esses temas são os mais discutidos, o que está por detrás dessa discussão é o tópico da possibilidade do aumento das entradas de divisas estrangeiras, a qual era tida como condição fundamental para a continuidade do "desenvolvimento econômico" no Brasil.

Três revistas foram analisadas, a Revista dos Mercados, publicada pela Bolsa de Mercadorias de São Paulo BMSP; a Revista de Ciências Econômicas (RCE), editada pelo Ordem dos Economistas de São Paulo; e a Digesto Econômico, editada pela Associação Comercial de São Paulo (ASCP). Totalizando 24 artigos. Logo após se formar, Delfim fora lecionar na BMSP, e, por essa instituição, escreveu seus primeiros artigos acadêmicos. Seu primeiro texto nessa revista é escrito em 1952, e, seu último, em 1955. Nota-se que são artigos com um instrumental mais economicista; não só mais matemático, como também, com mais jargões econômicos. Ademais, em muitos momentos, consegue-se distinguir claramente influências diretas de sua formação na FEA. Em 1957, é lançado seu primeiro artigo pela Digesto econômico, e, seu último analisado, em dezembro de 1959. A revista Digesto Econômico, começou a circular em dezembro de 1944 editada pela Associação Comercial de São Paulo (ASCP). Os primeiros artigos de Delfim saíram em 1957. Tal revista, assim como a RCE, tinha um perfil mais prestigiado no meio acadêmico brasileiro. Figuras importantes da economia brasileira, como Eugênio Gudin, Celso Furtado ${ }^{49}$, Roberto Campos e Octávio Bulhões

\footnotetext{
${ }^{49}$ Ambos expoentes de "escolas" com pensamentos opostos à época. Gudin, à frente da EPGE e o que se poderia chamar de pensamento liberal, e Furtado, da CEPAL, escola que ficou conhecida com "Estruturalista". Para uma exposição resumida sobre o assunto, cf. Loureiro Lima (1994, p. 39-40)
} 
publicavam com frequência artigos nela. O contato de Delfim com a ASCP fora fundamental por dois principais motivos: a biblioteca da Associação era excelente, "talvez a melhor biblioteca econômica fora da USP" (COELHO, 2007, p. 425). Além do contato com quadros de empresários. "Geralmente de origem européia, especialistas em comércio, bancos, moeda, açúcar, café etc.” (COELHO, 2007, p. 421).

A Ordem dos Economistas, responsável pela publicação da RCE, havia feito algumas mudanças desde a sua fundação até o período em que a história dela se enlaça com a trajetória de Delfim. Da época de sua fundação, datada de 1935 (SAES; CYTRYNOWICZ, 2001), a maioria de seus membros havia realizado o curso comercial e seguido "naturalmente" em direção ao de administração e finanças, ou ainda, contabilistas. Isso de fato era de se esperar, pois a Ordem veio para representar uma profissão nova, a do economista, cujos primeiros bacharéis nessa área haviam se formado em 1934 (SAES; CYTRYNOWICZ, 2001, p. 22). Como uma das tentativas de fortalecerse perante a sociedade no debate econômico, lança, em 1939, a RCE. Naquele momento, a primeira revista de caráter "científico", especializada em economia. No primeiro artigo da revista, o presidente da Ordem, à época, Horácio Berlinck afirmou o que ele compreendia ser o campo da ciência econômica: "particularmente a organização estatística e coletiva da indústria econômica, as propriedades gerais dos fenômenos econômicos, deduzidos dos fenômenos sociais, e, finalmente, o progresso econômico" (SAES; CYTRYNOWICZ, 2001, p. 28). Na mesma época, em 1939, a Ordem, juntamente com o Departamento de Cultura da Prefeitura do Município de São Paulo lançam a campanha do "padrão de vida", cujo objetivo era conseguir-se estabelecer critérios para um salário mínimo. Em 1940, com a legislação sindical da época de Vargas, a Ordem assume a função de sindicato. Somente em 1948, refundar-se-ia a Ordem dos Economistas como entidade desvinculada dos Sindicatos. Contudo, mantendo os mesmos presidentes, diretores e “os mesmos propósitos” entre as duas instituições.

A RCE sofreu algumas atribulações ao longo desse período. Em 1940, a publicação da revista era de regularidade bimestral, e, em 1944, chegou a ser mensal. Com uma decisão do Departamento de Imprensa e Propaganda, de proibir a vinculação de anúncios a revistas de sindicatos, teve-se de transferir a propriedade da RCE para Herrmann Junior ${ }^{50}$,

\footnotetext{
${ }^{50}$ Hermman Junior, formado em perito-contador pela Escola de Comércio Álvares Penteado, foi Secretário de Finanças Públicas na cidade de São Paulo, além de outros cargos públicos. Publicou alguns livros importantes nas áreas de contabilidade e administração de empresas.
} 
diretor da revista. Nos anos 1950, muda-se a composição dos membros da ordem. Passam-se a vigorar, de modo crescente, o número de bacharéis economistas propriamente ditos, e de rarear, os membros contabilistas, ou de outras áreas. Nos debates da RCE, esse fato se faz presente. Começa-se a pôr em discussão temas como desenvolvimento econômico como uma tarefa que caberia ao governo de planejar (SAES; CYTRYNOWICZ, 2001, p.61-62). Debatedores presentes na RCE ao tema do planejamento econômico, foram, entre outros, Eugenio Gudin, Celso Furtado, Raul Prebisch, Dias Carneiro, e um pouco mais tarde, Roberto Campos, Alexandre Kafka e Delfim Netto.

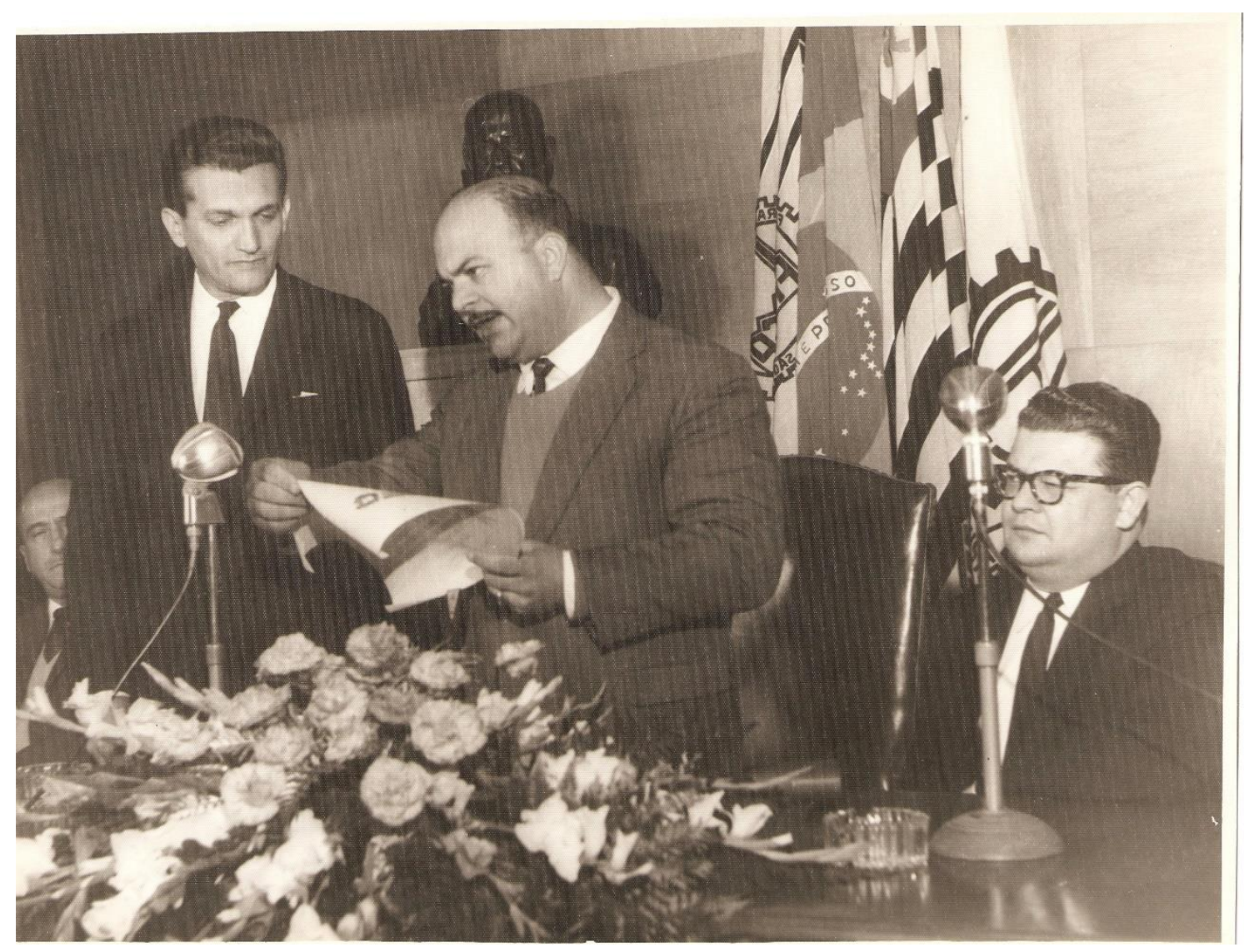

(Delfim Netto entregando prêmio de Economista do Ano para Celso Furtado pela Ordem dos Economistas)

Além disso, como pano de fundo das discussões econômicas de Delfim, deve ter sempre em mente o mundo político/econômico que acontecia no Brasil. Os primeiros escritos de Delfim fazem menores menções ao cenário político, no qual Getúlio Vargas era presidente, do que quando Juscelino Kubitschek tomou o cargo, indicando um aumento do descontentamento dele com o mando político do país. A crítica de um governo "populista" que tomava atitudes com pouco pensar, somente para agradar no curto prazo 
e se manter no poder, sem maiores preocupações com um planejamento de longo prazo também é, cada vez mais, associada ao governo de JK. Este tinha como bandeira o auspicioso programa de metas, como uma tentativa de resposta aos problemas apontados pela Comissão Brasil Estados Unidos (CMBEU) (LAFER, 1970, p. 35). Ligado ao programa, tivemos um aumento da renda nacional e do crescimento industrial, concomitantemente a um aumento do endividamento, dos gastos públicos e da inflação. A indústria de substituição de importações - entre elas a automobilística que fora diretamente atacada no segundo artigo da Revista de Ciências Econômicas e era bandeira importante do Governo JK (DELFIM NETTO, 1957b) - é duramente criticada, pois para Delfim, esta forma de industrialização agravava o balanço de pagamentos e a inflação. Em especial porque certas indústrias e certos industriais, protegidos pelo governo, estariam acomodados, sempre fazendo aumentos de preços para manterem sua participação na renda, ajudando, assim, a agravar o aperto no balanço de pagamentos e a inflação no Brasil.

No começo da década de 1950, foi sentido no país um grave aperto no balanço de pagamentos, a primeira crise cambial "séria" após o término da Segunda Guerra mundial. Nesse sentido, o algodão representava, para Delfim, a melhor alternativa no momento: ele permitiria a entrada de divisas externas, em um mercado o qual o Brasil não era determinante do preço (como no café), e, dessa forma, poderia aumentar as vendas e, portanto, a entrada de divisas.

\section{$2.2 \mathrm{O}$ algodão}

\subsubsection{O Algodão como alternativa ao café}

A BMSP é de suma importância na trajetória de Delfim, pois o produto principal comerciado nele era o algodão (pois havia uma bolsa especial para o café, à época, localizada em Santos), produto esse que fará parte fundamental da argumentação de Delfim em seus primeiros escritos. Essa instituição fora fundada em 26 de outubro de 1917 (BMSP, 1987) por um grupo de comerciantes liderados por João Telles da Silva Lobo. Da primeira comissão da bolsa, faziam parte, além de seu presidente, Cassio Muniz de Souza, Jorge de Moraes Barros, Luiz Pinto de Queiroz, José Ferreira de Oliveira, M. R. de Souza Nazareth e Felix Bandeira Júnior. Estes personagens:

Representavam a força emergente da economia urbana num país duramente castigado pela crise da economia exportadora de café e de açúcar. Era inadiável, portanto, modernizar e diversificar o mercado 
interno. A Bolsa funcionaria como uma importante alavanca para acelerar esse processo - um instrumento do mercado para expandir e modernizar o próprio mercado (BMSP, 1987, p. 20).

Os principais objetivos da Bolsa, então de sua criação, seriam a "classificação" e "catalogação dos produtos que eram nela comercializados", e oferecer proteção contra as “inevitáveis oscilações de preços no futuro". De tal forma a incentivar a comercialização de bens no país, em especial o algodão.

Além disso, a indústria vinha ganhando força, e a têxtil era a motriz nesse início de industrialização em um país tradicionalmente agrário, e com fortes raízes no campo. $\mathrm{O}$ algodão era uma alternativa para atender os centros de produção interna e externamente. Para as tecelagens nacionais, era-se muito custoso ficar esperando as oscilações de mercado, que poderiam aumentar de um dia para a noite os preços da matéria prima, e tornar não lucrativa suas atividades. No período de guerras mundiais, além das dificuldades inerentes da rubiácea ${ }^{51}$, o café perde muito mercado externo, abrindo espaço para o plantio alternativo do algodão, que viria a atender o mercado interno e ser uma alternativa a exportação. No começo dos anos 30, os tempos de bonança da BMSP parecem que não terminariam, e junto ao interventor do estado de São Paulo, Cardozo de Mello, conseguem um empréstimo para construir uma nova, e portentosa sede de 14 andares (BMSP, 1987, p. 38)

Depois da derrocada 1929/30, aos poucos, a BMSP se recupera.

A decadência do café havia funcionado como um formidável impulso à policultura em São Paulo. O algodão ressurge como força redobrada nos anos 30. Pouco a pouco, ele amplia seu espaço, ocupando no final da década uma área equivalente à dos cafezais (BMSP, 1987, p. 38).

Como Mostra Villela e Suzigan ([1973] 2001), no período de 1930 até 1945, o café perde muito espaço na agricultura brasileira, possibilitando que outras culturas tomassem seu lugar, diversificando o plantio brasileiro. Diz Furtado ([1959] 2007, p. 277): "Boa parte desses capitais, não há dúvida, a própria agricultura de exportação se encarregou de absorver em outros setores, particularmente o do algodão"52. Como pode-se observar com a tabela "Porcentagens Médias dos Períodos", o algodão foi o produto que mais cresceu em área cultivada durante o período. Mas não só este, como também muitos outros

\footnotetext{
${ }^{51}$ Ponto melhor discutido no capítulo 3 dessa dissertação.

${ }^{52}$ Contudo, Furtado ([1959] 2007, p. 278) continua: "Contudo, o fator dinâmico principal, nos anos que se seguem à crise, passa a ser, sem nenhuma dúvida, o mercado interno".
} 
produtos tiveram seu plantio aumentado, com destaque para o feijão e a mandioca, produtos claramente utilizados para o consumo interno. Percebe-se, também, a correlação entre a criação da BMSP e o fomento da cultura algodoeira. Em 1924, a "Escola de Classificação Algodoeira da BMSP” começou as atividades, e, no ano seguinte, 1925, a "estação experimental de Piracicaba" foi criada para a seleção de sementes de algodão. Técnicos brasileiros viajaram até os EUA para receber treinamento especializado e dirigir a estação. Em 1932, o Estado deu à Bolsa o poder de impor multa para os comerciantes desonestos que burlavam a qualidade mínima do algodão imposta pela BMSP que seriam transacionados lá. A BMSP determinara o comprimento da fibra que poderia ser negociada (de 22 a 34 milímetro), fiscalizava os leilões, o regulamento de entrega do algodão comprado a prazo, e criara um sistema de cotações.

O estado de São Paulo, em reconhecimento ao trabalho da BMSP, nomeou-a classificadora oficial de algodão. Garantindo, assim, uma qualidade de exportação alta, graças, também, ao Instituto Agronômico de Campinas (IAC), pois se havia sido criado uma seção algodoeira em 1922 lá, e, em 1931 começaram-se a separar as fibras da melhor qualidade para serem distribuídas para os agricultores (PELÁEZ, 1971a). A BMSP também estreitou o relacionamento entre as demandas dos consumidores estrangeiros e com os produtores brasileiros, ajustando a qualidade aos gostos dos clientes. Além disso, pode-se considerar, que este "programa de desenvolvimento" foi muito importante, contando com "ingredientes de programas modernos de assistência técnica" como desenvolvimento de centros de pesquisa, transmissão de tecnologias, conhecimentos financeiros, especialização no exterior e desenvolvimento do mercado. A partir de 1930, a BMSP organizou seu próprio departamento agrícola, para "instruir os agricultores no preparo da terra, erosão do solo, prevenção de pragas, etc" (PELÁEZ, 1971a, p. 178). A Escola de Classificação do Algodão da BMSP foi muito bem-sucedida em seu proposito sendo parte do treinamento dos alunos o envio deles a fábricas, estações experimentais e fazendas. "Não raro os visitantes contribuíam para a solução de numerosos problemas relacionados com a produção e o comércio algodoeiro" (PELÁEZ, 1971a, p. 176). A escola também passou a admitir alunos internacionais da américa latina. 


\begin{tabular}{|lrrr|}
\hline & \multicolumn{3}{c|}{ Porcentagens Médias dos Períodos } \\
\cline { 2 - 4 } Produtos & $1931 / 32$ & $1937 / 38$ & $1940 / 41$ \\
\hline Algodão & 6,5 & 16,9 & 18,7 \\
Arroz & 7,3 & 6,9 & 7,2 \\
Cacau & 1,5 & 1,3 & 1,8 \\
Café & 35,8 & 25,5 & 18,7 \\
Cana-de- & & & \\
açucar & 3,2 & 3,4 & 4,3 \\
Feijão & 6,1 & 7,2 & 7,5 \\
Fumo & 0,8 & 0,7 & 0,7 \\
Mandioca & 2,4 & 3,2 & 4,5 \\
Milho & 32,2 & 29,9 & 30,5 \\
Trigo & 1,4 & 1,2 & 1,8 \\
Outros & 2,8 & 3,8 & 4,3 \\
Total & 100 & 100 & 100 \\
Fonte: VILLELA e SUZIGAN $([1973] 2001)$ & & \\
\hline
\end{tabular}




\begin{tabular}{|c|c|c|c|c|}
\hline \multicolumn{5}{|c|}{ Brasil - Consumo Aparente de Algodão (1911-45) (Milhões de Metros) } \\
\hline \multirow[t]{2}{*}{ Anos } & A & $\mathrm{B}$ & $\mathrm{C}$ & $\mathrm{D}=\mathrm{A}+\mathrm{B}-\mathrm{C}$ \\
\hline & Produção Nacional & Importações & Exportações & Consumo Aparente \\
\hline 1911 & 379 & 84,5 & 0 & 463,5 \\
\hline 1912 & 400 & 69,6 & 0 & 469,6 \\
\hline 1913 & 385 & 59,4 & 0 & 444,4 \\
\hline 1914 & 314 & 22,4 & 0 & 336,4 \\
\hline 1915 & 471 & 17,5 & 0 & 488,5 \\
\hline 1916 & 474 & 30 & 0 & 504 \\
\hline 1917 & 548 & 24,8 & 0,1 & 572,7 \\
\hline 1918 & 494 & 28,4 & 0,7 & 521,7 \\
\hline 1919 & 584 & 22,4 & 0,7 & 605,7 \\
\hline 1920 & 587 & 29,4 & 0,8 & 615,6 \\
\hline 1921 & 552 & 12,2 & 3,3 & 560,9 \\
\hline 1922 & 627 & 19 & 4,7 & 641,3 \\
\hline 1923 & $940 *$ & 23,7 & 4,8 & 958,9 \\
\hline 1924 & 580 & 35,3 & 0,3 & 615 \\
\hline 1925 & 536 & 44,3 & 0,1 & 580,2 \\
\hline 1926 & 539 & 44,3 & 0,1 & 583,2 \\
\hline 1927 & 594 & 43,8 & 0,1 & 637,7 \\
\hline 1928 & 582 & 50,3 & 0,1 & 632,2 \\
\hline 1929 & 478 & 29,9 & 0,1 & 507,8 \\
\hline 1930 & 476 & 8,1 & 0 & 484,1 \\
\hline 1931 & 634 & 2,7 & 1,7 & 635 \\
\hline 1932 & 631 & 2,3 & 0,4 & 632,9 \\
\hline 1933 & 639 & 4,8 & 0,5 & 643,3 \\
\hline 1934 & 716 & 2,9 & 2,6 & 716,3 \\
\hline 1935 & 753 & 2,1 & 1,3 & 753,8 \\
\hline 1936 & 915 & 2,4 & 1,9 & 915,5 \\
\hline 1937 & 964 & 2,7 & 4,1 & 962,6 \\
\hline 1938 & 910 & 2,9 & 1,5 & 911,4 \\
\hline 1939 & 894 & 3,3 & 12 & 885,3 \\
\hline 1940 & 840 & 8,8 & 24 & 824,8 \\
\hline 1941 & 990 & 4,6 & 56 & 938,6 \\
\hline 1942 & 1069 & 0,9 & 154 & 915,9 \\
\hline 1943 & 1414 & 4,2 & 160 & 1258,2 \\
\hline 1944 & 1383 & 1,2 & 121 & 1263,2 \\
\hline 1945 & 1065 & 1 & 146 & 920 \\
\hline
\end{tabular}

Nesse período, a Bolsa almejou fomentar a exportação do algodão. Em seus esforços, envia mostruários do produto para Bolsas ao redor do mundo. O resultado é visível; em 1930 as exportações de algodão em rama chegavam a um pouco mais de 30 mil toneladas, alcançam, no final da década, 323 mil toneladas. Um aumento surpreendente de mais de 
1000\%. Com o começo da segunda Grande Guerra, as indústrias têxtis ganham enorme força e alavancam a produção do algodão. Os contratos de algodão na BMSP acompanham essa tendência altista.

À época, a BMSP já realizava um trabalho de assistir aos produtores e comerciantes do algodão com serviços. Contava com um departamento de rádio, para transmitir um programa diário, "A hora da Bolsa", que divulgava as principais notícias sobre melhoramentos agrícolas e possíveis pragas. Nesses últimos quesitos, a BMSP contava com uma "Escola de Classificação de Algodão" donde saíram especialistas anualmente, treinados para a cultura do algodão por um "Departamento Agrícola", que pesquisava e divulgava novas técnicas e tecnologias para o plantio. Um dos grandes avanços resultado dessas iniciativas algodoeiras foi o de resolver um dos maiores problemas para o aproveitamento do algodão na produção interna entre 1918 a 1933. O algodão produzido não podia ser utilizado na indústria devido ao pequeno comprimento das fibras. Por meio dos estudos e esforços das instituições, conseguiu-se aumentar o tamanho das fibras, de 22 a 26 milímetros para 28 milímetros durante a década de 1930.

Em 1927, a Bolsa de Mercadorias de São Paulo, em coadjuvação com o Ministério da Agricultura e com a Secretaria da Agricultura de São Paulo, resolveu entrar no campo das atividades agrícolas a fim de cooperar com aquelas entidades oficiais para a solução do problema da produção de boas sementes, em escala comercial, pela propagação das variedades originadas em estabelecimentos de seleção. Ao lado dos estudos realizados no Instituto Agronômico de Campinas e na Estação Experimental de Piracicaba, a Bolsa de Mercadorias de São Paulo estabeleceu, entre os lavradores das várias zonas algodoeiras do Estado, campos de cooperação, onde se pudessem introduzir medidas práticas de alcance econômico e onde se pudessem formar bons núcleos de seleção de sementes para futuras distribuições aos lavradores das vizinhanças, a preços módicos e com a mais absoluta garantia de genuidade das sementes. (...) As constantes pesquisas do Instituto Agronômico de Campinas melhoraram extraordinariamente as características genéticas do algodão paulista. Abandonou-se o algodão de fibra máxima de $24 \mathrm{~mm}$. para, gradativamente, se atingir uma produção algodoeira extraordinariamente uniforme de $28-30 \mathrm{~mm}$., o que é altamente recomendável para as fibras da malvácea produzida neste Estado. (...) $\mathrm{O}$ algodão paulista, (...), é considerado um dos mais uniformes do mundo (DELFIM NETTO; HAUSNER; STILMAN, 1954, p. 12-13). 


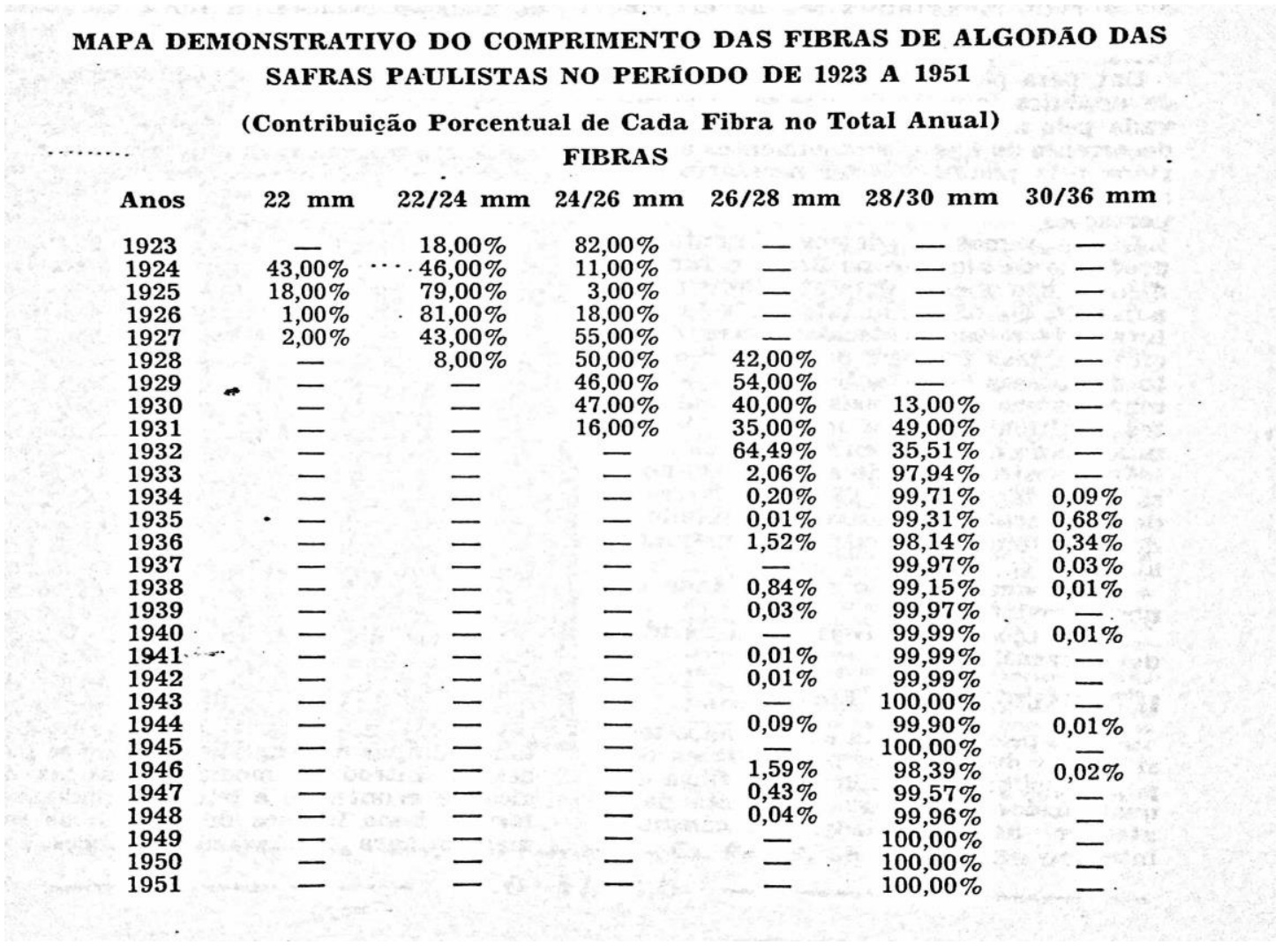

Fonte: Delfim Netto, Hausner, Stilman (1954, p. 12)

Assim, se no começo o algodão ganhara muito com a sustentação do preço por parte dos EUA, posteriormente, a produção foi aumentando em qualidade e em produtividade, tornando o fornecimento interno possível, fomentando as indústrias têxteis, e tornandoas competitivas. Além disso, como afirmam Villela e Suzigan ([1973] 2001, p. 207), a safra paulista de 1934, que foi de 90 mil toneladas, teria sido apenas de 81 mil toneladas, caso se tivessem utilizados de sementes da safra de 1923. Em apenas nove anos conseguiu-se um aumento muito grande de produtividade apenas com seleções de semente. Contudo, após a $2^{\circ}$ Guerra Mundial, o preço do café, muito devido às políticas de defesa do governo brasileiro, voltou a crescer, e o café tornou a ganhar espaço no plantio em substituição a produção do algodão. Muito por isso, a Bolsa, sob os auspícios do novo presidente, começa a editar uma revista bimestral, intitulada "Revista dos Mercados", em que a intenção era a de apresentar

Estudos, em artigos especializados, sob responsabilidade dos seus autores ou colaboradores, não sòmente assuntos econômicos e técnicos sôbre produção, comércio, indústria e finanças, como os atuais serviços informativos do "Boletim" e de interesse para as classes produtoras em geral (BMSP. 1950, p. 01). 
Intencionava-se, dessa forma, fomentar novamente a produção do algodão. Também, esse movimento era uma reação à queda da produção de algodão, a BMSP convoca a chamada “Comissão Especial do Algodão", em maio de 1950, com a intenção

Inadiável de se alertarem as classes produtoras e os poderes públicos, estaduais e federais, no sentido de se pôr um dique a essa quéda e, com medidas praticas e urgentes, se procurar reerguimento de sua cultura, uma das bases fundamentais da economia de São Paulo e do País (BMSP, 1950, p. 01).

Era querido, de alguma forma, deslocar as atenções que o governo voltara a dispensar ao café, para voltar a dispensá-la ao algodão. Especialmente em 1950, quando a cultura passou por um ano especialmente ruim:

Duas fases distintas caracterizam a estação algodoeira do Estado de S. Paulo, ainda em curso: a primeira, de grande otimismo, baseado na possibilidade de safra abundante, em vista da forte distribuição de sementes aos lavradores. A germinação correra bem até fins de janeiro ou mesmo começos de fevereiro deste ano e poucas eram as vozes discordantes sobre o volume da colheita em perspectiva. (...) De repente, o cenário se transfigurou. Já se havia observado que o plantio da safra fora consideravelmente retardado, em vista da prolongada estiagem de 1949, a qual só permitiu as semeaduras, na maioria das zonas, em fins ou meados de novembro, quando já se consideram praticamente fora de época e, por conseguinte, sujeitas a eventual queda de produtividade. Posteriormente, nos primeiros meses do ano, o regime de chuvas, inesperadamente desfavorável, com fortes enxurradas e até trombas dágua, seguido de grande elevação da temperatura, não somente prejudicou o melhor desenvolvimento das lavouras, como permitiu a erupção de pragas do algodoeiro, em quantidade nunca imaginadas. (...) Começou, então, o início da segunda etapa: a do pessimismo (BMSP, 1950, p. 58-59).

Mesmo essa etapa de pessimismo poderia logo ser superada, pois em 1954 as perspectivas mundiais para o algodão já voltariam a se recuperar, tendo, naquele ano, um aumento de $50 \%$ da demanda mundial em relação ao ano anterior (MOVIMENTO DO ALGODÃO, 1954, p. 05). Seria, então, tudo uma questão de se manter nesse caminho, ou voltar a cultura do café.

Sabe-se que a única forma de se estar menos dependente das intempéries naturais, nos cultivos agrícolas, é o aumento de técnicas na produção. Apesar do já grande esforço da BMSP nesse sentido, ela percebe que esse esforço deverá aumentar, e se deverá divulgar melhor os estudos nos laboratórios dela realizados. Além disso, o mercado agrícola tem certas peculiaridades que tornam extremamente instáveis os seus preços. No caso do algodão, ressalta-se a importância que tem a safra paulista ser inversa a dos países 
setentrionais, maiores consumidores do produto. Somando-se às confusões do câmbio, inflação e crédito, era de extrema importância estudos de cunhos 'técnicos-econômicos' numa tentativa de minimizar-se os riscos. É nessa ótica que entenderemos os escritos de Delfim para a revista deste órgão, que começam no ano de 1952, e terminam, três anos depois, em 1955. O Prof. Luiz de Freitas Bueno, começara a escrever pouco tempo antes, e é a ele quem pensamos que se deve creditar a ida de Delfim àquela instituição.

\subsubsection{O Algodão como resposta para o prosseguimento do desenvolvimento econômico}

Para Delfim, a cultura do algodão beneficiou-se muito da cultura do café de outrora, pois esta já garantiu àquela toda uma estrutura, a qual o autor se refere como a uma "capacidade de organização" adquirida com a outra cultura e; também, teria sido devido à queda da lucratividade do café, que teria possibilitado uma troca entre as culturas (DELFIM NETTO, 1952a, p. 23). Boa parte, para Delfim, da queda da lucratividade do café foi devido as próprias políticas de valorização do café (por parte do governo brasileiro) as quais teriam financiado - ao menos em parte - a cafeicultura em outros países, tornando-os nossos concorrentes. O café já é visto como um impeditivo ao desenvolvimento por Delfim já em 1952, ao afirmar que "o café que drenava grande parte de nossos fatores de produção" (DELFIM NETTO, 1952a, p. 23), e, ao "drenar", impedia que esses fatores fossem utilizados em outras atividades, que não acabassem sendo destruídas por excesso de produção regularmente.

Mesmo assim, Delfim - como é mostrado no capítulo quarto dessa dissertação, ao se discutir o tema "planejamento" - não acredita na capacidade da agricultura como força transformadora da sociedade, pois, entre outros motivos, seria ela muito instável. "Dada a pequena resistência econômica que caracteriza a produção agrícola” (DELFIM NETTO, 1953d, p. 13), principalmente "pela tendência à deterioração a que estão sujeitos certos produtos da terra" (DELFIM NETTO, 1953d, p. 13). Um dos problemas a discutir também como exercício econométrico - é se o preço do algodão sofreria uma "variação estacional", i.e., se o preço teria seu valor aumentado (ou diminuído) em alguma parte do ano, devido as colheitas serem restringidas a poucos meses. Em suas palavras:

Assim, no caso do algodão, a oferta não é uniforme durante o ano, mas particularmente durante uma época do ano. (...) quando as previsões são de uma pequena colheita. Aqui a pressão da procura faz com que os preços comecem a se elevar antes dela entrar no mercado. É preciso notar que as previsões devem alterar principalmente os preços dos negócios a termo e, por meio destes, agir sobre os preços no disponível (DELFIM NETTO, 1952a, p. 24-25). 
Delfim tenta confirmar se existe ou não o processo de "Variação Estacional". Para tanto, utiliza-se dos valores mensais - deflacionados - dos preços do algodão "em pluma tipo 5", no disponível em São Paulo -CR\$/Arroba e com o método razões em cadeia ( Link Relative $)^{53}$. Para não apenas ver os dados como indiferentes do contexto, faz uma retrospectiva sucinta dos anos 1940-1950, e tenta explicar - junto aos dados - por qual motivo em determinado período existe alguma porcentagem que sai do esperado:

Já vimos que em 1950 a safra americana foi bastante reduzida, o que levou a uma limitação das exportações, aumentando consideravelmente o preço internacional do produto. No último trimestre o início da guerra da Coreia produziu novo aumento (DELFIM NETTO, 1952a, p. 30).

Para comprovar que o método das "Razões em Cadeia" não depende dos preços estarem deflacionados para a verificação de "Tendência Estacional", aplica-o, novamente, com os preços sem estarem deflacionados. Ao concluir, a partir da nova base de dados, que o método funciona em ambos os casos salienta:

Tende a eliminar parcialmente a influência da depreciação monetária. É interessante notar que este mesmo fato foi apontado por Henry Schultz $^{54}$ no apêndice B, pg. 709 do seu livro "The Theory and Measurement of Demand ${ }^{55}$, para o caso das curvas de demanda (DELFIM NETTO, 1952a, p. 32).

Conclui que não se pode afirmar que existe um "padrão de movimento estacional acentuado." Assim, até por esse motivo, o algodão poderia ser considerado uma cultura superior a outras (como ele mostra que é o café, questão discutida no capítulo terceiro dessa dissertação), pois seu preço não variava tanto assim.

Delfim comenta como o Brasil teria tido a produção algodoeira em três épocas distintas de seu desenvolvimento; "durante a revolução industrial”, "durante a guerra de Secessão nos EUA" e, “depois da crise do café, em 1930", contudo somente a última fora importante, tendo o Brasil se transformado no quarto maior produtor mundial (DELFIM NETTO, 1953d, p. 10), a qual permitiu um grande acréscimo da produção em São Paulo, tornando-se um produto relevante da pauta de exportação. Além disso, "internamente,

\footnotetext{
${ }^{53}$ Esse método nada mais é do que exprimir cada termo da série como porcentagem do termo anterior. Assim, se em junho tivemos o valor de 100, e em agosto de 200, a tabela das razões em cadeia irá dar como resultado o valor de $100 \%$ em agosto.

${ }^{54}$ Henry Schultz foi um dos fundadores da sociedade de econometria nos EUA.

${ }^{55}$ Interessante notar, que esse mesmo livro era parte da bibliografia da cadeira XX, com a matéria: "Valor e Formação dos Preços" lecionada no segundo ano do curso de economia pelo Professor Dorival Teixeira Vieira.
} 
não é menor o papel desempenhado pela cultura algodoeira. "De fato, ela fornece matéria prima para um dos mais importantes setores industriais, proporcionando emprego a uma grande soma de fatores de produção" (DELFIM NETTO, 1953d, p. 11). Aqui se vê o contraste entre uma cultura que "drena" os fatores de produção, com outra, que se apresenta quase como solução para se empregar os fatores de produção do país.

Delfim chama a atenção a todo momento que o aumento do desenvolvimento vem acompanhado de um aumento do consumo de algodão, pois assim o fora nos países do mundo, e o Brasil deveria estar preparado para tal.

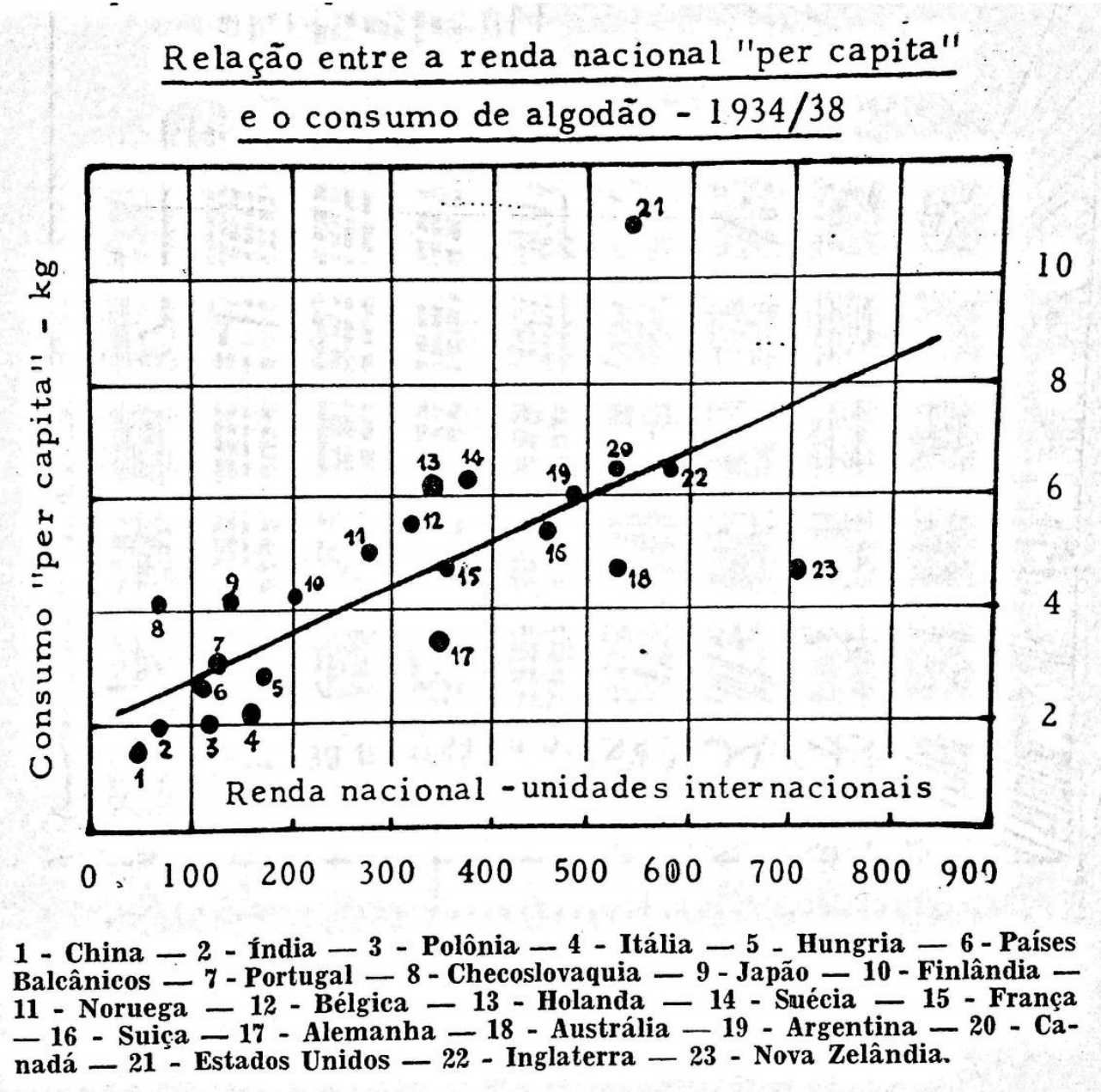

Fonte: (DELFIM NETTO; HAUSNER; STILMAN, 1954)

Delfim informa que o consumo Brasileiro haveria dobrado entre 1934-38 até 1954. Esse processo era "normal" para o desenvolvimento, pois, para o autor, quanto maior a renda "per capita", maior porcentagem dela seria gasta em bens não essenciais ${ }^{56}$, para utilizá-la

\footnotetext{
${ }^{56}$ Alimentos, e.g., são considerados bens mais essenciais do que vestuários.
} 
na compra de "tecidos para melhorar o seu vestuário, aquisição de geladeiras, rádios, etc" (DELFIM NETTO; HAUSNER; STILMAN, 1954, p. 10). As perspectivas de aumento do consumo de algodão no Brasil eram muito grandes naquele período, dado que o crescimento da renda "per capita" era estimada grande, assim como, o crescimento da população "aproximadamente 2 ou 3\% ao ano" (DELFIM NETTO; HAUSNER; STILMAN, 1954, p. 10). Além do algodão servir para vestuários, Delfim chama a atenção para a produção do óleo feito a partir do algodão, que poderia vir a servir para consumo da população ${ }^{57}$, e ainda, a fabricação de "tortas para a alimentação dos nossos crescentes rebanhos"58 (DELFIM NETTO; HAUSNER; STILMAN, 1954, p. 11). Portanto, o crescimento da produção de algodão seria "de suma importância para a manutenção, no futuro, da dieta do povo brasileiro" (DELFIM NETTO; HAUSNER; STILMAN, 1954, p. 10). Percebe-se como o algodão é visto para Delfim como um produto que entraria em diversas esferas do processo produtivo, e, também, como "bem-salário".

De outra maneira, além desta, o algodão ajudaria o desenvolvimento nacional com a expansão da indústria têxtil, porque teria sido nesse setor "que o algodão apresentou sua maior contribuição ao desenvolvimento da economia nacional" (DELFIM NETTO, 1953d, p. 11). Essas indústrias teriam passado a ter intenso desenvolvimento a partir da “guerra de 1914-1918" (DELFIM NETTO, 1953d, p. 12) contudo, faltaria infraestrutura e haveria um mercado diminuto, dada que não havia, ainda, uma alta concentração demográfica urbana no Brasil, para que esta indústria pudesse florir com vigor. Somente o "baixo preço da mão de obra e as dificuldades de importação" permitiram algum desenvolvimento da indústria durante o período de guerra, e após esta, a "adoção de uma política protecionista propiciaram novo impulso às atividades da indústria" (DELFIM NETTO, 1953d, p. 12). Pode-se observar como o as medidas protecionistas são importantes para Delfim, pois elas foram responsáveis, em parte, para o desenvolvimento industrial.

Por outro lado, "a inexistência de grandes unidades produtoras", não garantiriam uma atividade sempre rentável. O grande motivo para isso, seria que no Brasil "carecem

\footnotetext{
${ }^{57}$ Aparentemente, há uma correlação muito grande entre alguns óleos vegetais e o óleo de algodão. Em especial este com o óleo de soja, indicando uma alta substituição entre eles. C.f. Barbosa, Rocha, Freitas (1995).

58 Até hoje o subproduto do algodão é recomendado para a alimentação dos rebanhos. Para mais informações sobre esse assunto, c.f., por exemplo, Lima (2012) e Paim, Louvandini, Mcmanus, Abdalla (2010).
} 
capitais", que impediriam a instalação de grandes unidades produtoras, as quais diminuiriam o custo das empresas, tornando-as competitivas. O processo da "falta de capitais" seria quase como um círculo vicioso: "a baixa renda per capita dificulta a acumulação de capitais e a maioria das indústrias são firmas individuais que se expandem à custa do crédito bancário a prazo curto" (DELFIM NETTO, 1953d, p. 12), já se evidencia a dificuldade de obtenção de crédito a longo prazo. Apesar desse cenário pouco favorável, a partir da II Guerra Mundial, foi possível serem criadas condições que teriam permitido um “intenso surto industrial no Brasil” (DELFIM NETTO, 1953d, p. 12). Esse surto ocorreu pelas dificuldades de importação, e pelo maior aumento da procura interna resultado do aumento da população e das receitas provenientes das exportações.

A indústria têxtil teve um papel muito importante em todo esse processo, (contudo, ela não seria a única a empregar o algodão como matéria-prima). Haveria, também, "fabricação de óleo de caroço "e toda uma gama de subprodutos do caroço, linter etc" (DELFIM NETTO, 1953d, p. 12). Contando, em 1950, com 2.969 estabelecimentos, dos quais "mais de $50 \%$ se encontravam em São Paulo" e com um valor de produção que representava $17 \%$ do valor da produção industrial total, e, despendia em salários 6.158 milhões de cruzeiros, ou ainda, $22 \%$ de todo o pessoal empregado na indústria (DELFIM NETTO, 1953d, p. 12), tudo isso ressaltam a "importância da cultura algodoeira no Brasil (...) para a manutenção do ritmo do desenvolvimento econômico do país" (DELFIM NETTO, 1953d, p. 12).

Se por um lado as indústrias e o algodão eram tidas como parte fundamental para a continuidade do desenvolvimento brasileiro no Brasil naquele momento, por outro, a produtividade da indústria brasileira seria baixa, não só pelos problemas já apontados, como também pelos "problemas criados na indústria pelas leis trabalhistas", e ao "mau emprego do equipamento existente" o qual poderia ser melhorado "pela melhoria dos métodos de trabalho e pela correção de técnicas de fabricação" (DELFIM NETTO, 1953d, p. 12-13). Mesmo a produção do algodão seria muito custosa. Três seriam os maiores custos para Delfim (representando, aproximadamente, 60\% do custo total da cotonicultura): a colheita $(22,7 \%)$, o tratamento $(25 \%)$ e a adubação $(11,8 \%)$. A própria cultura agrícola (em especial as perecíveis) seria delicada frente a atividade industrial, pois aquela teria a sua oferta por "jactos", ou seja, como mostrado acima, não são oferecidos durante todo o ano, "ao contrário do que ocorre com os produzidos pela indústria” (DELFIM NETTO, 1953d, p. 13). Só esse fato serviria para deixar muito 
suscetíveis os produtores frente aos compradores, colocando, estes últimos, em uma posição de negociação muito mais vantajosa. Reduzindo, dessa forma, "a resistência econômica do agricultor" (DELFIM NETTO, 1953d, p. 13). Um outro problema da agricultura é que, na época da colheita, necessitaria o agricultor de um maior plantel de mão de obra do que no resto do ano, “já que as máquinas colhedoras ainda não encontraram entre nós condições para a generalização de seu uso" (DELFIM NETTO, 1953d, p. 14), transferindo, para Delfim, os ganhos dos agricultores para os trabalhadores (Delfim não se utiliza desse termo, apenas diz que se aumentam os custos consideravelmente). $\mathrm{O}$ tratamento do algodão se resumiria ao combate às pragas, feito ele pela importação de inseticidas e a adubação, a qual constitui em grande parte, por 'elementos importados". Todavia, naquele momento em 1953, Delfim vê o câmbio favorável à agricultura "É interessante notar que a manutenção da atual paridade cambial favorece o agricultor” (DELFIM NETTO, 1953d, p. 13) (mas com os problemas da balança de pagamentos piorando cada vez mais, essa visão irá mudar, transformando a falta de divisas estrangeiras no maior problema à produção). Se se considerar que haveria uma relação muito grande entre capacidade de importar e os salários dos trabalhadores, o câmbio faria um peso ainda maior nos custos de produção (sem contar os custos fixos, como máquinas e equipamentos, e.g., que dependeriam ainda mais da capacidade de importar). E é por isso, ainda mais, que o algodão seria tão importante; sua exportação aumentaria a capacidade de importar do Brasil, que representaria "fato vital para o seu desenvolvimento econômico" (DELFIM NETTO; HAUSNER; STILMAN, 1954, p. 13). Porque o Brasil só poderia "manter a atual taxa de desenvolvimento e acelerá-la se dispuser de poder de compra no exterior para importar o capital técnico de que necessita para o aumento da eficiência de sua produção" (DELFIM NETTO; HAUSNER; STILMAN, 1954, p. 13). Também deveria ser diminuída algumas das importações essenciais para a agricultura, ao se "intensificar a produção nacional de inseticidas e adubos" (DELFIM NETTO, 1953d, p. 19) liberando, assim, recursos para utilizar as divisas em outros lugares que garantissem o desenvolvimento. A mecanização agrícola era o fator decisivo para o aumento da produção e para "a liberação de boa parte da mão de obra", e, portanto, traria como consequência "o aumento da produção industrial". Então, para Delfim, aumentar a capacidade de importar era sinônimo de aumentar a industrialização, a qual, por sua vez, era sinônimo de um aumento do desenvolvimento. 


\subsection{Comércio internacional}

\subsubsection{O desequilíbrio nas transações comerciais internacionais}

Como foi exposto, o algodão era importante por proporcionar matéria prima às indústrias têxteis e, também, por ter um grande potencial em aumento de divisas. Este último ponto é fundamental para Delfim, porque seria o aumento da capacidade para importar que permitiria o aumento do desenvolvimento ${ }^{59}$. Contudo, o Brasil, por não ser um país industrializado, sofria de condições especiais no comércio exterior, tendo dificuldades em manter a sua balança de pagamentos superavitária. Mesmo que tenha havido industrialização no Brasil (de forma robusta) após a segunda guerra mundial, o Brasil não chegou a ter um "desenvolvimento orgânico" (DELFIM NETTO, 1953d, p. 10). Em contraste com os "países industrializados", "com alta renda nacional per capita, nos quais a maior parte da população se dedica a atividade industriais" seriam "os próprios investimentos interno que impulsionam o crescimento do nível de renda nacional" (DELFIM NETTO, 1953d, p. 09), o Brasil seria "subdesenvolvido", com uma renda nacional "per capita" diminuta, e "onde a maioria da população se dedica a atividades agrícolas", tendo, ao contrário dos países industrializados, as "exportações" como principal papel ativo dos investimentos. Em outras palavras, o desenvolvimento orgânico somente ocorreria quando os maiores determinantes do crescimento seriam determinados pelos investimentos internos, e, não, nos setores de exportação. Indicação de um país voltado para fora, e com uma industrialização não suficiente para ser um país desenvolvido.

Essa tese é - com ressalvas - comum a alguns autores da época de notadamente diferente cunho político. O problema de ser um país voltado para fora, cujo emprego (e o investimento) dependia da demanda forânea fora abordado por outros autores. Mesmo Caio Prado Júnior (1954), e.g., no livro "Diretrizes para um Política Econômica Brasileira", traz à baila argumentos similares. A linha mestra condutora desta tese de Caio Prado Júnior é o sentido para fora no qual a economia brasileira se encontraria, e na qual sempre se encontrara, desde a sua criação como colônia exportadora, até o momento em que escrevia. Essa escassez de mercado interno teria na raiz o desenvolvimento histórico

\footnotetext{
59 “O desenvolvimento da produção de algodão no Brasil é fundamental, não apenas para atendimento do aumento do consumo interno, seja sob a forma de vestuário, tecidos, lonas, óleos ou torta, mas também para o incremento das nossas exportações desse produto, uma vez que as cambiais delas resultantes contribuirão para manter a continuidade do nosso desenvolvimento" (DELFIM NETTO; HAUSNER; STILMAN, 1954, p. 11, grifos meus).
} 
do país como fornecedor de produtos para o exterior, não tornando orgânico a integração das diferentes áreas de produção e consumo internas, sendo elas cindidas. Teriam então no externo o estímulo econômico, e por isso, cindindo - alienando - as diferentes regiões internas. Ao invés de ter interno este estímulo, e com ele integrando o Brasil ${ }^{60}$. O desenvolvimento econômico, então, para Prado Junior (1954) não dependeria de uma simples "substituição de importações" ou mesmo, de uma "simples difusão da técnica moderna" ${ }^{61}$. Claro que, se o diagnóstico é parecido, a solução proposta pelos autores é bem diferente. Caio Prado Junior anseia por uma revolução aos moldes soviéticos, enquanto, para Delfim (como ficará mais claro com o decorrer dessa dissertação) a solução seria um governo capaz de coadunar as vontades dos trabalhadores e dos empresários.

Não pretendo com isso dizer que devemos aspirar a uma autosuficiência econômica e isolamento comercial, o que em qualquer circunstância do mundo moderno constitui uma utopia; e que no caso em particular não é nem imaginável". (...) "Em outras palavras e mais precisamente, trata-se de cuidar com a maior atenção do movimento de nossas transações externas, tirando delas o máximo e necessário proveito para que elas representem cada vez com menor destaque o papel de fulcro da economia brasileira que atualmente constituem (PRADO JÚNIOR, 1954, p. 223-224).

A maior parte das indústrias brasileiras viverá prioritariamente da contínua depreciação cambial e das pesadas tarifas alfandegárias que graças a esta desvalorização se faziam cada vez maiores. Não haverá para elas, ou haverá em grau insuficiente, a luta pela conquista e alargamento dos mercados que constitui o grande estímulo progressista das empresas capitalistas e o responsável principal do vertiginoso desenvolvimento da indústria moderna (PRADO JÚNIOR, 1954, p. 129).

Continuando com a exposição do argumento de Delfim, o fato de este ser um país subdesenvolvido, ou seja, de ter grande parte da produção voltada para a exportação de produtos agrícolas agrava ainda mais a situação do país já mais pobre. Pois, países “subdesenvolvidos, produzindo notadamente matérias primas de baixo valor específico, nunca poderão tornar ativa sua balança de pagamentos e, para eles, o padrão ouro representa perda continua de substância” (DELFIM NETTO, 1953a, p. 21). Isso aconteceria devido a alguns fatores: i) as matérias primas possuírem, em geral, elasticidades acentuadas com

\footnotetext{
${ }^{60}$ Mesmo antes, em seu livro "Formação do Brasil Contemporâneo", publicado em 1942, o problema do Brasil seria seu sentido voltado para fora.

${ }^{61}$ Em concordância com essa interpretação sobre esta obra de Caio Prado Jr. encontra-se Paula (2006).
} 
relação a renda, "de maneira que, uma redução desta tende a retrair a procura desses bens mais do que proporcionalmente à queda da renda" (DELFIM NETTO, 1953d, p. 09); ii) pequena elasticidade (ou quase inelasticidade de curto prazo) da oferta dos produtos agrícolas (perenidade de algumas culturas, "relativa inércia dos agricultores" em relação à área plantada e a falta de informações adequadas sobre a situação dos países consumidores); iii) redução violenta dos preços não é acompanhada por um aumento da quantidade exportada; iv) importação dos países subdesenvolvidos inelástica (se constituem principalmente de bens de capital e bens de consumo essenciais); v) "relações comerciais impõem aos países sub-desenvolvidos, de estrutura agrícola, uma situação de inferioridade com relação aos países industrializados” (DELFIM NETTO, 1953d, p. 10); vi) Esse fato é evidenciado "pela grande dependência dos países agrícolas com relação às suas exportações” (DELFIM NETTO, 1953d, p. 10); vii) exportação concentrada em poucos produtos. Todos esses fatores "de extrema dependência do comércio exterior" levariam aos países de economia agrícola a estar sujeito “aos reflexos” dos países industrializados, "criando-lhes, não raras vezes, situações mais críticas do que as enfrentadas pelos países condutores” (DELFIM NETTO, 1953d, p. 10).

Se se buscar no Formação Econômica de Furtado, lançado em 1959, pode ser encontrado argumento muito semelhante a esse de Delfim. Diz aquele que havia realmente que as economias: i) "dependentes (...) estiveram sempre condenadas a desequilíbrios de balança de pagamentos e à inflação monetária" (FURTADO, [1959] 2007, p. 227). Esse fato ocorreria, pois, "no momento em que deflagrava uma crise nos centros industriais, os preços dos produtos primários caíram bruscamente, reduzindo-se de imediato a entrada de divisas no país de economia dependente" (FURTADO, [1959] 2007, p. 226); em outras palavras, haveria uma elasticidade-renda muito alta em relação ao consumo dos produtos produzidos nos países dependentes pelos países desenvolvidos. Mesmo assim, após a crise, haveria ainda, ii) "uma etapa intermédia em que a procura de importações crescendo, se bem que a oferta de divisas já se houvesse reduzido drasticamente" (FURTADO, [1959] 2007, p. 226); em outras palavras, importação de bens desses países poderia ser considerada inelástica (ou quase); iii) o desemprego viria de fora para dentro “A crise penetrava neste de fora para dentro e seu impacto alcançava necessariamente grandes proporções" (FURTADO, [1959] 2007, p. 235); Assim, era a crise no setor exportador que determinava o nível de investimento do país e, quando entrava em crise esse setor, levava junto, todos os outros setores da economia; iv) “durante a depressão, as 
importações que se contraíam menos - dada a baixa elasticidade-renda de sua procura eram aquelas de produtos essenciais utilizados pela grande massa consumidora" (FURTADO, [1959] 2007, p. 238); v) baixa elasticidade da oferta agrícola:

A plantação de café significa uma inversão a longo prazo com grandes imobilizações de capital. A terra ocupada pelo café não pode ser utilizada senão de outra forma subsidiária para outras culturas. Não existe, como no caso dos cereais, a possibilidade de reduzir, no período produtivo seguinte, a área semeada (FURTADO, [1959] 2007, p. 240).

Nos parece, aqui, que a percepção do mecanismo de constante perda da balança de pagamentos para os dois autores (Delfim e Furtado) é muito semelhante (para não dizer igual). A grande diferença é que, para Delfim, toda a industrialização que o Brasil havia passado no pós-guerra, até então, seu momento coetâneo não havia sido suficiente para a possibilidade de um “desenvolvimento orgânico" (em suas próprias palavras). Já, para Furtado, tudo indica que esse mecanismo funcionara até a década de 1930, quando a partir daí passa a ser o mercado interno o principal motor da economia. "Contudo, o fator dinâmico principal, nos anos que se seguem à crise, passa a ser, sem nenhuma dúvida, o mercado interno" (FURTADO, [1959] 2007, p. 278). Estando o Brasil livre do setor externo, e tendo como fator mais dinâmico o setor interno, a saída para a crise - para Furtado - seria aumentar o mercado interno. Caso não fosse assim, e o sistema econômico ainda estivesse subsidiado ao setor exportador, o aumento da demanda interna não serviria como solução para o problema do desenvolvimento.

Essa interpretação de Furtado remete a uma outra, seminal, apresentada por Prebisch em 1949, e desenvolvida por ele, ainda, em 1950 e em 1951. Mais do que propriamente questionar "o raciocínio concernente aos benefícios econômicos da divisão internacional do trabalho" pois elas teriam uma "incontestável validade teórica" (PREBISCH, 1949; p. 71), Prebisch questiona que essa teoria "se baseia numa premissa que é terminantemente desmentida pelos fatos" (PREBISCH, 1949, p. 47). Em concordância com Soares (2004), a premissa que Prebisch estaria questionando seria que a hipótese da livre concorrência já não mais valeria no comércio internacional, tornando, portanto, a teoria das vantagens comparativas ricardianas (a qual seria de "validade teórica inobjetável”), sem utilidade prática para o entendimento do mundo naquele momento. Vejamos, então, o que diz Prebisch:

Como explicar que, no correr do tempo e através dos séculos, a renda do centro tenha crescido mais do que na periferia? Não há contradição alguma entre esses dois fenômenos. Os preços 
primários sobem com mais rapidez do que os finais na fase ascendente, mas também descem mais do que estes na fase descendente, de tal forma que os preços finais vão-se distanciando progressivamente dos primários através dos ciclos (PREBISCH, 1949, p. 86).

Ou seja, isso é o mesmo que dizer que existe uma elasticidade renda dos produtos primárias "acentuada" (como diz Delfim). Continua Prebisch, esse fenômeno se daria porque o lucro dos empresários não se contrairiam "da mesma forma que se dilatou [na fase ascendente]", se isso ocorresse, não "haveria razão alguma para que ocorresse esse movimento desigual. Ele ocorre, precisamente, porque a contração não se dá dessa maneira" (PREBISCH, 1949, p. 86-87). Para Prebisch, e a forma como ele é mais comumente lido, o lucro nos grandes centros não consegue, na fase descendente (crise), contrair os salários ("em virtude da conhecida resistência à queda dos salários" (PREBISCH, 1949, p. 87) por razões de uma organização trabalhadoras. Por outro lado, “a desorganização característica das massas trabalhadoras na produção primária, especialmente na agricultura dos países da periferia" (PREBISCH, 1949, p. 87) as impediria de conseguirem os aumentos salariais, pesando, sobre eles, então, o ajuste das crises no centro do capitalismo.

Por outro lado, as coisas não acabariam por aí. Pois, "mesmo que se conceba na periferia uma rigidez parecida com a do centro" (PREBISCH, 1949, p. 87), i.e., mesmo que os trabalhadores na periferia conseguissem se organizar e fazer reajustes salariais (aos moldes dos trabalhadores do centro do capitalismo), "isso teria como efeito aumentar a intensidade da pressão deste sobre aquela" (PREBISCH, 1949, p. 87). Ou seja, o argumento de que a deterioração se dá por causa última como rigidez (e/falta dela) dos salários é falso. Porque, como Prebisch explicita, mesmo em uma situação na qual a rigidez aconteça, a deterioração continuaria acontecendo. Haveria uma contração da produção industrial nos centros, e, "por conseguinte, da demanda de produtos primários. E essa diminuição da demanda acaba sendo tão acentuada quanto for preciso para obter a contração necessária da renda no setor primário" e isso só seria possível pois os centros cíclicos teriam a capacidade "de deslocar a pressão cíclica para a periferia, obrigando-a a contrair sua renda mais acentuadamente do que nos centros" (PREBISCH, 1949, p. 87). A questão para ser respondida é, porque os centros teriam essa capacidade de obrigar a periferia a contrair a renda mais acentuadamente? Isso apenas se daria ou por uma coerção a força (algo que não parece o caso) ou porque os produtos do centro são mais fundamentais para a periferia, do que os produtos destes, para o centro. Isso só seria 
possível se a oferta dos produtos para o centro fosse mais inelástica e, se, a demanda do centro para a periferia fosse mais elástica, possibilitando que o centro impusesse uma maior contração da renda para a periferia. Para explicar essas diferenças nas elasticidades - sempre favoráveis aos países centrais - Soares (2004) interpreta esse texto de Prebisch dizendo que, na verdade, a assimetria fundamental entre o centro e a periferia seria que naquele haveria monopólios (tanto na oferta quanto na demanda) e os países periféricos teriam um mercado "atomizado" (concorrencial), assim, o ganho de produtividade ficaria para os países centrais, e, as crises, "apertariam" seriam repassados aos países periféricos ${ }^{62}$.

Dessa forma, tanto Delfim quanto Prebisch perceberiam uma assimetria no comércio internacional, dada pela capacidade que os países industrializados/desenvolvidos/centrais conseguiriam um maior poder de barganha em relação aos países não industrializados/subdesenvolvidos/periféricos. As elasticidades seriam tais, portanto, que beneficiariam sempre aqueles países no comércio internacional em detrimento dos países periféricos ${ }^{63}$. Contudo, para Prebisch, essa assimetria era dada pela diferença da estrutura

\footnotetext{
${ }^{62}$ Diz Soares (2004, p. 11-12) "Existe algo de contestatório em se reconhecer que a hipótese de livreconcorrência não é útil para explicar o que estava acontecendo no mercado internacional? A resposta a essa questão pode ser fornecida com o recurso a um famoso texto sobre metodologia científica escrito por Milton Friedman. Friedman (1974; p. 35) começa por lembrar que Alfred Marshall "levou em consideração o mundo como ele é; ele tentou construir um mecanismo para analisá-lo e não uma reprodução fotográfica dele". Assim, "construiu a hipótese de que, para muitos problemas, as firmas podem ser agrupadas em indústrias, se as similaridades entre elas eram mais importantes do que as diferenças". O modelo abstrato correspondente a essa hipótese contém dois tipos ideais de firmas: "firmas atomisticamente competitivas, agrupadas em indústrias" e "firmas monopolistas". A indústria é constituída por um grupo de firmas produzindo um único produto, definido como uma coleção de unidades com perfeita substituição entre elas. Diferentes unidades constituem um mesmo produto quando a elasticidade de substituição entre elas é infinita. Uma firma é competitiva quando a elasticidade de demanda pelo seu produto é infinita. Se a curva de demanda não for perfeitamente elástica a firma é monopolista e é a própria indústria. O que caracteriza a concorrência perfeita e o monopólio é a elasticidade da curva de demanda. Na concorrência perfeita a curva de demanda é perfeitamente elástica. Como nenhuma curva de demanda é perfeitamente elástica, a questão relevante é se uma dada elasticidade é grande o suficiente para ser dita perfeitamente elástica. Concorrência perfeita e monopólio são tipos ideais e, como tal, não foram construídos para descrever situações mas, para isolar as características cruciais do problema. O critério para se definir se num particular mercado vigora a concorrência perfeita ou o monopólio é empírico, é de ordem prática."

${ }^{63}$ Guimarães (2005, p. 110) diz o seguinte sobre o assunto: "Outra variável explicativa da deterioração dos termos de troca é o facto de os produtos primários terem uma elasticidade rendimento da procura menor que os produtos industriais. Este facto faz com que diminua a procura e os preços dos bens primários relativamente aos bens industriais, os quais tem uma maior elasticidade de rendimento. De facto, Raúl Prebisch e Hans Singer, baseando-se na Lei de Engels, que afirma que a percentagem de rendimento dispendida em bens alimentares se torna menor à medida que o rendimento aumenta, argumentaram que os termos de troca entre países em desenvolvimento e países industrializados se deterioraram ao longo do tempo. Uma vez que a maioria dos bens exportados pelos países em desenvolvimento são bens agrícolas, Prebisch e Singer concluem que a procura destes bens não aumenta proporcionalmente ao aumento do rendimento nos países industrializados, diminuindo os preços das exportações dos países em desenvolvimento relativamente aos preços dos bens manufacturados nos países em desenvolvimento relativamente aos preços dos bens manufaturados nos países industrializados.”
} 
dos mercados, lá um monopólio, cá, atomizado. A solução, seria - ainda concordando com Soares (2004) - para Prebisch, o restabelecimento da concorrência, que só poderia ser obtido pela industrialização da periferia. Já, para Delfim, essas mesmas diferenças aparentes nas elasticidades seriam dadas pelos diferentes tipos de produtos oferecidos, aqueles que ofereciam produtos agrícolas/primários teriam menores elasticidades na oferta (pois é muito mais difícil ajustar a produção de algum produto natural, do que a produção de um produto industrial), e menores elasticidades na demanda (os bens dos países centrais seriam mais essenciais para os países periféricos do que os dos países periféricos para os países centrais). A solução, seria, então, a produção de bens industriais (o que é o mesmo que a industrialização), para retomar o poder de barganha dentro do mercado com produtos que permitiriam uma elasticidade vantajosa ao produtor no comércio. Seu ponto principal é que os países quando não industrializados e dependentes de exportação de produtos primários, sofrem mais em tempos de crise com o livrecambismo:

Essa dependência das exportações, aliada à que elas constituem, principalmente, de matérias primas para a indústria e de artigos de alimentação, fazem com que, quando existem uma retração da atividade econômica dos países industrializados, caiam não só os preços como o volume de suas exportações (...) a única forma eficaz de reduzir nosso montante de importações é passarmos a produzir os produtos importados, através de uma industrialização mais rápida (DELFIM NETTO, 1953a, p. 22, grifos meus).

Delfim constrói uma narrativa para explicar sua visão quanto ao comércio internacional.

Cita Ricardo, para introduzir o argumento livre-cambista:

De fato, Ricardo mostrou que, desde que o regime funcionasse, todos os países tenderiam a adquirir e pemanecer com um estoque de ouro de acordo com a sua estrutura e tal que produzisse o nivelamento internacional de preços (DELFIM NETTO, 1953a, p. 21).

Mas ele questiona essa visão, exemplificando este último ponto, cita Samuelson (1938) no artigo "Welfare economics and international trade", no qual em uma situação de monopólio bilateral a lei das vantagens comparativas não é válida; "uma simples exceção destrói completamente a universalidade da proposição" (DELFIM NETTO, 1957b, p. 24). Dessa forma, as leis "universais" de vantagens comparativas de Ricardo para o comércio exterior não seriam sempre válidas, e, portanto, não seriam universais. Ainda mais, ao questionar a visão clássica de Ricardo sobre o comércio internacional: 
$\mathrm{O}$ argumento clássico supunha, essencialmente, movimentos de preços de pequena amplitude e, por isso, exigia uma alta elasticidade das procuras. Se os movimentos fossem mais acentuados, as alterações de preços seriam violentas e causariam sérias perturbações na economia dos países envolvidos. (...)os países de estrutura e sub-desenvolvidos, produzindo notadamente matérias primas de baixo valor específico, nunca poderão tornar ativa sua balança de pagamentos e, para eles, o padrão ouro representa perda continua de substância. List mostrou que as diferenças de estruturas econômicas não permitem a aceitação do liberalismo, necessário ao próprio funcionamento do padrão ouro (DELFIM NETTO, 1953a, p. 21)

O estudo das teorias de Ricardo e List eram tópicos obrigatórios da matéria na faculdade "História das doutrinas econômicas". Ainda, ao se referir a forma moderna de câmbio com a moeda sem ser lastreada em ouro - é contra o argumento livre-cambista, referindose a Taussig ${ }^{64}$ e suas análises empíricas que teria observado que a "rapidez com que a balança de pagamentos parecia adaptar-se ao esquema clássico, sugeria que aquelas explicação era incompleta, devendo o mecanismo de ajuste ser influído por outros fatores.” (DELFIM NETTO, 1953a, p. 21)

Para discutir a desvalorização cambial, utiliza-se de três autores para dialogarem entre si: Marshall, que mostrou que se "a soma das elasticidades das procuras nos dois países em comércio fosse inferior à unidade, a desvalorização teria um efeito desfavorável sobre a balança comercial” (DELFIM NETTO, 1953b, p. 15). Joan Robinson, que na mesma linha de Marshall, afirma que quanto mais inelástica a procura internacional por bens doméstico, menor será o efeito na balança de pagamentos de uma desvalorização ${ }^{65}$. Por

\footnotetext{
${ }^{64}$ Esse argumento de Taussig Delfim nos informa que se encontra em "Metzler, Lloyd A. - The theory of international trade, in "A survey of contemporary economics" - Editado por Howard S. Ellis - The Blakiston Company - The Blakiston Company - Filadelfia, 1948 -p. 210.

No livro, Tariff History of United States, Taussig é da posição que as tarifas protetoras da indústria, no período antes de 1860, estadunidense foram de pouca importância para estímulo industrial. Já no livro, Some Aspects of the Tariff Question, ele muda de opinião afirmando que as tarifas foram importantes para o desenvolvimento das manufaturas nos EUA.

${ }^{65}$ “O menor efeito da desvalorização corresponderá a uma procura estrangeira absolutamente inelástica, porque, neste caso, não haverá qualquer aumento das exportações. $O$ efeito máximo consiste na combinação de uma procura estrangeira e uma oferta nacional perfeitamente elásticas." (DELFIM NETTO, 1953b, p. 16) continua na página seguinte: "A análise dessas fórmulas [Desenvolvidas por Joan Robinson] mostra que: a) se a procura nacional for extra-elástca, uma desvalorização deve aumentar a balança de comércio, porque o valor das importações(...) b)se a procura nacional de importação for inelástica, a balança de comércio sòmente aumentará se houver um incremento suficiente das exportações (...) c)quando a balança comercial estiver em equilíbrio no primeiro momento, se a elasticidade da procura estrangeira for maior que 1, a desvalorização melhorará a balança comercial(...) d)se a elasticidade da procura estrangeira for menor do que 1, a balança comercial melhorará, se a elasticidade da procura interna for suficiente para compensar a baixa elasticidade da procura estrangeira." (DELFIM NETTO, 1953b, p. 17) e, "A pequena elasticidade que foi observada em muitos estudos empíricos sôbre as curvas de procura, parece mostrar que, a curto prazo, a depreciação não pode melhorar sensivelmente a balança de pagamentos de um país, a menos que a procura inelástica de importação seja contrastada por uma correspondente oferta inelástica de exportação.” (DELFIM NETTO, 1953a, p. 17)
} 
último, com Hirschmann, o qual afirma que desvalorizar a moeda não necessariamente aumenta as divisas de um país. E adverte que a análise desse autor é de caráter menos geral do que a do Robinson ${ }^{66}$. Todos esses autores, com exceção de Hirschman, eram parte da bibliografia fundamental dos cursos "Valor e Formação de Preços" e "Moeda e Crédito". Delfim, por outro lado, também introduz um modelo matemático para explicar as "condições de estabilidade do equilíbrio" no comércio exterior, o qual "nos cursos comuns, não pode ser desenvolvida adequadamente, pelo complicado instrumental que exige" (DELFIM NETTO, 1955-1956, p. 55).

As hipóteses do modelo são que só há dois países, somente um produto de exportação e um de importação para cada país, e a existência de liberdade total de comércio entre os países. No último tópico do artigo, introduzirá uma hipótese adicional, a saber, de elasticidades constantes da oferta e da procura as quais permitirão "deduzir algumas fórmulas clássicas da estabilidade da taxa de câmbio de equilíbrio". Entretanto, Delfim não pretende ter originalidade - total - no artigo. Informa ao leitor que o modelo será um caso particular simples do "magnífico livro de Bresciani-Turroni" (DELFIM NETTO, 1955-1956, p. 56) ${ }^{67}$. O livro ao qual se refere, é Corso di Economia Política, de 1951. A referência a Turroni aparecerá novamente, mas, pela única vez nos escritos aqui analisados, será dita que a referência é a esse livro. Do livro "conversas com economistas" ${ }^{\$ 68}$ sabemos que esse livro foi muito importante para a formação de Delfim como economistas, em suas palavras:

O livro que mais me influenciou nessa época foi o de Bresciani Turroni, Curso de Economia Política $[1960]^{69}$. O primeiro volume cuidava de formação de preço, teoria do valor, e o segundo, da parte da moeda, de comércio internacional. Claro que tudo isso desapareceu depois que apareceu Samuelson. Ele produziu um estrago de tal natureza que as pessoas acreditaram que toda a Economia vinha de Cambridge, Estados Unidos. No tempo que eu estudava seguia-se a

\footnotetext{
66 "Joan Robinson mostrou que, para os países que possuem sua exportação rigorosamente concentrada em poucos produtos e a importação altamente diversificada (que é o caso típico do Brasil), as relações de troca, provàvelmente, se deteriorizarão para o país que desvaloriza, mesmo nos casos em que a balança de pagamento melhora." (DELFIM NETTO, 1953a, p. 21)

${ }^{67}$ Cita, ainda, o livro de J. B. Willians, International trade under flxible Exchange rates, 1954. Diz-nos que esse livro "torna mais rigorosa, do ponto de vista lógico, certas demonstrações encontradas comumente nos livros que tratam da teoria do comércio internacional" (DELFIM NETTO, 1955-1956, p. 56)

${ }^{68}$ CIRO, B.; COZAC, L. F. L.; REGO, J. M. Conversas com Economistas Brasileiros São Paulo: Editora 34,1996.(pp. 89-125)

${ }^{69}$ A data de publicação que Ciro et al dão para a publicação do livro do Turroni, Curso de Economia política é de 1960. Essa data na refere-se a data a qual Delfim obteve conhecimento deste livro. Sabemos que o livro fora editado em 1951.
} 
linha de Cambridge, Inglaterra (DELFIM NETTO, 1955-1956, p. 91, grifos meus)

Mesmo não querendo propor um modelo "original”, entretanto, quer-se almejar outro objetivo com o artigo. Para Delfim, Turroni havia mostrado como se forma a taxa de câmbio; ele, por sua vez queria determinar “(...) que relação existe entre as curvas de oferta e de procura de mercadorias ou de serviços e as curvas de oferta e de procura de divisas" (DELFIM NETTO, 1955-1956, p. 56). Para tanto, exemplifica valores para oferta e procura de dois bens 'M1' e 'M2', para os dois países, supondo - como dito - que cada país exporta um bem que o outro importa.

Feito isso, passa ao ponto de entender como seria esse mesmo modelo caso as elasticidades fossem constantes. Conclui que a importação de divisas depende da elasticidade da curva de procura nacional por bens estrangeiros e a exportação estrangeira de divisas, depende da elasticidade da curva de oferta estrangeira. Para encontrar o equilíbrio da balança de pagamentos, a partir das curvas ilustradas, chega à fórmula de Joan Robinson (a mesma citada no trabalho da Revista dos Mercados (DELFIM NETTO, 1953a e DELFIM NETTO, 1953b)). Naquele trabalho concluíra que se "a soma das elasticidades das procuras nos dois países em comércio fosse inferior à unidade, a desvalorização teria um efeito desfavorável sobre a balança comercial" (DELFIM NETTO, 1953b, p. 15). Dito isso, parte para saber qual deva ser a desvalorização necessária para se corrigir o desequilíbrio na balança, caso esse exista, e caso seja possível corrigi-lo com uma desvalorização. Só será possível melhorar o balanço de pagamento, caso tenhamos uma combinação dos seguintes fatores: i) a elasticidade da curva de oferta nacional deve ser igual a zero; ii) a elasticidade da curva de oferta estrangeira deve tender para a elasticidade da curva de procura nacional; iii) a elasticidade da curva de procura nacional deve ser maior que zero. Desses três fatores combinados se teria a condição de Marshall-Lerner respeitada e sim, uma desvalorização no câmbio melhoraria a situação do balanço de pagamentos. Como vimos, essa é, simplesmente, um formato matematizado para Delfim dizer que não adiantaria simplesmente desvalorizar o câmbio para este entrar em equilíbrio.

Para discutir como se forma a taxa de câmbio, introduz curvas de ofertas e procuras da moeda nacional em termos da estrangeira, e aprofunda-se, ao analisar a balança de pagamentos, em duas teorias: "A Teoria da Paridade do Poder de Compra”, e o conceito de "Taxa de Equilíbrio". Esta última definida como aquela capaz de manter, em um 
período de tempo, a balança de pagamentos em equilíbrio. Introduzido os conceitos, parte-se para a análise de como reestabelecer o equilíbrio na balança de pagamentos, assim que ele se rompe. Como possibilidade, apresenta o "O Sistema de Taxas Múltiplas”, e utilizando-se de Gudin, afirma:

O prof. Eugênio Gudin e Jorge Kingston fizeram uma análise da taxa de equilíbrio de cruzeiro utilizando um método idealizado por Colin Clark e mostraram que, naquela ocasião, o sistema de taxas múltiplas poderia ser utilizado no Brasil, chegando mesmo a estabelecer, tentativamente, duas taxas com relação ao dólar: uma que seria a própria taxa em vigência e que vigoraria para as exportações do café (com uma redução de $\mathbf{1 0 \%}$ ) e para as importações de mercadorias de primeiras necessidade (excluindo a gasolina) e outra de $\mathrm{Cr} \$ 26,00$ por dólar para as demais operações (DELFIM NETTO, 1953a, p. 22).

É interessante observar como Delfim se aproxima de Gudin e Samuelson, dois nomes "respeitados" dentro da ortodoxia, que não poderiam apresentar "riscos" a interpretação de Delfim, imaculando-a, contudo, são dois autores muito defensores do argumento clássico do comércio internacional. Gudin, e.g., chega a dizer:

As 'teorias' do desenvolvimento econômico são, como sabemos, múltiplas e variadas. É o 'desenvolvimento balanceado' de RosensteinRodan e Nurkse, é o 'imbalanceado' de Hirschman; é o 'take-off' de Rostow; são as fórmulas de Harrod-Domar; é o critério da produtividade marginal social (SPM) de Khan; é o de Galenson \& Leibenstein de maximização, não da renda nacional, mas da poupança, através da taxa de lucros etc. O que se pode dizer da maioria dessas teorias é que há nelas muita imaginação, mas pouca teoria. Ao passo que a teoria do Comércio Internacional aí está há século e meio com seus postulados fundamentais de pé (GUDIN, 1962, p. 23, grifos meus).

Samuelson, por outro lado entrou para a história como "a visão ortodoxa predominante sobre o comércio internacional no pós-guerra". Em artigo de 1948 e depois em 1949 sendo atendidas algumas premissas -, o livre comércio levaria à equalização da remuneração dos fatores de produção, ou seja, não haveria desequilíbrio no comércio internacional, e, portanto, nenhuma necessidade em industrializar um país para reverter alguma deficiência no comércio internacional.

Dessa forma, mesmo que a interpretação do comércio internacional de Delfim não seja exatamente a mesma da de Furtado, ou, ainda, da de Prebisch, as políticas recomendadas a partir deles (industrialização) teriam muito mais em comum do que um diagnóstico a 
partir de Gudin, ou Samuelson. Mas, Delfim enquanto não cita em nenhum momento aqueles, sempre que pode, cita estes.

Quando Delfim está defendendo qual tipo de câmbio deveria ser adotado no Brasil, ele quer propor uma terceira via:

De um lado [das discussões a respeito do câmbio no Brasil], partidários irrestritos do "laissez-faire", criticam-no [o controle cambial] sob todos os seus ângulos, sem conceder grande atenção à realidade a êle subjacente; de outro, planificadores diretos cumulam-no de louvores, procurando negar todos os seus defeitos. Se, do ponto de vista doutrinário essas posições se defendem, do ponto de vista prático é preciso reconhecer que, num sistema capitalista liberal como o nosso, onde se pretende manter a existência de um mercado de trabalho, a propriedade privada e, principalmente, a autonomia da procura, os controles foram introduzidos por necessidade e não por prazer. Depois da grande depressão e da desconfiança que se instaurou no mundo, pràticamente nenhum país pôde manter-se fora de uma ou de outra forma de controle (DELFIM NETTO, 1955a, p. 10).

Nesse trecho, podemos perceber que a posição de Delfim é colocada não como "um ponto de vista doutrinário"; pelo ao contrário, ele seria daqueles que estaria tentando entender quais seriam os "mínimos controles" que se deveriam se ter para poder-se manter o funcionamento de um "capitalismo liberal" em:

Países como o nosso, onde os poderes políticos não se respeitam e onde normalmente o legislativo com raríssimas exceções, é constituído pela mais fina nata dos "efeitos na inflação" e o executivo prefere resolver tudo sòzinho, a tentativa de perpetuação do regime de contrôle, em função do poder que concentra nas mãos dos dirigentes do país, é um fato que deve ser levado em consideração. Entretanto, é preciso que se reconheça que o sistema de contrôle não é errado em si e pode e deve ser utilizado quando a situação exigir. (DELFIM NETTO, 1955a, p. 11)

Ele não é contra os controles cambiais, mas sim, a forma pela qual esses controles estão sendo "perpetuados" pelo "legislativo" e "executivo". Frisa-se, aqui, que um dos pontos salientados é o poder que se concentra nas mãos dos dirigentes do país, que são a "mais fina nata dos efeitos na inflação" e onde "os poderes políticos não se respeitam". Em suma, o sistema político daquele período era - no mínimo para Delfim - ineficaz para o correto desenvolvimento. Delfim expõe o que consideraria os dois casos de desequilíbrio cambial. O primeiro seria devido a uma mudança entre os níveis de preços interno e externo; o segundo, a uma mudança nas condições da oferta estrangeira de bens ou da procura nacional. Ambos, contudo, estariam ligados (direta ou indiretamente) com a inflação, que iremos tratar a seguir. 


\subsubsection{Nota sobre a Proteção à Indústria}

Em 1957, estava-se discutindo uma reforma tarifária com a chamada "Lei da Reforma das Tarifas das Alfândegas" (Lei n 3.244, de 14.08.1957), que - quando aprovada reintroduziu o regime de tarifas alfandegárias "ad-valorem", com dois diferentes grupos tarifários. O primeiro, geral, para bens "cuja oferta interna era insatisfatória”; o segundo, especial, para a maioria dos produtos acabados e bens de produção disponíveis no mercado interno" (SUPLICY, 1974). Essa lei veio a reforçar a proteção industrial nacional, dado que as antigas taxas ("regime de tarifas alfandegárias específicas") tinham valores fixos, e não se atualizaram com o aumento de preços registrado no pós-guerra (MUNHOZ, 2012, p. 31 et seq.).

Contudo, esse debate da reforma tarifária não é central para Delfim, mas sim a reforma cambial que estaria sendo proposta (e não foi implementada) - em subjacência àquela tarifária - de unificação das quatro primeiras categorias, a qual provavelmente levaria a "uma elevação geral dos preços dos produtos importados" (DELFIM NETTO, 1957b, p. 43). Havia, desde a implementação da Sumoc 70 em 1953 (ainda no governo Vargas), cinco categorias cambiais diferentes para importação reguladas por leilão público, e por isso “(...) o mercado cambial está em equilíbrio, pois o preço das divisas (dólar oficial mais ágio) é tal que equilibra, automaticamente, oferta e procura" (DELFIM NETTO, 1957b, p. 27$)^{70}$.

Com a Sumoc 70, as categorias de bens essenciais (fertilizantes, papel para imprensa, trigo, petróleo, derivados do petróleo, amortizações e pagamento de juros) eram sujeitas a uma taxa cambial bastante valorizada, "igual, em geral, a taxa média das exportações"

\footnotetext{
70 Diz Suplicy, "do lado da importação, as licenças de importação foram eliminadas e substituídas por vendas em leilão de licenças de câmbio. O órgão monetário (SUMOC) dividia as divisas estran geiras disponíveis em cinco diferentes categorias. Cada leilão correspondia a uma categoria específica e era sujeito a um prêmio mínimo. Algumas importações, no entanto, não estavam sujeitas ao sistema de leilão. Entre as mesmas contavam-se os itens importados pelos órgãos governamentais, trigo, papel para imprensa e derivados- de petróleo. A taxa de cambio para tais produtos era a oficial mais eventuais sobretaxas que poderiam ser fixadas pelo governo. Tais bens representavam cerca de 1/3 das importações totais. As demais importações foram classificadas em cinco categorias: a) insumos para a agricultura, certos produtos farmacêuticos e insumos para a indústria farmacêutica e alguns outros bens essenciais; b) matériasprimas essenciais (isto é, para algumas indústrias favorecidas, quase todos os fabricantes de produtos intermediários); c) outras matériasprimas "essenciais", tais como peças e equipamento de reposição (aqui também para as indústrias favorecidas); d) frutas frescas e outras peças e equipamentos de reposição; e) todos os outros produtos (a maioria dos bens de consumo final) . O mesmo viés na classificação que caracterizava o período de licenças (1947-53) continuou a existir durante o período de leilões de cambio (1953-57), variando, porém, a extensão dos efeitos nos preços. As taxas de câmbio mais baixas eram aplicadas às importações de bens de capital e insumos para a agricultura e algumas indústrias favorecidas; as segundas mais baixas, a outros bens de capital; e as terceiras, aos bens de consumo final".
} 
(SUPLICY, 1974). Esta taxa das exportações, para Delfim, por estar elevada, representava o principal motivo das exportações não crescerem durante a década de 1950. O ponto central é que se discutiria muito a reforma cambial para importações (querendo desvalorizá-la), o que traria junto aumento de preço - em outras palavras, aumento de custo -, sem se falar da reforma cambial para as exportações, as quais sofriam com o aumento de preço interno (ficando o câmbio ainda mais valorizado com a inflação) e com o câmbio mais apreciado (em patamar que garantisse importações subsidiadas para o desenvolvimento econômico).

\begin{tabular}{|c|c|c|c|c|c|c|c|}
\hline \multirow{2}{*}{ Ano } & \multicolumn{2}{|c|}{ Indice de quantidade } & \multirow{2}{*}{$\begin{array}{c}\text { Indice dos } \\
\text { termos de troca } \\
(T \text { de } T)\end{array}$} & \multirow{2}{*}{$\begin{array}{c}\text { Indice de poder } \\
\text { de compra das } \\
\text { exportaçбes } \\
\langle 1 Q X \times T \text { de } T\rangle\end{array}$} & \multicolumn{2}{|c|}{$\begin{array}{l}\text { Valores em bilhбes } \\
\text { de Cr3 de } 1939\end{array}$} & \multirow{2}{*}{$\begin{array}{l}\text { Coeficiente de } \\
\text { importacóes } \\
\text { (M/PID) } \\
\text { (\%) }\end{array}$} \\
\hline & $\begin{array}{c}\text { Importaf̧ões } \\
(I Q M)\end{array}$ & $\begin{array}{c}\text { Exportacōes } \\
(I Q X)\end{array}$ & & & $\begin{array}{c}\text { Importaçoes } \\
(M)^{-}\end{array}$ & $\begin{array}{c}\text { Produto interno } \\
\text { bruto (PIB) }\end{array}$ & \\
\hline 1920 & 90,6 & 55,2 & 118,8 & 65,7 & 4,4 & 21,3 & 20,7 \\
\hline $\begin{array}{l}1921 \\
1922\end{array}$ & 81,5 & 54,8 & 97,7 & 53,5 & 3,0 & 21,9 & 13,7 \\
\hline $\begin{array}{l}1922 \\
1923\end{array}$ & 77,0 & 58,3 & 161,3 & 93,8 & 3,8 & 22,8 & 16,7 \\
\hline $\begin{array}{l}1923 \\
1924\end{array}$ & 91,5 & 63,3 & 182,2 & 115,5 & 4,5 & 24,4 & 18,4 \\
\hline 1925 & 120,6 & 57,8 & 251,3 & 145,0 & 5,9 & 24,0 & 24,6 \\
\hline 1926 & $\begin{array}{l}138,4 \\
135,5\end{array}$ & 56,4 & 251,0 & 141,7 & 6,8 & 23,7 & 28,7 \\
\hline 1927 & $\begin{array}{l}135,5 \\
133,9\end{array}$ & 55,7 & $\begin{array}{l}247,5 \\
208,9\end{array}$ & 137,8 & 6,6 & 24,2 & 27,3 \\
\hline 1928 & $\begin{array}{l}153,9 \\
155,7\end{array}$ & $\begin{array}{l}61,8 \\
60,0\end{array}$ & $\begin{array}{l}208,9 \\
241,0\end{array}$ & 129,2 & 6,6 & 26,2 & 25,2 \\
\hline 1929 & 154,9 & $\begin{array}{l}60,0 \\
63,2\end{array}$ & $\begin{array}{l}241,0 \\
220,6\end{array}$ & 144,7 & 7,6 & 30,8 & 24,7 \\
\hline 1930 & 98,5 & $\begin{array}{l}63,2 \\
66,4\end{array}$ & $\begin{array}{l}220,6 \\
146,5\end{array}$ & 139,4 & 7,6 & 31,7 & 23,8 \\
\hline 1931 & 73,2 & $\begin{array}{l}66,4 \\
74,0\end{array}$ & $\begin{array}{l}146,5 \\
142,7\end{array}$ & $\begin{array}{r}97,2 \\
05,5\end{array}$ & 4,8 & $\begin{array}{l}30,6 \\
38,6\end{array}$ & $\begin{array}{l}15,7 \\
12,6\end{array}$ \\
\hline 1932 & 66,0 & $\begin{array}{l}74,0 \\
51,4\end{array}$ & $\begin{array}{l}142,7 \\
187,3\end{array}$ & $\begin{array}{r}105,5 \\
96,2\end{array}$ & 3,6 & $\begin{array}{l}28,6 \\
30,4\end{array}$ & $\begin{array}{l}12,6 \\
10,5\end{array}$ \\
\hline 1933 & 91,2 & $\begin{array}{l}51,4 \\
64,1\end{array}$ & $\begin{array}{l}187,3 \\
160,1\end{array}$ & $\begin{array}{r}96,2 \\
102,6\end{array}$ & 3,2 & & $\begin{array}{l}10,5 \\
13,6\end{array}$ \\
\hline 1934 & 95,8 & 69,7 & $\begin{array}{l}164,7 \\
104\end{array}$ & $\begin{array}{l}102,6 \\
114,9\end{array}$ & 4,5 & $\begin{array}{l}33,2 \\
35,2\end{array}$ & $\begin{array}{l}13,6 \\
13,3\end{array}$ \\
\hline 1935 & 92,5 & 74,1 & 115,4 & $\begin{array}{r}114,9 \\
85,5\end{array}$ & 4,7 & $\begin{array}{l}35,2 \\
34,7\end{array}$ & $\begin{array}{l}13,3 \\
13,0\end{array}$ \\
\hline 1936 & 95,8 & 80,1 & 119,9 & $\begin{array}{l}85,5 \\
96,0\end{array}$ & 4,5 & $\begin{array}{l}34,7 \\
39,4\end{array}$ & $\begin{array}{l}13,0 \\
11,9\end{array}$ \\
\hline 1937 & 114,8 & 77,2 & 124,7 & $\begin{array}{l}96,0 \\
96,2\end{array}$ & 4,7 & $\begin{array}{l}39,4 \\
40,7\end{array}$ & \\
\hline 1938 & 103,8 & 93,5 & 94,7 & $\begin{array}{l}96,2 \\
88,5\end{array}$ & 5,6 & $\begin{array}{l}40,7 \\
41,7\end{array}$ & $\begin{array}{l}13,8 \\
12,2\end{array}$ \\
\hline 1939 & 100,0 & 100,0 & 100,0 & $\begin{array}{r}88,5 \\
100,0\end{array}$ & 5,1 & $\begin{array}{l}41,7 \\
41,7\end{array}$ & $\begin{array}{l}12,2 \\
11,8\end{array}$ \\
\hline 1940 & 86,2 & $8 \mathrm{~J}, 1$ & 93,5 & $\begin{array}{r}100,0 \\
75,8\end{array}$ & 4,9 & $\begin{array}{l}41,7 \\
48,1\end{array}$ & $\begin{array}{r}11,8 \\
8,7\end{array}$ \\
\hline 1941 & 88,1 & 89,5 & 105,1 & $\begin{array}{l}75,8 \\
94,1\end{array}$ & 4,2 & $\begin{array}{l}48,1 \\
57,8\end{array}$ & $\begin{array}{l}8,7 \\
7,4\end{array}$ \\
\hline 1942 & 59,9 & 78,3 & $109, \mathbf{4}$ & $\begin{array}{l}94,1 \\
85,7\end{array}$ & 4,3 & $\begin{array}{l}57,8 \\
57,7\end{array}$ & $\begin{array}{l}7,4 \\
5,0\end{array}$ \\
\hline 1943 & 71,4 & 84,0 & 100,0 & $\begin{array}{l}85,7 \\
91,6\end{array}$ & 2,9 & $\begin{array}{l}57,7 \\
61,4\end{array}$ & $\begin{array}{l}5,0 \\
5,7\end{array}$ \\
\hline 1944 & 85,0 & 83,9 & 126,0 & $\begin{array}{r}91,6 \\
105,8\end{array}$ & 3,5 & $\begin{array}{l}61,4 \\
60,0\end{array}$ & $\begin{array}{l}5,7 \\
7,0\end{array}$ \\
\hline 1945 & 91,8 & 82,1 & 143,6 & $\begin{array}{l}105,8 \\
117,9\end{array}$ & 4,2 & $\begin{array}{l}60,0 \\
61,7\end{array}$ & $\begin{array}{l}7,0 \\
7,3\end{array}$ \\
\hline 1946 & 122,5 & 106,5 & 142,7 & $\begin{array}{l}117,9 \\
151,9\end{array}$ & 4,5 & $\begin{array}{l}61,7 \\
66,7\end{array}$ & $\begin{array}{l}7,3 \\
9,0\end{array}$ \\
\hline 1947 & 197,9 & 101,7 & 153,0 & $\begin{array}{l}151,9 \\
156,5\end{array}$ & 8,0 & $\begin{array}{l}66,7 \\
68,1\end{array}$ & $\begin{array}{r}9,0 \\
14,2\end{array}$ \\
\hline 1948 & 170,8 & 106,4 & 144,6 & $\begin{array}{l}156,5 \\
153,8\end{array}$ & 9,7 & $\begin{array}{l}68,1 \\
74,5\end{array}$ & $\begin{array}{l}14,2 \\
11,3\end{array}$ \\
\hline 1949 & 175,4 & 98,4 & 152,5 & $\begin{array}{l}153,8 \\
150,0\end{array}$ & 8,4 & $\begin{array}{l}74,5 \\
78,7\end{array}$ & $\begin{array}{l}11,3 \\
10,9\end{array}$ \\
\hline 1950 & 196,8 & 83,8 & 253,4 & $\begin{array}{l}150,0 \\
211,2\end{array}$ & 8,6 & $\begin{array}{l}78,7 \\
82,6\end{array}$ & $\begin{array}{l}10,9 \\
11,6\end{array}$ \\
\hline 1951 & 289,0 & 88,8 & 248,7 & $\begin{array}{l}211,2 \\
220,8\end{array}$ & 9,6 & $\begin{array}{l}82,6 \\
86,9\end{array}$ & $\begin{array}{l}11,6 \\
16,3\end{array}$ \\
\hline 1952 & 262,3 & 72,6 & 220,7 & $\begin{array}{l}220,8 \\
160,2\end{array}$ & 14,2 & $\begin{array}{l}86,9 \\
91,7\end{array}$ & $\begin{array}{l}16,3 \\
14,1\end{array}$ \\
\hline 1953 & 181,3 & 80,3 & 226,4 & $\begin{array}{l}160,2 \\
181,6\end{array}$ & $\begin{array}{r}12,9 \\
80\end{array}$ & $\begin{array}{l}91,7 \\
94,7\end{array}$ & $\begin{array}{r}14,1 \\
9,4\end{array}$ \\
\hline 1954 & 243,7 & 68,4 & 294,4 & $\begin{array}{r}181,6 \\
200,0\end{array}$ & 8,9 & $\begin{array}{r}94,7 \\
102,0\end{array}$ & $\begin{array}{r}9,4 \\
11,7\end{array}$ \\
\hline 1955 & 193,4 & 78,5 & 230,4 & $\begin{array}{l}200,0 \\
180,8\end{array}$ & 1,9 & $\begin{array}{l}102,0 \\
108,9\end{array}$ & $\begin{array}{r}11,7 \\
8,7\end{array}$ \\
\hline 1956 & 190,3 & 84,1 & 233,4 & $\begin{array}{l}180,8 \\
196,2\end{array}$ & 8,5 & $\begin{array}{l}108,9 \\
110,9\end{array}$ & \\
\hline 1957 & 231,9 & 79,6 & 233,6 & $\begin{array}{l}196,2 \\
186,0\end{array}$ & 9,3 & $\begin{array}{l}110,9 \\
118,6\end{array}$ & \\
\hline 1958 & 217,9 & 75,5 & 227,5 & $\begin{array}{l}186,0 \\
171,8\end{array}$ & 11,4 & $\begin{array}{l}118,6 \\
126,4\end{array}$ & $\begin{array}{l}9,6 \\
8,5\end{array}$ \\
\hline 1959 & 245,2 & 88,4 & 222,0 & $\begin{array}{l}171,8 \\
196,2\end{array}$ & 10,7 & $\begin{array}{l}126,4 \\
135,7\end{array}$ & $\begin{array}{l}8,5 \\
8,8\end{array}$ \\
\hline 1960 & 243,2 & 86,2 & 209,3 & $\begin{array}{l}196,2 \\
180,4\end{array}$ & 12,0 & $\begin{array}{l}135,7 \\
144,8\end{array}$ & $\begin{array}{l}8,8 \\
8,2\end{array}$ \\
\hline 1961 & 231,0 & 91,3 & 208,7 & $\begin{array}{l}180,4 \\
190,5\end{array}$ & 11,9 & $\begin{array}{l}144,8 \\
155,3\end{array}$ & \\
\hline 1962 & 233,5 & 84,6 & 195,0 & $\begin{array}{l}190,5 \\
164,9\end{array}$ & 11,3 & & $\begin{array}{l}7,3 \\
7,0\end{array}$ \\
\hline 1963 & 226,6 & 96,7 & 190,3 & $\begin{array}{l}164,9 \\
184,0\end{array}$ & 11,4 & $\begin{array}{l}1633,6 \\
166,3\end{array}$ & $\begin{array}{l}7,0 \\
6,7\end{array}$ \\
\hline 1964 & 196,4 & 82,9 & 230,1 & $\begin{array}{l}184,0 \\
190,8\end{array}$ & 11,1 & & $\begin{array}{l}6,7 \\
5,6\end{array}$ \\
\hline 1965 & 162,6 & 82,9 & 243,6 & $\begin{array}{l}190,8 \\
201,9\end{array}$ & 9,6 & $\begin{array}{l}171,4 \\
178,1\end{array}$ & $\begin{array}{l}5,6 \\
4,5\end{array}$ \\
\hline 1966 & 210,9 & 94,3 & 223,3 & $\begin{array}{l}201,9 \\
210,6\end{array}$ & 8,0 & $\begin{array}{l}178,1 \\
184,1\end{array}$ & $\begin{array}{l}4,5 \\
5,6\end{array}$ \\
\hline 1967 & 233,4 & 82,9 & 239,1 & $\begin{array}{l}210,6 \\
198,2\end{array}$ & 10,3 & $\begin{array}{l}184,1 \\
193,2\end{array}$ & $\begin{array}{l}5,6 \\
5,9\end{array}$ \\
\hline & & & & & 11,4 & 193,2 & 5,9 \\
\hline
\end{tabular}

Fonte: Simonsen Mario Henrique. Bruail s002. Rio de Janeiro, APEC Bditora, 1972. p. 96-8.

De acordo com Huddle (1972), o valor total das exportações brasileiras caiu $10 \%$ no período entre 1953 e 1957 . As exportações de café teriam tido um decréscimo de $20 \%$ (enquanto a participação africana aumentara em 1/3), e as exportações de cacau, açúcar e 
algodão reduziram-se em 15\% (HUDDLE, 1972). Se se tem em mente que já em 1952 o Brasil se encontrava com problemas de obtenção de divisas, e que o programa de substituições de importações só aumentou, começa-se a desenhar o tamanho da restrição externa que se desenhava no Brasil em 1957. Além disso, o preço do café, que no primeiro lustro da década era favorável, passa a não mais sê-lo, restringindo ao Brasil a tradicional alternativa por meio da expansão da exportação desse produto, como forma a compensar a queda de preços. Ainda, entre 1953-57, 20\% do total da receita governamental advinha do diferencial de taxas de exportação e importação, sendo que aquelas havia sido (em média) metade da praticada por esta (HUDDLE, 1972, p. 156). Assim, a restrição externa - preocupante em 1952 - torna-se crescentemente alarmante. E é, por isso, que imaginamos que essa preocupação vem crescendo nos artigos de Delfim com o passar do tempo. Se era pouca em 1952, e passa a ser central nos artigos após 1955.

Para Suplicy (1974) - assim como para Delfim - este sistema de taxas múltiplas (implementado em 1953 e mantido até 1960) não tinha em si intrínseco papel de desincentivo das exportações. Pelo contrário, os desincentivos às exportações teriam sido feitos pelo governo de forma programática, com retardo no reajuste das taxas cambiais de exportação, pois o saldo das operações cambiais disponível no Fundo de Ágios ${ }^{71}$ diminuía em razão de cada ajustamento da taxa cambial de exportação, reduzindo, dessa forma, o dinheiro disponível para o governo (SUPLICY, 1974, p. 43). Além disso, “impediu-se uma remuneração mais alta na exportação de alguns bens para que não ocorressem aumentos nos preços internos” (SUPLICY, 1974, p. 43). Entende-se, assim, que para Delfim, seria necessário i) não desvalorizar o câmbio para importações essenciais, evitando "que os demais itens componentes do custo de produção tende[ssem] a subir" (DELFIM NETTO, 1957b, p. 42); e, ii) desvalorizar o câmbio para os produtos de exportação (com exceção do café).

Por outro lado, Delfim criticava a criação de indústrias de bens de luxo que estariam sendo incentivadas a serem trazidas para o Brasil pela excessiva proteção que estava sendo projetada para elas. A razão disso, para o autor, estaria no problema do consumo conspícuo das classes mais altas da sociedade, as quais "tendem a adotar os padrões de

\footnotetext{
${ }^{71}$ De acordo com Leopoldi (2002, p. 66), o Fundo de Ágios fora criado em 1953 juntamente com a criação da Sumoc 70, e representava o excedente pago pelos importadores, "que custeava despesas importantes do Governo, e representou mais outra reforma fiscal importante e representou mais outra reforma fiscal disfarçada, como o foram os demais fundos criados no período Vargas".
} 
consumo e fruição dos países mais desenvolvidos" (DELFIM NETTO, 1957b, p. 32). Este mercado "das classes mais altas" era ampliado devido à inflação daquele momento, na qual tenderia "a haver uma maior concentração da riqueza e os ganhos monetários de algumas classes da economia tendem a crescer muito rapidamente" (DELFIM NETTO, 1957b, p. 32). Seria o caso "dos automóveis de passeio e de alguns produtos da quinta categoria" (DELFIM NETTO, 1957b, p. 32-33), pois uma taxa "ad-valorem" de 150\% criava maior incentivo e condições favoráveis para essas indústrias virem se instalar, do que uma siderurgia, com uma tarifa de 10\% "num determinado tipo de aço" (DELFIM NETTO, 1957b, p. 33). É, também, dessa opinião Suplicy (1974, p. 43) ao dizer que "a produção nacional de alguns bens era desencorajada, ao passo que se estimulava a produção de bens de consumo de luxo altamente protegidos".

Para Delfim, a proteção às indústrias substituidoras de importação oneraria as industrias exportadores. "Em outras palavras, a elevação dos custos internos criada pelo deslocamento de fatôres das indústrias de exportação paras as de substituição das importações tende a elevar o nível de custo da exportação" (DELFIM NETTO, 1957b, p. 31). Critica-se o favorecimento das indústrias para o mercado interno que oneram aquelas que se voltariam ao mercado externo. Ainda pior, ao se proteger muito os produtos de luxo, poder-se-iam criar incentivos para a implementação de uma fábrica nacional desses produtos ao invés da implementação de uma fábrica mais importante do ponto de vista do desenvolvimento nacional. Um motivo a mais para a defesa do planejamento econômico, ponto melhor discutido no capítulo quarto deste trabalho.

\subsection{Inflação}

\subsubsection{Inflação e o desequilíbrio externo}

O Problema do comércio internacional, para Delfim, e a inflação estariam intimamente ligados, sendo, inclusive, difícil de separar a explicação dele para um ponto, ou para outro, sem correr o risco de se perder o raciocínio. Para tanto, expõem-se os pontos a seguir ligados com a argumentação da mudança de estruturas que causariam os desequilíbrios externos. O problema do desequilíbrio cambial brasileiro teria dois elementos embutidos; i) a inflação brasileira (com o câmbio fixo) dificultaria a exportação "principalmente em função da transferência de rendimentos, que se estabelece entre o setor exportador e o importador” (DELFIM NETTO, 1955a, p. 09). Em vista desse quadro, a desvalorização da moeda não resolveria a situação porque "cada aumento da procura interna alimentado 
pela criação de meios de pagamento leva a uma nova desvalorização" e, pior, "à medida que se deprecia a taxa cambial, avolumam-se os lucros dos exportadores [de café] e crescem os preços das importações” (DELFIM NETTO, 1955a, p. 09). Em outras palavras, a desvalorização no caso brasileiro beneficiaria os cafeicultores (que, como será exposto no capítulo 3, são aqueles que se beneficiavam das desvalorizações na década de 1950), em detrimento daqueles que importavam maquinário e/ou equipamentos para a indústria. É interessante notar o editorial da "Revista dos Mercados" de 1954, a qual diz: "Mas, com o cruzeiro perdendo o seu poder aquisitivo cada mês que passa e o preço dos inseticidas, fertilizantes, braço rural e aluguel das terras acompanhando a alta vertiginosa do café, como poderemos obter um custo barato do algodão?” (REVISTA DOS MERCADOS, 1954, p. 04). A única solução, nesse caso, seria a de "estabelecer o controle cambial a uma taxa que se julga será a de equilíbrio e iniciar imediatamente o combate à inflação através das medidas monetárias e fiscais aconselháveis" (DELFIM NETTO, 1955a, p. 09).

Já o segundo elemento do desequilíbrio externo brasileiro seria estrutural:

Quando, por exemplo, o desequilíbrio é proveniente do desenvolvimento do parque industrial, [pois] aumentam as necessidades de equipamentos, combustíveis, etc. e, ao mesmo tempo, deslocam-se fatores anteriormente aplicados pelo aumento do mercado interno e pelo aumento das necessidades das novas indústrias (...) (DELFIM NETTO, 1955a, p. 09).

Por outro lado, esse desequilíbrio causado por essa nova estrutura industrial não poderia ser resolvido pela desvalorização da moeda, a qual seria apenas transformada em inflação. Assim, "devemos encarar seriamente o problema do aumento de nossas exportações, incentivando a diversificação dos nossos produtos exportáveis" (DELFIM NETTO, 1955a, p. 10).

O mecanismo de transformação da desvalorização em maior inflação, geraria "uma pressão sobre o nível de salários, podendo iniciar-se, assim, a espiral preços-salários, característica da inflação". A elevação do custo de vida tornaria "necessário conceder um aumento de salários, sob pena de agravar a distribuição de renda”. (DELFIM NETTO, 1955a, p. 11). Contudo, o aumento de salários não poderia ser concedido em um nível 
que compensasse a desvalorização feita, porque, caso assim fosse feito, haveria um novo aumento de preços que exigiria uma nova desvalorização ${ }^{72}$.

O nível de preços e a taxa de câmbio reagiriam um sobre o outro, de forma a reduzir violentamente o valor da moeda nacional. Na presença de um processo dessa natureza, é inevitável uma intervenção direta do governo no sentido de eliminar a causa do desequilíbrio (DELFIM NETTO, 1955a, p. 08)

Vê-se como, para Delfim, o problema do câmbio e o da inflação seriam ligados, sendo necessário combatê-los conjuntamente. Além da inflação, o processo de industrialização brasileira teria sido a acompanhado da necessidade crescente de importação "de matéria prima estrangeira e, para sua conservação, da importação de novos equipamentos”. Essa necessidade se deu ainda mais, porque o incentivo que se criou para a industrialização no Brasil não teria sido para industrias de bases, e sim, para indústrias de produção de bens finais (ou de substituição de importações), o que exigiria ainda maior dependência do setor externo. Por isso, seria urgente incentivar essas atividades exportadoras nem que fosse por meio de "taxas diferenciais". Mas, deveria se objetivar ter "em longa duração o estabelecimento de um sistema que automàticamente equilibre a balança de pagamentos, deixando livre as transações” (DELFIM NETTO, 1955a, p. 12).

Delfim não comenta como seria um sistema que "automaticamente equilibr[asse]" a balança de pagamentos. Contudo, quando esteve à frente da Pasta da Fazenda introduziu um sistema de "mini-desvalorizações", o qual consistia em introduzir um sistema automático de desvalorização da moeda brasileira em relação a inflação daqui e a dos EUA, numa tentativa de manter sempre o "câmbio real" igual ${ }^{73}$. O "câmbio-livre", outra alternativa, como comentado, não dependeria somente de o país mantê-lo, pois teria sido imposto a praticamente todos os países após a "grande depressão e da desconfiança que se instaurou no mundo" e "pràticamente nenhum país pôde manter-se fora de uma ou de outra forma de controle" (DELFIM NETTO, 1955a, p. 10).

\subsubsection{Inflação como questão distributiva}

Delfim (1958a) afirma que inflação é um descompasso entre a quantidade ofertada de um determinado produto em certo tempo, e o desejo de consumir - ao nível de preços vigentes - mais do que foi ofertado. A única solução seria, portanto, um aumento do preço, ou um

\footnotetext{
${ }^{72}$ Diz Delfim (1955a, p. 08) "o desenvolvimento da inflação atuaria novamente sobre as curvas de oferta e procura de divisas, levando a uma nova desvalorização, que conduziria a um novo aumento do custo de vida e assim por diante".

${ }^{73}$ Para mais informações sobre o sistema de "mini-desvalorizações” cambiais, c.f Suplicy (1974).
} 
aumento da oferta. Para ele, caso haja desuso dos fatores da economia, um aumento da oferta, não geraria inflação. Ao contrário, quando os fatores vão se encaminhando para seu total uso, um aumento cada vez maior do preço deverá existir, para incentivar um montante igual do aumento da produção. Argumenta-se à la Keynes: se existe capacidade ociosa de produção, o governo intervindo e contratando pessoas para realizarem algum trabalho, aumentaria a procura global, e melhoraria a renda. "Notemos que, a curto prazo, quase o mesmo resultado poderia ser obtido se o governo, em vez de construir uma estrada de rodagem (um investimento de claros benefícios), tivesse empregado os trabalhadores para fazerem e taparem buracos" (DELFIM NETTO, 1958c, p. 92). Entretanto, se a economia já se encontrasse em plena capacidade de produção, a intervenção governamental somente desviaria fatores de produção de um lugar ao outro. Assim sendo, parte do pressuposto de que os assalariados conseguem pelo menos manter a sua participação na renda, por terem "força política o suficiente" (DELFIM NETTO, 1958d, p. 92). E os empresários por calcularem uma porcentagem fixa do retorno sobre o custo.

Quando, por outro lado, não se tem capacidade ociosa, o aumento do preço vira um jogo de empurra-empurra das partes envolvidas (assalariados, empresários e governo). O problema seria, nesta questão distributiva, agravado caso o governo "roubasse" parte do produto nacional dos empresários

O fenômeno atinge os seus aspectos mais graves quando o setor que deseja aumentar a sua participação no produto nacional real é o próprio Govêrno, porque neste caso não existe pràticamente nenhum limite às suas pretensões e êle pode impor à coletividade um prolongado e pernicioso processo inflacionário que corrói todo o sistema econômico e dissolve a escala de valores morais (DELFIM NETTO, 1958a, p. 141-142, grifos meus).

A inflação é um fenômeno confortável para o governo, porque acomodaria bem as disputas internas da economia pelo produto interno;

Os empresários acostumados a uma política de compra que dá sempre certo e a calcular uma margem de lucro fixa como porcentagem do custo, resistem à sua redução; o alto nível de emprego dá condições cômodas para os empregados resistirem a redução do salário real, isto é, os empregado têm condições para impedir que o salário cresça mais lentamente do que o índice de custo da vida; o Governo, (...) pode continuar calmamente em sua política de déficits orçamentários (...) pois a inflação dá uma impressão de prosperidade geral (DELFIM NETTO, 1958a, p. 142, grifos meus). 
O governo, administraria o caos político instaurado à época com o governo de coalizões que representaria o governo de Juscelino, tendo na inflação uma alternativa "cômoda" que geraria uma “impressão de prosperidade geral", mas também, é grande causador desse processo, por ter incentivado a criação - por meio do processo de substituição de importações - de "industrias artificiais" que teriam se acomodado:

Como sub-produto dessa política, estabelecemos uma altíssima taxa de produção para a indústria nacional e impedimos o funcionamento do sistema de preços no seu papel orientador dos investimentos. Paralelamente, tôda uma política trabalhista de caráter utópico criou condições altamente vantajosas de emprego nos centros urbanos, quando comparada com as do campo. Foi possível, portanto, graças a esses dois fatores (maiores salários industriais como consequência de um altíssimo grau de proteção e maior amparo da legislação trabalhista) transferir maciçamente a mão-de-obra da agricultura para os centros urbanos, condição básica para a ampliação da produção industrial (DELFIM NETTO, 1958a, p. 147).

Ao se proteger a indústria, distorceram-se os preços relativos, impedindo os reinvestimentos na agricultura, ou nas atividades exportadoras, acarretando o aumento do salário real urbano (salário definido pelas indústrias produtoras ao mercado interno), que acabou reverberando para as atividades de exportação. Além disso, critica uma "política utópica" de aumento de salários, que estaria roubando mão-de-obra da agricultura.

Para corroborar seu argumento, cita Turroni ([1931] 1937) ${ }^{74}$ :

A respeito é interessante a seguinte observação de Turroni: 'Na fase mais aguda da inflação, a Alemanha ofereceu o grotesco e ao mesmo tempo trágico espetáculo de um povo que em vez de produzir alimentos, fazendas, sapatos e leite para seus próprios filhos, estava acabando as suas energias fabricando máquinas ou construindo fábricas' (DELFIM NETTO, 1958a, p. 144)

Inclusive, Delfim continua defendendo que os empresários deveriam rever suas taxas de lucro sobre seus custos:

Seria preciso que os empresários revisassem as suas bases de cálculo e deixassem de acreditar que existe alguma coisa mágica na regra prática de fixar os seus preços de venda acrescentando $30 \%$ ao custo dos produtos. Uma redução dessa margem de mesmo $5 \%$ teria efeitos ponderáveis sôbre o nível de preços (DELFIM NETTO, 1958a, p. 145).

Aos industriais, como salientado, defendidos por políticas do governo, era-lhes garantido o mercado interno de tal forma que esse cálculo lhes fosse permitido. Delfim está

\footnotetext{
${ }^{74}$ Não explicita, mas Delfim se referia ao livro Economia da Inflação de Turroni.
} 
atacando a política, em sua visão, demagoga e apressada, de tentar coadunar as demandas políticas internas, a cada hora uma, e sempre a curto prazo. Portanto, “A única alternativa que nos resta, talvez, é pôr em execução uma cuidadosa e bem equilibrada política de combate à inflação" (DELFIM NETTO, 1958a, p. 145)

\begin{tabular}{|lrrrr|}
\hline & $\begin{array}{c}\text { Redimento } \\
\text { Nacional }\end{array}$ & Salário & Lucro & Renda \\
\hline Equilíbrio & & & & \\
inicial & 100 & 65 & 20 & 15 \\
Déficit & 110 & 65 & 30 & 15 \\
$1^{\circ}$ período & 118,9 & 71,5 & 32,4 & 15 \\
$2^{\circ}$ período & 126,9 & 77,3 & 34,6 & 15 \\
$3^{\circ}$ período & 134,1 & 82,5 & 36,6 & 15 \\
Equilíbrio & & & & \\
final & 203 & 132 & 55 & 15 \\
\hline
\end{tabular}

Figura 2: Dinâmica do processo de redistribuição da renda nacional (DELFIM NETTO, 1958c, p. 73)

Delfim, inclusive, destrincha os preços das mercadorias em três fatores: salário, renda e lucro. O último, como sendo residual. Dito em outros termos, o preço de mercado de um bem é todo distribuído, durante o próprio processo de produção, como remuneração das classes que participaram da sua produção: os trabalhadores recebem seu salário, o grupo dos rentistas a sua renda, e o empreendedor o seu lucro. "O lucro é a única remuneração residual, de maneira que as flutuações de preços de mercado a curto prazo se refletem diretamente sôbre êle" (DELFIM NETTO, 1958d, p. 73)

Para Delfim, portanto, teríamos que a disputa pela participação na renda das classes, estaria sendo 'ganha' por aqueles que dependiam dos salários e dos lucros, sendo distribuída a parte dos rentistas a eles. Com a espiral de preços funcionando, e o câmbio mantido fixo as exportações tendem a diminuir. Em outras palavras, a procura pelos produtos brasileiros cairia. Então, se houvesse um aperto monetário, poder-se-ia ter tanto um aumento, quanto uma diminuição da procura brasileira.

Se os assalariados conseguem elevar a sua remuneração à custa do rendimento dos empreendedores, provavelmente a procura real tenderá a crescer, porque êles gastarão uma parcela maior do rendimento adicional, que conseguiram obter à custa da classe empresária. Êste movimento e a redução das exportações têm sentido contrário e 
poderão, eventualmente, compensar-se (DELFIM NETTO, 1958d, p. 96)

A "procura real tenderá a crescer", salienta-se que é a procura interna que poderá ser compensada pela "redução das exportações". Há, aqui, implícito uma briga entre se produzir para o mercado interno, ou para o externo. A distribuição de renda (advinda com a elevação da remuneração dos assalariados) aumentaria a procura real o que poderia compensar a queda da exportação; contudo é só com a exportação que se permite entrada de divisas no país.

Caso houvesse um aperto monetário, como forma de segurar a inflação, atingiria somente os empresários, que diminuiriam o investimento, diminuindo, sucessivamente, o nível de atividade econômica. A única forma, de se manter a atividade econômica, nesse caso, seria com o governo aumentando as participações no produto. A questão central é que, para Delfim, os sindicatos eram muito fortes, assim como a capacidade dos empresários em reajustarem seu lucro, dado o custo. De tal maneira que ambos continuariam lutando pela sua parcela, sem nunca saírem do lugar. Com esta intervenção do governo, contudo, ter-se-ia menor investimento (e, portanto, queda na renda real), a não ser com um crescimento do governo. Por isso, podemos inferir, que aperto monetário sem outras alternativas causaria recessão, ou aumento da participação no produto do governo (que ocuparia o lugar do empresário no investimento), sem, contudo, resolver a inflação.

(...) e se mesmo por razões de ordem psicológicas as classes empresárias se virem forçadas a diminuir o nível de investimentos e, consequentemente, do rendimento nacional real e do volume de emprego. Se dentro dessa hipótese, o govêrno desejar manter o nível de emprego, êle terá de aumentar correspondentemente os investimentos públicos, o que numa larga medida significa uma ampliação ainda maior de sua esfera de ação dentro da economia. (DELFIM NETTO, 1958 d, p. 96, grifos meus)

Conclusão: a única forma saudável de acabar com a inflação, sem colocar a economia em recessão, seria primeiro os assalariados aceitarem uma redução na sua participação da renda (pois esta não estaria de acordo com a produtividades deles), para assim, poder-se colocar a economia de "volta aos eixos", e quem sabe, direcionar maior parte da produção ao mercado externo, qualquer outra alternativa levaria a uma recessão ou maior participação do governo na economia, em um constante crescente. Talvez, em um momento de democracia, essa política não pudesse ser feita. Ainda mais, em um governo com pouco apoio, como era o JK, que, na perspectiva de Delfim, precisaria sempre estar fazendo políticas de curto prazo, como tentativa de agradar cada classe social. 


\subsection{Síntese do capítulo}

Evidencia-se a insatisfação de Delfim com as políticas de Industrialização por Substituição de Importações (doravante, ISI) (DELFIM NETTO, 1957b). No nosso entender, esse é o cerne das questões para Delfim. Para ele, o "desenvolvimento orgânico" (DELFIM NETTO, 1953d, p. 12) não acontecera no Brasil, pois a economia brasileira ainda estaria dependente do estímulo externo para se desenvolver. Essa indústria, portanto, "estrangulava" o balanço de pagamentos, tornando o desenvolvimento mais dependente, e não orgânico.

A questão central não era proteger ou não a indústria, ou proteger ou não a agricultura ou a cafeicultura. Delfim não se apresenta como um defensor do livre mercado a qualquer custo. Não somente porque existiam muitas distorções que impediam que as "leis ricardianas de vantagem comparativa valessem", como ele percebia uma desigualdade entre países já desenvolvidos e países que ainda não o foram. Existe, em seu pensamento, processos históricos que não podem ser repetidos. As diferentes revoluções industriais, exemplo por ele mesmo utilizado, são explícitas nesse sentido. O livre-cambismo, assim como não fora praticado a todo momento por todos os países, também não poderia ser praticado sem uma análise das condições históricas.

Por outro lado, caso deva-se interferir no mercado, e de certa forma guiar o desenvolvimento, para o autor, o governo - no período, Juscelino Kubistchek - estava agindo de forma completamente equivocada. Ao invés de guiar o Brasil para o desenvolvimento, estava guiando o Brasil de forma a conseguir manter-se no poder. Suas atitudes simplesmente refletiam ou "improvisavam", para atender a cada demanda política em cada tempo diferente. O planejamento - na visão de Delfim - era posto subordinado às 'intempéries' das reclamações de diferentes grupos. Nesse ponto, então, estaria Delfim sendo partidário a algum grupo político específico? Tentemos, primeiro entender, quais grupos estaria ele criticando.

Suas críticas mais conhecidas são contra as compras de café que o governo ainda realizava. Para o Delfim aqui tratado, isso não era um erro per se; algo de condenável $a$ priori. As compras poderiam até serem mantidas, caso houvesse algum cenário em que isso se sustentasse. Entretanto, no momento, as compras periódicas, e de certa forma, previsíveis, serviam apenas para sustentar a produção internacional - algo explícito em suas conclusões -, mas também, sustentava os produtores menos produtivos. Esses, ao 
venderem suas sacas, partilhavam dos ganhos em divisas estrangeiras junto aos grandes produtores. Ao contrário do que comumente se repete, para Delfim, as compras não estariam socializando as perdas dos produtores; não, pelo menos dos grandes. E sim, agravando-as.

A compra, por garantir uma tendência de alta na oferta da rubiácea - com um hiato temporal de três a quatro anos - estaria constantemente diminuindo as receitas dos grandes produtores. A compra do café, nessa visão, socializa os lucros com os pequenos produtores, que conseguiam manter-se no mercado. E retardava o movimento de concentração da produção no campo, e os benefícios produtivos advindos desse movimento. Como Delfim salienta sempre em seus textos, havia tecnologia disponível para implementar-se no campo uma 'revolução' na produção, de tal forma que com 1/3 dos insumos, produzir-se-ia a mesma quantidade em poucos anos. Liberando, assim, importantes recursos para outras atividades da economia.

Ademais, ao invés de utilizar o máximo das exportações para garantirem a entrada de divisas, e assim, conseguir-se manter o processo de desenvolvimento tecnológico brasileiro para aumentar a produtividade dos setores, as exportações eram "abocanhadas" pelo governo para sustentarem uma indústria "atrasada", e "mal acostumada" que não conseguia ser competitiva para manter preços que não pressionassem a inflação, a reserva de mercado, inclusive, garantia que os empresários - ao calcularem o lucro como uma porcentagem dos custos - sempre conseguiam manter a sua parcela na renda nacional, realimentando o processo inflacionário.

Delfim é explícito ao dizer que nenhum país deva manter sua pauta de exportação apenas em um produto, ou em poucos produtos agrícolas ${ }^{75}$. Fica explícito que se deve diversificar as pautas de exportação, para se conseguir manter o desenvolvimento. Aumentar as exportações de produtos não agrícolas, sempre foi seu libelo. E que grupos de empresários conseguiriam aumentar as exportações? Somente os mais produtivos. Somente os grandes, e, como a maioria das multinacionais do período vinham para suprir o mercado interno, então, talvez, somente os grandes industriais nacionais, seriam os únicos que cumpririam essa descrição. ${ }^{76}$

\footnotetext{
${ }^{75}$ Ver, por exemplo, Delfim Netto (1953d).

76 Isso não o torna um antagonista do "capital internacional". Ao contrário, caso esse tivesse a funcionalidade de aumentar a entrada de divisas externas no Brasil, seria bem-vindo.
} 
Dessa forma, é primarismo acreditar que as teses de Delfim eram neutras. Elas protegiam e incentivavam um certo grupo político. Os grandes capitalistas brasileiros a tornarem-se mais produtivos. Tenta, a todo momento, identificar o que seria o as atitudes corretas para o desenvolvimento do país, com aquelas as quais também seriam, de forma intencional ou não, as melhores atitudes para o desenvolvimento dos industriais mais modernos. 


\section{Capítulo 3: A propósito do café}

\subsection{Introdução}

Pretende-se, neste capítulo, expor os principais argumentos contidos no livro "O Problema do Café no Brasil" ([1959] 2009) e mostrar que este problema tinha como causa principal a manutenção de uma elite no poder cujos interesses acabaram por atrasar o desenvolvimento no país. Delfim, como exposto no capítulo segundo desta dissertação, logo cedo se ligou aos grupos produtores de algodão (e, também, às manufaturas que necessitavam desta matéria-prima), por meio da Bolsa de Mercadorias, produto que teria representado, para o autor, a alternativa mais avançada do ponto de vista da promoção do desenvolvimento econômico no país, ao invés de se ter mantido a elite cafeicultora por tanto tempo.

Em seguida, comparam-se as diferentes perspectivas contidas no livro de Delfim ([1959] 2009) com aquelas que se entende estarem contidas no livro "Formação do Brasil Econômico", de Furtado ([1959] 2007). Essa comparação tem em mira a discussão que será feita no capítulo quarto desta dissertação, em que será mostrado como Delfim, em alguns momentos, estava dialogando diretamente com Furtado, em especial, ao se tratar de estratégias para o desenvolvimento econômico e seus problemas. O diagnóstico de Furtado seria que o desenvolvimento necessitaria de um maior estímulo da demanda, ou que a estagnação aconteceria por uma falta de consumo. A solução poderia ser, entre outras, uma maior participação política dos consumidores, para que a renda lhes fosse distribuída. Para Delfim, o problema essencial que impossibilitaria o desenvolvimento seria o persistente défice no balanço de pagamentos, o que exigiria um maior controle das atividades econômicas (tanto por parte dos consumidores como dos investidores) por um governo de força, que conduziria parte da produção à exportação, conseguindo ser superada a restrição externa para o desenvolvimento.

\section{2 o Café, o Desenvolvimento Econômico e o Atraso}

\subsubsection{O debate}

A primeira vez que se tem notícia do plantio de café no Brasil foi por meio das sementes trazidas por Francisco de Melo Palheta, que as teria plantado no Pará, em $1727^{77}$.

\footnotetext{
77 Para mais informações sobre a história do café no Brasil, conferir, e.g., Taunay (1943); Delfim Netto (1973); Fausto (1975); Guarnieri (1979); Stolcke (1986); Bacha (1992).
} 
Contudo, foi somente no século seguinte que o produto ganhou força e se tornou a principal commodity de exportação brasileira.

Indubitavelmente, o café foi importante para o desenvolvimento econômico brasileiro, mesmo que a forma pela qual tenha se dado esse desenvolvimento seja um assunto em disputa. Houve uma controvérsia extensa sobre o assunto ao longo de século XX, disputada principalmente entre economistas, a qual suscitou uma ampla sorte de argumentos e pontos de vista. O debate tomou força após Peláez, em 1968, ter feito uma crítica aos argumentos de Furtado, contidos, principalmente, no livro "Formação Econômica do Brasil" ${ }^{17}$. Peláez ataca esta interpretação que associa principalmente a Furtado (em especial aos capítulos 30 a 32 daquele livro) ${ }^{79}$, a qual diria que a atuação do governo em 1930, em resposta à crise, com expansão de crédito e défice orçamentário, fora fundamental para a recuperação brasileira. Esta tese - ainda na interpretação que Peláez faz- afirmaria que a proteção do café, de forma intencional, teria sustentado a demanda agregada, criando um mercado para a indústria nascente nacional.

Este razoamento, que Peláez atribui à "escola estruturalista”, e que tem como principal antagonista Furtado, recebeu do autor a alcunha de "Choques Adversos". O ponto principal que ele percebe desta interpretação (associada ao Furtado e à Escola Estruturalista) é a acentuação da importância da Grande Depressão no Brasil, momento no qual a economia do país teria sofrido verdadeiramente mudanças em sua estrutura. A reação do governo à Grande Depressão teria sido importante por três argumentos principais interdependentes. O "argumento da recuperação", o "argumento da transferência" e o "argumento dos reajustes econômicos".

O primeiro argumento (na interpretação de Peláez sobre a "tese estruturalista"), Peláez classifica como de "política contracíclica keynesiana". As compras e incinerações financiadas por criação de moeda (défices governamentais), teriam permitido que a renda nacional do Brasil não declinasse tanto quanto no exterior (mantendo a renda do setor cafeeiro alta) e que a economia voltasse ao pleno emprego. O segundo focaria na transferência de renda dos produtores cafeeiros para a atividade manufatureira voltada ao mercado interno. Ocorre que, ao se diminuir a rentabilidade do café e aumentar a

\footnotetext{
${ }^{78} \mathrm{O}$ primeiro texto de Peláez escrito nesse sentido foi publicado em 1968. Contudo, mais seis textos nessa toada crítica se seguiram (1969, 1970a, 1970b, 1971a, 1971b, 1972).

${ }^{79}$ Mas não restringe apenas ao Furtado à crítica. Às vezes, se refere aos "estruturalistas" como escola, às vezes contra Werner Baer (1968), e contra uma monografia escrita por Wirth (1970).
} 
lucratividade das manufaturas (pois os produtos importados aumentaram de preço), teria havido um incentivo para que se investisse nas manufaturas. O mercado interno haveria, pois, sido mantido, pelas políticas de compras/destruições do café que teriam conservado os salários dos trabalhadores. $\mathrm{O}$ argumento da transferência, finalmente, atribuído mais a Baer do que propriamente a Furtado, enunciaria que, com as renegociações das dívidas dos fazendeiros, teria sido criado um "reajuste econômico" dos produtos agrícolas, o que teria constituído uma fonte extra dos efeitos multiplicadores da renda daquele setor. A partir desse diagnóstico, algumas receitas para o desenvolvimento da economia brasileira seriam advogadas, tais como: i) financiar o desenvolvimento econômico pela formação do défice; ii) protecionismo quase total; iii) socialização da indústria, a qual seria controlada pela "velha oligarquia dos plantadores de café" (Peláez, 1970a) a partir da década de 1930.

O razoamento de Peláez contra esta interpretação (chamada por ele de "estruturalista" ou de interpretação de Furtado) é argumentar que: i) não haveria política de expansão monetária no governo $\operatorname{Vargas}^{80}$, e que todas as políticas teriam sido seguidas em harmonia com a de conselheiros banqueiros estrangeiros. A compra/destruição de café fora financiada por impostos ou por empréstimos externos; ii) não teria havido transferência de renda do setor cafeeiro para o setor urbano/industrial. Os cafeicultores, vendo a oportunidade, teriam investido em plantações de algodão, produto que teve sua participação nas exportações altamente crescidas durante o período; iii) o produto interno real teria diminuído muito, só se recuperando em valores após 1939; iv) que a produção de ferro, aço, cimento interna realmente teria aumentado, contudo, o consumo total desses produtos teria diminuído durante toda a década; v) boa parte dos investimentos nas indústrias havia sido feita por grupos externos ou antes de 1930.

Fonseca e Salomão (2017, p. 89), ao analisarem o debate, classificam essa análise de Peláez como a "reação liberal" à interpretação Cepalina. É sempre complicado classificar um autor; Peláez era um grande crítico do que chama da "ortodoxia monetária brasileira", em especial a de Getúlio Vargas. A principal crítica de Peláez parece ser não somente que houve indústrias antes de 1930, e que a crise externa não teria sido o grande motivador das mudanças estruturais do Brasil, mas sim que as políticas monetárias e fiscais do governo Vargas foram recessivas. Que não teria havido criação de moeda e, sim, que teria

\footnotetext{
${ }^{80}$ Peláez diz que apenas a partir de 1937 o governo começou a gastar nesse sentido de criação de moeda, mas apenas para reaparelhar as forças armadas (Peláez, 1971b, p. 82)
} 
havido uma forte intenção de se manter o orçamento equilibrado. Peláez diz que J. M. Whitaker e Oswaldo Aranha, ambos ministros de Vargas, aprofundaram a crise com "seus esforços para alcançar o equilíbrio orçamentário, na pior crise jamais experimentada pelo mundo, [situando-se] como o mais drástico exemplo de má condução dos assuntos financeiros na história econômica do Brasil” (PELÁEZ, 1970a, p. 186). Para o autor, o problema brasileiro sempre fora a falta de crédito no país, esta falta de crédito não teria acontecido à toa, mas, sim, porque os Ministros da Fazenda e Presidentes do Banco do Brasil, de 1894 a 1945, teriam sempre seguidos a "doutrina econômica da escola da ortodoxia monetária" (PELÁEZ, 1971b, p. 81) ao reduzirem a oferta de moeda durante os períodos de contração que sempre teriam agravado as crises.

Apesar de Furtado nunca haver respondido essas críticas, muitos autores se posicionaram sobre o assunto ${ }^{81}$. Uma espécie de conciliação dos dois pontos de vista foi feita por Silber (1973; 1977), ao ressaltar pontos positivos dos dois lados das interpretações. Furtado teria tido o "insight" de perceber as medidas políticas do governo Vargas em relação ao café como importantes para a manutenção da renda, mesmo que, contudo, Furtado não tenha percebido que este financiamento não fora gerado apenas por criação de moeda, e nem tenha dado relevância aos superávites na balança comercial causados em especial pela transferência dos recursos da cafeicultura para a produção de algodão. Por outro lado, baliza o argumento de Peláez, ao dizer que o café não fora somente financiado por impostos, mas teria havido, também, criação de moeda, indicativo de políticas keynesianas avant la lettre, e não teriam sido, portanto, políticas “ortodoxas" como insiste tanto em dizer. Além disso, afirma que Peláez não teria levado em conta a forma como o câmbio desvalorizado teria ajudado a manter a renda no setor exportador (mesmo que o algodoeiro e não o cafeeiro), mas, mesmo que o grosso da renda do cafeicultor tenha sido invertido diretamente ao setor algodoeiro, isso não significava que não teria sobrado nada para a indústria ${ }^{82}$.

\footnotetext{
${ }^{81}$ Um resumo do debate se encontra em Fonseca e Salomão (2017). Aqui destacamos apenas alguns dos trabalhos que entraram na discussão. Dentre aqueles que pendem mais ao lado da tese de Furtado, pode-se identificar Castro (1971), Fishlow (1972) e Oliveira (1981). Entre os que pendem mais para o argumento de Peláez encontram-se Dean (1971), Nicol (1974) e Leff (1982 [1964]). Mesmo assim, cada análise traz uma perspectiva bem particular, sendo mais "cinzentas" as posições de cada um, ao invés de um "preto" e "branco" como Fonseca e Salomão (2017) parecem fazer parecer.

${ }^{82}$ É importante perceber a mediação que Fishlow (1972) faz: "A conclusão final de tudo isto é que a política cafeeira não foi provavelmente tão central para a recuperação inicial da depressão como Furtado declarou, nem tão simples como ele descreveu, mas também não foi tão insignificante como Peláez concluiu."
} 


\subsubsection{O café como atraso}

É importante, aqui, percebermos a importância que o algodão teve na década de 1930. Mais do que discutir se houve, ou não, transferência dos cafeicultores para a indústria (argumento próximo a Furtado), ou para o algodão (argumento próximo a Peláez), ou, ainda, se a renda brasileira obtida fora maior do que na década de 1920, ou menos candente do que em outros países — pois aqui se teria instituído uma política "anticíclica" aos moldes "keynesianos avant la lettre" (Furtado) - , deve-se entender o que representava a cafeicultura para Delfim. Esta atividade, tendo sua importância no Brasil ao longo do século XIX, representava o atraso no século XX, como se fosse uma âncora que não permitiria o Brasil se desenvolver. Mesmo que ela garantisse entrada de riquezas e aumento do PIB per capita, isso não é desenvolvimento para Delfim. Como será exposto no terceiro capítulo dessa dissertação, o desenvolvimento, para Delfim, é mais do que o aumento de renda per capita, é a mudança de estruturas e formas produtivas. O Brasil, ao realizar as defesas do café (mesmo que em resposta a um mecanismo inerentemente estável), garantia não o desenvolvimento brasileiro, mas sim a permanência de uma classe de dirigentes parasitária ${ }^{83}$, que não mais atuava em direção ao desenvolvimento brasileiro. Ou seja, ao se realizar a defesa, o Brasil estagnava-se em suas formas de produções, impedindo-a de avançar, ou garantindo que a mudança fosse mais lenta. Perpetuava-se o atraso. No segundo capítulo dessa dissertação, mostramos como Delfim vinha advogando uma maior atenção para o desenvolvimento da cultura algodoeira, em detrimento de outras. O algodão representava uma diversificação maior nas entradas das divisas ${ }^{84}$, fornecimento para as manufaturas nacionais e, com isso, uma maior urbanização, industrialização e mercantilização da vida. $\mathrm{O}$ avanço. A insistência da cultura cafeeira retardava (e poderia chegar a impedir) a realização desses objetivos.

No livro "O Problema do Café no Brasil", Delfim, ao discutir o mercado de café no século XIX — sem intervenção governamental, portanto —, mostra como naquele

\footnotetext{
${ }^{83}$ Como será mostrado no capítulo seguinte, Delfim questiona as "formas de propriedade altamente onerosas para a coletividade", afirmando: "aquele que vive apenas da renda de seus capitais, não contribuindo pessoalmente de nenhuma forma para a solução do problema mais amplo, que é o do estabelecimento de formas de convivência social mais adequadas à realização do homem, não tem porque exigir o respeito à sua propriedade." E que a "melhor alternativa para os proprietários" não é necessariamente "a melhor alternativa do ponto de vista social" (DELFIM NETTO, s.d., p. 63).

${ }^{84}$ Além disso, caso grande parte das entradas de divisas dependessem da exportação de algodão, estas seriam (indutivamente) menos instáveis do que as do café, pelos motivos que Delfim explicará à frente; mas, pode-se perceber que é uma cultura menos perene, e cuja produção de algodão responde mais rapidamente ao plantio. Assim, a adequação da oferta, com a variação da demanda se faria bem mais rapidamente, permitindo, então, uma entrada de divisas mais estável.
} 
período o café havia sido o avanço para o país. Ele teria garantido riqueza e prosperidade, além da formação de um mercado interno assalariado. Mas, como ele mostra, o café é um produto altamente instável, que - mesmo sem intervenção estatal — garantiria uma entrada de divisas com uma amplitude muito alta, e com um mercado que já se encontrava com uma oferta saturando a demanda no final do século. Essa saturação do mercado não teria existido antes. Por exemplo, quando, durante a guerra do Paraguai, o volume de circulação da moeda praticamente triplicou no Brasil, "sem pressionar, como seria de se esperar, a taxa cambial" (DELFIM NETTO, [1958] 2009, p. 44), porque a ampliação do volume exportado teria permitido a entrada de divisas em número suficiente para a manutenção do câmbio, mesmo com os preços do café entrando em declínio.

Os três ciclos de preço por ele discutidos (1857-1868; 1869-1885; 1886-1906) mostram como os problemas com o café vão se avolumando. No primeiro ciclo, a discrepância entre oferta e procura não é tão grande, e logo os preços se ajustam. No segundo, essa discrepância teria aumentado mais, sendo o ajuste mais delicado. No último, contudo, a safra vem a ser tão grande que passa a ser necessária a intervenção governamental, a fim de impedir que ocorresse uma grande crise no processo. Cabe, aqui, fazer uma distinção; pois, se é verdade que as amplitudes dos ciclos foram aumentando, também é verdade que o último ciclo contou com políticas governamentais que incentivaram ainda mais o plantio, desembocando em um provável desajuste ainda maior entre oferta e procura (do que seria sem as políticas de incentivos ao plantio pelo governo).

Mesmo assim, já nos dois primeiros ciclos, percebe-se que a falta de questionamento baseada na "crença irrestrita no sistema de preços para regular a economia que vigorava naquele período", a qual fora muito deletéria; melhor seria se tivesse havido "dúvidas sobre a eficiência desse mecanismo", pois, assim, "não teriam sido permitidas as flutuações de preços verificadas dentro de cada ciclo (...) e desde cedo teríamos encontrado tentativas de estabilizar em algum ponto a receita de divisas do país" (DELFIM NETTO, [1958] 2009, p. 44).

Essa instabilidade se explica mais do que somente pelo fato de o cafeeiro ser uma planta "perene que apenas produz completamente no seu $4^{\circ}$ ou $5^{\circ}$ ano de vida e, depois disso, continua produzindo economicamente durante (...) 15 ou 20 [anos até] (...) 50 ou 60 anos, em áreas excepcionais" (DELFIM NETTO, [1958] 2009, p. 16). Essa peculiaridade da plantação do café poderia ser explicada por um modelo de teia de aranha comum, cuja estabilidade dependeria apenas da relação entre as elasticidades das curvas de oferta e 
procura. Caso a curva - nesse modelo - de oferta fosse mais inclinada que a curva de demanda, haveria convergência; caso o contrário se sucedesse, haveria divergência ${ }^{85}$. A amplitude do modelo de café proposto por Delfim, não é a de um modelo de "teia de aranha" comum. Em seu modelo a instabilidade é crescente (mesmo considerando as inclinações das curvas de demanda e oferta iguais em módulo), pois é mais complexo do que um simples modelo de defasagem. A oferta de café (ou sua plantação) variaria com o preço atual, com o preço do momento anterior e com a variação do preço de outros produtos que poderiam ser plantados em lugar do café, o chamado custo de oportunidade do café. Já a demanda dependeria do preço naquele período, da renda per capita, do aumento populacional e de uma demanda dos especuladores (os quais procurariam aumentar as compras com a perspectiva de alta do preço, e as diminuir com a perspectiva de baixa), resultando, então, em um modelo muito mais complexo e mais instável do que um simples modelo de teia de aranha.

Por outro lado, somada a esta alta amplitude dos preços do café (inerente ao próprio mercado), o terceiro ciclo contou, ainda, com a política de expansão creditícia e monetária - tomada a cabo pelo governo no início da República -, conhecida por “encilhamento”, que consistiu em uma generosa expansão do crédito e da moeda. Essa política era incentivada pelos plantadores de café, os quais - como Delfim ressalta utilizando-se Taunay - tinham "incutidos" em seus "espíritos", "o absurdo aforismo de que câmbio baixo correspondia, automaticamente, a café alto" (Taunay, 1946, p. $253^{86}$ ), e ficavam "alarmados até com a possibilidade da valorização do mil-réis". A desvalorização do câmbio era uma forma de transferir renda do trabalhador para o cafeicultor, pois o custo de vida dependia muito das importações naquele momento e a mão de obra, para Delfim, era um custo bastante alto para o produtor, porquanto havia uma alta escassez de trabalhadores (a imigração já havia diminuído), pela grande competição por se contratar mão de obra entre os agricultores:

Antes mesmo que o cafezal pudesse produzir, já se encontravam os empresários em situação difícil, pois os custos se elevavam pelo aumento da taxa de juro (diante da escassez de capitais para financiar acréscimos de cultura) e pelo aumento da taxa de salário (diante da escassez da mão de obra), de maneira a eliminar quase todo o lucro

\footnotetext{
${ }^{85} \mathrm{O}$ chamado Modelo de teia de aranha, ou Cobweb, foi muito utilizado, em especial para problemas agrícolas, nos quais há defasagens entre o aumento da demanda e o tempo que a oferta leva para responder (Pashigian, 2017). Tendo recebido esta denominação por Kaldor (1934), o modelo foi aprimorado por Ezekiel (1938).

${ }^{86}$ TAUNAY, A. Pequena História do Café no Brasil (1727-1937). Departamento Nacional do Café - Rio de Janeiro, 1945, p. 253, apud DELFIM NETTO, [1959] 2009, p. 45.
} 
criado passageiramente pela depreciação cambial (DELFIM NETTO, [1958] 2009, p. 49).

Então, o mecanismo de transferência de renda no período do encilhamento funcionava assim: criava-se moeda, levando a um aumento dos preços (inflação), o qual pressionava o câmbio, desvalorizando-o, e, assim, uma parte maior da renda da sociedade era desviada para o setor exportador, que se beneficiava com câmbio mais baixo. Essas novas poupanças, diz Delfim, eram diretamente encaminhadas para novas produções de café, e, nessas expansões, por efeito da já discutida escassez de mão de obra, os salários voltavam a crescer e se retornava à razão da distribuição da renda anterior à desvalorização. "Era, portanto, inútil permitir que o círculo vicioso voltasse a se completar" (DELFIM NETTO, [1958] 2009, p. 50).

Nessa interpretação, Murtinho ${ }^{87}$, então "em um ambiente inteiramente conturbado" (DELFIM NETTO, [1958] 2009, p. 50), ao realizar uma política de contração do crédito, aparece ao lado dos assalariados, indo de encontro aos interesses dos cafeicultores, ao impedir que novos recursos fossem aplicados em mais cafezais à custa de uma diminuição temporária do salário. Após Murtinho, o mercado já dava sinais de se encontrar em uma situação de saturação de café; inclusive, discutia-se desde 1898 a possibilidade de queima do produto $^{88}$. Delfim interpreta que é na década de 1890 que teve origem o problema cafeeiro vivido "no último meio século" no Brasil (DELFIM NETTO, [1958] 2009, p. 32). Pela primeira vez, o aumento da exportação do café não fora suficiente para compensar a queda de preços do produto, fazendo com que, naquele período, o câmbio depreciasse mais rapidamente (dado a inflação causada pelo encilhamento) do que a queda dos preços externos (fazendo, assim, com que os preços internos do café aumentassem), criando condições para a expansão da cultura cafeeira, mesmo com o mercado internacional deprimido. (DELFIM NETTO, [1958] 2009, p. 35).

Uma das explicações dadas por Delfim para a constante desvalorização do câmbio nessa década é o fim da escravidão, a qual "constitui a mola mais importante para a transferência da lavoura cafeeira do Rio de Janeiro para São Paulo" (DELFIM NETTO, [1958] 2009, p. 29). A elite cafeicultora paulista se apoiava sobre o trabalho livre

\footnotetext{
${ }^{87}$ A referência é ao período que Murtinho foi Ministro da Fazenda (1898-1902) no Governo Campos Sales, após o período do encilhamento. Suas medidas mais famosas foram de reduzir os meios de pagamento e de articular o funding loan.

${ }^{88}$ Murtinho é ainda elogiado por querer tirar do mercado os produtores marginais, e por ter tentado "forçar o caminho da ampliação da procura, com o governo promovendo intensa propaganda do produto no exterior, e conseguindo várias reduções tarifárias." (DELFIM NETTO, [1959] 2009, p. 45-46)
} 
(imigrantes e libertos espontâneos), esse é motivo - diz Delfim - por que sete anos após a promulgação da Lei Áurea, a produção cafeicultora de São Paulo passa de dois terços da do Rio de Janeiro, para "seis ou sete" vezes maior. (DELFIM NETTO, [1958] 2009, p. 29). Em especial, junto com a libertação veio a necessidade de monetização do produtor, em decorrência de maiores investimentos na lavoura para construção de casa dos colonos e pagamentos de salário. O chamado "encilhamento" teria tido um papel fundamental na monetização da economia, e na garantia dos cafeicultores em conseguir se manter como contratante ao pagar os salários monetariamente aos trabalhadores.

Interessante que, se, por um lado, quase toda a amplitude dos preços (e, consequentemente, a entrada de divisas) fora permitida "pela crença irrestrita do mecanismo de mercado" nas décadas anteriores a 1890, quando era favorável aos donos de escravos esta crença, por outro lado, ao final do terceiro ciclo de preço do café, quando muitas plantações encontravam-se em perigo, diz-nos Delfim que a ideia de intervenção no mercado ganha força até, finalmente, se concretizar com o chamado "Convênio de Taubaté", em 1906. A expectativa era uma produção, naquela safra, de "volume até então desconhecido" (DELFIM NETTO, [1958] 2009, p. 59). Tão grande que, e.g., a perspectiva de compra de 4 milhões de sacas exigiria 160 mil contos de réis, sendo que o numerário total brasileiro havia sido de 670 mil contos de réis em circulação no período, indicando quanto a compra por meios internos era irrealizável. Por esse motivo, a compra não poderia ser financiada internamente, e os cafeicultores não poderiam, então, serem salvos pela maneira tradicional. Foi assim que a ideia de financiar a compra com crédito externo se impôs, pelo volume que a oferta tomou, e pela manutenção das estruturas ${ }^{89}$, ao contrário da forma como vinha sendo feita a defesa, com o aumento de crédito (encilhamento) e desvalorização. O tamanho daquela safra

Não se resolveria dentro de uma economia de mercado. (...) É possível (...) que o rendimento obtido com o produto fosse insuficiente para cobrir as despesas de custeio, mesmo das culturas mais produtivas, $\mathrm{o}$ que poderia representar a eliminação completa da cafeicultura nacional (DELFIM NETTO, [1958] 2009, p. 57).

A falta de possibilidades de que uma safra daquelas dimensões fosse resolvida por mecanismo de mercado, a não ser causando uma crise profunda no Brasil, se apresentara como a possibilidade perfeita para que os cafeicultores "socializassem suas perdas"-para

\footnotetext{
${ }^{89} \mathrm{~A}$ safra que na previsão era de 16 milhões de sacas e já causara grande alvoroço pela sua magnitude, concretizou-se, na verdade, em 20 milhões.
} 
se utilizar dos termos de Furtado ${ }^{90}$-, ao realizarem a operação de empréstimos externos e proteções do preço do café a partir da compra e armazenagem deste. Então, mais do que ser a favor ou contra o mecanismo de mercado para regular a economia, vemos como, para Delfim, a "crença" do momento funcionou apenas para servir à elite do momento. Em um primeiro ensejo, a "crença irrestrita nos mecanismos de mercado"; já, em uma segunda ocasião, quando a elite necessitou, houve "encilhamento" e regulamentação e compra do café; claras interferências no mercado cafeeiro.

Delfim - reconhecendo que o problema não era resolvível por mecanismos de mercado é crítico à operação, que viria pura e simplesmente "para atender aos interesses de uma classe que sofria os azares da atividade empresária" (DELFIM NETTO, [1958] 2009, p. 64). Não só ele critica a defesa feita com esses propósitos, como também critica o discurso usado para tal. Haveria sido, naquele momento, que teria se difundido plenamente a ideia de que o problema do câmbio, do café e do Brasil eram o mesmo, ou ainda, que compartilhavam de causas iguais. Portanto, teria sido possível unir - no discurso - os problemas dos cafeicultores aos de todos os brasileiros, algo muito conveniente àqueles, impedindo que outra elite surgisse:

Ninguém desejava entender o fato de que a ruína dos fazendeiros simplesmente transferiria suas propriedades para outros empresários, como Calógeras acentuaria mais tarde, mas que o rendimento nacional, passados os momentos iniciais de surpresa causados por esse trauma, continuaria exatamente o mesmo (DELFIM NETTO, [1958] 2009, p. 46).

Assim, para que se resolvessem esses problemas "de superprodução" e a renda se transferisse para os cafeicultores, em meio àquela crise, era necessário manter o câmbio a uma taxa constante, pois, "é evidente que se a valorização tivesse bom êxito, ela pressionaria a taxa cambial para cima" (DELFIM NETTO, [1959] 2009, p. 64). Essa pressão altista no câmbio aconteceria em razão da pressão que a "venda das cambiais, obtidas com o empréstimo externo" para a compra do café aumentariam a oferta de divisas e levariam a uma "elevação dos preços do café" com a mesma quantidade exportada. Então, tudo indicava que a defesa - caso mantido o câmbio flutuante -, ao valorizar o câmbio, destruiria todos os benefícios internos para os cafeicultores. "Para assegurar esses benefícios, seria necessário, consequentemente, estabilizar a taxa cambial" (DELFIM NETTO, [1958] 2009, p. 62); E por isso foi idealizada a "caixa de

\footnotetext{
${ }^{90}$ Termo cunhado por Furtado ([1959] 2007) em seu famoso livro "Formação Econômica do Brasil".
} 
conversão", a qual ampliaria ou encurtaria a quantidade de meios de pagamentos à disposição da coletividade ${ }^{91}$.

Contudo, os desejos dos cafeicultores brasileiros - mesmo que pudessem se impor dentro do Brasil - não poderiam ser impostos ao mercado internacional. Em especial em um mercado dominado por poucas firmas estrangeiras importadoras/torradoras, que funcionariam como "condutora de um oligopólio"92. Houve três defesas "episódicas" durante o século XX (1906-1918; 1917-1920; 1921-1924³). Destas, a segunda valorização somente teria funcionado por fatores outros que a compra governamental. $\mathrm{O}$ mais importante fora o final da primeira guerra mundial e a geada de 1918. Já, a primeira e a última contaram com bancos e casa torradoras internacionais, e esse ponto foi fundamental, na interpretação de Delfim, para se ter conseguido o aumento de preço com a defesa ${ }^{94}$. A primeira começara em 1906, contudo, já em junho de 1907 a compra fora interrompida (com São Paulo já tendo adquirido 8 milhões de sacas de café (DELFIM NETTO, [1958] 2009, p. 67), e mesmo assim a queda dos preços não pareceu ter reagido à intervenção. No segundo semestre de 1907, atingiram seu menor valor até então (de 6,26 cents por Libra-Peso), continuando a cair no primeiro semestre de 1908 (6,22 cents por libra peso). Só é observada a reversão dessa tendência cadente, após "quase todos os grandes capitais interessados no negócio do café" estarem envolvidos de "maneira importante na operação, pois os predispunha a encará-la como um negócio seu (...) numa larga medida, a primeira valorização foi um corner executado por capitais particulares" (DELFIM NETTO, [1958] 2009, p. 83). A segunda operação “esporádica” de defesa dos preços do café, iniciada em 1917, também não fora - para Delfim - a grande responsável pelo aumento dos preços, mas sim a forte geada ocorrida em 1918, a qual levou a uma corrida pelos especuladores para conseguir café, pois esperavam ao menos dois anos de safra pequena em razão do incidente. Então, por causa do fenômeno climático - e não

\footnotetext{
${ }^{91}$ A caixa de conversão não era uma ideia incomum, sendo um artifício usado em muitos lugares e em momentos históricos diferentes. Para mais informações, conferir Hadba (1994).

92 "O mercado cafeeiro era então, como é hoje, dominado pelo comportamento de algumas grandes empresas torradoras, que funcionam como condutoras de um oligopólio" (DELFIM NETTO, [1959] 2009, p. 42)

${ }^{93}$ Essas são as datas utilizadas por Delfim.

${ }^{94}$ Por exemplo, a operação em 1923-24 "pelo contrato da valorização em curso, o governo somente poderia operar pelas mão da Brazilian Warrant Co." (DELFIM NETTO [1959] 2009, p. 105). E "levantou-se um empréstimo de 9 milhões de libras esterlinas. Com esse empréstimo )da mesma maneira que ocorrera na primeira operação), nomeou-se uma comissão de banqueiros (ROthschild, Schroeder e um representante da Brazilian Warrant Co.) e um elemento escolhido pelo governo brasileiro para tratar da liquidação paulatina dos estoques" (DELFIM NETTO, [1959] 2009, p. 97)
} 
pela intervenção -, São Paulo realizou grande lucro nos anos seguintes. Contudo, como afirma Delfim, essa compra, por ter sido financiada pela emissão de papel-moeda (sem lastro, significando criação de moeda para comprar produtos dos cafeicultores), foi paga pelo resto "da coletividade" pela forma de inflação. Do ponto de vista contábil, o grande lucro ajudou no discurso de que a defesa do café significava a defesa do Brasil. Ainda pior, restrições ao plantio (impostas em 1902) desapareceram após esse episódio, o que significaria ainda mais produto ofertado a uma demanda que já não o conseguiria absorver.

Dessa forma, quando começou a crise pós-guerra nos Estados Unidos, a qual fora "curta e severa" (DELFIM NETTO, [1958] 2009, p. 92), a valorização (pelos louros outrora recebidos, pois - como visto - representou lucro do ponto de vista contábil), fora prontamente sugerida como forma de resolver a possível superprodução já em 1923. Contudo, esta se realizara em diferentes moldes, porque, ao se resolver estocar a produção no interior do país, e não mais em mãos de importadoras estrangeiras ou nos portos, como havia sido feito nas duas primeiras, tirou do controle das mão deles ${ }^{95}$, pois:

Mostrava aos importadores [de café] que eles não passariam mais ao controle do mercado e que por muito tempo poderíamos impor nossos preços. A única saída para tal situação seria o estímulo da produção de outros países. Sabe-se, aliás, que muitos investimentos americanos foram realizados na Colômbia nessa época (DELFIM NETTO, [1958] 2009, p. 100).

Ou seja, se nas outras defesas - principalmente na primeira - a operação fora bemsucedida, pois era coadunada com bancos financeiros internacionais dos principais países, esta, ao bater de frente com os interesses dos importadores-especuladores, os teria levado a procurar alternativas ao monopólio brasileiro ${ }^{96}$. Vê-se, dessa forma, como a elite cafeeira, ao tentar se manter, foi apenas postergando um problema maior ${ }^{97}$. A própria elite mantinha, durante a década de 1920, domínio sobre o governo de São Paulo:

\footnotetext{
${ }^{95}$ Em dezembro de 1924 cria-se o "Instituto de Defesa Permanente do Café".

${ }^{96}$ Delfim afirma, no capítulo seguinte, que: "durante a campanha Hoover, em 1925, tornou-se um lugarcomum afirmar-se que os Estados Unidos deveriam interessar outros países na produção do café e que deveriam encorajá-los, adquirindo os seus produtos." (Delfim Netto, [1959] 2009, p. 109), e, também, "O mecanismo utilizados para a defesa, precisamente por sua eficiência, gerou grande irritação nos importadores, que compreenderam que agora lhes seria impossível (...) reconstituir os seus estoques e passar novamente ao comando do mercado." (DELFIM NETTO, [1959] 2009, p. 99); e ainda: "A única saída [para os importadores] para tal situação seria o estímulo da produção de outros países. Sabe-se, aliás, que muitos investimentos americanos foram realizados na Colômbia nessa época." (DELFIM NETTO, [1959] 2009, p. 100)

${ }^{97}$ Essa postergação do problema com a defesa parece com a opinião de Furtado ([1959] 2007, p. 259) quando este diz: "A manutenção dos preços a baixos níveis era condição indispensável para que os
} 
(...) é preciso considerar-se que na década de 1920, mesmo o governo do Estado de São Paulo era, em boa parte, dominado pelos interesses da classe agrícola, de maneira que, de fato, o instituto era controlado pelos próprios cafeicultores. Nessas circunstâncias, era difícil esperar que o instituto cortasse fundo quando isso fosse necessário (DELFIM NETTO, [1958] 2009, p. 109)

Toda a defesa, ao longo do século $\mathrm{XX}$, fortaleceu a concorrência de outros países produtores. Contudo, a defesa permanente fora a que mais instigou os importadores a procurarem alternativas e a se instalarem em outros países. Em especial na Colômbia ${ }^{98}$. Somado a esse aumento da concorrência, e perda de compradores, a safra 1927-1928, que fora muito grande, ainda foi acompanhada pela perspectiva de uma safra ainda maior em 1929. Em companhia deste cenário somou-se a crise na Bolsa de Nova Iorque: o preço do café foi de 22,4 cents por libra-peso, em setembro de 1929, para 12 cents por librapeso no segundo semestre de 1930. "O sistema de defesa dos preços do café, cuidadosamente armado pelo Estado de São Paulo, ruiu sob a pressão de várias forças". (DELFIM NETTO, [1958] 2009, p. 117). Washington Luís - para continuar com o mando do governo e poder passá-lo a seu sucessor (Júlio Prestes) - ainda tentou de qualquer forma vender as sacas de café em posse do Instituto ao preço que fosse, mesmo que isso significasse preços muito baixos, o que garantiria pelo menos entradas de divisas. Delfim elogia essa política - pois era da opinião que o Brasil sempre deveria ter deixado o preço baixo do café -, mas ela não teria dado certo em razão do momento histórico ser de uma crise de enormes magnitudes.

Em resposta à crise - coincidentemente com um momento de forte crise do café - "em outubro de 1930, um governo de força assumiu a direção do país e, em janeiro do ano seguinte, o seu interventor em São Paulo reorganizou o Instituto do Café” (DELFIM NETTO, [1958] 2009, p. 122). Esse governo "de força" assumiu a política cafeeira nacional, tirando-a do controle de São Paulo. Em 1933, destruíram-se 13,9 milhões de sacas, o equivalente à exportação de um ano, dando claros indícios de que aquela “indústria sofria de um excesso de capacidade, que levaria ainda algum tempo para ser corrigido" (DELFIM NETTO, [1959] 2009, p. 125). A atuação desse governo em relação

produtores brasileiros retivessem sua situação de semimonopólio. Ao se prevalecerem dessa situação semimonopolística para defender os preços, estavam eles destruindo as bases em que se assentar o seu privilégio. Dessa forma, por mais bem concebida que tivesse sido a política de defesa dos preços do café, a longo prazo ela surtiria certos efeitos negativos. Esses efeitos teriam sido certamente menores se a referida política houvesse obedecido a princípios mais amplos. Não resta dúvida, porém, de que, na forma como foi seguida, ela precipitou e aprofundou a crise da economia cafeeira no Brasil” (FURTADO, [1959] 2007, p. 259)

${ }^{98}$ Com apoio do governo Estadunidense o qual combatia, à época, o oligopólio do café. 
às políticas cafeeiras é muito elogiada por Delfim — inclusive a operação da queima/destruição (cotas de sacrifício) do café, pois "queimar uma saca de café é, do ponto de vista social, menos importante do que despedir um chefe de família e forçá-lo a roubar ou a prostituir sua esposa para alimentar seus filhos" (DELFIM NETTO, [1959] 2009, p. 127). Assim, o novo governo taxou a exportação de café como forma de se tentar segurar os custos das próprias políticas cafeeiras e (além de pagar um preço para o cafeicultor da quota de sacrifício mais abaixo do que o custo), também, forçou o mercado internacional (a partir de 1937) com preços menores como forma de abocanhar parte do mercado atendido por seus concorrentes (aumentar o market share).

O resultado da política do governo foi que, após a Segunda Grande Guerra, a produção brasileira e os estoques diminuíram muito ${ }^{99}$, gerando uma corrida por parte dos importadores para fazerem estoques. Somado à política do governo brasileiro, a Colômbia, "comprometida na compra de sua produção" (DELFIM NETTO, [1959] 2009, p. 130), fez com que o diferencial de preços entre o café colombiano e o brasileiro aumentasse, aumentando ainda mais a exportação brasileira. Analisando o período, teria sido somente a partir do momento em que o controle das políticas do café saiu dos interesses dos próprios cafeicultores, que este teria se subordinado aos interesses do Brasil (pois um "governo de força" fizera frente aos interesses paulistas), ao garantir mercado, eliminar produtores menos produtivos e liberar recursos brasileiros para outras atividades. Com a crise e a guerra, que perduraram longos anos (1930-1945) sob o governo Vargas, as plantações de café no Brasil diminuíram e tinham se ajustado à demanda. Ao longo da década de 1940, os estoques foram liquidados, e esse seria o principal motivo da alta de preços da década seguinte ${ }^{100}$. Em 1951, os EUA definem um teto ao preço do café, tentando controlar a alta. Esta alta de preços pode ter sido causada por muitos fatores; contudo, é importante lembrar que o "mercado cafeeiro é inerentemente instável e que o livre funcionamento dos mecanismos de mercado deverá apresentar um preço que flutua amplamente" (DELFIM NETTO, [1959] 2009, p. 183). Em toda a história que Delfim descreve da economia cafeeira, o único momento em que o autor faz o leitor entender que foram acertadas as políticas foi durante o "governo de força" de 1930. As políticas de

\footnotetext{
${ }^{99}$ A razão para isso, diz Delfim, é porque se queimou muito café. "A destruição, iniciada em junho de 1931 e terminada em julho de 1944, eliminou nada menos do que 78,2 milhões de sacas de café, ou seja, uma quantidade equivalente a três vezes o consumo mundial num ano." (DELFIM NETTO, [1959] 2009, p. 129).

${ }^{100}$ Somado à Guerra da Coreia, iniciada em 1950.
} 
Getúlio conseguiram controlar a oferta e expansão da cafeicultura - para que essa se reajustasse à demanda -, o que significa dizer que conseguiu controlar os cafeicultores (e não estes controlando a política econômica, como Delfim mostra que era como havia sido anteriormente) sem, contudo, criar desemprego ou uma recessão generalizada. Contudo, com o fim desse governo, a situação volta a ser periclitante, com a década de 1950 acumulando crise após crise do café, com compras (por meios inflacionários) do produto e sucessivas desvalorizações, mantendo os ganhos dos cafeicultores ${ }^{101}$. Mesmo com o governo tendo que intervir no mercado, pois o Brasil não conseguia escoar todo seu café, o preço do produto internamente crescera bastante, passando de $110,11 \mathrm{Cr} \$ / 10 \mathrm{Kg} \mathrm{em}$ 1949, para 229,44 Cr\$/10Kg em 1953, e para 439,25 Cr\$/10Kg em 1956. O governo da época parecia ainda não solucionar, e uma política que pouco fazia sentido fora posta em prática:

Para dar maior resistência ao cafeicultor, garantiu o governo o financiamento do produto a $80 \%$ dos níveis de preço-mínimo que vigoraram para a safra anterior (1956-57). Sem abandonar a defesa, necessária ao programa de "metas", instituído pelo presidente da República eleito em 1955, o governo federal transferiu o seu ônus para as costas do empresário agrícola. É evidente, entretanto, que a existência de um excesso de capacidade de produção torna completamente instável esse processo de defesa e é certo que o governo federal terá de comprar café em um futuro próximo (DELFIM NETTO, [1959] 2009, p. 134)

Se se comparar a atuação do governo “de força”, na própria expressão de Delfim, de 1930 com a atuação daquele eleito em 1955, pode-se perceber a principal diferença: o primeiro fez uma política de controle, não só dos cafeicultores (pois lhes direcionava a quantidade a ser invertida em café), como também dos trabalhadores, ao garantir-lhes emprego, mesmo que a uma remuneração nominalmente mais baixa ${ }^{102}$. Já o novo governo se apresentaria como continuador da defesa, sem conseguir controlar as quantidades invertidas no café, e tendo que intervir de qualquer maneira. A diferença é que não se estaria passando por uma crise como nos anos 1930, então, essa intervenção estaria apenas

\footnotetext{
101 “Após algumas oscilações, o preço do café, em novembro, retomou a sua marcha ascendente, acelerada, já em 1954, pelos efeitos da grande geada. Nesse mesmo ano, o Brasil pretendeu desastrosamente defender o preço mínimo de 87 cents/libra-peso, o que reduziu de maneira importante o volume dos negócios, principalmente porque criou-se um ágio do Santos 4 sobre o Manizales. Para contornar-se a crise, concedeuse uma desvalorização para o dólar-café da ordem de $30 \%$, mas os operadores não retomarem o seu ritmo de negócios, diante das perspectivas de novas baixas, causadas pelo maior volume da safra 1954-55" (DELFIM NETTO, [1959] 2009, p. 134).

102 "É evidente que o pagamento em dinheiro se refere a apenas uma parte da remuneração real do colono, pois os contratos de trabalho incluem, em geral, o fornecimento de terra para a plantação de alimentos, para pequenas criações, o fornecimento de lenha e de certa quantidade de café para o consumo." (DELFIM NETTO, [1959] 2009, p. 195)
} 
funcionando para garantir a posição dos cafeicultores, e não para salvar a economia, com a única conclusão de que "todo o sistema de defesa caminha para uma liquidação violenta e fatal" (DELFIM NETTO, [1959] 2009, p. 134). O problema causado por uma séria crise do setor cafeeiro é que ela afetaria todo o resto da economia, porque

Uma parcela importante da produção industrial do país (principalmente da indústria de tecidos) é absorvida pelos trabalhadores agrícolas que, quando veem diminuída a parte do seu salário monetário, não têm meios de pagamentos para continuar a realizar aquelas compras, a não ser à custa da venda de sua produção suplementar. Acontece que essa produção suplementar exige um "tempo", dentro do qual o poder de compra dos trabalhadores agrícolas diminui efetivamente, e deve reduzir-se à procura dos produtos industriais. (...) É conhecido, por outro lado, que mesmo uma redução pequena das vendas aos consumidores pode gerar um movimento cumulativo capaz de paralisar amplos setores da economia (DELFIM NETTO, [1959] 2009, p. 196)

Em resumo, o café se apresentaria como um produto essencial para a economia brasileira, e não se poderia se livrar dele de uma vez só sem incorrer em uma crise de grandes proporções. Por outro lado, o café prenderia recursos que deveriam ser aplicados em outros lugares da economia, em especial na produção de alimentos, para que se pudesse dar continuidade no desenvolvimento econômico. A defesa impediria que pudessem ser utilizadas as melhores tecnologias já existentes no campo e liberar recursos para a indústria.

A chave do processo de desenvolvimento econômico reside principalmente numa melhoria da produtividade do setor agrícola, o que, a um só tempo, libera mão de obra e eleva o nível de rendimento dos que ficaram no campo. (...) Se considerarmos, finalmente, que esses excedentes são sustentados por um subsídio pago por toda a coletividade sob a forma de inflação, chegamos à conclusão paradoxal de que a sociedade paga pra não crescer!"103

Delfim insiste no ponto de que é necessário aumentar a produtividade do setor agrícola (em especial do produtor de alimentos) para que seja liberada mão de obra para outros setores:

É possível, num estágio posterior do desenvolvimento econômico, depender-se, em escala maior, da importação de produtos agrícolas, mas pensamos que é praticamente impossível, num país como o nosso, a geração daquele processo não se apoiar nos ganhos de produtividade da agricultura, pois, por maior que fosse a produtividade do setor industrial, ele não poderá contar com a mão de obra necessária, se

103 Perto desta passagem, Delfim traz, para auxiliar seu argumento, a "Lei de Engel", que afirma que, à medida que a renda aumenta, a parte desta dispensada a alimentos cresce em menor proporção. Um dos corolários dessa afirmação é que, à medida que a renda do Brasil crescesse, seria necessária menor produção de alimentos em proporção aos outros bens produzidos. (Delfim Netto, [1959] 2009, pp. 211-212). 
essa mão de obra não for liberada das atividades primárias. (...) É, portanto, da própria essência do desenvolvimento, que ele se realize à custa de uma transferência da mão de obra da agricultura para as outras atividades, possibilitada pelos ganhos de produtividade no setor agrícola. O caminho pelo qual se realiza essa transferência é precisamente a baixa do rendimento monetário dos produtos agrícolas. A agricultura, mais do que um negócio, é um meio de vida e é preciso, às vezes, esperar uma geração para que a transferência se efetive. (...) Chegamos à conclusão de que o próprio processo de desenvolvimento econômico se apoia em dois pontos: a) um aumento da produtividade agrícola, e b) uma transferência da mão de obra da agricultura para os demais setores da economia (DELFIM NETTO, [1959] 2009, p. 210-211).

É importante notar que a indústria brasileira, nessa perspectiva, poderia ser muito produtiva, e mesmo assim sofreria com problemas de custos de mão de obra, que não as permitiria competir. E, o maior desses custos, seria a mão de obra que continuaria alocada plantando café. A compra de café seria deletéria, pois impediria o incentivo ao aumento de produtividade, demandando mais mão de obra. Impediria a transferência de recursos para outras atividades (como subsistência), encarecendo a mão de obra. Limitaria o aumento de receitas, pois no longo prazo entram menos do que teria entrado em caso contrário. Restringiria o desenvolvimento de alternativas de exportação. Em suma, a compra de café encareceria a indústria pelo custo do trabalho e pelo custo de importação, ao encarecer a compra de insumos (o que também encarece a mão de obra) necessários à indústria (equipamentos, combustíveis, máquinas etc.).

\subsubsection{O acordo mundial do café}

No momento em que Delfim escreve, vêm sendo discutidas tentativas de acordos internacionais por parte dos países produtores de café. A situação à época era esta:

Em 1957, chegou-se a um acordo parcial entre os principais produtores latino-americanos e assinou-se um documento conhecido por Convênio do México, o qual simplesmente fazia referência a quantidades a serem exportadas. Para a safra presente (1958/59) continua em vigor um acordo do mesmo gênero, pelo qual o Brasil se comprometeu a retirar do mercado cerca de $85 \%$ dos excedentes mundiais" (DELFIM NETTO, [1959] 2009, p. 253)

Delfim retoma o ponto de que o melhor para a estabilidade do mercado de café seria um acordo internacional entre os países produtores. Contudo, isso não significa que ela seria melhor para cada país em particular, em especial para o Brasil. Nenhum dos três tipos de 
acordo - estoques reguladores, acordo multilateral de compra e venda e acordo de quotas - interessaria ao Brasil.

Para se entender melhor os conflitos de interesse que havia no acordo - entre os interesses que Delfim entende que cabem ao Brasil (de manter a sua receita de divisas) e os que cabem a outros países - faz-se importante trazer a esta discussão o livro intitulado "El problema del Café", financiado pelo "Banco Internacional de Reconstrução e Fomento" e pelo "Banco Interamericano de desenvolvimento" (AVRAMOVIC, 1958). Este livro, aparentemente escrito entre 1957 e 1958, veio com um propósito - além de um título muito parecido com o do Delfim. Contudo, este estudo evidencia que o problema do café é o fato de haver muito excedente e o fato de que o Brasil detém uma grande parcela de culpa por eles.

Se han recibido informes de que en el Brasil las condiciones del tempo durante la temporada de floración (julio y agosto de 1957) fueron excelentes. A menos que hubiera escasez o exceso de lluvias, es probable que la producción mundial exportable en 1958-59 sea $15 \%$ mayor que la de 1957-58, mientras que el consumo no es posible que aumente más de 3 a 4\%. (...) La mayor parte del excedente tendrá lugar en Brasil (AVRAMOVIC, 1958, p. 23)

O estudo parece muito preocupado com os prognósticos de excedentes de café que se iriam criar para os próximos anos. Poderia significar uma queda muito grande nos preços, o que poderia levar a uma bancarrota de muitos países da América Latina. Assim, faz sentido que bancos que emprestavam dinheiro para muitos desses países se preocupem com a solvência deles.

El no aplicar medidas restrictivas interiores ni concertar una acción internacional puede resultar en un derrumbe, aproximadamente en el año de 1965, aunque el resultado más probable es una disminución regulada y paulatina de la baja del precio hacia un nivel más bajo. Este último curso se propone en el supuesto de que se tomen oportunamente las medidas necesarias para restringir el aumento de la producción y continúen en vigor los convenios sobre ventas (Avramovic, 1958, p. xiixiii).

Apesar, então, de Avramovic defender a necessidade de convênios sobre as vendas do café, Delfim é claramente contrário:

Observemos que nossas conclusões sugerem que uma política de entendimento internacional seria a única maneira de reduzir-se a instabilidade do mercado, mas não sugerem que ela seria a melhor política para cada um dos países e, em particular, para o Brasil (DELFIM NETTO, [1959] 2009, p. 253).

E: 
Não existe nenhum tipo de acordo internacional capaz de garantir a estabilidade do mercado. Mais do que isso: os acordos de preço não garantem a estabilidade da receita de divisas. Existem tipos de acordo que, no caso do café, poderão, inclusive, aumentar a instabilidade da receita de divisas (DELFIM NETTO, [1959] 2009, p. 275).

Assim, verdadeiramente, há uma divergência na compreensão do problema por parte dos dois autores.

La rápida expansión que se espera en lo futuro se debe principalmente a los progresos de Brasil, pues informan que allá se han hecho plantíos después de 1950 en una escale mucho mayor que los años anteriores (...) (Avramovic, 1958, p. 09).

Para Delfim, o ônus do mercado do café não deve ser o encargo do Brasil. O país deve forçar os preços para baixo, caso seja necessário, para ganhar mercado:

A principal vantagem do "robusta" é na produção de café solúvel e as conclusões anteriores mostram que é justamente a produção desses cafés a que será mais prejudicada, na medida em que diminuir o nível de preços de importação. Esse fato reforça, portanto, a indicação de que uma redução dos preços de nossos cafés poderia beneficiar-nos, em detrimento dos africanos (DELFIM NETTO, [1959] 2009, p. 166).

Para não deixar dúvida de que a posição de Delfim era contrária àquela que o Brasil junto às forças alheias internacionais - estava sendo conduzido a tomar, afirma:

Qual a posição do Brasil dentro de um acordo internacional? A experiência tem mostrado que, sendo o Brasil o maior produtor, ele tem que arcar com os maiores custos do acordo e, paradoxalmente, assistimos a ganhos de posição dos concorrentes que permanecem fora do acordo. O Brasil, portanto, é que tem pago mais e recebido menos em todos os entendimentos internacionais (DELFIM NETTO, [1959] 2009, p. 271).

\subsubsection{O Trigo}

Um ano após Delfim defender a sua tese de livre docência sobre o café, publica, conjuntamente com Luiz Mendonça de Freita, um livro sobre o trigo no Brasil (DELFIM NETTO; DE FREITAS, 1960). O livro foi patrocinado pelo Instituto de Economia “Gastão Vidigal"104, da Associação Comercial de São Paulo. Neste livro, faz uma análise bastante pormenorizada sobre a economia tritícola. Há considerações sobre o acordo internacional do trigo, sobre a distribuição geográfica do cultivo pelo Brasil, a demanda no país, a oferta, os transportes e armazenamentos, uma descrição histórica e analítica

\footnotetext{
${ }^{104}$ Este mesmo personagem será presidente, alguns anos depois, da Associação Nacional de Programação Econômica e Social (Anpes).
} 
sobre as políticas do governo para o aumento da produção e, finalmente, as recomendações dos autores sobre como deveria ser uma política do governo para o trigo. Cabe destacar que, para Delfim, o trigo é visto quase como bem supérfluo, pois ele poderia facilmente ser substituído por outros alimentos sem prejuízos nutricionais ${ }^{105}$. Somado ao fato de o trigo ser importado a uma taxa de câmbio muito valorizada, faltalhe argumentos para associar o bem-estar do Brasil com o "bem-estar" da produção de trigo brasileira. Ademais, todos os incentivos criados para estímulo desta produção acabaram por gerar fraudes, levando àquilo que os autores classificam como produção de "trigo-papel"106.

As propostas indicadas seriam excluir o trigo da taxa de importação especial ${ }^{107}$, deixando que o preço do trigo aumente sozinho pelas forças da oferta e demanda, sem interferência. Esse aumento do preço traria duplo benefício: o incentivo a aumentos de produtividades, sem desperdício de recursos por meios de incentivos governamentais (agravados pelas fraudes), e a substituição deste alimento por outros, levando a uma diminuição da demanda por um produto não essencial e muito gravoso na pauta de exportação ${ }^{108}$.

Em terceiro lugar, haveria uma importante consequência para os moinhos. Provavelmente, a grande maioria das pequenas unidades seria eliminada, seja pela integração ou simples extinção. Os ganhos de escala das grandes unidades, possibilitando baixos custos de exploração, tornariam comercialmente inviáveis os pequenos moinhos (DELFIM NETTO; DE FREITAS, 1960, p. 169)

Um ponto interessante é que, neste livro, como no livro sobre o café, esses produtos são encarados da perspectiva do balanço de pagamentos, a qual, em ambos os casos, seria agravada por eles. O café, garantindo a posição de produtores atrasados, e o trigo,

\footnotetext{
105 Ainda, naquele tempo, não existia uma campanha tão grande contra o glúten. Nos dias de hoje, esse argumento seria muito bem aceito.

106 "Esta modalidade de preços fora estabelecida para desencorajar as fraudes do "trigo papel" e ao mesmo tempo criar um incentivo para a absorção do trigo nacional. Ela não só se revelou ineficaz para erradicar as fraudes, como deu origem a um novo tipo altamente lucrativo. Como a remuneração do triticultor não estava mais associada diretamente ao preço pago pelos moinhos, surgiu a possibilidade de ganhar as bonificações asseguradas ao trigo nacional sobre cereal inexistente. Para isso bastaria que se extraísse uma nota de compra em nome de um pseudo produtor" (DELFIM NETTO; DE FREITAS 1960, p. 103-104)

${ }^{107} \mathrm{O}$ trigo era importado por uma taxa cambial bastante valorizada, como forma de subsídio ao consumo do trigo, barateando-o.

${ }^{108}$ Em primeiro lugar, o preço do pão, da farinha ou das massas preparadas com o trigo representa uma parcela pequena do orçamento doméstico. Um aumento no preço do pão, por exemplo, não determinaria uma elevação correspondente no total dos gastos de uma família, porque haveria uma tendência a substituir em parte o consumo de trigo por outros alimentos. (Delfim Netto, 1960, p. 169-170).
} 
garantido por uma política demagoga "feita para garantir votos" e agradar os assalariados, e penalizar, assim, todo o desenvolvimento brasileiro.

\subsection{Diferentes perspectivas em 1959: Delfim e Furtado}

Faz-se aqui, um necessário cotejamento com uma interpretação de Furtado que dialoga com esta aqui exposta. Em especial pois, seu livro Formação Econômica do Brasil, fora lançado no mesmo ano que o Problema do Café no Brasil, e apresenta uma explicação que dialoga - mesmo que implicitamente - com a de Delfim. Para Furtado, dois mecanismos econômicos funcionavam de maneira fundamental: em primeiro lugar, a taxa de câmbio corrigia as diminuições de entrada de divisas em períodos de recessões no preço do café, mantendo assim o lucro do cafeicultor ${ }^{109}$. Neste ponto, parece estar em harmonia com Delfim: o câmbio atuava de maneira a realocar os incentivos dos produtores brasileiros por meio de mudanças nas relações dos preços. Delfim aqui parece próximo ao argumento de Gudin (1934), o qual afirma que somente seria bom para os exportadores (de café) a taxa de câmbio “cadente”, pois eles conseguiriam um lucro maior com a venda do café, mesmo que lentamente o custo de produção, ao aumentar com a desvalorização, retornasse a taxa de lucro deles ao ponto e partida original. Em um breve momento, haveria, com a alta do câmbio, um delay no ajuste dos custos que permitiria uma redistribuição da renda em sentido aos exportadores. Essa desvalorização somente levaria a um aumento do custo de vida e a alta "inevitável e justa do salário" (GUDIN, 1934, p. 20). Contudo, o segundo ponto é que o lucro, para Furtado, expandia-se, pois havia uma abundância muito grande de mão-de-obra a qual residia no setor de subsistência, e, portanto, os salários não se transformavam em custos para o produtor, pois a mão de obra nunca escasseava a este ponto. Aumentando-a, ainda mais, com o maciço ingresso de migrantes europeus.

Furtado parece descrever um modelo muito similar ao de dois setores de Lewis (1954). Este modelo distingue o setor de subsistência do industrial numa economia dualista, por

\footnotetext{
109 “O processo de correção do desequilíbrio externo significava, em última instância, uma transferência de renda daqueles que pagavam as importações para aqueles que vendiam as exportações. Como as importações eram pagas pela coletividade em seu conjunto, os empresários exportadores estavam na realidade logrando socializar as perdas que os mecanismos econômicos tendiam a concentrar em seus lucros." (FURTADO, [1959] 2007, pp. 237-238). E, ainda: "Por outro lado, a cobertura dos déficits com emissões de papel-moeda criava uma pressão inflacionária cujos efeitos imediatos se sentiam mais fortemente nas zonas urbanas. Dessa forma, a depressão externa (redução dos preços das exportações) transformava-se internamente em um processo inflacionário. No último decênio do século, desequilíbrios internos desse tipo foram agravados pela política monetária que seguiu o governo provisório instalado após a proclamação do regime republicano." (FURTADO, [1959] 2007, p. 245).
} 
diferenças acentuadas na forma de produção entre eles (capitalistas e pré-capitalistas) e pelos fluxos migratórios entre ambos. O setor de subsistência possuiria excedentes de mão-de-obra que se deslocariam gradualmente para o setor capitalista (moderno). O grau de absorção dessa mão-de-obra dependeria da taxa de acumulação de capital na indústria e, portanto, dos seus níveis de lucro, os quais seriam por hipótese reinvestidos. Contudo, o que aconteceria, é que os ganhos de produtividade do setor capitalista/moderno seriam todos capturados pelos empresários, e o salário dos trabalhadores iriam se manter constantes (em níveis pouco ou quase nada acima do que seria esperado por eles ganhar no setor de subsistência) ${ }^{110}$. Levando, assim, a um incentivo para se aumentar a produção sem que houvesse pressão para elevação de salários. Para Delfim, como explicado acima, houve tendência a aumento nos salários, pois a mão-de-obra era não só escassa, como cara. Garantindo um equilíbrio entre lucro e salário. Furtado, no Formação Econômica do Brasil, partilha de muitos pontos em comum desta conclusão de Delfim:

A forma como a agricultura se adapta a essa economia de mercado duplo é em parte responsável pela instabilidade crônica da economia brasileira. Ao manifestar-se uma alta nos preços de exportação, os fatores tendem a desviar-se do setor interno para o externo. Assim, ao mesmo tempo que a renda dos consumidores está crescendo, a oferta de produtos agrícolas dentro do país tende a contrair-se por efeito daquele deslocamento de fatores. Como as inversões ligadas ao setor externo exigem, no caso do café, um período de três a cinco anos para madurar, aquela transferência de fatores poderá continuar por algum tempo sem que tenha qualquer efeito sobre a oferta externa. Enquanto se mantiver elevado relativamente o nível dos preços de exportação, haverá tendência à transferência de fatores para o setor externo. Ao madurarem as inversões nesse setor, cria-se muitas vezes uma situação de superprodução. A essa altura os preços do mercado interno possivelmente já terão subido suficientemente para nivelar-se aos de exportação (FURTADO,[1959] 2007, p. 321, grifos meus).

Esse é um ponto de Delfim. O café roubaria recursos da economia, encarecendo a produção de outros produtos, inclusive ao transferir trabalhadores para o setor cafeeiro,

\footnotetext{
${ }^{110}$ Algo que parece ter sido motivo de discussão acerca deste modelo é o fato de que uma das premissas era que a produtividade do setor de subsistência não aumentava. O que suscitou alguns questionamentos, pois, com o êxodo de mão de obra do setor produtor de alimentos para o setor produtor de outros bens, o setor de alimentos precisaria com menos mão de obra, alimentar mais pessoas; em outras palavras, precisarse-ia aumentar a produtividade daquele setor. Para uma tentativa de resposta a esse problema, temos que: "Outro ponto importante de ser levantado diz respeito a um mal entendido comum em muitas análises do modelo Lewis; este é a crença de que o setor não-capitalista seria equivalente ao setor rural ou ao setor não industrial1. Este mal-entendido é conseqüência da popularidade de algumas re-leituras do modelo original que usavam o arcabouço dual para explicar fenômenos relacionados a estes dois tipos de divisão, como os modelos propostos em Ranis e Fei (1961), Todaro (1969) e Harris e Todado (1970). No entanto, é importante notar que Lewis enfatiza que o excesso de mão-de-obra poderia ser encontrado também nas cidades na forma de sub-emprego urbano e me parece plausível pensar que este poderia estar presente também no setor industrial" (INUI, 2006)
} 
encareceria o salário dos trabalhadores das indústrias. (Este último ponto não faz parte da argumentação de Furtado, cabendo apenas a de Delfim). Ressalta-se como a transferência de recursos para o "setor exportador", para Furtado, diminui a oferta de "produtos agrícolas" para o mercado interno (provavelmente com fins de subsistência), encarecendo o preço dos produtos destinados ao mercado interno. O maior problema desse processo, para Delfim, é que boa parte destes produtos de exportação que sugavam os recursos internos era o café, o qual já contava com superprodução há algum tempo, e, caso não fossem as políticas internas, não seria necessário a transferência de nenhum recurso para o setor de exportação com o aumento de preço, pois o mercado já não conseguia absorver a quantidade de café que era produzida. Este parece ser um ponto fundamental de divergência: para Delfim o café não só roubava recursos dos setores voltados à produção interna, como também impedia o desenvolvimento de alternativas à exportação, que aumentariam a entrada de divisas (portanto, diminuindo o custo de todos);

Ao caírem estes, tem início um processo inverso de transferência de fatores, aumentando a produção para o mercado interno na etapa em que se comprime a renda dos consumidores. Existe, assim, no setor primário da economia brasileira um mecanismo de ampliação dos desequilíbrios provenientes do exterior. Essa observação põe mais uma vez em evidência as enormes dificuldades com que depara uma economia como a brasileira para lograr um mínimo de estabilidade no seu nível geral de preços (FURTADO [1959] 2007, p. 320-321-322).

Como visto, para Delfim, o mercado cafeeiro era - de fato - intrinsecamente instável, o que fazia a própria economia brasileira também o ser, e com propensão a aumento da instabilidade. Estas pequenas diferenças de análise entre Celso Furtado e Delfim resultariam em aplicações de políticas diferente. Furtado, ao aderir sua análise a um modelo "Lewisiano", não percebe o salário real como sendo custo para a indústria. Pelo ao contrário, como o salário real não aumentaria (dada a oferta super elástica de mão-deobra), isso refletiria na indústria, perdendo mercado interno e impedindo o desenvolvimento industrial. Para Delfim, o salário estaria sempre pressionando a produção. Fosse ele a de café, fosse a industrial nas cidades. Dessa forma, o salário (muito alto) seria um impeditivo para o desenvolvimento industrial. E, o salário, como vimos, tem o seu custo que depende fortemente da entrada de divisas. Assim, o câmbio não só é um fator de custo para os industriais - do qual o café seria importante - como também, custo ao trabalhador para a sua reprodução, o que refletiria em uma necessidade de maior salário. 
Nesse sentido, as políticas propostas pelos dois autores, para o Brasil, seriam diferentes. Furtado, então, proporia uma reforma agrária, dessa forma, eliminando a "oferta infinita" de mão-de-obra e forçando que o salário real aumentasse para os trabalhadores das indústrias (em outras palavras, diminuir-se-ia o "exército de mão de obra de reserva"). Já, para Delfim, a única forma de manter os salários sem pressionar os industriais de forma a atrapalhar o desenvolvimento industrial, seria o aumento da produção. Tanto para exportação, quanto da produção de mais alimentos (os bens de consumo de salário). A partir do momento no qual se conseguisse baratear a produção industrial (contendo os custos para a reprodução da vida do trabalhador), e se aumentar a entrada de divisas, também se conseguiria baratear os produtos destinados ao consumo dos trabalhadores. Aqui, lembramos a passagem do capítulo primeiro desta dissertação, quando se trouxe à baila a explicação de Delfim para a inflação, e a sua referência ao livro de BrescianiTurroni, trazendo a necessidade de uma maior produção de bens essenciais para o consumo e não bens supérfluos ${ }^{111}$.

Assim, a proposta do Delfim é desenvolver ao máximo a produção, para aumentar ao máximo o consumo dos trabalhadores por meio do barateamento desenvolvendo ao máximo os setores modernos de produção. Já, para Furtado, a reforma agrária iria incentivar que os industriais repassassem parte de seus ganhos aos trabalhadores, aumentando o mercado interno simplesmente por uma nova redistribuição da renda já existente.

Pode-se, em especial, salientar três pontos de profunda diferença entre Delfim e Furtado quanto da análise nesses dois livros aqui discutidos: 1. O papel da inflação no processo do desenvolvimento e a sua relação com o café; 2 . A forma pela qual se daria a superação da restrição externa ao desenvolvimento; 3. A elasticidade da oferta de mão de obra no Brasil.

A mão de obra no Brasil é analisada - já no fim do século XIX - diferentemente entre os autores. Para Furtado, a expansão da cafeicultura fora possível, pois sempre que houvera um estímulo externo de aumento do preço do café, esse era todo refletido como aumento de lucro ao empresário, o qual aumentava a sua produção sem grandes preocupações com

\footnotetext{
111 “A respeito é interessante a seguinte observação de Turroni: 'Na fase mais aguda da inflação, a Alemanha ofereceu o grotesco e ao mesmo tempo trágico espetáculo de um povo que em vez de produzir alimentos, fazendas, sapatos e leite para seus próprios filhos, estava acabando as suas energias fabricando máquinas ou construindo fábricas"' (DELFIM NETTO, 1958n, pp. 144).
} 
a falta de mão de obra. Já para Delfim, isso não acontece: haveria uma escassez de mão de obra no Brasil, a qual, assomada ao fato de grande parte do consumo deste trabalhador ser importado (ponto em acordo com Furtado), impediria que a taxa de lucro do empresário fosse sempre crescente, mantendo-se um equilíbrio entre salário real e lucro:

\footnotetext{
Inicialmente os custos de produção do café, não cresceram na mesma proporção que a desvalorização cambial; por sua vez, o rendimento residual, que é o lucro, expandiu-se. À medida, entretanto, que a situação se ajustava e dada a importância maior do comércio exterior no custo da vida naquele tempo (em que se importavam quase todos os gêneros de consumo), também os salários tendiam a crescer, crescimento esse que era pressionado ainda pela falta de mão de obra, escassa diante das possibilidades de expansão da lavoura cafeeira. É importante notar-se que essa escassez persistiria mesmo depois que os preços do produto tivessem caído, pois as novas áreas plantadas exigiam um volume proporcionalmente maior de braços e a taxa de entrada de imigrantes havia diminuído (DELFIM NETTO, [1959] 2009, p. 49, grifos meu).
}

Essa diferença de hipóteses é fundamental: para Furtado, haveria sempre um problema de mercado interno, pois os ganhos da produtividade nunca seriam repassados aos trabalhadores. Já, para Delfim, o problema seria de outra natureza, de custo à indústria. Em um, há uma hipótese de "ilusão monetária", a qual permitiria que o trabalhador da cafeicultura não aceitasse seu salário ser comprimido nominalmente, mas o aceitaria, de maneira real. Enquanto que, para Delfim, a compressão do salário (em momentos de crise na cafeicultura), dar-se-ia nominalmente, mas não em ponderação real. O que o colono/trabalhador perdesse em salários reais, ele poderia obter dispensando parte de seu tempo dedicado à lavoura de café, e alocá-lo para outras atividades.

Um ponto interessante é analisar qual a força esses "assalariados" tinham na condução da economia. Para Furtado, o Convênio de Taubaté havia sido uma resposta à desvalorização cambial que comprimia o salário (em especial) das classes médias urbanas. Estas teriam, então, algum poder de incômodo para as "classes dirigentes" do país terem de tomar atitudes frente a elas. Contudo, elas aceitaram seu salário real ser comprimido durante bastante tempo, ao visto, sem poder de ação, e se acomodaram por um tempo após o convênio. Para Delfim, ao contrário, o convênio de Taubaté aconteceu única e 
exclusivamente para garantir aos produtores de café a manutenção de seu posto favorecido no Brasil ${ }^{112}$.

Essa situação, para Delfim, parece se perpetuar até 1959 (ano em que escreve), pois a defesa do café impediria que recursos fossem liberados, não só a mão de obra para a indústria, como, também, os investimentos empresarias somados à mão de obra para a produção de outros bens. Não só de subsistência para a mão de obra (bens de salário), também, para a produção de outros bens para a exportação, o qual reverteria positivamente no barateamento da mão de obra, que contava, em sua cesta, com muitos produtos importados. Mas uma vez, a solução estaria em fazer aumentar a entrada de divisas.

Furtado não é exatamente claro (em Formação) se essa situação de oferta "infinita" de mão de obra mantinha-se até o momento no qual escrevia o livro. Mas para ele parece um problema muito grande os traslados de trabalhadores nordestinos para o sul industrial, questão que ele quer resolver mudando as estruturas "arcaicas" de produção do nordeste. Nesse sentido, devemos entrar no outro tópico de discordância: a possível superação da restrição externa. Para Furtado, fica claro que essa superação se dará ao se substituir ainda mais fortemente a importação de bens de capital, por uma produção nacional destes. Não fica muito claro como esse aumento de produção se daria. O capítulo 36 do Formação, Perspectiva dos Próximos Decênios, apresenta-se como se houvesse duas partes interligadas. Na primeira, discute-se que o processo de desenvolvimento de um país é dado pela mudança do centro dinâmico da economia: do impulso externo, e, paulatinamente, para o interno. O Brasil já estaria em um período no qual uma "redução brusca da procura externa já não afeta necessariamente o nível de emprego do país" contudo "seu efeito na taxa de crescimento é imediato" (FURTADO, [1959] 2007, p. 327), refletindo a não superação da restrição externa. A superação disso seria, exatamente, o aumento da produção de bens de capital. Ao invés de explicar como, então, poderia ocorrer no Brasil esse aumento de produção, ele logo em seguida diz: "Observado de um ângulo distinto, o desenvolvimento da primeira metade do século XX apresenta-se basicamente como um processo de articulação das distintas regiões do país em um sistema

\footnotetext{
${ }^{112}$ A manutenção do valor cambial serviria, então, na análise de Delfim, para reter os ganhos das operações de compra do café junto aos produtores.
} 
com um mínimo de integração" (FURTADO, [1959] 2007, p. 328). Ou seja, foi pelo aumento do mercado interno que se permitiu que o Brasil se desenvolvesse.

Passa, então, a descrever como o atraso do Nordeste, com estruturas arcaicas, impediria o desenvolvimento do país. E essas estruturas arcaicas são mantidas exatamente pelo certo nível de integração do país, o qual impediu as indústrias nordestinas de se perpetuarem, perdendo para as de São Paulo. A única conclusão que se pode chegar é que Furtado quer que o aumento do mercado interno se dê ao se acabar com as "estruturas arcaicas" do Nordeste, transformando os trabalhadores em consumidores, aumentando-se o mercado das indústrias, e se aumentando, portanto, a necessidade de consumo de bens de capital. Já para Delfim, a restrição externa é fundamentalmente o que impediria o Brasil de se desenvolver, e deveria ser combatida com o aumento de exportação de outros bens. Sejam agrícolas, sejam industriais. Nesse sentido, é que se identifica a última divergência entre os dois autores: o papel da inflação no desenvolvimento brasileiro nesse período. Para Furtado, como visto, a inflação é o agente (no pós Guerra) que permitiria a transferência de renda do setor exportador ao setor industrial (com o subsídio à importação de maquinários). Ela é, inclusive, esperada quando o processo de desenvolvimento continua e se tem uma forte restrição externa. Para Delfim, a inflação estaria atuando em sentido oposto àquele discutido por Furtado: a inflação seria a forma como a economia encontrara de impedir que os recursos saíssem da cafeicultura. Pois, a compra do café, ao ser realizada por emissão de papel-moeda, atuava no sentido de desvalorizar-se o câmbio, incentivando ainda mais a produção de café. A maior produção de café se refletia em: i) menor entrada de divisas - diminuindo o desenvolvimento brasileiro - e exigindo uma maior intervenção no período seguinte, a qual exigiria mais emissão de papel moeda; e, ii) a retenção de recursos da economia na produção de café, que significaria maior custo para o resto da economia, e, portanto, maior inflação.

Entende-se que somente um governo de "força", como teria sido o de Getúlio Vargas para Delfim, conseguiria atuar no sentido de se ir contra os interesses dos produtores de café, penalizando os menos produtivos com a queima (e, portanto, os obrigando a atuar em outras atividades) e direcionando a economia para que conseguisse encontrar uma salvação sã para a dependência deletéria da economia cafeeira. É, exatamente, a falta de um governo de força, para eliminar a produção inaproveitável de café, e a frouxidão de 
um governo demagogo que tenta agradar a $\operatorname{todos}^{113}$, tanto cafeicultores ${ }^{114}$ quanto industriais que causaria a inflação. Essa inflação comprometeria a economia, ao se dificultar a busca de alternativas ao café, condenando-a, no limite, a um aumento da monocultura. Como o café era o grande entrave do desenvolvimento brasileiro, a política do governo estaria condenando o Brasil. Assim, a tentativa de se ajustar a várias demandas da população, criava uma política demagoga que não levava a lugar algum. Empurrava-se de um lado ao outro, sem se sair do lugar.

Já para Furtado, nessa interpretação, a saída encontrava-se na ampliação do mercado interno, a qual possibilitaria a maior expansão da indústria, e finalmente, o livramento do impeditivo externo ao desenvolvimento. Essa ampliação, então, estaria localizada em especial no Nordeste, o qual ainda padecia de estruturas arcaicas e que não se mudaria facilmente. Qual uma boa forma de se tirar o poder do setor ligado à exportação, e dos arcaicos produtores nordestinos? Destinar esse poder aos consumidores dos produtos produzidos nacionalmente.

Com essa exposição de fatos, pode-se tentar entender por que para um autor, a democracia se fez, depois, como fator de grande preponderância para o desenvolvimento do país, e por que, ao outro, o desenvolvimento pode ocorrer, sendo considerado o " $C z a r$ " da economia. Situação a qual se entende (ou, se lhe é atribuído) que todas as decisões são tomadas de cima para baixo, removendo-se todas aquelas querelas que impediam a melhor alocação de recursos ao desenvolvimento. Para ambos, parece que a demagogia estaria presente. Contudo, para um, a resposta pode ser um governo de força, e, para outro, parece ser, um maior aumento da participação popular. Essa participação, inclusive, ajudaria no plano de maior distribuição de renda, aumentando o mercado interno. Para Delfim, a distribuição de renda não entrava em discussão, pois o mercado interno deveria

\footnotetext{
${ }^{113}$ Delfim escreve um ano antes de publicar esse livro: "o governo, (...) pode continuar calmamente em sua política de déficits orçamentários (...) pois a inflação dá uma impressão de prosperidade geral" (DELFIM NETTO, 1958n, pp. 142, grifos meus).

${ }^{114}$ Também escreveu: "O Sr. Juscelino Kubistchek adiou, de fato, a "marcha da produção" sôbre o Rio de Janeiro, mas teve de por isso um preço que ainda não se sabe ao certo qual será.". DELFIM NETTO, 1957 m, p. 65). A "marcha da Produção" foi um movimento formado por cafeicultores, idealizado apenas, que intencionava marchar em caravana até o palácio do catete no Rio de Janeiro em outubro de 1958 contra as políticas adotadas para o café, em especial o "confisco cambial". Em sua maioria, era um movimento de produtores do Paraná. Liderados por Álvaro Godoy, residente de Londrina e Presidente da Associação dos Lavradores do Norte do Paraná. Cf.: Cesário e Nolli (2009).
} 
servir como subsidiário, diminuindo o custo para às exportações, permitindo um maior número de entradas de divisas, o que aceleraria o desenvolvimento econômico brasileiro. 


\section{Capítulo 4: O economista à porta de Brasília: escritos dos anos 1960}

Neste capítulo são discutidos os textos dos anos 1960 escritos por Delfim. É importante sempre ter em mente o cenário político atribulado no qual Delfim se encontrava; renúncia de Jânio Quadros, querelas sobre a assunção de João Goulart e o golpe de 1964. Neste período iremos analisar as perspectivas de Delfim em relação ao Planejamento e sua necessidade para a continuidade do desenvolvimento econômico, a pretensa forma correta de conduzir a agricultura brasileira naqueles anos para que esta colaborasse no desenvolvimento brasileiro, e, por último, a perspectiva (bastante singular) de inflação para Delfim.

Delfim, apesar de contrário ao governo JK, não concordava com as medidas propostas por Jânio Quadros, em especial quanto à Sumoc 204 que implantou uma desvalorização de todo o câmbio, inclusive do câmbio de custo. O grande problema apontado por Delfim no governo JK (considerado demagogo/populista) poderia ser contornado com um planejamento econômico eficiente. O papel do planejamento econômico seria - entre alguns outros - a "conciliação de classes". As diferentes classes na economia teriam "vontades egoísticas" que atravancariam o desenvolvimento. Caberia ao planejador impedir que essas vontades se manifestassem, levando sempre em conta a transformação da estrutura econômica em direção ao desenvolvimento, o qual não é tido como um simples aumento da renda per capita, mas sim a alteração das mudanças estruturais e produtivas, tendo na industrialização condição sine qua non para a sua realização. $\mathrm{O}$ consumo - em proporção da renda - diminuiria como condição básica para o desenvolvimento, assim, como também se faria necessário o aumento do investimento em proporção da renda - para atingir tal fim. Assim, onde a contabilidade nacional poderia ver um aumento da concentração de renda (retorno do salário em comparação do retorno da renda de capital) na verdade (na teoria) isso não se aplicaria, pois, parte desse "maior" retorno do empresário na verdade refletiria um maior investimento em produção, cabendo ao planejamento impedir que esse maior retorno se transformasse em consumo, e que fosse invertido produtivamente. Sobrando, ao consumo dos assalariados e dos empresários a mesma proporção de outrora, não havendo, assim, "concentração de renda" e nem "perda salarial".

Delfim, ainda, tem uma visão de que o desenvolvimento só poderia ser atingido com um aumento de produtividade no setor agrícola grande o suficiente para que se liberasse 
recursos (mão de obra principalmente) para o setor urbano. Contudo, discorda dos diagnósticos do Plano Trienal e do PAEG os quais propunham a reforma agrária como necessária ao desenvolvimento brasileiro. Para Delfim, já haveria desenvolvimento capitalista no campo, não sendo necessário a reforma agrária. O campo deveria aumentar a produtividade, e, se este aumento estivesse realmente acontecendo de maneira a atrasar o desenvolvimento industrial, não se devia a uma "estrutura arcaica" de produção, mas, sim, devido a formas oligopolistas no comércio, as quais impediriam que os ganhos de produtividade do campo fossem retidos pelos fazendeiros. Ainda mais, a reforma agrária não aumentaria o mercado para os produtos industriais, porque boa parte do aumento da produção seria consumido dentro da própria unidade, demorando ainda mais para integrar a economia de mercado. Seria necessário um “consumo de massas” o qual só ocorreria com um processo ainda maior de urbanização; a melhor forma de se aumentar o mercado interno, seria, então, com uma maior industrialização.

Negando a necessidade de reforma agrária, Delfim se colocava em posição política oposta àquela tida pelos "estruturalistas" no Brasil. Todavia, a definição de "Escola Estruturalista" não é clara, a qual contava com tantas diferenças intra se (Sunkel/Prebisch/Furtado) que ficaria difícil fazer uma linha de corte entre diagnósticos daquela escola, ou não. Este ponto poderia refletir uma grande heterogeneidade de pensamento à época (porque mesmo autores considerados diferentes eram colocados em escolas de pensamentos iguais), ou uma grande homogeneidade de pensamento (dado que as diferenças específicas seriam muito pequenas). O Plano Trienal, e.g., não seguiria o diagnóstico de inflação de Sunkel, no qual afirma, entre outras coisas, a necessidade de maior controle de reajuste salarial e direcionamento da produção para aumento da exportação e diversificação desta. Delfim se afastaria propositalmente da "escola estruturalista", ao também se utilizar de uma linguagem "mainstream", e trazer à discussão autores economistas como argumento de autoridade. Mas seu diagnóstico da inflação difere, aparentemente, ligeiramente deles, resultando em diagnósticos bastante diferentes. Por exemplo, ao se comparar com o diagnóstico do PAEG, Delfim é claramente opositor quanto à política agrária, e quanto à política monetária de combate à inflação. Para Delfim, seria necessário aumento da produção de bens de salário (por isso aumento da liquidez disponível, e não contração como fez o PAEG), direcionamento da economia para exportação, e, imposição para a manutenção da participação dos grupos na renda; nem assalariado nem empresário poderiam aumentar sua participação no 
produto. Reforma agrária não resolveria o problema da industrialização, nem da inflação e nem do desemprego.

\subsection{Introdução}

A história do Brasil, na década de 1960, é geralmente lembrada pela mudança de regime que ocorreu com a ascensão dos militares em 1964. Contudo, mesmo sendo essa data importante para o objeto de estudo aqui apresentado, devem-se tecer alguns comentários sobre os anos que precederam o 31 de março daquele ano. "Em 31 de janeiro de 1961 Jânio Quadros assumiu a Presidência da República amparado pela mais significativa votação popular que registra a história das eleições brasileiras” (ABREU, 1990, p. 198) Essa expressiva votação que o recém presidente recebera (com um discurso bastante crítico ao governo de Juscelino) era um indicativo de um grande descontentamento da população com a gestão anterior ${ }^{115}$. Certamente pode-se afirmar isso, com mais exatidão, do que necessariamente devido ao entusiasmo aos remédios propugnados pela nova gestão.

Naquele contexto, a Faculdade de Economia da Universidade de São Paulo instituiu uma matéria para se discutir o que seria o governo Jânio Quadros. Este curso, tendo como professor responsável Dorival Teixeira Vieira, partiu de uma demanda "popular", de grupos paulistas querendo um "estudo e divulgação" do programa econômico do novo presidente, antes de ele tomar posse ${ }^{116}$. Esse estudo é bastante elogioso quanto ao diagnóstico econômico do novo presidente: “O Dr. Jânio Quadros revelou conhecer a existência de profundos desequilíbrios regionais na economia brasileira" (VIEIRA, 1961, p. 01). Não se pode afirmar peremptoriamente que o professor Vieira representava parte expressiva da população paulista. Contudo, é mais um indicativo de que havia grupos que estavam muito descontentes com a administração de Juscelino Kubitschek. Não há, ao longo de todo o curso, um elogio à gestão JK. Muito ao contrário:

Não escapou ao Dr. Jânio Quadros a percepção de que o seu novo posto exigirá extraordinário sacrifício, pois, gigantesca é a herança dos erros acumulados. A produção, em todos os setores, mesmo no industrial, se

\footnotetext{
${ }^{115}$ É necessário se lembrar que à época não era feito um segundo turno para as eleições presidenciais. Dessa forma, os $48 \%$ de votos recebidos eram considerados muito expressivos. O segundo lugar (General Lott, do PSD) recebeu 28\% (VILLELA, 2011, p. 38).

116 Diz o texto sobre o curso: "A presente publicação resultou de um curso realizado na Faculdade de Ciências Econômicas e Adminsitrativas sobre A Futura Política Econômica e Financeira do Brasil. A ideia de sua organização partiu do "Movimento de Arregimentação Feminina", ao consultar o Departamento de Cultura da Universidade de São Paulo sobre a possibilidade do estudo e divulgação do programa do Presidente eleitos da República, para que o povo paulsita dele tomasse conhecimento, a fim de melhor participar de sua realização, durante opróximo período presidencial” (VIEIRA, 1961, p. I).
} 
vê desamparada, por falta de trabalho especializado, de capital técnico e principalmente de crédito. O governo do Sr. Juscelino Kubitschek, não contente em provocar uma inflação monetária, agravou-a com uma descomedida expansão de crédito. Deste modo, o dinheiro se torna, ao mesmo tempo, mais abundante e mais escasso.; sobra para aplicações irreprodutivas, capazes de suportar astronômicas taxas de empréstimos; falta quando se destina à produção (VIEIRA, 1961, p. 03-04).

O governo conseguiu - na visão do autor - aumentar a inflação com descomedida expansão de crédito e ao mesmo tempo escassear o crédito para à produção. Assim, este descontentamento se assemelha muito com a interpretação de Delfim: um governo que não agradou ninguém, e acabou "desregulando a vida de todos". O Governo do Jânio Quadros, além disso, opunha-se ao governo anterior por ter uma "afirmação de fé neoliberal" (VIEIRA, 1961, p. 04) e ser "frontalmente contrário às ditaduras" (VIEIRA, 1961, p. 04).

Jânio Quadros, apesar de filiado ao PTN (Partido Trabalhista Nacional), era apoiado pela UDN (União Democrática Nacional), partido notoriamente conhecido como opositor a Getúlio Vargas, ao "getulismo” e, na oportunidade, ao governo de Juscelino Kubitschek (BENEVIDES, 2010). Sua campanha concentrou-se no discurso pela diminuição da inflação e pelo reestabelecimento da moral, que, com a sua famosa vassoura, pretendia "varrer" para longe a corrupção que teria sido instaurada pela gestão anterior. Além disso, ressalta-se que o famoso livro "Os Donos do Poder" de Raymundo Faoro fora lançado em 1958, ressaltando que o desenvolvimento ficava relegado "aos amigos do Rei"; clara alusão a JK e sua relação "íntima” com os empresários e, em especial, as construtoras no momento ${ }^{117}$. A construção de Brasília fora muito criticada pelos escândalos de corrupção que haviam sido notificados pela imprensa à época. Já, na área econômica, Vieira - ao analisar os discursos do governo de Jânio Quadros - afirma que os objetos seriam dois; o primeiro, "incrementar a taxa de formação interna de capital", e o segundo, "ampliar a pauta de exportação brasileira" (VIEIRA, 1961, p. 12). Dessa forma, pode-se entender essa votação expressiva de Jânio Quadros como uma resposta ao resultado não satisfatório do desenvolvimento econômico, sobre o qual, crer-se-ia ter como base a corrupção e a restrição externa.

Assim, quando se analisam os ditames efetivamente realizados por aquela gestão, destaca-se a reforma cambial, por meio da Instrução N ${ }^{\circ} 204$ da Sumoc. Essa instrução, lançada em 13 de março de 1961, desvalorizou o câmbio, significando um aumento em

${ }^{117}$ Sobre o assunto, conferir, e.g., Campos (2017) e Campos (2012). 
$100 \%$ do preço do câmbio de custo ${ }^{118}$. Pouco tempo depois, em 27 de junho, editou-se a Instrução 208, a qual unificava o câmbio (na prática uma desvalorização ainda maior para a importação) em uma só taxa. Passava-se, portanto, a se ter a mesma taxa cambial para todas as transações, fosse importação, exportação ou câmbio de custo. Ao que tudo indica, essa desvalorização cambial tinha como objetivo o controle da inflação, ao não obrigar o governo a realizar emissões para cobrir o défice do Tesouro e nem o do Balanço de Pagamentos ${ }^{119}$. Além da pura desvalorização cambial, as importações foram dificultadas por exigirem depósitos compulsórios sobre as mercadorias importadas e as remessas financeiras. Essa política era bem vista aos olhos do FMI, e ajudou na renegociação da dívida brasileira ${ }^{120}$.

Como visto ao longo dessa dissertação, Delfim durante a década de 1950 manteve em seus artigos uma posição muito contrária ao governo JK e a sua política inflacionária em especial no concernente às compras governamentais de café. Mas, também, ele era bastante crítico à desvalorização cambial, dado o custo que ela traria à produção, pois oneraria as indústrias e as outras atividades, tornando ainda mais difícil realizar uma produção competitiva para a exportação. Assim, não vemos como ele pudesse estar alinhado com as propostas de Jânio Quadros (candidato apoiado pela UDN), mesmo crítico da gestão anterior (JK). Não se achou nenhum comentário de Delfim em relação à Instrução 204 da Sumoc, contudo, a única inferência que se pode ter é de que ela colidiria frontalmente com o diagnóstico de Delfim. Mesmo este reiteradamente afirmando que o problema do Brasil era conseguir aumentar as exportações.

As políticas postas, então, em prática, não resultaram nos objetivos advogados pelo governo: como melhora do balanço de pagamentos e diminuição da inflação. Houve, na verdade uma piora substancial nesses quesitos. Há, entretanto, um impasse na análise do motivo desta piora, dado os acontecimentos políticos que se desenrolaram logo em seguida. Àqueles que defendiam a política econômica posta em prática, o seu insucesso

\footnotetext{
${ }^{118}$ Eram beneficiadas pelo câmbio de custo as importações e papel de imprensa e papel para editora de livros, fertilizantes, inseticidas, etc., trigo, petróleo e derivados, e importação de equipamentos, peças, etc, sem similar nacional, para empresas jornalísticas, editoras de livros e para investimentos considerados essenciais ao processo de desenvolvimento e à segurança. $\mathrm{O}$ mesmo tratamento era dado para pagamento de compromissos financeiros de governos não ligados a importações, serviços relativos à pesquisa e produção de petróleo, e amortização e juros de empréstimos, créditos e financiamentos de interesse para a economia, ou relativos a importação de equipamentos para petróleo, empresas jornalísticas ou editoras, ou para investimentos considerados essenciais ao desenvolvimento ou a segurança. (MUNHOZ, 2012, p. 46) 119 A inexistência de recursos do Fundo de Ágios compatíveis com o acúmulo de obrigações governamentais em divisas relativas a atrasados, "swaps" e importações a câmbio de "custo".

${ }^{120}$ Cf, Abreu, 1990, p. 199-200 , Villela, 2011, p. 39-40 e Munhoz, 2012, p. 47-48.
} 
devia-se à tensão política que se criou com a renúncia de Jânio Quadros e a sucessão latente (que posteriormente se concretizou) de seu vice-presidente, João Goulart (exministro do trabalho de Getúlio Vargas, visto como responsável, entre outros fatos, pelo aumento de $100 \%$ do salário mínimo em 1954). Àqueles que a criticam, o balanço de pagamentos tinha suas importações muito rígidas, em especial trigo e petróleo, e um encarecimento desses produtos diminuiria muito pouco o volume importado. Resultando, apenas, em um aumento de preços para a economia ${ }^{121}$.

O fato que se deu foi um momento político muito delicado com a renúncia de Jânio Quadros, pois havia o receio de impedirem João Goulart - legalmente sucessor - de assumir a presidência ${ }^{122}$. Frente a essas tensões, o congresso encontrou uma "saída": transformar o Brasil em um sistema parlamentar, fazendo Tancredo Neves Primeiro Ministro, minimizando, assim, os poderes do presidente. Em 6 de janeiro de 1963, após o Brasil ter tido mais 3 Primeiros-Ministros ${ }^{123}$, foi realizado um plebiscito sobre qual deveria ser a forma de governo. O presidencialismo ganhou, e João Goulart assumiu. O novo governo teve San Tiago Dantas como Ministro da Fazenda e Celso Furtado como Ministro do Planejamento, este fora responsável por encabeçar o "Plano Trienal", que orientaria a política econômica do governo ${ }^{124}$.

No que tange à inflação, este Plano concentrou-se em aumentar a arrecadação pública e em diminuir o dispêndio programado do Governo. Esses objetivos deveriam ser alcançados, em especial, com aumentos de impostos, redução de subsídios, corte de despesas, "realismo cambial", controle de expansão de crédito ao setor privado, aumento do compulsório sobre depósitos à vista e correção de tarifas de serviços públicos ${ }^{125}$. Foi um plano que surpreendeu pelo seu caráter "convencional" (MACEDO, 1975, p. 59) e “ortodoxo" (VILLELA, 2011, p. 42 e ABREU, 1990, p. 206). No tangente às restrições

\footnotetext{
${ }^{121}$ O PIB em 1961 cresceu consideravelmente (muito em razão da maturação dos investimento do ano anterior) mas a inflação teve uma elevação de 30,5\% em 1960 para 47,8\% em 1961 (VILLELA, 2011, p. 41).

${ }^{122}$ Esse medo advinha do veto Militar à posse do vice-presidente, organizado pelos três ministros militares: general Odylo Denys, do Exército, almirante Sílvio Heck, da Marinha, e brigadeiro, Grün Moss, da Aeronáutica, alegando que a investidura de João Goulart feriria a segurança nacional. Contrários ao veto estavam alguns governadores de estados, em especial Lionel Brizola que afirmou que garantiria a posse do presidente (seu cunhado) nem que fosse necessário recorrer à bala (VILLELA, 2011).

${ }^{123}$ Auro de oura Andrade, Brochado da Rocha e Hermes Lima.

124 O Plano Trienal, elaborado em poucos meses, foi apresentado no final de dezembro de 1962, sob a elaboração de Celso Furtando ainda ministro extraordinário para Assuntos do Desenvolvimento Econômico.

${ }^{125}$ Para mais detalhes, cf. BAER, 1962; MAGALHÃES, 1962; VILLELA, 1962; COSTA, 1962; BAER et Al, 1962.
} 
externas, tudo indica que o Plano apostaria na continuidade da política de industrialização por substituição de importações para superá-las ${ }^{126}$ e pouco caminharia no sentido de estímulo às exportações ${ }^{127}$. Tudo indica que a nova gestão esperava conseguir uma renegociação das dívidas como fora conseguido no governo de Jânio Quadros. Contudo, isso não se deu ${ }^{128}$. Resultando em um agravamento ainda maior no balanço de pagamentos $^{129}$. Macedo faz uma boa síntese do Plano:

Considera o Plano que, isolado (!) [sic] o problema da política salarial e o comportamento do setor externo, a possibilidade de corrigir o desequilíbrio inflacionário iria depender bàsicamente da forma de financiar o déficit do Tesouro sem prejudicar a taxa de crescimento da economia (MACEDO, 1975, p. 58)

Por outro lado, o plano detinha um caráter não convencional: a reforma agrária ${ }^{130}$ como forma de superar o suposto atraso no campo, o qual se refletia em uma produção de alimentos não suficiente ao desenvolvimento urbano/industrial no qual o Brasil precisava. Chegar-se-ia a essa conclusão ao se analisar a relação de troca entre a agricultura e a indústria, derivados dos deflatores de preços implícitos destes setores. Dessa forma, o plano exibe que houve um ganho de produtividade do setor agrícola cedido pelo setor urbano, diminuindo, assim, os recursos a serem investidos na indústria. Pois, devido a um "arcaico" sistema de propriedade da terra, os grandes proprietários da terra não se interessariam em reinvestir na produção. Então, o maior ganho da agricultura teria sido absorvido pelos proprietários - por meio de arrendamentos mais altos - transformando esses aumentos relativos de preços em maiores rendas e maior consumo pelos donos da terra. "Portanto, a causa básica da rigidez da oferta, que se revela na relação de troca, é o sistema agrário, sendo principalmente pela modificação dessa estrutura que se poderá obter uma oferta mais elástica" (SMITH, 1962, p. 113).

\footnotetext{
${ }^{126}$ Cf Macedo (1975, p. 55).

${ }^{127}$ Huddle (1962) vai ainda mais além, criticando as projeções que o plano teria feito ao crescimento do aumento em divisas dos produtos já tradicionais de exportação do Brasil. Em especial, o plano sobrevalorizaria os valores que seriam conseguidos com a exportação do café, algodão, cacau e madeira sem especificar como se daria isso.

${ }^{128}$ Dois são os motivos apontados como mais prováveis a rejeição da negociação das dívidas; i)medo de um governo muito "à esquerda"; e, ii)insatisfação com a "Lei de Remessa de Lucros (Lei n 4.131) de 3 de setembro de 1962. Essa Lei limitava em 10\% sobre o capital registrado as remessas de lucro ao exterior.

${ }^{129}$ Há toda sorte de interpretação para o Plano Trienal não ter sido considerado exitoso a qual foge ao escopo desta monografia.

${ }^{130}$ Apesar de Fonseca $(2004$, p. 608) insistir que o plano tinha um caráter monetarista, mas também, um forte caráter estruturalista, resultando em um "diagnóstico eclético" e, portanto "não-estranho à heterodoxia latino-americana no século 20". Ressalta-se, como Bastian (2012) o faz, que a "política salarial do PAEG" era a única real diferença entre os dois planos. Podendo, assim, ser também classificado como heterodoxo por verossimilhança ao raciocínio de Fonseca (2004). A presente dissertação, contudo, foge a essas classificações.
} 


\subsection{O Planejamento}

\subsubsection{Contextualização}

Sucintamente, é nessa contextualização do que se passava na economia e na política à época que devem ser analisados os escritos de Delfim. O planejamento (ou a programação econômica) era quase que um consenso entre os economistas brasileiros na década de $1960^{131}$. Incluindo Delfim. Contudo, o termo estava em disputa. Àqueles que se utilizavam do termo "programação econômica" (ou variantes similares) havia uma tentativa de se afastar de um modelo "soviético" ou "comunista" de racionalização/centralização da economia. Por outro lado, aqueles que defendiam o termo "planejamento econômico" não se mostrariam, assim, tão preocupados com essa distinção ${ }^{132}$. Sobre o termo programação da economia, diz-nos Rangel, um dos "colaboradores" do "Programa" de Metas:

$\mathrm{Na}$ esteira da II Guerra Mundial, a ideia do planejamento econômico granjeou, no Brasil, como em todo mundo, imensa popularidade. $\mathrm{O}$ brilhante desempenho da economia soviética, nas duras condições impostas pelo conflito não foi estranho a isso (...). Entretanto, nas condições da guerra fria, tudo o que pudesse sugerir a aprovação a qualquer coisa que os soviéticos fizessem foi posto no index, de modo que os economistas ocidentais - entre os quais o planejamento, apesar de tudo, não havia perdido seu prestígio, passaram a usar o termo programação, para significar a mesma coisa. Foi assim que, sob Juscelino, tivemos um Programa de Metas, não um Plano de Metas. A ideia de planejamento ficou relegada ao campo dos esquemas setoriais, como no caso do Plano de Eletrificação (RANGEL, 1987, p. 25 , grifos no original)

Delfim, nesse sentido, utiliza, sem titubear, em seus escritos na década de 1960, o termo planejamento. Já a "Associação Nacional de Programação Econômica e Social”, Anpes, da qual Delfim participou, utiliza o termo "programação" para descrever a sua atividade $^{133}$. Esta foi uma instituição privada que publicou alguns estudos sobre

\footnotetext{
${ }^{131}$ Uma evidência desse ponto é que na Revista Brasileira de Economia de 1962, todos os autores lá elogiam o fato de que o Plano Trienal é uma tentativa de planejamento. Apesar de muitos terem críticas àquele plano, não o criticam; ao invés, elogiam o planejamento econômico.

${ }^{132}$ Nunca houve, e.g., um "plano de metas" de JK. O que houve, por outro lado, foi um "Programa de Metas". Posteriormente, houve o "Plano Trienal", considerado - à época - de um plano feito por um governo "esquerdista" como o de João Goulart, o que talvez explique a utilização do termo "Plano". Após o golpe, veio o "Programa de Ação Econômica do Governo (PAEG)", proposto por uma gestão que teria vindo para "retirar os comunistas do governo". Após o PAEG, veio, já sob os auspícios de Delfim o "Programa Econômico de Desenvolvimento" (PED). Posteriormente, o que já poderia indicar uma mudança de atitude do governo, é lançado o "Plano Nacional de Desenvolvimento" (PND). Após este, com a saída de Delfim do ministério, é lançado o "Segundo Plano Nacional de Desenvolvimento" (II PND).

${ }^{133}$ A própria instituição diz: "A palavra "programação", ao invés de planejamento, indica que a contribuição da iniciativa privada não pode realisticamente ir além de formular uma visão de perspectiva da economia brasileira, dentro de diferentes hipóteses, sem procurar nenhuma forma de planejamento global que
} 
economia, fundada numa sólida base empírica, no Brasil. Criada em 1964, uma época de escassez de dados domésticos, a ANPES era uma importante contribuição nesse sentido. Para Mario Henrique Simonsen a associação era "financiada por vários empresários, sobretudo de São Paulo". No início - a associação começou antes do Governo Castello Branco - o presidente tinha sido Roberto Campos, e o diretor administrativo era o próprio Simonsen, logo em seguida do golpe de 1964, João Paulo dos Reis Velloso também é integrado "aos seus grupos de estudos" (COMEMORAÇÂO DOS 25 ANOS DO IPEA, 1989). Dessa forma, a tentativa de trazer estatísticas para dentro das ferramentas de decisão governamental estava intrinsecamente presente na construção da associação. ${ }^{134}$ Dos cinco primeiros "Estudos Anpes" publicados, Delfim foi autor de quatro. O primeiro, sobre a Inflação; o terceiro, sobre "O Café no Brasil"; o quarto, uma "Tentativa de explicação das causas que determinaram a expansão de crédito no Brasil”; e, por fim, o quinto, a respeito da agricultura no Brasil ${ }^{135}$.

\subsubsection{O Planejamento para Delfim}

É com o termo Planejamento, que Delfim trabalha ao defender, em 1962, a tese "Alguns Problemas do Planejamento para o Desenvolvimento Econômico" "136 para o concurso de "provimento da Cadeira XXV - Economia Brasileira; Planejamento Governamental; Teoria do Desenvolvimento Econômico" (DELFIM NETTO, 1962). A tese dividida em seis capítulos (mais a apresentação e conclusão) apresenta em cada um deles o desenvolvimento de um modelo econômico formalizado, destacando quais os problemas que poderiam advir a partir dos diferentes modelos. O Planejamento poderia, também, ser visto como uma forma de responder a um sistema político tão volúvel como estava sendo o brasileiro. Dessa forma, o Plano Trienal não fora criticado por Delfim por ser

\footnotetext{
não é compatível com a organização política, social e econômica do País" (DELFIM NETTO, 1965, p. $\mathrm{v}$, grifos nossos).

${ }^{134}$ Não se deve confundir a Anpes com o Ipes/Ibad. Esta última tinha uma conotação política que o primeiro não se propôs a ter. Apesar de muitos dos membros do Ipes também terem participação importante na Anpes, não é possível considerá-los como parte de um mesmo grupo. Conforme Dreifuss: "A 31 de março de 1964, no dia do desencadeamento do golpe, um grupo de diretores de grandes bancos e indústrias criou, em São Paulo, a Associação Nacional de Planejamento Econômico e Social - ANPES -, como parte de um esquema para tornar o associado do IPES e tecno-empresário Roberto de Oliveira Campos o Ministro do Planejamento do novo governo. Roberto Campos, uma figura central da CONSULTEC, professor da Escola Superior de Guerra e ex-embaixador nos Estados Unidos foi eleito secretário geral da ANPES. Outras figuras centrais do ANPES eram Antônio Delfim Netto, do grupo de Doutrina e Estudo do IPES-São Paulo, que passou a secretário geral depois que Roberto Campos se tornou Ministro do Planejamento, e Mário Henrique Simonsen" (DREIFUSS, 1981, p. 425). Outras informações sobre o Anpes podem ser encontradas em (ARANHA, 2016).

135 O relatório Anpes 2 - "O Papel dos Intermediários Financeiros Não Bancários no Processo de Desenvolvimento Econômico" escrito por Pedro Cipollari foi realizado sob a orientação do Delfim Netto.

${ }^{136}$ Posteriormente, essa tese foi publicada em livro (DELFIM, 1966).
} 
planejamento, mas porque seria "mau planejamento". Dito isso, expor-se-á a visão de Delfim quanto às respostas possíveis ao processo de desenvolvimento econômico brasileiro por meio de seus escritos durante esse período de começo da década de 1960. Temas como a restrição externa, a inflação, a industrialização e a agricultura estarão sempre presente, pois são temas que não se separam na prática. Cada um deles afeta direta ou indiretamente os outros.

\subsubsection{Planejamento e a possibilidade de uma terceira via}

Já na introdução da tese, há uma defesa muito elogiosa ao planejamento econômico e otimista quanto às possibilidades de superação do atraso econômico brasileiro. Diz Delfim, que "a crença na capacidade realizadora do país é relativamente nova" (DELFIM NETTO, 1962, p.i) e, ainda, elogia os trabalhos escritos "pela intelectualidade nacional" dos anos 1950, contrastando com o que haveriam sido escritos por ela nos anos 1920 e 1930. Neste último período teriam sido importados "conhecimentos científicos de validade duvidosa a respeito dos fatores condicionantes do nosso desenvolvimento" (DELFIM NETTO, 1962, p. i). Delfim contrapõe a percepção sobre o atraso brasileiro desses dois períodos; em um momento anterior, teria sido feita uma explicação do atraso, permeada de fatalismo. Ora porque procurava-se "provar que uma 'civilização tropical' era uma contradição em termo" ora, ainda, porque "recoberto por uma linguagem pedante, mas vazia de significado, procuravam mostrar que a miscigenação racial constituía o nosso pecado original e que precisaríamos de muitos séculos de sofrimento para expiálo" (DELFIM NETTO, 1962, p. ii). A realidade teria provado que aqueles diagnósticos "nada valiam”, pois, “o sistema econômico nacional não sabia que estava condenado à

pobreza eterna e, não o sabendo, realizava todo o esforço a seu alcance para superar as suas próprias dificuldades" (DELFIM NETTO, 1962, p. ii).

Esse começo do livro de Delfim é realmente importante para a análise, porque já se pode observar-novamente - como "ideias" haveriam sido refutadas pela realidade, a qual teria mostrado que mesmo ao contrário do que a intelligentsia brasileira e mundial pensava sobre a possibilidade de um povo dos trópicos e miscigenado poder atingir graus de desenvolvimento econômico, este teria sido possível. Mais ainda, Delfim demonstra acreditar que qualquer povo estaria livre para escolher sair da miséria, e não haveria "um problema fundador" ou algum "determinismo" que o impediria, utilizando-se para isso a ciência, a qual não precisaria mais se resignar somente a explicar e descrever a realidade, deveria, também, ter um papel fundamental de transformação desta, porque apesar dos 
“modelos" existentes demonstrarem que estávamos relegados à miséria, "felizmente, o sistema econômico nacional não sabia que estava condenado à miséria". A realidade se imporia frente às ideias dos pensadores.

Delfim continua em sua justificativa da necessidade do desenvolvimento, porquanto haveria a necessidade de criação de um modelo novo de desenvolvimento, e a não aceitação, fosse do "capitalismo liberal", fosse do "socialismo", já que "nem o capitalismo liberal nem as implementações conhecidas do socialismo são satisfatórias" (DELFIM NETTO, 1962, p. iv). Cada um desses sistemas padeceria, para Delfim, de problemas fundamentais. No "capitalismo liberal" se teria "a sujeição da coletividade à minoria detentora do poder econômico" (DELFIM NETTO, 1962, p. iv), enquanto no "socialismo soviético" (DELFIM NETTO, 1962, p. iv), o problema seria análogo, pois haveria "essa mesma sujeição à minoria detentora do poder político" (DELFIM NETTO, 1962, p. iv) as quais confundiriam - por meio da "fraude" (DELFIM NETTO, 1962, p. iv) no capitalismo liberal, ou por meio da "força" (DELFIM NETTO, 1962, p. iv) no sistema soviético - "a sua própria vontade, com os verdadeiros anseios da coletividade" (DELFIM NETTO, 1962, p. iv). Nesse sentido, pode-se trazer à baila o argumento discutido no terceiro capítulo desta dissertação, onde se salienta que Delfim estaria combatendo a elite cafeeira retrógrada, a qual, teria amalgamado seus interesses com os pretensos interesses do Brasil. Nesse sentido o planejamento entraria, pois, "esta técnica de administrar recursos" (DELFIM NETTO, 1965, p. 13) permitiria permitir reter o lado bom dos dois sistemas: desenvolvimento econômico rápido e liberdade fundamentais garantidas a cada cidadão (DELFIM NETTO, 1965, p. 12).

Seria possível uma "terceira via", portanto. O capitalismo poderia ser controlado para que a "coletividade" não ficasse sujeita "à uma minoria detentora do poder econômico". O que, então, acontecia, para Delfim, no "capitalismo liberal": "a sujeição da coletividade à minoria detentora do poder econômico". O planejamento, portanto, deveria servir à coletividade $^{137}$. E mais, o mercado como motor da sociedade seria uma "crença mítica, derivada da observação dos países desenvolvidos e não das realidades nacionais" (DELFIM NETTO, 1965, p. 12), resultado de um "entendimento inadequado da realidade" (DELFIM NETTO, 1965, p. 12-13), esta visão de mercado como motor da

${ }^{137}$ É verdade que Delfim não define o que ele entende por coletividade. Claramente, a definição desse termo, e outros, escapariam do trabalho o qual é apresentado. Isso não significaria, necessariamente, uma visão ingênua de Delfim sobre a complexidade da sociedade humana, e suas forças de poder e jogos políticos. Mas, evidencia-se, que essa "coletividade" se põe em oposição à "minoria" detentora do poder. 
sociedade advogaria que seria possível mudanças de estrutura e de comportamento acontecer sem o planejamento. Portanto, é a percepção equivocada da realidade brasileira que levaria "muitas pessoas a combaterem todos os tipos de planejamentos", considerando-os “inúteis ou comunizantes” (DELFIM NETTO, 1965, p. 13). Novamente Delfim chama a atenção para que seja analisada a realidade brasileira, mais do que puramente enquadrá-la num sistema teórico.

O planejamento para Delfim é neutro, apenas um instrumento. Seria possível utilizar o planejamento tanto para "fortalecer a economia de mercado ou para substituí-la" (DELFIM NETTO, 1965, p. 13), i.e., o planejamento poderia vir para "melhorar" o capitalismo, ou para implementar o socialismo. Esses objetivos não dependeriam deste instrumento em si, mas sim, dos objetivos definidos " dentro da esfera do poder político" (DELFIM NETTO, 1965, p. 13). Para Delfim, apesar de ser possível utilizar a ciência para o melhoramento do mundo (e as "técnicas" do planejamento seriam um exemplo), tudo dependeria das decisões políticas, das vontades dos homens e suas ações; não existiria processo automático do desenvolvimento.

Então, se haveria somente vantagens ao planejamento, por que seria preciso a Delfim defende-lo? Ou, ainda, quem estaria contra o planejamento? Para Delfim seriam dois os opositores desta maneira de se direcionar a economia "as classes conservadoras" e "as classes revolucionárias" (DELFIM NETTO, 1965, p. 13). Estas últimas seriam combatêlo-iam, pois, "vendo nele um instrumento eficiente das sociedades abertas para realizarem os ideais do bem-estar social, combatem-no por claras razões de ordem tática" (DELFIM NETTO, 1965, p. 13), i.e., o planejamento conseguiria desenvolver a economia dentro do capitalismo, representando um grande inimigo para aqueles que tendessem suplantá-lo. Já, para as classes conservadoras, por terem uma compreensão "muito inadequada do desenvolvimento, pensando-o, basicamente em termos quantitativos, e atribuindo valor mítico ao mercado" (DELFIM NETTO, 1965, p. 13), considerariam o planejamento inútil.

Deve-se notar como constrói-se um paralelismo entre as "classes conservadoras" e o capitalismo liberal, e as "classes revolucionárias" e o socialismo. Novamente Delfim indica querer salientar uma terceira via, diferente daquelas propostas. Os "socialistas" seriam contra o planejamento - para Delfim - por "ordem tática"; ou seja, como quereriam a implementação do comunismo, eles perceberiam que o planejamento - com os ideiais do "bem-estar" - roubaria o protagonismo da implantação de um sistema 
socialista como o da União Soviética à época. Por outro lado, Delfim esclarece por qual motivo as "classes conservadoras" - que por inferência seriam aquela minoria que sujeitaria economicamente a coletividade - seriam contra o planejamento:

Definido o processo [de desenvolvimento econômico] como aumento persistente do produto nacional líquido per-capita, os economistas têm levado muitas pessoas a acreditarem que o desenvolvimento econômico é um fenômeno puramente quantitativo, que se identifica com o aumento da produtividade da mão de obra. Nada mais longe da verdade, entretanto. $\mathrm{O}$ processo de desenvolvimento econômico se realiza, basicamente, por modificações qualitativas que alteram não apenas a estrutura do sistema econômico, mas também os valores básicos e as formas de comportamento das sociedades tradicionais. O processo de desenvolvimento consiste nesta alteração da estrutura e nesta modificação das formas de comportamento e não no aumento da renda per-capita. Este último fenômeno é apenas o resultado do processo de desenvolvimento e não o próprio processo (DELFIM NETTO, 1965, p. 12, grifos meus).

Dessa maneira, como Delfim expõe seu argumento, o planejamento seria ruim às classes conservadoras, pois, trazendo o desenvolvimento, estas classes teriam seu papel, seus costumes e hábitos mudados. É muito importante frisar o ponto de que o desenvolvimento não seria, para Delfim, um simples aumento de renda per capita. Especialmente, não haveria fórmula utilizada que pudesse ser replicada para a aplicação no Brasil (isso iria contra toda a metodologia de Delfim de análise da realidade específica). Diz ele: "não existe nenhuma obrigação de o desenvolvimento seguir padrões historicamente determinados" (DELFIM NETTO, s.d., p. 262).

Ainda mais, porque cada país teria a sua "classe conservadora" que não seriam, obrigatoriamente, iguais. Com inferimos, seriam elas que subjugariam a economia (impedindo o desenvolvimento), já que se encontrariam em posição privilegiada na sociedade, a qual arriscavam perder. Em suma, as classes conservadoras prefeririam o discurso de "laisser faire" (DELFIM NETTO, 1965, p. 11) por este manter a condição delas de privilégio, impedindo, portanto, o verdadeiro desenvolvimento que seria a mudança de estruturas, e não, apenas, o aumento da renda per capita. É precisamente por esse motivo que Delfim é contrário as políticas do café, como exposto no capítulo terceiro dessa dissertação. Independentemente do aumento (ou não) da renda elas teriam tido o efeito de perdurar classes atrasadas no país, e, logo, teriam impedido o desenvolvimento. 


\subsubsection{Os problemas do desenvolvimento e a necessidade do planejamento}

Tecidas as considerações sobre planejamento e desenvolvimento econômico, e ficando claro que há muitos outros problemas de esfera política a serem resolvidos, Delfim passa então a tratar apenas "[d]os aspectos econômicos do problema". Dentro destes, Delfim discute seis modelos. Em primeiro lugar, discute-se um "modelo muito simples do processo de desenvolvimento (...) analisando depois os efeitos da introdução de uma função de produção (ao contrário do modelo de Harrod-Domar) substituição entre os fatores". No capítulo dois, analisa-se o modelo de Singer (1952) generalizando-o. No terceiro, desenvolve-se "um modelo de desenvolvimento industrial a dois setores que admite como casos particulares os desenvolvidos por Marx (O Capital, vol. II), Mahalanobis (1952), Feldman (Domar, 1957) e Frankel (1961). No quarto capítulo, considera-se o problema da taxa ótima de desenvolvimento, baseando-se em "Ramsey (1928), Tinbergen (1956), Hovart (1960) e Goodwin (1961). No capítulo 5, trata-se do estudo do

Problema do desenvolvimento num modelo a quatro setores, introduzindo as restrições relativas ao equilíbrio do mercado de bens de consumo e bens interediários e mostrando a potencialidade inflacionária e o desequilíbrio latente do balanço de pagamentos que são inerentes aos programas de desenvolvimento que não as levam em conta (DELFIM NETTO, 1965, p. 16)

No último capítulo, o autor discute com o que chama de modelo de Furtado (1958), “demonstrando a compatibilidade entre o desenvolvimento econômico acelerado, o equilíbrio do balanço de pagamentos e o equilíbrio monetário” (DELFIM NETTO, 1965, p. $16)$.

Cada modelo que Delfim constrói no livro tende a ressaltar um aspecto em particular do desenvolvimento. Os capítulos do livro seguem em ordem com o objetivo de introduzir uma nova variável que complexaria gradualmente o problema do desenvolvimento econômico. Todas essas complicações são apontadas em outros escritos, mesmo que dificilmente se as encontre todas juntas como nesse livro. Pode-se dizer que, enquanto o livro do café foi a grande obra de Delfim, por fazer uma análise da economia brasileira e sua relação com seu principal produto, neste livro encontram-se os problemas que o autor via no desenvolvimento da economia brasileira. Serão expostos os principais argumentos dos modelos do livro, e os principais problemas que advém junto com o desenvolvimento. 
O primeiro capítulo, o mais simples, apenas discorre sobre a necessidade de acúmulo de capital e progresso tecnológico para o desenvolvimento obtido. O segundo capítulo trata de um modelo com dois setores e mobilidade de mão de obra entre esses setores ${ }^{138}$. Retoma o argumento feito - explorado nos capítulos anteriores dessa dissertação - de que o desenvolvimento não pode se basear somente na produção agrícola. Pois isso colocaria o país dependente do estímulo externo. Assim, era necessário industrializar (DELFIM NETTO, 1965, p. 38), contudo, a industrialização, ao absorver mão de obra, necessita que o setor agrário evolua em produtividade para prover os alimentos a toda a população, inclusive porque há perda de mão de obra para os setores urbanos com o desenvolvimento, além de investimentos nos serviços e construções públicas.

Mas, o desenvolvimento urbano acontece em taxas muito rápidas, o que "mostra por que no início o processo é difícil e exige investimentos substanciais na forma de construções e serviços públicos, setores onde a produtividade média do capital é baixa" (DELFIM NETTO, 1965, p. 41), indicando a dificuldade do desenvolvimento com a mobilidade populacional e a sua adequação as novas estruturas. E, sem um aumento de produtividade no setor agrícola - o que exigiria modificações tecnológicas substanciais (DELFIM NETTO, 1965, p. 50) - não se poderia haver uma transferência de mão de obra para a indústria, levando a "pressões inflacionárias inúteis para o desenvolvimento, gerando situações de instabilidade social" (DELFIM NETTO, 1965, p. 50). E, para Delfim, essa transferência de mão de obra para a indústria (e, portanto, o desenvolvimento per se como por ele definido) só pode acontecer com o desenvolvimento tecnológico no campo. Salienta-se que Delfim está falando somente que o aumento de produtividade no campo é condição necessária (sine qua non) para o desenvolvimento, mas, não o é, condição suficiente.

O autor analisa, em seguida, também um modelo a dois setores. Só que, ao invés de ser uma dicotomia entre "agricultura e indústria", mais comumente utilizado pela Cepal por meio do modelo de Lewis, é de outro tipo, entre diferentes indústrias: a indústria de bens de consumo e de bens de produção. Diz o autor que o desenvolvimento autêntico (mudanças estruturais que se perpetuem) exige "um crescimento acelerado do setor da

\footnotetext{
${ }^{138}$ Apesar da similaridade com o modelo de Lewis (1954), Delfim está aqui dialogando com o modelo de Singer (1953). Esse fato se dá, porque, Delfim está discutindo uma situação na qual há produtividade marginal na agricultura, ou seja, a perda de mão de obra na agricultura (sem nenhum aumento de produtividade) implicaria um menor produto agrícola. Ao contrário do modelo do Lewis, no qual a produtividade marginal do trabalho na agricultura é nula (ou, aos preciosistas, diz-se que se aproximaria a zero).
} 
indústria de bens de produção" (DELFIM NETTO, 1965, p. 53). Contudo, o investimento nessas indústrias nem sempre se daria assegurado pelo mecanismo de mercado, porque não existiria "nenhum mecanismo de mercado que assegure um valor adequado para $w$ [propensão a investir]" (DELFIM NETTO, 1965, p. 59).

Como assume-se que a quantidade de investimento na indústria de bens de consumo - a que aumenta o consumo da população - depende do tamanho do investimento total na economia, e este, cresce à medida que cresce o investimento na indústria de bens de capital, então a economia deveria investir mais na indústria de capital do que se esperaria caso analisasse apenas o consumo no curto prazo. Novamente, esse fato acarretaria em certos problemas ao desenvolvimento caso este fosse deixado para ser resolvido pelo mercado:

$\mathrm{O}$ aspecto mais interessante do modelo é justamente o "paradoxo de Mahalanobis" (Bronfenbrenner, 1956), pois que, a longo prazo, a taxa de desenvolvimento depende apenas do comportamento do setor da indústria de bens de produção. Toda dificuldade decorre, evidentemente, da circunstância de que o critério de investir nos setores de mais elevado coeficiente produto/capital tem sua racionalidade restrita ao curto prazo (DELFIM NETTO, 1965, p. 59).

Delfim ainda chama a atenção de que o esforço de poupança (ou o quanto será destinado à indústria de bens de capital) não só depende da produtividade deste setor, como também da produtividade do setor de bens de consumo, pois uma maior produtividade nesse setor permite um maior esforço de poupança, em outras palavras, pode-se dizer que a maior produção de "bens de salário" permitiria que menor parte da renda fosse gasta nesses bens e mais sobraria para ser poupada. Assim, o paradoxo seria que a uma "racionalidade restrita ao curto prazo" a sociedade tenderia a investir na indústria de bens de consumo, a qual tornaria o esforço de investimento mais ameno; contudo, o crescimento do sistema depende - basicamente - do investimento na indústria de bens de capital. Por isso, novamente, se se dependesse "do acaso"; "do desenvolvimento natural da economia"; "do laisser-faire" o desenvolvimento dificilmente aconteceria: seria necessária uma “compressão inicial do consumo” (DELFIM NETTO, 1965, p. 67) e algum poder de coerção que fizesse os empresários investirem, pois, "os empresários, diante de um processo desta natureza, teriam de realizar investimento em função de uma elevação da procura no futuro, hipótese dificilmente realizável” (DELFIM NETTO, 1965, p. 67). A compressão do consumo é o outro lado da moeda de coação a obrigar uma maior parte da renda dos industriais ser dispendida em investimento, e não, em consumo. Uma sem a 
outra não faz sentido. Entender somente a compressão do consumo, ou a coação ao aumento do investimento é "fechar os olhos" para o todo da compreensão.

Aqui, podemos entender, implicitamente, como teria se dado a inflação do período - em especial do JK - ao dizer que ela é inerente ao desenvolvimento, caso não haja uma supressão inicial do consumo (frisando que em níveis absolutos ele continue igual) em relação à parcela do produto. Não somente os consumidores se organizariam - para garantirem uma parcela maior da renda - também os industriais também o fariam; "nessas circunstâncias, a inflação começaria a auto-alimentar-se e a adquirir aceleração" (DELFIM NETTO, 1965, p. 68), a "briga" que seria causada pelo desenvolvimento pela maior "fatia" do produto pelas diferentes "classes sociais". Isso somente não ocorreria se estas “estivessem sob coação política” (DELFIM NETTO, 1965, p. 68)

Aqui, explicita-se a necessidade - para Delfim - de um "pacto social" para que o desenvolvimento aconteça, um pacto mesmo que à força, para um maior bem à "coletividade". Semelhante seria a uma "armadilha de Nash" na qual os integrantes buscando o melhor para si, e sem possibilidade de saber a ação dos outros 'jogadores' acabam caindo numa posição pior do que o sistema é capaz de possibilitar. Aqui também, seria, então, necessário, que a parcela do consumo pelo tamanho do produto diminuísse, e mesmo assim, o investimento teria que aumentar (mantendo, a "renda líquida" do empresário, também igual em valores absolutos), mesmo sem haver muitos incentivos para tal, dado que o mercado não aumentaria necessariamente (porque o consumo está comprimido $)^{139}$. Observando a dificuldade que seria suprimir o consumo nos primeiros períodos, Delfim tenta chegar a um meio termo, ao analisar a "taxa ótima de desenvolvimento" na qual o consumo, investimento e desenvolvimento do produto econômico sejam balanceados para que nenhum sobrecarregasse muito a população. Caberia, então, aos planejadores (o governo) controlar a inflação ao impedir a "disputa pelo rendimento"; "As dificuldades aumentam quando consideramos que na ausência de um controle estrito da distribuição do rendimento, a realização de um processo da natureza anterior deveria causar uma tremenda variação dos preços" (DELFIM NETTO, 1965, p. 85, grifos meus). Em outras palavras, caso não houvesse ainda mais controle sobre a economia, o processo poderia acarretar em uma grande elevação de

\footnotetext{
${ }^{139}$ Diz Delfim (1965, p. 83): “A análise do processo mostra que ele dificilmente poderia realizar-se dentro de um sistema de economia de mercado, sem um planejamento adequado, porque dificilmente existiriam incentivos a investir suficientemente fortes para induzir os empresário a realizá-los, particularmente no primeiro período, quando o consumo cresce lentamente".
} 
preços. Diagnóstico esse que parece explicitar a percepção que Delfim demonstra em seus artigos durante os anos JK.

Por outro lado, ao discutir um modelo a 4 setores - em contraste com os modelos a 2 setores (sejam os setores "indústria e campo" ou, "indústria de bens de consumo e de bens de capital) - para trazer o problema do balanço de pagamentos no desenvolvimento econômico. Neste modelo, existiriam 4 setores, o de bens de capital, de bens de consumo, bens intermediários e "bens agrícolas". A novidade desse modelo é que o desenvolvimento deveria estar restrito à produção do setor de bens intermediários ou a capacidade da economia em importar estes em complemento. Dessa maneira, tornar-seia endógeno o défice no balanço de pagamentos ao se importar aquilo que não é produzido internamente. Além disso, o consumo total do sistema deveria, também, ser igual ou menor a produção de bens de consumo. Isso condicionaria que, para se acelerar o desenvolvimento, seria necessário que a quantidade de recursos da economia (em valor absoluto) destinado à produção de máquinas e ferramentas aumentasse cada ano, o que, pela segunda restrição, poderia entrar em choque com o consumo, causando inflação em "uma economia de mercado" ou racionamento, "numa economia centralizada" (DELFIM NETTO, 1965, p. 95). Delfim comenta que em quase todos os modelos de desenvolvimento não levariam em conta essa restrição, pois seria possível a transferência de mão de obra da agricultura para outros setores sem, contudo, diminuir a produção do meio rural. Diz apenas que essa hipótese só é explicitada no modelo de Lewis (1954). Além deste, podemos citar outros, tais como Rosenstein-Rodan (1957), Leibenstein (1957 e 1958), Georgescu-Roegen (1964). Podemos ver, como diz Delfim, que - num país subdesenvolvido - ter-se-ia uma pressão adicional ao desenvolvimento, pois os consumos já “estão muito próximos do mínimo de subsistência” (DELFIM NETTO, 1965, p. 94), o que tornaria difícil aumentar a quantidade de recursos da economia destinada ao setor de produção de bens de capital; somente com uma hipótese como a do modelos de Lewis (e dos outros acima citados) é que se poderia aceitar transferências de mão de obra do setor agrícola para outros setores sem causar uma escassez de oferta de produtos daquele setor para o resto da economia. Esse "gargalo" tornaria muito mais complexo o desenvolvimento do que aqueles modelos suporiam, levando a um processo inflacionário (ou escassez no "socialismo"). 
Delfim apresenta, como fechamento de sua discussão sobre planejamento e desenvolvimento econômico por meio de $\operatorname{modelos}^{140}$, o mais relevante ao debate. Não só por representar um modelo mais completo, que incluiria todos os anteriores, mas, ressaltadamente, por dialogar diretamente com um artigo de Celso Furtado, escrito em 1958, intitulado "El Desequilibrio Externo em Las Economias Subdesarolladas"141, no qual este mostra que haveria necessariamente desequilíbrio externo no desenvolvimento de uma economia subdesenvolvida.

Delfim, portanto, para conseguir dialogar com o artigo de Furtado, traz à discussão um modelo que também internaliza o défice no balanço de pagamentos, para provar seu ponto de que "não existe incompatibilidade fundamental entre o desenvolvimento acelerado, a estabilidade monetária e o equilíbrio do balanço de pagamentos" (DELFIM NETTO, 1965, p. 97). O modelo trazido por Delfim se baseia em 7 hipóteses fundamentais: i) a relação produto/capital é variável e aumenta com o desenvolvimento ${ }^{142}$; ii) A taxa de investimento é variável (desejando-se aumentá-la progressivamente com o passar do tempo); iii) Coeficientes de importação associados ao consumo e ao investimento são variáveis. "Dessa forma, é quase certo que o aumento da taxa de investimento implicará numa redução dos coeficientes de importação, dentro de um prazo variável com a maturação do investimento" (DELFIM NETTO, 1965, p. 98); iv) Economia dual: setor mercado interno, setor mercado externo; iv.1) Maior produtividade no setor externo, onde a formação de capital pode ser realizada internamente, i.e., sem importação; iv.2) Setor exportador ajusta sua capacidade produtiva instantaneamente de acordo com a procura ${ }^{143}$. iv.2.1) O investimento no setor de exportação não depende da produção, somente da expectativa de exportação do tempo seguinte; v) $\mathrm{O}$ consumo, por depender dos coeficientes de importação e da 'propensão a investir', sai por resíduo, não dependendo

\footnotetext{
${ }^{140} \mathrm{O}$ quais abordaram, sucintamente; i) do problema de transferência de mão de obra para o setor industrial - e a pressão inflacionária decorrente disso -; ii) do trade-off entre consumo e investimento - e a possível espiral inflacionária em decorrência -; iii) da limitação de produção interna para sustentar o desenvolvimento - ou o possível défice no balanço de pagamentos em decorrência.

${ }^{141} \mathrm{O}$ mesmo artigo de Furtado foi publicado em 3 diferentes línguas. Em inglês, em espanhol e em italiano no mesmo ano, 1958. Delfim se refere ao artigo em língua inglesa: "The external disequilibrium of the underdeveloped economies". The Indian Journal of Economics, India, v.38, n.151, 1958. Os outros dois são: Il disequilibrio esterno nelle economie sottosviluppate. Rivista di Politica Economica, Roma, v.47, n.5, p. 456-461, 1958. / El desequilibrio externo en las economías subdesarrolladas. El Trimestre Económico, México, v.25, n.98, 1958.

${ }^{142}$ Para Delfim a Cepal suporia essa relação fixa, mas no "planejamento de algumas economias socialistas", como diz Delfim, estaria se levando isso em conta. Em especial Hovart(1960) o teria feito.

${ }^{143}$ Essa hipótese já é diferente daquela descrita no capítulo dois dessa dissertação, no tópico sobre comércio exterior, no qual a grande diferença é que o setor exportador brasileiro teria uma demora no reajuste da oferta, por se tratar de produtos agrícolas.
} 
diretamente da produção. Assim, nesse modelo há inflação; vi) não há restrição do balanço de pagamento, podendo surgir desequilíbrios na balança; vii) não haveria restrições de mão de obra (ou seja, supõe-na com produtividade marginal nula em ambos setores $)^{144}$. Tudo indica que esse modelo que Delfim descreve é uma mistura de vários modelos, com uma abordagem original:

Comparando o crescimento do capital neste sistema com os anteriores, verificamos que a possibilidade de modificar a taxa de acumulação e a relação produto/capital permitem obter um desenvolvimento acelerado que reproduz características de modelos de desenvolvimento mais eficientes do que os do tipo Harrod-Domar ${ }^{145}$. Resta estudar o comportamento do consumo e das importações em tal sistema, para verificar o problema da estabilidade monetária e do equilíbrio do balanço de pagamentos (DELFIM NETTO, 1965, 104).

Assim, o consumo dependeria da produção para o mercado interno e para o mercado externo. "O consumo passa a ser uma função linear da produção interna para consumo interno e da produção interna para exportação" (DELFIM NETTO, 1965, p. 105, grifos no original), resultando que as tentativas de "aceleração do desenvolvimento são frequentemente acompanhadas por déficits no balanço de pagamentos" (DELFIM NETTO, 1965, 107). Interessante que, nesse modelo, nota-se que o carro-chefe do crescimento da economia depende das magnitudes do crescimento das exportações e da quantidade de novo capital criado no setor interno. Se este último for maior que o crescimento das exportações, aquele será o condutor do crescimento. Todavia, como a necessidade de crescimento das exportações é dado pelo próprio processo de desenvolvimento (para financiar o défice criado de maneira exógena) a própria estrutura da economia definiria qual seria o setor condutor do crescimento, porque seria a própria estrutura do sistema que definiria a necessidade de importação para manter o crescimento do sistema. Isso nos remete à definição de Delfim ao trazer o conceito de "industrialização orgânica" discutida no segundo capítulo dessa dissertação; se o condutor da economia

\footnotetext{
${ }^{144}$ Diz Delfim sobre esse ponto: "É claro que, neste caso, o salário não é determinado pela produtividade marginal do trabalho. Para tornar possível a determinação da taxa de salário seria preciso introduzir um setor típico de subsistência do modelo, que concentraria em seu bojo todo o excedente de população e que liberaria mão de obra (sem diminuir sua produção) na medida em que os demais setores estabelecessem uma taxa de salário ligeiramente superior à sua produtividade média. Como nada se ganharia de essencial com a introdução do setor III, deixamos de fazê-lo" (DELFIM NETTO, 1965, p. 101).

145 O modelor de "Harrod-Domar" ficou bastante famoso por descrever uma situação de crescimento econômico no qual o dinamismo deste era dado pela dupla função do investimento: produziria a demanda agregada e o aumento da oferta. Desse fato, decorreria que o investimento precisaria sempre crescer (não bastaria ser positivo) para garantir demanda para a oferta nova criada (com a aceleração do investimento [ou, em termos matemáticos, a segunda derivada positiva]). Ademais, não existe setor externo ou possibilidade de exportação neste modelo.
} 
ainda fosse o setor externo, a industrialização continuaria não sendo orgânica, como definido por Delfim.

Mesmo assim, independentemente de qual setor seria o condutor do crescimento, Delfim conclui que caso não se aumentem as exportações por período, seria impossível o país desenvolver sem desequilíbrio no balanço de pagamentos. “(...)por melhor que seja a técnica do planejamento, não existe possibilidade de evitar o desequilíbrio do balanço de pagamentos, a não ser sacrificando a taxa de expansão do produto total" (DELFIM NETTO, p. 109).

Se se coteja esse argumento com o artigo de Furtado com o qual Delfim explicitamente diz dialogar para criar seu modelo, podem-se observar resultados interessantes. Nesse artigo, Furtado concorda com Delfim que o desequilíbrio do balanço de pagamentos é fruto do próprio desenvolvimento, sendo que este seria maior com desequilíbrio no balanço de pagamentos:

La tasa de crecimiento que puede alcanzar espontáneamente una economía subdesarrollada en condiciones de estabilidad de la balanza de pagos (...), es inferior a la tasa de crecimiento que puede lograr una economía desarrollada en condiciones idénticas (FURTADO, 1958, p. 232)

O aumento do ritmo de desenvolvimento supõe necessariamente "un aumento mas que proporcional de la demanda de importaciones." (FURTADO, 1958, p. 235). Isso aconteceria porque, nos países subdesenvolvidos, a propensão média a importar do setor "inversionista" é maior do que do setor consumidor. Assim, de nada adiantaria a solução “ortodoxa", pois o problema seria inerente ao desenvolvimento:

De acuerdo con las reglas de este sistema, todo intento de fomento del crecimiento tendrá que provocar un aumento relativo de precios de los bienes de capital, una reducción de la eficiencia marginal del capital y una contracción de la inversión a niveles compatibles con la capacidad para importar. Así pues, el mecanismo de cambios fluctuantes se traducirá en la frustración del desarrollo económico. Resumiendo, podemos decir que la relación entre la tasa de crecimiento que un país subdesarrollado puede alcanzar espontáneamente y la tasa de crecimiento de su capacidad para importar es menor que la unidad (FURTADO, 1958, p. 238)

Única conclusão possível, então, para a aceleração do desenvolvimento é:

Por tanto, no es sorprendente que aquella política que intenta fomentar el crecimiento económico, implique un despilfarro de recursos atribuible a la capacidad productiva ociosa, con la consiguiente presión sobre la balanza de pagos (FURTADO, 1958, p. 239) 
Como os países puderam evitar esse problema: "Para evitar semejante presión, aquellos países habrían necesitado, al intentar intensificar el desarrollo, de alguna guía para la asignación de su creciente inversión, que en ningún caso habría podido esperarse de su rudimentario sistema de precios" (FURTADO, 1958, p. 239). Furtado faz um diagnóstico - de que com o processo de desenvolvimento o aperto no balanço de pagamentos piora - e não o resolve. Apenas diz que o câmbio livre não permitiria o desenvolvimento, e por isso, precisar-se-ia de "alguna guia" para designar onde se investir. Furtado dá a entender, por esse artigo, que o país deveria se desenvolver à revelia da restrição externa. Só que, para Delfim, "alguna guia" para o investimento, por melhor que fosse essa "guia" não resolveria o problema da restrição externa. "Neste exemplo, o balanço de pagamentos só não teria défices se contasse com uma expansão das exportações de $5 \%$ ao ano. Sem o aumento de exportação, seria impossível o desenvolvimento, por melhor que fosse o planejamento" (DELFIM NETTO, 1965, p. 117).

Conclusão essa, a qual se encontra em sintonia com a de Furtado. Ambos postulam que o desenvolvimento leva a um aumento da pressão sobre a restrição externa do país, assim como, que o desenvolvimento necessita de um planejamento para acontecer ${ }^{146}$. Cotejemos, agora, os exemplos numéricos que os dois autores utilizam em seus modelos para explicitarmos esse ponto.

\section{Diz Furtado:}

El departamento A toma solamente el $20 \%$ de la fuerza de trabajo; pero su productividad media es cinco veces mayor que la de B. Por consiguiente, contribuye con $55 \%$ del producto e ingresos totales. La propensión media a importar en A es 0.4 y en B, 0.1. Por tanto, para la economía en su conjunto, la propensión media a importar es de 0.27. La estructura del gasto total durante un periodo dado de tiempo, sería como sigue:

\footnotetext{
146 Tavares (1964) é também dessa opinião de que os estrangulamentos externos - a partir de 1930 - têm sua causa final por uma dinâmica interna. Soares (1981, p. 125-126), ao analisar Tavares (1964), diz: "Dada uma restrição externa, que induziu a uma onda de investimentos substituidores, o novo estrangulamento externo, que vai gerar uma nova onda substituidora, é o resultado de dois motivos. Um deles é a precariedade da nossa base exportadores. Uma precariedade que decorre do fato desse modelo ser um modelo de desenvolvimento parcial (modifica apenas a estrutura industrial) e fechado (o setor dinâmico está voltado para o mercado interno), o que faz com que a nossa pauta de exportações dependa dos produtos primários (cujo dinamismo do mercado internacional é baixo)".
} 


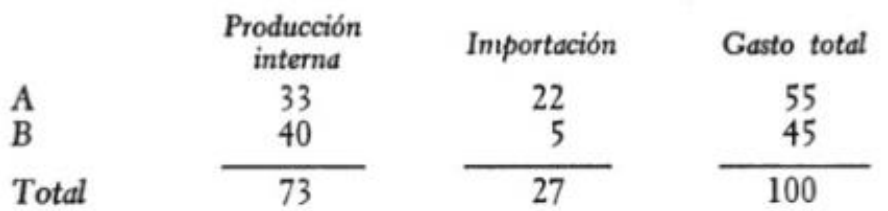

Supongamos ahora que la inversión neta se concentra en A y que, después de un periodo dado de crecimiento, la fuerza de trabajo de B a A. Debido a la diferente productividad de los dos departamentos, esta transferencia de fuerza de trabajo implicaría un aumento de $22 \%$ en la producción total. Si suponemos que subsisten las propensiones medias a importar del período anterior en los dos departamentos, la estructura del gasto total, al final de la etapa de crecimiento sería como sigue:

\begin{tabular}{|c|c|c|c|}
\hline & $\begin{array}{l}\text { Producción } \\
\text { interna }\end{array}$ & Importación & Gasto total \\
\hline A & 50 & 33 & 83 \\
\hline B & 35 & 4 & 39 \\
\hline Total & 85 & 37 & 122 \\
\hline
\end{tabular}

Las importaciones aumentarian $37 \%$, pero el gasto total se expandiria solo $22 \%$. La propension media a importar habria cambiado de 0.27 a 0.30" (FURTADO, 1958, p. 234-235, grifos meus).

Agora, Furtado, entende que qualquer processo de industrialização por substituições de importações exigiria, necessariamente, uma maior pressão sobre o balanço de pagamentos. É notável como os argumentos de Delfim são semelhantes àqueles de Furtado no artigo citado:

Fica claro, então, que a pressão maior do balanço de pagamentos decorre da aceleração da taxa de investimento, pois que a importação de bens de consumo diminui de 17,0 para 9,8, liberando, assim, 7,2, enquanto que as importações de bens de investimento se elevam de 10,5 para 30,0 aumentando a procura em 19,5. É evidente, agora, que nem mesmo no caso em que as importações para o consumo fossem reduzidas a 0 restabelecer-se-ia o equilíbrio do balanço de pagamentos (DELFIM NETTO, 1965, p. 120)

Porém, ao contrário de Furtado, Delfim propõe uma saída para esse problema do balanço de pagamentos: o aumento e diversificação das exportações, as quais deveriam abarcar não somente produtos agrários. Furtado parece que já se encaminha para uma resignação do desenvolvimento impossível, enquanto Delfim é extremamente otimista, acreditando que o desenvolvimento poderia acontecer (onde fosse), dependendo apenas da vontade 
daqueles envolvidos; não havendo nenhuma espécie de "fatalismo" quanto ao desenvolvimento de economias subdesenvolvidas. Seria necessário, contudo, sacrifícios grandes de toda sorte. Parte da população não poderia aumentar o consumo conforme o aumento da renda, e, outra parte, deveria destinar o aumento de parte de sua renda em investimento (ou seja, também diminuição de seu consumo em proporções da renda) em capacidade produtiva. Das duas respostas aqui apresentadas ao desenvolvimento, a de Delfim é mais amarga, sem dúvida. Contudo, é uma que responde às problemáticas da pauta do dia, e, delas não escapa.

Nessa sintonia Delfim, em 1966, escreve um artigo, em co-autoria com Nathaniel H. Leff, discutindo exatamente o problema das substituições de importações e o desequilíbrio no balanço de pagamentos no Brasil. Discorrem sobre o programa de Industrialização por Substituições de Importações (ISI). O modelo deles mostra o Brasil pós-guerra, e chegam a algumas conclusões sobre o processo. Nelas, é mostrado que essa industrialização (ISI) aumenta a renda, todavia não diminui o défice do balanço de pagamentos, que, pelo contrário, tende a aumentar, como resultado do aumento da renda. Pois o aumento das importações, estimulados pelo aumento de renda, superam os efeitos de diminuir as importações. A ISI pode funcionar como o setor líder de um país subdesenvolvido, caso o esforço devotado à substituição de importação seja grande o suficiente (DELFIM NETTO; LEFF, 1966, p. 222-223). Todo o artigo parece estar em completa sintonia com aquele de Furtado discutido aqui, e, ainda mais, com o diagnóstico feito por ele. Inclusive, com a última conclusão de Delfim e Leff de que as remessas de lucro são apenas uma pequena parte do défice. $\mathrm{O}$ grande problema localiza-se no efeito da criação de renda. Sendo assim, ambos concordariam que o défice é um problema estrutural do desenvolvimento. Explicitamente, Delfim e seu coautor dizem que a contribuição da remessa de lucros ao exterior para o balanço de pagamentos é apenas marginal, não gerando o problema em si; quando muito, o agravaria. Furtado não o diz, mas fica implícito quando afirma que todo o problema é da forma como o desenvolvimento ocorre com o aumento da renda no setor industrial voltado para o mercado interno.

Delfim vai mais além, afirmando, no artigo, que o Brasil teria um coeficiente de importações baixo, e, portanto, diminuí-lo não deveria ser a meta brasileira. Aliás, afirma que a pauta de importação acaba dependendo de uma menor variedade de produtos para importação, mas cada vez mais produtos cuja "elasticidade de substituição" ao consumo 
é muito baixa, como por exemplo, o petróleo e seus derivados ${ }^{147}$. Em outras palavras, que a pauta de importação fica mais "rígida". Novamente, a desvalorização do "câmbiocusto", levada à cabo pelo governo Jânio Quadros, não faria sentido algum a Delfim, esta, refletir-se-ia apenas em inflação.

Esta análise da restrição externa, e do processo de Industrialização por Substituições de Importações lembra muito o argumento de Conceição Tavares (1964), quando esta diz que o processo de industrialização por substituição de importações aumentaria o défice na balança de pagamentos, e as importações tornar-se-iam mais rígidas e se aumentaria, portanto, a dependência do setor externo ${ }^{148}$.

Delfim continua nessa linha, ao mostrar que o problema não só é estrutural, como é "muito estrutural”. Por ser um país em desenvolvimento e sem abundância de divisas estrangeiras, a importação não é definida como em outros países (onde é determinada pelo nível de renda, preços domésticos e estrangeiros relativos, e a taxa de câmbio). O coeficiente de importação no Brasil é limitado por dois motivos. O teto das importações é limitado pela oferta inelástica de divisas estrangeiras conseguidas pelas exportações tradicionais. $\mathrm{O}$ piso, pelo motivo de que ao congelar certas importações, diminui o crescimento da renda (Y). Mesmo no caso em que se tentasse resolver o problema com investimento externo, e esse investimento fosse extremamente produtivo, gerando ganhos de economia de escala, o problema da balança de pagamentos não seria solucionado. A única solução seria, ou aumento das exportações ${ }^{149}$, ou recorrer a "public capital flows", pois privados não adiantariam.

Dessa forma podemos notar que Delfim sempre foi crítico ao processo de ISI no Brasil como forma de resolver o problema do balanço de pagamentos. Algo que se apresenta em sintonia com alguns dos economistas brasileiros da Cepal aqui mostrados, Furtado (1958) e Tavares (1964). Ambos também se apercebiam dessa incapacidade de resolução da

\footnotetext{
${ }^{147}$ Dizem no artigo: "As more and more products were taken off the import list, the remaining imports were goods of low elasticity of substitution in consumption, for which the elasticity of substitution as between imports and potential domestic supply was also very low" (DELFIM NETTO; LEFF, 1966, p. 226).

148"Dadas las limitaciones de la capacidad para importar, la disminución relativa de las importaciones de bienes finales terminaría por transformarse en una disminución absoluta; la gama de importaciones se haría cada vez más rígida; las importaciones de bienes de capital, que son simultáneamente el grupo de mayor importancia entre los bienes finales, y el más flexible, se verían comprimidas. Esto no sólo frenaría el proceso de desarrollo, sino que aumentaría la vulnerabilidad de la economía frente al sector externo, ya que el mantenimiento de la propia actividad industrial quedaría en situación de dependencia estratégica de unas importaciones voluminosas de materias primas" (TAVARES, 1964, pp. 26-27).

${ }^{149}$ Delfim cita o caso da Austrália que teria conseguido manter exportações em níveis tais, que financiaram o desenvolvimento (DELFIM NETTO; LEFF, 1966, p. 230).
} 
restrição externa por esse problema. E esta era a maior dificuldade para o desenvolvimento brasileiro para os autores. Delfim, em especial, salienta-a sempre. Somado à ideia dele de que somente a industrialização poderia permitir o desenvolvimento (Ou ainda melhor, desenvolver-se era sinônimo de industrializar-se. Todavia, esta não poderia ignorar os problemas práticos decorrentes), dever-se-ia, portanto, atuar no sentido de diminuir custos da produção interna, e de elevar a capacidade de importar brasileira, o que, em última instância era o maior custo brasileiro. E, caso não o fizesse, não se conseguiria manter a indústria. Ainda mais, o aumento da produtividade da indústria, deveria vir acompanhado, necessariamente, de um aumento de produtividade agrícola. Pois a necessidade de comer (mesmo que os gastos com bens "básicos" tendem a reduzir-se como proporção da renda, à medida que esta aumenta, chamada de Lei de Engels, e muito comentada por Delfim) persistiria, independentemente da urbanização ou não. Ainda mais, com a especialização das profissões (o que ocorre com a urbanização da força de trabalho) há cada vez mais a necessidade de se recorrer ao mercado para a aquisição de bens essenciais à continuidade da vida, e, portanto, de a mão de obra poder continuar trabalhando. Esses bens essenciais (boa parte importada, ou que dependiam de insumos importados para a sua fabricação) refletiriam no custo do trabalhador.

\subsection{O papel da agricultura no desenvolvimento econômico brasileiro}

A discussão sobre o custo do trabalho (mesmo que apresentada de diversas formas) começou a ser tema decisivo, também, no primeiro lustro da década de 1960. Como visto, o Plano Trienal propunha a reforma agrária não só para se aumentar o mercado interno brasileiro, mas como forma de se poder aumentar a produção de alimentos para o país. Arguia-se que a estrutura atrasada da agricultura brasileira não se encontrava adequada para a produção de mercado, de tal monta, que ela não responderia às mudanças de preços. O PAEG, posteriormente, como será visto, também propôs a necessidade de reforma agrária para a continuidade do desenvolvimento no Brasil. Delfim discorda desses dois planos, porque não acreditava necessária a reforma agrária no país. Todavia, ele diz que se realmente a estrutura em algumas áreas no Nordeste fossem atrasadas, a reforma agrária poderia ser implantada pontualmente em alguns locais; menos como forma de desenvolvimento, e mais, como forma de mudança da estrutura da propriedade. 


\subsubsection{Delfim contra o diagnóstico da necessidade de reforma agrária para o} desenvolvimento no Brasil

Para esse propósito é importante discutir sete textos de Delfim dedicados ao assunto da relação da questão agrária e o desenvolvimento escritos durante a primeira metade da década de 1960. Seis destes foram reunidos em um volume publicados pela própria Faculdade de Economia da USP, com o objetivo de servir de material de leitura ao curso de "Economia Brasileira" lecionado naquela faculdade ${ }^{150}$. O outro, uma publicação “Anpes ${ }^{151}$ ", instituição que será discutida mais à frente nesse capítulo.

A falta de trabalhos (pelo menos para Delfim) que se baseassem no empirismo para a análise da agricultura no Brasil é um dos pontos fundamentais para o autor. As teses sobre agricultura no Brasil seriam feitas por puro "achismos", sem conhecimento da realidade brasileira. Nesse sentido, Delfim comenta um trabalho sobre a agricultura paulista, feito pelo engenheiro Salomão Schattan em 1961. Elogia a metodologia do trabalho por esse ter se debruçado em um estudo das propriedades e da realidade que as circunscreveriam, trabalho tido por Delfim como o "mais objetivo já publicado sobre a estrutura agrária", pois, a maior parte dos problemas do setor agrícola estariam a ser "resolvidos na base de puros palpites" (DELFIM NETTO, s.d., p. 223).

A conclusão do engenheiro indica que as propriedades de tamanho médio/pequeno seriam as mais produtivas. Delfim critica essa conclusão, arguindo de duas maneiras; a primeira, questionando a falta dedados coletados por aquele engenheiro, dizendo que não seria possível chegar àquela conclusão sem "o conhecimento do uso da terra por estrato" (DELFIM NETTO, s.d., p. 227), somente assim seria possível estabelecer qualquer relação entre o rendimento e a produtividade na propriedade; a segunda crítica, seria com Delfim se utilizando dos mesmos dados daquele estudo. De acordo com Delfim, então, seriam aquelas entre 1000 a 2999 hectares que indicariam uma maior produtividade (mesmo que ele diga ser impossível afirmar isso decisivamente), ou, por outro lado, que seria "impossível concordar com a afirmação de que as propriedades com dimensão entre 30 e 90 hectares" seriam as melhores ajustadas à realidade brasileira (DELFIM NETTO, s.d., p. 233). Não obstante, a produtividade das propriedades não poderia ser simplesmente analisada da maneira que o estudo apresenta, pois, como diz Delfim, dentro

\footnotetext{
${ }^{150} \mathrm{E}$ tendo como docente principal o próprio Delfim Netto.

${ }^{151}$ Associação Nacional de Programação Econômica e Social. DELFIM NETTO, A. PASTORE, A. C. CARVALHO, E. P. Agricultura e desenvolvimento no Brasil. Estudo ANPES $n .^{\circ} 5$ (versão preliminar). São Paulo: ANPES, 1966.
} 
de uma mesma propriedade se teriam diferentes tipos de qualidade da terra/terreno. O que tornaria muito provável que em uma propriedade muito grande, utilizar-se-iam todas as qualidades de terra, diminuindo a produtividade aparente da propriedade (DELFIM NETTO, s.d., p. 98). Outro problema de análise dos dados seria a medição da produtividade por meios monetários, ao invés de físicos. Seriam dois tipos diferentes de medição, pois duas propriedades com as mesmas produtividades físicas, teriam produtividades monetárias aparentes diferentes, em depender da distância do "centro consumidor dos produtos e do centro fornecedor de fatores de produção" (DELFIM NETTO, s.d., p. 101).

Nessa toada, critica a interpretação à la "Lewis" sobre a agricultura brasileira. Essa crítica tem em especial duas vertentes: a primeira, reinterpretando os dados disponíveis como demonstrado a cima; e, a segunda, conceitual. Em relação a esta última, Delfim diz que seria necessário se entender a diferença entre a "produtividade marginal do trabalho" e a "produtividade marginal do trabalhador". O segundo conceito estaria relacionado com uma situação na qual se seria possível reorganizar uma estrutura produtiva, mesmo com a retirada de um trabalhador, e ainda obter o mesmo produto final. $\mathrm{O}$ primeiro conceito se refere a uma situação na qual o trabalhador não produz nada, "pois isso" equivaleria "a afirmar que a unidade de mão de obra retirada não tinha nenhuma tarefa dentro da propriedade". Assim, não se poderia dizer que o custo da retirada de uma mão de obra da unidade de subsistência não tenha custo nenhum. Só assim pareceria ser possível - para Delfim - explicar o porquê se muito se falaria, por um lado, em "desemprego disfarçado" e ao mesmo tempo, por outro, "os empresários agrícolas" persistirem "na afirmação de que o "fator limitante da produção de subsistência é a escassez de mão de obra"" (DELFIM NETTO, s.d., p. 107), pois as terras dedicadas à subsistência teriam uma produtividade mais baixa não permitindo que à taxa de salário vigente à época fosse rentável "explorar as terras inferiores". A única solução para o aumento da produção de bens de subsistência para Delfim seria o aumento da produtividade por homem, só possível com "um aumento substancial de sua mecanização". Caso contrário, as pressões inflacionárias só aumentariam. A mão de obra deveria ser liberada, e o principal gargalo era na colheita. Delfim sugere que se deva fazer estudos para a liberação de mão de obra nesse período, substituindo-a pela máquina. "É difícil imaginar, portanto, que se possa, a curto prazo, encontrar uma forma de superar o problema da "ponta" de demanda de mão 
de obra, a não ser reduzindo a quantidade de trabalho humano necessário para a colheita" (DELFIM NETTO, s.d., p. 188-189).

E essas pressões inflacionárias seriam um problema para o desenvolvimento industrial, e, portanto, de acordo com Delfim, para o próprio desenvolvimento econômico do país. Ao discutir novamente a agricultura paulista, parte do pressuposto macro que se é necessário o aumento da produtividade agrícola, em especial, para libertar o homem do campo e permitir-lhe trabalhar na cidade. Dever-se-ia pensar o sistema em conjunto, e não apenas em setores, porque a necessidade de "'fixar o homem à terra ${ }^{152}$," não corresponderia "às necessidades do desenvolvimento econômico do país” (DELFIM NETTO, s.d., p. 132)

Haveria problemas, sem dúvidas, quanto à produção agrícola de subsistência para a mão de obra. As terras de São Paulo teriam seus solos fatigados pela falta de tecnologia e conhecimento aplicados à cultura. Sentir-se-ia "o desperdício de recursos produzidos por uma agricultura itinerante, instalada em lugar da floresta virgem recém-queimada, sem nenhum cuidado conservacionista e quase sem a utilização de adubos" (DELFIM NETTO, s.d., p. 146-147). No passado, o uso de "técnicas de cultivo predatório" não havia prejudicado tanto a produção de alimentos - a ponto de se sentirem pressões tão fortes - pois ainda teria havido terras virgens para serem cultivadas. Contudo, esse quadro teria passado por uma inversão, até a "rápida ampliação da área plantada com café a partir de 1954, depois da geada (julho de 1953), que elevou violentamente os preços do produto" (DELFIM NETTO, s.d., p. 154-155) o qual o teria piorado de vez. Para a superação dessas "técnicas predatórias", o agricultor necessitaria financiamentos abaixo daqueles que estariam sendo disponíveis naquele momento, i.e., maior crédito à agricultura (DELFIM NETTO, s.d., p. 150-151)

Existiria, portanto, uma necessidade premente de melhora da produção agrícola para o melhor desenvolvimento econômico (como Delfim salientou durante todos os escritos aqui analisados). Ao se analisar a produção, Delfim percebe que há diferentes movimentos. A cana de açúcar, mandioca, batata, amendoim e o milho, estariam todos tendo suas produções aumentadas. Já o algodão, arroz e feijão estariam estagnados. A produtividade, por outro lado, viria aumentando em muitos produtos (não em todos, contudo), só que este ganho de produtividade não estaria sendo transferido para o produtor agrícola. Estes ganhos estariam sendo "transferidos para os demais setores da

\footnotetext{
${ }^{152}$ Como estipulado pelo "estatuto da terra" por exemplo.
} 
economia na forma de um crescimento menos rápido dos preços" (DELFIM NETTO, s.d., p. 173). Um problema do comércio que impediria essa transferência: o setor produtor agrícola funcionaria (“devido à multiplicidade de agentes") num regime próximo ao da livre concorrência (DELFIM NETTO, s.d., p. 110). Já a compra dos produtos seria feita por "uns poucos grandes comerciantes (e industriais)", permitindo-os "impor preços baixos à agricultura, pela simples razão de que constituem uma procura coalizada em presença de uma oferta atomizada" (DELFIM NETTO, s.d., p. 110). Assim, nem o consumidor e nem o produtor ganhariam com o aumento de produtividade, pois "a existência de formas oligopolísticas" garantiriam "a retenção interna da parcela mais substancial de tais transferências" (DELFIM NETTO, s.d. p. 111).

Mesmo que esse texto de Delfim tenha sido publicado originalmente em 1962, nota-se que Ignacio Rangel fez uma argumentação muito similar a essa no livro A Inflação Brasileira, lançado em 1963. Diz este:

Ao estudarem a inelasticidade da oferta de produtos agrícolas, os estruturalistas
tomaram a nuvem por Juno. Concretamente, o que há é que, em numerosos
casos, a agricultura não reage à elevação de preços ocorrida no nível do
consumidor final, por um aumento da produção. Ora, isso não significa
inelasticidade da oferta agrícola, mas, simplesmente, que a comercialização
dos produtos em causa é feita através de um oligopsônio-oligopólio, que
opera como se monopsônio-monopólio fosse, e que intercepta, no nível
intermediário, o incremento de preços pagos pelo consumidor final,
impedindo que este chege ao produtor. Trata-se, portanto, de uma
anomalia no mecanismo de formação de preços, e não da inelasticidade da
oferta agrícola. Ao contrário, para que esse mecanismo funcione, é necessário
que a oferta agrícola seja não somente elástica ao preço - entenda-se, ao preço
do produtor agrícola - mas muito elástica (RANGEL, [1963] 2012, p. 29,
grifos meus).

Outrossim, vale a pena destacar dois pontos quanto a questão Rangel-Delfim Netto. A primeira é que as semelhanças da interpretação entre os dois e seus diagnósticos em relação à agricultura brasileira foram destacadas por Soares (2014). Em segundo lugar, na Biblioteca Delfim Netto, localizada na Faculdade de Economia da Universidade de São Paulo (FEA/USP), pode ser encontrado o livro de Rangel lido e anotado pelo próprio Delfim. Esse livro fora parte das discussões dos seminários promovidos por Delfim na faculdade, e na biblioteca da FEA encontra-se o livro com os capítulos comentados à mão sobre quem seria o responsável pela leitura de qual parte do livro.

Quanto à transferência de recursos do setor agrário para o industrial, esta seria fundamental para financiar "setores mais dinâmicos" da economia, só não se podendo esquecer que esse fato deva ser entendido de forma especial, para que se dedique especial 
atenção à agricultura "nos programas de desenvolvimento, a fim de que ela possa continuar e expandir-se” (DELFIM NETTO, s.d., p. 112). A importância do equilíbrio entre os dois setores, agrário e industrial, é repetidamente reiterada para o desenvolvimento. A agricultura tem seu papel pois permitiria "a) liberação de mão de obra a ser utilizada no setor industrial sem diminuir a quantidade produzida de alimentos; b) criação de mercado para os produtos da indústria; c) expansão das exportações; e d) financiamento de parte da capitalização da economia" (DELFIM NETTO, s.d., p. 85). Já a indústria seria necessária pois sem ela o desenvolvimento entraria em estagnação, pois - valendo-se novamente da "Lei de Engels" - a demanda por produtos agrícolas cresceria menos do que proporcionalmente com o aumento da renda.

Chegamos assim, à conclusão de que a idéia de fazer o desenvolvimento econômico realizar-se por uma elevação da produtividade dentro do próprio setor agrícola equivale a alguém querer levantar-se pelo próprios cabelos (DELFIM NETTO, s.d., p. 271).

\subsubsection{O diagnóstico do PAEG sobre a agricultura e a necessidade de reforma agrária para o desenvolvimento econômico no Brasil}

A necessidade de reforma agrária, inclusive, era, também, o diagnóstico do PAEG (Programa de Ação Econômica do Governo) encabeçado pela dupla Octávio Bulhões e Roberto Campos. Este último escreve, ainda em 1960, na Revista de Ciências Econômicas, sobre a "tecnologia bastante primitiva" e da "relativa inelasticidade" do setor de produção de alimentos em países como o Brasil (especializados na exportação de matérias primas para a exportação), sobre seu "impacto, portanto, sobre os preços internos e sobre o custo de vida", e sobre este custo ser "difícil de combater com a tradicional arma de política monetária" (CAMPOS, 1960, p. 07-08 e 25). Pode-se perceber a continuidade desde diagnóstico ao se ler o programa de governo dele. O PAEG, que estabeleceu as "linhas gerais" da política econômica do Governo Castelo Branco, foi posto em operação em julho de 1964 (PAEG, Maio de 1965, p. 15). Neste programa havia, também, o diagnóstico de que a oferta de produtos agrícolas não reagia a preços, o que poderia comprometer toda "a expansão do conjunto" brasileiro:

No caso brasileiro, contudo, o sistema de incentivos criados para acelerar a industrialização não teve a acompanhá-lo decisões de política agrícola que limitassem o desnível das taxas setoriais de expansão a uma amplitude compatível com o crescimento harmônico da economia como um todo. (...) A expansão do setor ainda repousa, basicamente, numa agricultura itinerante, pouco sensível para responder aos 
estímulos da demanda criados pela industrialização e a consequente urbanização. Sob esse aspecto, a excessiva disparidade entre as taxas setoriais de crescimento configura um caso em que a agricultura emerge como setor retardatário, ameaçando comprometer a expansão de todo o conjunto (PAEG, Maio de 1965, p. 93, grifos meus).

E, ainda:

A evidência do atraso relativo da agricultura pode ser apresentada, numericamente, quando se considera a oferta de produtos alimentares. A persistir a tendência històricamente observada na produção agrícola orientada para o consumo interno, a demanda potencial de alimentos no Brasil, proveniente de um crescimento econômico regular de 3,4\% por habitante ao ano (taxa almejada), e de uma elasticidade média de demanda de 0,49, traduzir-se-á, anualmente, numa diferença de $\mathbf{5 \%}$ nos ritmos de expansão entre demanda e oferta agregadas, cujos efeitos cumulativos, no tempo, representarão uma pressão inflacionária de intensidade crescente (PAEG, Maio de 1965, p. 9394, grifos meus).

Nestes dois trechos duas posições a respeito do diagnóstico sobre a agricultura brasileira explicitam-se, a saber: o descompasso da resposta da oferta de produtos agrícolas com a demanda por estes; e o sentimento de que o desenvolvimento dos setores urbanos e da industrialização seriam atrasados pelo atraso sistêmico do setor agrícola, em especial, do setor produtor de alimentos. Há, ainda, um dos motivos principais a causa desses dois problemas:

(...) não há dúvida de que a distribuição emergente do Censo Agrícola sugere, de imediato, dois tipos de malformação na estrutura agrária: a grande propriedade, na qual o uso da terra como fator de produção é, em larga medida, desperdiçado, e a exploração demasiado pequena, incapaz de gerar economias de escala e permitir o uso da força motriz de certos implementos agrícolas (PAEG, Maio de 1965, p. 93-94, grifos nossos).

Desta forma, seria necessário averiguar quais as grandes propriedades que seriam pouco utilizadas para se realizar algum tipo de "drástica mudança da estrutura agrária de determinada região" (PAEG, Maio de 1965, p. 104, grifos nossos). Neste mesmo sentido, far-se-ia necessário:

A eliminação de elementos institucionais de monopólio constitui um argumento de natureza econômica em prol da modificação da estrutura fundiária. A existência de um monopólio institucional em certas áreas de latifúndio deriva do fato de que, pela falta de mobilidade geográfica da mão-de-obra rural (...) o proprietário da terra é, em verdade, um monopsonista com relação ao fator trabalho. Controlando mais o uso da terra do que propriamente o preço desta, o proprietário pode lançar mão do seu poder monopsônico para manter os salários em baixo nível e 
dessa forma, postergar mudanças tecnológicas que aumentem a relação capital/trabalho (EPEA, Maio de 1965, p. 105, grifos nossos).

O PAEG, contudo, não defende a "reforma agrária" geral. Faz uma breve apreciação de que a reforma agrária, em seu sentido tradicional ${ }^{153}$, não teria eficácia no Brasil. Chama, algumas vezes, de maneira um tanto demagoga, de "reorganização agrária". E, esta "reorganização agrária" seria feita, por meio de leis que foram aprovadas ainda em $1964^{154}$ :

O Poder Público, além de outras providências diretas ou indiretas que objetivam melhorar as condições rurais, utilizará para efeito de facultar o acesso à terra, os seguintes meios: tributação progressiva, desapropriação por interêsse social, colonização, arrecadação dos bens vagos, recebimento de terras por doação ou permuta e aquisição de terras por contratos de compra e venda (PAEG, Maio de 1965, p. 107 , grifos nossos).

Depois de se ter compreendido que a reforma agrária fazia parte do PAEG, não como medida puramente ad hoc, apenas "para inglês ver", algum instrumento demagógico para angariar apoio; mas pelo contrário, a reforma agrária era parte do raciocínio que diagnosticava a estrutura agrária no Brasil como atrasada, e não responsiva a preços, e que estava atrasando o desenvolvimento no Brasil. Desta forma, apesar de todas as palavras que tentam atenuar o projeto de reforma agrária no PAEG, ela é intrínseca ao diagnóstico, não podendo ser excluída, sem excluir completamente o diagnóstico em si ${ }^{155}$. Para insistirmos neste ponto, podemos observar, em outro livro lançado pelo Epea (dez. $1965)^{156}$ a ideia de que, para o PAEG, a reforma agrária solucionaria o descompasso entre o crescimento do setor urbano e o setor agrícola. E ainda, que a reforma agrária aumentaria o mercado interno consumidor:

A sensível diferença, outrossim, no ritmo de melhoria entre as condições de vida da população rural e urbana, estava impondo uma participação mais ativa do Poder Público, na remoção dos obstáculos ao progresso social dos assalariados rurais. (...) essa população sem terra tem estado praticamente alijada dos benefícios do nosso progresso (...). As contradições e desigualdade da estrutura agrária do Brasil se vinham agravando. (...) Comparativamente à situação verificada pelo Censo Agrícola de 1950, a posição relativa dos estabelecimentos de menos de 100 hectares permaneceu mais ou menos a mesma, enquanto aumentou o número das propriedades de menos de 10 hectares, revelando um desfavorável parcelamento dos estabelecimentos de dimensões médias. Essa distorção fundiária pode

\footnotetext{
${ }^{153}$ Que seria uma profunda mudança nas relações de propriedade da terra

${ }^{154}$ A lei da Reforma Agrária, n. ${ }^{\circ}$ 4.504/64.

${ }^{155}$ Conferir apêndice A deste trabalho para ver a síntese do programa de reforma agrária do PAEG.

${ }^{156}$ Escritório de pesquisa econômica aplicada, do ministério do planejamento e coordenação econômica
} 
ser ainda avaliada pelo aumento da percentagem de área ocupada pelos estabelecimentos rurais que se enquadram nos extremos das classes de área. Dados referentes ao último período intercensitário revelam, na verdade, um inconveniente aumento da ocupação de área tanto no que tange às propriedades maiores de 10.000 ha. como nos estabelecimentos com superfícies inferiores a 10 ha. Particularmente com relação a estes últimos, o aumento verificado - mais de $76 \%$ - identifica uma inconveniente anomalia estrutural que cabe à Reforma agrária corrigir." (EPEA, Dez. 1965, p. 124)

O diagnóstico continua:

Em contraposição, o crescimento da produção industrial gera a necessidade de alargamento do mercado consumidor, ou seja, a incorporação de novas áreas da população no consumo dos produtos industriais, que se pode obter peça elevação dos padrões econômicos da população rural. (...) c) [a Política de Desenvolvimento Rural deveria] criar, pela elevação do nível de vida no meio rural, um alargamento do mercado interno de consumo para absorver o crescimento da produção industrial do País; (...)" (EPEA, Dez. 1965, p. 125, grifos meus)

E, sempre tendo em mente a reforma agrária:

Impossível seria dissociar-se o baixo nível da produtividade agrícola do País do sistema de propriedade, posse e uso da terra. As relações de trabalho ligam-se, como não poderia deixar de ser, às condições em que êle exerce. Não havendo estímulos especiais para o aumento da produtividade, não recebendo o trabalhador agrário, via de regra, retribuição proporcional ao acréscimo da lucratividade, o desestímulo é consequência inevitável." (EPEA, Dez. 1965, p. 125126 , grifos meus).

Não podemos de deixar de perceber que o diagnóstico previa o atraso da forma de produção agrícola no Brasil. Não se utiliza de termos como "pré-capitalistas", ou “produção feudal", mas, dá-se a entender que o capitalismo não adentrara de forma suficiente em algumas regiões (de norte a sul no país), e nestas, a reforma agrária seria necessária. Ainda, por último, pode-se até ver um cunho igualitário/redistributivista na reforma agrária:

A Reforma Agrária visa a estabelecer um sistema de relações entre o homem, a propriedade rural e o uso da terra, capaz de promover a justiça social, o progresso e o bem-estar do trabalhador rural e o desenvolvimento econômico do País, com a gradual extinção do minifúndio e do latifúndio. (...) A desapropriação por interêssse social tem por fim: (...) promover a justa e adequada distribuição da propriedade (EPEA, Dez. 1965, p. 140-141, grifos meus)

Em consonância com essa perspectiva do PAEG, Dreifuss (1986) diz que a implementação da reforma agrária era "uma importante bandeira das elites orgânicas [capitalistas]" (DREIFUSS, 1986, p. 125). O caso do Brasil, na América Latina, da 
"direita" impor um projeto de "reforma agrária" não era - nem de longe - único. Pelo que o autor faz entender - mesmo que por motivos vários - esse projeto fazia parte da estratégia de dominação da “internacional capitalista ${ }^{157}$ ":

Uma importante bandeira das elites orgânicas foi também a da reforma agrária capitalista, cujos objetivos eram os mais variados, dependendo das intenções subjacentes, de ordem política ou econômica. Assim, a intenção podia ser a de aumentar a produtividade e os lucros, de abrir novos espaços à penetração do complexo agroindustrial de maquinário e fertilizantes, ou simplesmente a fixação do camponês na sua área, para esvaiar problemas decorrentes da migração aos centros urbanos. Mas o objetivo podia ser simplesmente o de minar as bases de apoio político e de sustentação econômica da direita tradicional, vista como empecilho para a modernização conservadora capitalista, ou o de conter as demandas da esquerda e sua capitalização dos anseios populares. $\mathrm{O}$ Ceres do Equador, o Ceas da Colômbia, o Ipes e o Ibad do Brasil, o Ipies do Chile, a AVI da Venezuela e muitos outros promoveram, em prol de seus projetos de reforma agrária, diversos congressos e seminários, com a divulgação de material relevante, e saíram em busca de apoio parlamentar às suas posições, com a criação de lobbies e outros mecanismos, contra as reformas propostas por patidos ou movimentos de esquerda (...) o Ipes brasileiro chegou a elaborar um "Estatuto da Terra" e promoveu a implantação do Instituto Brasileiro de Reforma Agrária, após o golpe de 1964 (DREIFUSS, 1986, p. 125-126).

Dessa forma, dificulta-se a dicotomia de posicionamento político ao classificar aqueles que eram a favor da reforma agrária e aqueles que se posicionariam contra ela na década de 1960 no Brasil. Sabidamente o PCB (por exemplo, Alberto Passos Guimarães (e.g. 1977) e Nelson Werneck Sodré (e.g. 1997)) eram a favor; todavia, Caio Prado Junior (e.g. 1978), importante quadro do pensamento comunista no Brasil e Ignácio Rangel (e.g. [1963] 2012 ${ }^{158}$ ) tido como pensador de esquerda, eram visivelmente contra as propostas de Reforma Agrária no Brasil ${ }^{159}$.

\subsubsection{Delfim contra a reforma agrária nos diagnósticos do Plano Trienal e PAEG}

Tendo-se entendido bem a perspectiva de Delfim sobre a agricultura, fica mais fácil de compreender sua crítica aos programas/planos econômicos desenvolvidos na primeira metade da década de 1960. Ao se tratar do Plano Trienal, Delfim concorda com o plano

\footnotetext{
157 Termos utilizados pelo próprio autor.

158 Não à toa o livro do Rangel foi lançado no mesmo ano que o Plano Trienal, pois com ele dialogava e combatia frontalmente o diagnóstico do Plano. Ele teria sido, de acordo com Bresser Pereira e Marcio Rego (1993, p. 101-102) convidado para ser ministro da Fazenda pelo então presidente João Goulart, recusa o convite e Celso Furtado (como ministro do Planejamento) põe em prática um plano econômico que ia frontalmente com a visão de Rangel sobre a economia.

${ }^{159}$ Para uma discussão mais detalhada sobre as diferentes perspectivas de reforma agrária no Brasil, c.f. Soares (1992)
} 
trienal em dois pontos fundamentais: i) de que seria necessário o aumento da industrialização para aumentar o desenvolvimento da agricultura;

De fato, sendo a demanda de produtos primários relativamente inelástica às flutuações da renda, é necessário que o ritmo de atividades do setor urbano, particularmente da Indústria - que constitui o centro dinâmico do processo de desenvolvimento - se eleva a taxas significativamente mais altas, para que a Agricultura logre nível satisfatório de expansão (PLANO TRIENAL, 1962, p. 126).

Diz Delfim:

Mas é extremamente duvidoso que se possa superar o impasse da falta de mercado por uma ampliação da demanda agrícola. Uma indústria de massa, exige uma sociedade de massa e não é razoável supor que tal processo possa realizar-se sem um intenso processo de urbanização (DELFIM NETTO, s.d., p.265-266)

E, ii) de que haveria mão de obra subutilizada na agricultura:

Os efeitos negativos de tão desigual distribuição de terras sobre o emprego de mão-de-obra rural assumem duas formas principais. A primeira consiste na excessiva concentração da mão-de-obra nas pequenas propriedades, pois as grandes, mantendo praticamente ociosas suas terras ou ocupando-as quase que só nominalmente através da pecuária extensiva, não oferecem oportunidade de ocupação à população ativa dos campos. A segunda forma que assumem os efeitos negativos da distribuição de terras sobre a ocupação rural é a aguda estacionalidade a que sujeita a mão-de-obra assalariada. Não dispondo de terras próprias e concentrando-se as oportunidade de emprego nas propriedade de menor tamnho $-60 \%$ do pessoal emprego, em 1950, o era em propriedade de menos de 50 hectares - as massas assalariadas são mantidas subutilizadas, pois só conseguem ocupação nas épocas da colheita. Considere-se, ademais, que a pecuária extensiva, típica da grande propriedade, não constitui fonte expressiva de emprego (PLANO TRIENAL, 1962, p. 143).

Delfim discorda que essa mão de obra devesse ficar na agricultura, sendo necessária sua liberação para os setores urbanos; e, discorda, também, de que o problema seria que os ganhos de produtividade da agricultura estariam sendo favoráveis ao setor rural, ficando mantidos pelos proprietários agrícolas, como afirmaria o Plano Trienal:

A distribuição fortemente regressiva da renda agrícola, ensejada pelas formas de exploração da propriedade a que dá margem a estrutura agrária defeituosa, não permite que os ganhos de produtividade, bem como a transferência de renda do setor urbano para o setor agrícola (...) atinja as massas rurais, pois que são absorvidas, na sua maior parte, pelo pagamento do aluguel de terras. Estes incrementos de renda, não se convertendo em fator de elevação dos padrões técnicos da Agricultura ou em instrumento de melhoria do bem-estar do trabalhador agrícola, tornam mais onerosa a industrialização (PLANO TRIENAL, p. 147). 
Assim, Delfim não concorda que os ganhos teriam sido retidos pela agricultura. Para ele, é exatamente o contrário que teria ocorrido: os ganhos estariam sendo retidos pelos setores comerciais, e não ficando com o produtor agrícola, e, por isso, seria o grande motivo que o reinvestimento na agricultura em ganhos de produtividades poderiam não estar acontecendo. O diagnóstico do Plano Trienal não seria novidade para Delfim, pois este afirma que raciocínios como este seriam frutos de uma análise "superficial da realidade" a qual encararia "a América Latina como um todo", e se teriam "generalizado diagnósticos talvez válidos para os casos que examinaram", mas que não corresponderia ao caso brasileiro (DELFIM NETTO, s.d., p. 01-02). Inclusive, ao se ler o livro de Delfim dedicado em exclusividade à análise da inflação brasileira (DELFIM NETTO et al., 1965); vê-se ele comentando sobre o estudo de Sunkel a respeito desta conclusão no Chile, admitindo a validade daquela análise lá $^{160}$. Mas essa argumentação não resistiria "ao teste da realidade, quando analisamos o caso brasileiro" (DELFIM NETTO et al., 1965, p. 51). Nesse sentido, Delfim compara o "custo de Alimentação" (custos que o consumidor final paga) com o "Preços no Atacado" (excluindo os preços do café que estariam congelados durante 1954-59). Dessa análise, nenhuma discrepância surge, com os dois caminhando em caminhos muito próximos. Depois testa - econometricamente a variação dos "meios de pagamento" com a variação dos "custos de alimentação", sugerindo que talvez existisse "uma defasagem de dois meses entre os aumentos dos

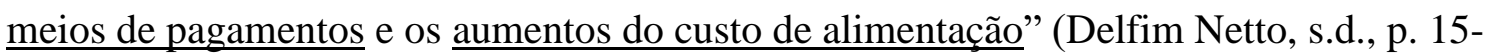
17, grifos no original). Os dados não permitiriam rejeitar a hipóteses de que " $1 \%$ do aumento de meios de pagamentos produz, com a defesagem conveniente, $1 \%$ de aumento do custo de vida" (DELFIM NETTO, s.d., p. 25). A conclusão é de que não existiria, portanto, nenhuma evidência "no nível global" de que a procura de alimentos cresceria mais depressa do que a oferta. Critica o plano Trienal por este afirmar que haveria evidências de - nas palavras do Plano - "elevação dos preços dos produtos mais forte que a dos preços industriais" e que haveria uma "relação de preços de intercâmbio crescentemente favorável à agricultura", afirmando que conteria um erro no cálculo do deflator implícito industrial ${ }^{161}$

\footnotetext{
160 "No entanto, não deixa de ter validade, entre outros o caso do Chile, onde o setor produtor de alimentos, conforme os dados de preços agrícolas parecem indicar, não se ajusta ao crescimento da demanda (veja-se, a respeito, "La inflación Chilena - Um enfoque Heterodoxo". Sunkel Osvaldo, in El Trimestre Econômico, Cidade do México, $\mathrm{n}^{\circ}$ 100, outubro/dezembro, 1958)" DELFIM NETTO et al. 1965, p. 51.

${ }^{161}$ Citações do Plano Trienal apud Delfim, s.d., p. 26 e p. 37.
} 
Mesmo que os preços dos produtos agrícolas (no nível do consumidor) tivessem subido mais do que os do produtos industriais, isto não significaria, necessariamente, uma transferência da renda para o setor agrícola (como está dito no Plano Triena). Os preços dos produtos de alimentação no nível do produtor tem subido menos do que no nível do consumidor, o que sugere que as margens de comercialização tem sido ampliadas (...) seria preciso executar uma verdadeira política agrária, capaz de tornar mais eficiente a comercialização e assegurar a remuneração dos produtores, para aumentar a oferta de produtos agrícolas (DELFIM NETTO, s.d., p. 38)

Assim, Delfim critica o PAEG e o Plano Trienal em seus diagnósticos à agricultura:

No governo João Goulart, a principal defesa da reforma agrária residia na necessidade de "modificar-se a estrutura arcaica da agricultura brasileira", de forma a melhorar o nível de produtividade do setor e permitir a liberação de mão de obra para ser utilizada na indústria ${ }^{162}$. No governo do Marechal Castelo Branco defende-se a reforma agrária porque é preciso conservar os homens no campo, uma vez que o setor industrial não tem dinamismo suficiente para absorver a mão de obra que é anualmente liberada (...) Diagnósticos tão antagônicos, realizados pelos mesmos técnicos com uma diferença de menos de seis meses não podem corresponder a um problema real e devem, portanto, refletir uma alta dose de confusão (DELFIM NETTO, s.d., p. 257258 , grifos meus).

Questiona três afirmações cruciais do PAEG. Em primeiro lugar, o Programa de Ação Econômica do Governo diagnosticaria que haveria uma diferença no crescimento agrícola e industrial. Para comprovar isso, o Programa afirma que em 1957/61 o setor agrícola se expandiu 5\% ao ano, e o industrial, 12\%. Para Delfim, essa conclusão (a partir dos próprios dados do PAEG) não faz sentido. $\mathrm{O}$ crescimento harmônico deveria se dar juntamente com as proporções da elasticidade renda de produtos agrícolas e de produtos industriais, e, não, linearmente como indicava o PAEG, pois, certamente, a elasticidade de produtos industriais seria maior do que 1, e a de produtos agrícolas (calculada por Delfim) seriam da ordem de 0,5. Desta forma, só haverá um maior crescimento da demanda do que da oferta de produtos agrícola - e consequente aumento de preços - se a oferta de longo prazo dos produtos agrícolas for inelástica aos preços reais. Essa, no fundo, é a premissa essencial. E, para Delfim, “ao tentar prová-la, entretanto, o Programa fica em situação ainda mais delicada do que o Plano Trienal quando fêz a mesma afirmação" (DELFIM NETTO, s.d., p. 284). Assim, por falta de provas, não se pode

\footnotetext{
${ }^{162}$ Fica um pouco estranha essa afirmação de Delfim que o Plano Trienal intencionava a liberação de mãode-obra para que fosse aplicada na indústria. Tudo indica, pelo contrário, que se tencionava liberar a mãode-obra para que fosse aplicada no próprio setor agrícola.
} 
afirmar algo desta magnitude. Concluindo que não se pode provar a afirmação número um.

Em segundo lugar, pelo diagnóstico do PAEG, a agricultura teria crescido apenas pelo deslocamento da fronteira agrícola, e não pela incorporação de novas tecnologias. Para chegar a essa conclusão, o programa apresenta uma série de preços de produtos agrícolas de mercado interno ao nível do produtor, e uma série de custo de alimentação na Guanabara. E, tendo-se um aumento maior dos preços ao consumidor final, do que dos preços dos produtores, isso apresentaria uma maior distância das frentes agrícolas. Este silogismo mostrar-se-ia não justificável - pelo menos - por dois motivos: $1^{\circ}$ Quase a grande maioria dos produtos de consumo agrícola teria passado a ser - a partir de quase uma revolução alimentícia - fornecida com algum grau industrial. $\mathbf{2}^{\circ} \mathrm{Mesmo}$ assim, os dados fornecidos pelo PAEG precisariam ser melhor interpretados ("O mais grave, entretanto, é que os dados fornecidos, apesar das aparências não provam nada" (DELFIM NETTO, s.d. p. 285)). A relação de preços tem aumentado juntamente, a não ser em três anos especiais $(1954,1959,1962)$. Posteriormente, Delfim questiona o segundo ponto de coerência do próprio programa: o fato de se deveria aumentar a produtividade no campo com maquinário, se a idéia era de "manter o homem na terra". Se realmente haveria terra e mão-de-obra disponível (como o PAEG indica), o capital é substituto no campo à mão de obra, enquanto que na indústria, complementar. Segundo ponto, a unidade de capital que fique entre ser utilizada no campo, ou na indústria, deverá ser utilizada nesta; a agricultura deve crescer em extensão e só utilizar maquinário quando o custo do transporte compensar a utilização deste. Como o seria, por exemplo, na agricultura paulista. O problema da agricultura seria a falta de demanda, e, por isso, dever-se-ia aumentar a demanda para que ela possa utilizar toda a sua capacidade. Em outras palavras, o problema da agricultura brasileira seria o ampliar-se ainda mais o desenvolvimento industrial .

Quando cresce em extensão, portanto, o setor agrícola permite não apenas que se maximize a produtividade marginal do capital, mas também a taxa de utilização da mão de obra, dois resultados altamente desejáveis em qualquer caminho de expansão para o desenvolvimento (DELFIM NETTO, s.d., p. 292)

Em terceiro lugar - a questão de a agricultura não responder os estímulos criados pela demanda da indústria - Delfim diz que os cálculos feitos pelo programa, e que os dados por ele utilizados não são abertos, e, por isso, fica difícil fazer qualquer crítica direta. 
Mas, se utilizando de um trabalho do Sr. Sergio Alberto Brandt, da Divisão de Economia Rural da Secretaria da Agricultura, mostraria que há elasticidade a longo prazo da oferta. "Diante desses dados a terceira proposição é rejeitada. Isso mostra que a conclusão do Programa é uma simples crença que emergiu da abundante bibliografia cepalina sobre o assunto" (DELFIM NETTO, s.d., p. 298)

Para, então, mostrar que essa "crença cepalina" não tinha respaldo com a realidade, é feito um esforço empírico-estatístico-teórico Delfim, os quais resultaram em dois trabalhos muito importante para análise da agricultura brasileira. $\mathrm{O}$ "Estudo Anpes $\mathrm{N}^{\circ}$ 5: Agricultura e Desenvolvimento no Brasil" e a tese de Doutorado defendida por Affonso Celso Pastore "A Resposta da Produção Agrícola aos Preços no Brasil"163. Os dois estudos chegam à mesma conclusão aqui apresentada, a saber, que haveria responsividade da oferta da agricultura aos preços no Brasil. Destaca-se, um ponto importante das duas pesquisas. Ambas não se concentram muito na região nordeste. A deficiência de dados é apontada como causa principal desse motivo.

O Estudo Anpes ao diagnosticar a agricultura nordestina considera que há um crescimento substancial da agricultura, "da ordem de 5\% ao ano", tanto nos produtos "exportáveis" quanto industrializáveis", "alimentícios" e de "consumo interno", nos anos de 1950-60. O estudo se admira da constância e homogeneidade do aumento da oferta, pois se deveria esperar um aumento a taxas desiguais de cada um desses produtos, dado que o mercado por eles são diferentes, o que deveria se esperar de sua demanda. Conclui-se, no trabalho, que a "agricultura do Nordeste ainda não está, possivelmente, voltada, de forma significante, para o mercado, pelo menos não recebe destes os estímulos suficientes para responder às modificações da demanda de produtos agrícolas" (DELFIM NETTO; PASTORE; CARVALHO, 1966, p. 73). Mesmo salientando que essa "falta de responsividade" não alterou em nada o aumento da produção dos produtos agrícolas, os quais vieram crescendo deveras fortemente. Já, Pastore, baseado na hipótese do Prof. T.W. Schultz, publicado no livro "Transforming Traditional Aggriculture", a qual afirmava que agriculturas tradicionais mantinham a racionalidade econômica, não sendo necessariamente importantes para a explicação diferenças culturais ou institucionais. No caso específico da região Nordeste, na conclusão, Pastore afirma que apesar dos problemas nos dados, havia sido "possível constatar a presença de ofertas positivamente

\footnotetext{
163 Tese orientado pelo próprio Delfim Netto.
} 
inclinadas com relação aos preços, e com coeficientes de regressão significantes" (PASTORE, 1968, p. 221). Haveria, então, indicativos de que mesmo em "uma área de agricultura predominantemente tradicional" os agricultores agiriam racionalmente (ou, de acordo com a racionalidade econômica capitalista).

Contudo, ao longo do trabalho, quando é analisada a região do Nordeste - e feitas as ressalvas das dificuldades de obtenção de dados e a sua aplicação naquela região existiam 5 produtos (algodão, arroz, cana, cebola, feijão) que não teriam apresentados resultados que evidenciassem elasticidades negativas, i.e., não responsivas ao preço. Já para o fumo, a mamona, a mandioca e o milho, sim, houve evidências de responsividade ao preço (com elasticidades-preços positivas).

Analisemos, então, como esse resultado se enquadraria com a política de não necessidade de realização de reforma agrária. São só alguns poucos produtos, e, como mostrado no estudo "Anpes 5", a oferta vinha crescendo vertiginosamente. E esse era o principal ponto para Delfim para a manutenção do desenvolvimento econômico. Como salientado, uma redistribuição de terras - mesmo defendida por Delfim, quando a propriedade privada serve apenas como forma de garantir renda a uma classe parasitária - não garantiria nada em relação ao desenvolvimento. E, a aposta por fornecer mais crédito, maior acesso à tecnologias e à informação no cultivo/plantio parece ter funcionado muito bem para garantir um aumento da produção de lá durante os anos que se seguiram. Ademais, o Nordeste não era mais o centro dinâmico da economia brasileira; seu possível atraso estava longe de ancorar o desenvolvimento. Muito mais, a aposta era de que os centros dinâmicos induziriam o desenvolvimento das regiões mais atrasadas. O principal, então, era garantir um aumento da produtividade por homem (com tecnologias de plantio mais eficientes), o que levaria a um maior aumento da inversão e maiores salários.

Delfim, ainda, volta-se à evidência paulista - sobre a qual não faltariam os dados exigidos para fazer uma análise mais rigorosa- dizendo que lá, de fato, quem acabou se beneficiando foi o setor comercial e o industrial, com os ganhos de produtividade transferidos da agricultura àqueles. Contudo, isso não seria possível afirmar em relação ao Nordeste, "onde o problema assume proporções críticas" (DELFIM NETTO, s.d., p. 42). O custo de alimentação no Nordeste seria bastante maior do que das regiões sul/SE, sendo reflexo de uma produtividade muito menor. Esse problema nordestino afetaria o desenvolvimento brasileiro como um todo, porquanto a integração "da economia nordestina na economia nacional implica na redução do salário real do setor industrial, o 
que, por sua vez, tende a reduzir o mercado consumidor" (DELFIM NETTO, s.d., p. 53). A solução seria ou incentivar a exportação de produtos agrícolas "a algum produto em que a região revelasse uma vocação particular" ou pela introdução de técnicas mais modernas. "Em qualquer um dos dois casos, entretanto, persistindo o excedente de mão de obra, a atual estrutura da propriedade criaria condições para a concentração dos benefícios nas mãos dos proprietários” (DELFIM NETTO, s.d., p. 55 , grifos meus).

Delfim sugere, então, que a distribuição de terras só aumentará a produção nos lugares cuja produção capitalista pague salários no ponto em que a produtividade marginal fosse igual ao "salário de subsistência" (modelo implícito de Lewis), e a "divisão da propriedade" poderia elevar a produção pois se passaria a maximizar a produção ao ponto da produtividade marginal ser igual a zero. A divisão da terra só teria sentido se houvesse i) "orientação técnica" e "crédito de custeio" e, ii) novos proprietários "integrados imediatamente num sistema de agricultura para o mercado", com o estímulo à formação "de um sistema de cooperação" (DELFIM NETTO, s.d., p. 57-58). Mas a divisão de terras estaria longe de resolver o problema do subdesenvolvimento, pois o aumento da produtividade agrícola só se refletiria em uma queda estrondosa do preço, sem o respectivo aumento da demanda. A reforma agrária só faria sentido se acompanhada de ainda maior industrialização e urbanização.

Delfim inclusive questiona o "direito de propriedade" acima de qualquer coisa. Pois existiriam "formas de propriedade altamente onerosas para a coletividade" (DELFIM NETTO, s.d., p. 62). Dever-se-ia abandonar "o direito natural”" como forma de explicar a natureza da propriedade privada, e subjugá-la ao "desenvolvimento econômico", posto que

aquele que vive apenas da renda de seus capitais, não contribuindo pessoalmente de nenhuma forma para a solução do problema mais amplo, que é o do estabelecimento de formas de convivência social mais adequadas à realização do homem, não tem porque exigir $\mathrm{o}$ respeito à sua propriedade (DELFIM NETTO, s.d., p. 63)

Delfim inclusive aceita que o salário dos trabalhadores da cana de açúcar seria regulado pela agricultura de subsistência, havendo um descasamento entre o que seria a "melhor alternativa para os proprietários" e "a melhor alternativa do ponto de vista social" (DELFIM NETTO, s.d., p. 66). Todavia, se esse era o caso em lugares muito específicos e limitados na região do Nordeste, essa perspectiva não estaria presente em outras regiões 
do Brasil. A agricultura na região sul caminharia "no sentido de transformar-se numa exploração capitalista" e os assalariados necessitariam "muito mais de uma legislação social capaz de abrigar os seus direitos" do que de terras. Por outro lado, no nordeste, haveria "sérios motivos" para crer que havia diferença entre a "produtividade particular e social da terra", em especial, na zona da mata. Contudo, se fosse para se fazer a reforma agrária, e esse diagnóstico se mantivesse com uma análise pormenorizada da realidade, “a reforma agrária para atingir seu objetivo [o desenvolvimento econômico](...) deveria ser portanto, regional e paulatina, feita com cuidado e dentro dos limites definidos pelos investimentos preliminares" (DELFIM NETTO, s.d., p. 72-73).

Observa-se que Delfim mantém-se coerente com o que chamara de "metodologia econômica". Caso os dados viessem a mostrar que o Nordeste funcionasse realmente como se estava imaginando que funcionava, a reforma agrária poderia ser usada como instrumento para a resolução do problema. Vemos, aqui, que o compromisso de Delfim é com o desenvolvimento econômico acima de tudo, mesmo que isso significasse questionar "o direito natural" da propriedade privada.

\subsection{Inflação: Monetarista ou Estruturalista?}

Mesmo discutindo alguns temas da inflação para Delfim no capítulo segundo da dissertação, agora apresenta-se sistematizada a discussão de um Delfim mais maduro sobre o tema. Em 1965, ele - com mais três autores ${ }^{164}$ - escreveu o "Estudo Anpes 1: Alguns Aspectos da Inflação Brasileira" para discutir, seguindo também a toada de bastante uso da econometria, as relações que estariam por trás do movimento inflacionário da economia brasileira.

A classificação dos economistas durante os períodos de 1955-1965 como entre uma corrente "estruturalista" e outra "monetarista" (em especial na América Latina), se fez algum sentido, não serve para classificar economistas como, por exemplo, Delfim Netto. Existe uma tentativa de classificação dessas duas escolas, mas que funcionam mais como de construção de um "espantalho" do que propriamente de um consenso. Mesmo quanto aos monetaristas, sobre os quais talvez se tenha uma delimitação mais bem aceita, é complicado dizer que há uma classificação consensual. O que se tentará argumentar é que, se existiram essas diferenças entre essas correntes - e certamente as há -se perderia muito fazendo um esforço para classificar Delfim em alguma delas. Mesmo porque a

${ }^{164}$ Pastore, A. C. Cipollari, P. Carvalho, E. P. 
própria definição entre elas é dúbia. No próprio livro sobre inflação, Delfim, ao explicar a escola "estruturalista", diz que se baseia em uma análise que argumenta que os aumentos de preços são consequências de ofertas insuficientes em determinados setores. Dentre eles, geralmente seriam mais apontados os desequilíbrios existentes no "comércio externo" e na "produção de alimentos". Numa nota de rodapé, vai ainda além, elogiando aquela "escola de pensamento", dizendo que é muito mais complexa do que ele expôs, e que "uma análise mais cuidadosa da teoria estruturalista mostra uma riqueza muito maior de hipóteses do processo inflacionário, dando ênfase a importantes aspectos do problema" (DELFIM NETTO, et al., 1965, p. 15). Contudo, já na página seguinte, ele parece querer afastar seu diagnóstico da "pecha" estruturalista, ao condicionar as proposições dessa escola somente às pressões advindas do setor agrícola. Diz ele, "desde que, de fato, existissem pressões derivadas do setor agrícola, a teoria estruturalista seria capaz de explicar, pelo menos em parte, os aumentos de preços” 165 Aqui, o autor dá a entender que o grande diferencial da explicação estruturalista para a inflação seria a existência de pressões advindas da oferta (total, ou parcialmente) inelástica do setor produtor de alimentos. Se essa realmente fosse a linha demarcatória da escola estruturalista, Roberto Campos, como exposto acima, deveria também ser tido como "estruturalista", e seu programa de governo (PAEG). Mas, novamente, a própria definição entre as diferentes "escolas" de interpretação do fenômeno inflacionário não é clara e nem consensual.

Entre aqueles que se debruçaram sobre essa problemática, está-se longe de haver um consenso, exatamente porque existe uma "área cinzenta" muito grande ${ }^{166}$. Talvez os extremos (branco ou preto) sirvam melhor para caracterizar um oponente (straw man) do que realmente para demarcar posições existentes. Serão mostrados alguns destes intérpretes, na tentativa de mostrar essa "zona cinzenta".

Alguns - como Júlio Oliveira (1964) e Hossein Akhavi-Pour (1975) - argumentam que a análise "estruturalista" é que existiriam "fricções" no ajuste da oferta às mudanças da

\footnotetext{
${ }^{165}$ Antes, no livro, o próprio Delfim explica que a escola estruturalista é mais complexa do que isso. Diz ele: "A explicação estruturalista afirma que os aumentos de preços derivam de pressões autônomas, geradas no bôjo do sistema econômico, e que se propagam na forma de aumentos de custos e de preços. Tais pressões decorrem da exostência de uma oferta inelástica em determinados setores, que não permite respostas adequadas aos estímulos da demanda. Como consequência, surgem desequilíbrios crônicos entre oferta e demanda, a gerar permanentes pressões para o aumento de preços. Os setores básicos onde geralmente se aponta existir tais desequilíbrios são os da produção de alimentos e do comércio exterior (DELFIM NETTO et al., 1965, p. 16).

166 "Zona Cinzenta" foi um termo utilizado por Primo Levi (1990), no livro "Os Afogado e os Sobreviventes", ao se referir que muitas vezes nos relatos que se ouve sobre Auschwitz, dificilmente são relatadas as "zonas cinzentas".
} 
realidade (variação de preferências dos consumidores, de funções de produções ou das razões entre as dotações de fatores). Dessa forma, a "inflação estrutural" poderia tanto ser por "mudança de demanda" (demand-shift) ou "mudança de custo" (cost-shift) ${ }^{167}$. Já Bielschowsky afirma que as teses estruturalistas apontariam que a partir da própria dinâmica do desenvolvimento (e crescimento da renda) "naturalmente" esta traduzir-seia "em desequilíbrios na estrutura produtiva" (BIELSCHOWSKY, [1988] 2012, cf. p. 2125). As estruturas produtivas mais apontadas por essa "escola" como causadoras do desequilíbrio seriam: i) a exportação de bens primários; ii) serviços de infraestrutura; iii) oferta rígida de alimentos; iv) insuficiência dos serviços de utilidade pública dada pelo inadequado sistema tributário. Já os monetaristas arguiriam ser possível haver desenvolvimento sem inflação, mesmo em regiões atrasadas. Contudo, "para descobrir quais são esses fatores", para a "escola estruturalista" ainda seria "necessário examinar as condições específicas de cada país, isto é, quais são suas características estruturais, institucionais e de dinâmica econômica". Não podendo haver, então, qualquer receita préconcebida para as causas inflacionárias.

Boianovsky (2012), em linhas gerais, tem uma posição similar à de Bielschowsky ([1988] 2012), porém, acrescenta que a controvérsia entre Furtado e os monetaristas no Brasil teria se originado na discussão dos problemas em relação ao balanço de pagamentos. Furtado discordaria que o desequilíbrio externo fosse causado pela inflação doméstica e excesso de demanda agregada (como seria assumido pelo FMI). A inflação seria causada pelas mudanças estruturais que eram parte do processo de industrialização dada pela disparidade entre as taxas de crescimento da renda e a capacidade de importar ${ }^{168}$. Essa diferencia inicial toma outras cores ao serem distinguidos dos monetaristas por acreditarem "que existia uma necessária relação entre desenvolvimento econômico e inflação" 169 Contudo, Cavalieri e Curado (2014, p. 71) argumentam que Furtado não era

\footnotetext{
${ }^{167}$ Essa é a opnião de Oliveira (1964, p. 326): "The reader will surely perceive that we are speaking of 'cost-push inflation' in its usual sense, that is, of a type of inflationary process caused by 'autonomous' increases in the nominal price of labour or other productive elements. Nevertheless, the definition may be broadened so as to include also the case of structural price-rises."

${ }^{168}$ Este autor, também, diferencia o debate que ocorria nos países centrais de inflação causada pela demanda (demand-pull) àquela causada pelo custo (cost-push). Pois, para ele, a tese estruturalista incluía tanto elementos de "demanda quanto de custo".

${ }^{169}$ Boianovsky, 2012, p. 286: "Latin American structuralists, in contrast to monetarists, believed there was a necessary relationship between economic development and inflation, which they interpreted as the outcome of unbalanced growth accompanied by changes in the composition of demand in economies with inelastic supply functions and relative downward rigidity of (mainly industrial) money prices". Esse é um outro debate, também complexo. Conferir Franco, 1996 e 2005 e a oposição em Curado e Cavalieri, 2015, sobre se seriam os autores "desenvolvimentistas" brasileiros também "inflacionistas".
} 
um "inflacionista", apenas que para ele a inflação seria melhor do que os remédios propugnado pelos monetários, mas que se deveria, sim, combatê-la ${ }^{170}$.

Resumindo: Oliveira e Hossein Akhavi-Pour argumentam que o diagnóstico "estruturalista" se refere a fricções de preços na oferta. Bielschowsky parece indicar que é uma incapacidade de resposta da oferta em determinados setores, e a existência de uma relação entre desenvolvimento e inflação. Boianovsky, de maneira semelhante, diz que existiria implicitamente no pensamento estruturalista algo como uma curva de Phillips, mas com o trade-off sendo inflação e redução das taxas de desenvolvimento ${ }^{171}$. Curado e Cavalieri parecem não concordar com essa definição, ao menos no concernente ao Furtado. Ainda mais, ao Bielschowsky dizer que a análise "estruturalista” dependeria das condições econômicas de cada país, significaria dizer que mesmo uma política estritamente "monetária" poderia ser aplicada, em determinada especificidade. Assim, a definição de escola estruturalista variaria entre uma espécie de metodologia própria e/ou leniência com a inflação e/ou um problema de fricções de preços na oferta. Sem definição peremptória $^{172}$.

Além disso, "inflação estruturalista" e "inflação de custo" serem considerados de mesmo escopo analítico, ainda, dependia-se da definição que se poderia ter de cada uma destas; a qual, como visto, variava. Agora, como a "escola estruturalista" é tida tradicionalmente como associada à Cepal, mesmo assim, lá não se pode ser dito haver homogeneidade na interpretação. Pois havia posições bastante dissonantes quanto ao diagnóstico do processo de desenvolvimento da inflação, a forma de remediá-la e, em especial, seu papel no

\footnotetext{
170“ $\mathrm{Da}$ mesma forma que Simonsen, pode-se afirmar que Furtado via na inflação um grave problema econômico a ser enfrentado." (CAVALIERI; CURADO, 2014, p. 68). e "O processo de industrialização, ao mesmo tempo em que criava pressões sobre a inflação, contribuiria, após a instalação da indústria pesada, para sua redução. $O$ processo de industrialização era, assim, dialeticamente a causa e a solução para a inflação estrutural dos anos 50. Já no contexto de desaceleração do crescimento do início dos anos 60, ganham espaço as causas fiscais da inflação" (CAVALIERI; CURADO, 2014, p. 71)

171، The structuralist position was, therefore, based on the implicit assumption of a nonvertical long-run Phillips curve, with the proviso that the relevant trade-off was between inflation and a reduction in the rate of economic growth, instead of unemployment. The monetarists, on the other hand, believed in a long-run vertical curve and sometimes even in a negative relationship between inflation and economic development". Boianovsky, 2012, 290.

${ }^{172}$ Carvalho (2015) em tese doutoralf defendida na Faculdade de Economia da USP, discute longamente diferentes abordagens sobre a inflação no Brasil. Para ele, o ponto fundamental da escola estruturalista parece ser de que a criação de meios de pagamentos se daria no bojo da sociedade (ou seja, a hipótese de dinheiro passivo) e não seria determinada por uma decisão a partir de uma estrutura governamental, de cima para baixo (RONCAGLIA, 2015, p. 51 et seq.)
} 
desenvolvimento econômico. Mesmo Boianovsky diferencia os colegas Cepalinos (Osvaldo Sunkel, Prebisch), neste quesito, de Furtado ${ }^{173}$.

Cabe aqui comentar um trabalho de cada autor que se considera fundamental para a continuação dessa discussão ${ }^{174}$. Há um consenso maior de que Prebisch definitivamente não defendia a posição de que o processo de desenvolvimento deveria ser acompanhado por inflação, ou ainda, de que esta poderia de alguma forma "azeitar" o crescimento econômico ${ }^{175}$. No texto "O falso dilema entre desenvolvimento econômico e estabilidade monetária" o argumento - em coerência com o próprio título - é de que a inflação não atua em prol do desenvolvimento ${ }^{176}$. E, ainda mais, que ela é extremamente danosa para $\operatorname{tal}^{177}$

Já o texto de Sunkel analisaria a inflação chilena com um "enfoque heterodoxo" como diz o próprio título. Ele mesmo, e não outros, estaria se distanciando de uma análise "ortodoxa", mas isso não significa afirmar, necessariamente, que o trabalho dele fosse "heterodoxo" e, nem que divergisse da "ortodoxia" da época. Neste trabalho, o autor classifica a inflação como tendo quatro elementos: "básicos", "circunstanciais", "cumulativos" e "os mecanismos de propagação". Metodologia que se tornaria, posteriormente, referência muito importante para os trabalhos tidos como "estruturalistas". Sunkel inclusive deixa claro que a continuidade do desenvolvimento econômico do Chile exigiria a supressão das pressões inflacionárias básicas, ou a

\footnotetext{
${ }^{173}$ Essas parecem ser as diferenças mais claramente fundamentais apontadas neste artigo. Todas as outras que poderiam haver, parecem que acabam se misturando e igualando o debate entre "estruturalistas" e "monetaristas"; o próprio autor discorda do posicionamento de Roberto Campos, que afirmaria que todo "monetarista" seria um estruturalista no longo prazo e, que, ao contrário, todo "estruturalista" seria um "monetarista" no curto prazo. Fazendo a distinção destes bastante nebulosa (BOIANOVSKY, 2011, p. 41). ${ }^{174}$ Prebisch, o primeiro economista a se destacar da Cepal e Sunkel pela influencia de seu texto na consolidação de uma teoria para a inflação "estruturalista", e onde Delfim cita de forma a aceitar a interpretação de que para o Chile, a reforma agrária faria sentido. Diz Bielschowsky que a "teorização estruturalista sobre a inflação" tivesse tido seu ponto de partida em Vásquez, 1956; mas teria sido com Sunkel sua sistematização e a partir dele que a explicação estruturalista teria sido progressiva disseminado. (BIELSCHOWSKY, 2012, p. 406).

${ }^{175}$ Soares, 2004 afirma, ainda, que a metodología de Prebisch era um exercício Marshalliano de análise da economia periférica. A sua proposta de industrialização dos países "periféricos", nada mais era, do que uma maneira de restabelecer a competição e a concorrência à nível mundial. Impedindo que os países "centrais" utilizassem de poder de monopólio no comércio, impondo preços não concorrenciais.

176 "No se crea, sin embargo, que la inflación es una alternativa. Si el sistema en que vivimos no puede crecer sin ella, la inflación será una alternativa frustránea, porque corroe la economía y debilita peligrosamente la cohesión social. Por donde no podríamos negar racionalidad a la inflación, no como instrumento para dar al sistema la validez dinámica, sino para llevarlo fatalmente a su desintegración."(PREBISCH, 1961, p. 26).

177 "Cometen un error de incalculables proyecciones políticas quienes creen que la inflación es el medio expeditivo para responder a las aspiraciones redistributivas de las masas populares. Como en el extremo opuesto lo cometen quienes la preconizan como instrumento de ahorro" (PREBISCH, 1961, p. 26).
} 
supressão dos obstáculos estruturais ao desenvolvimento econômico (o que seria a mesma coisa $^{178}$ ). Não havendo assim, possibilidade de troca entre "inflação" e “desenvolvimento", pois, a continuação do desenvolvimento seria o mesmo caminho para a superação da inflação, e nem que a inflação atuasse, em qualquer maneira, em prol ao desenvolvimento. Apenas, ele não entenderia a resolução desta como algo que dependesse apenas da “esfera financeira” (monetária) (SUNKEL, 1968, p. 571).

Por outro lado, o debate dessa época, fora da América Latina, dividia-se muito mais em termos de "inflação de custo" (cost-push) e de "inflação de demanda" (demand-pull) do que entre "monetaristas" e "estruturalistas". Para Machlup (1960), a diferença entre inflação de demanda e de custos estaria na ordem em que essas aconteceriam. A de demanda (demand-pull) exigiria primeiro uma "autônoma" expansão da demanda para depois haver - responsivamente (responsively) - um aumento de preços e salários. Ao contrário, a inflação de custos (um agressivo aumento de salários ou preço de materiais) seguida por um compensatório aumento de demanda. Para Schultze (1959), a inflação seria do tipo "cost-push" caso preços e salários fossem determinados por custos. Por outro lado, se os preços e os salários variassem em relação a mudanças na demanda (demandpull), seria uma situação de inflação dada pela demanda. Ou seja, uma restrição na demanda (como resposta a um aumento de preço) não levaria a um crescimento no desemprego (SCHULTZE, 1959, p. 01). A conexão entre a "escola estruturalista" e os termos de "demand-pull" e de "cost-push" é ainda menos consensual. Para Schultze (1959), a inflação de custo teria muito a ver com a "estrutura de preços e salários" na economia, e com as "rigidezes na estrutura de preços na economia" (SCHULTZE, 1959, p. 02 e p. 09). Parece que segue bastante de perto as noções, aqui expostas, da escola estruturalista. Até Oliveira (1964) diz que a definição de "inflação de custos" pode ser "ampliada" como para incluir o caso de "aumentos de preços estruturais". E cita Hicks (1962), quando este define a interpretação de demand-pull inflation como a inflação devida ao excesso de gasto. Já a cost-push inflation viria de aumento de preços em particulares produtos, devido, inicialmente, a causas que poderiam vir tanto por causa do lado da oferta, como do lado da demanda (HICKS, 1962).

\footnotetext{
178“ (...) no existe mas que una alternativa: la supresion de los obstaculos estructurales al desarrollo economico, o lo que es identico, la elimination de las presiones inflacionarias basicas" (SUNKEL, 1958, p. 594).
} 
Humphrey (1998), inclusive, diz que a tese de "inflação de custo" seria bastante antiga, cuja raiz estaria em um livro de Sir James Stuart, "Investigação a Respeito dos Princípios de Economia Política", de 1767. E, oposta a ela, teria sempre havido a "teoria standart monetarista dos preços”. Ele parece, então, identificar similaridades entre economistas que seriam partidários destas correntes de pensamento, o suficiente, para classificar o debate de mais de 300 anos como sendo de uma matriz fundamental: "inflação de custo" versus "monetaristas" (HUMPHREY, 1998). Um desses debatedores importantes discutidos por Humphrey como grande pai da "escola de cost-push inflation" é Thomas Tooke, o qual define o preço dos bens dado a partir dos auferimentos dos fatores: salário, renda e lucro ${ }^{179}$. Sendo assim, ele pleiteia que uma diminuição nos juros, de fato, atuaria em causa de diminuição dos preços, pois baratearia a produção.

Como visto no capítulo segundo dessa dissertação, Delfim - ao tratar da inflação em 1959 - define, dessa forma, o preço de uma mercadoria:

Como sabemos é, em geral, possível dividir o preço de mercado de qualquer produto, nas seguintes parcelas: o custo das matérias-primas, os salários, o lucro da empresa e uma outra parcela representada pelos juros, aluguéis, mais ou menos fixada institucionalmente e que, por questão de conveniência, chamaremos de renda. $\mathrm{O}$ custo da matériaprima, por sua vez, é o seu preço de mercado e pode, também, ser desdobrado naquelas três parcelas. A medida que continuamos esse desdobramento, vamos verificando que o preço de mercado de qualquer bem pode ser desdobrado em termos dos rendimentos auferidos pelas pessoas (físicas ou jurídicas) que participaram do processo de produção (DELFIM NETTO, 1958d, p. 91)

Assim, como em concordância com Tooke, parte do aumento dos preços poderia advir do aumento do custo de produção, era possível diminuí-los, ao se diminuir os custos. Contudo, como diz Delfim, os empresários no Brasil, naquela época, "estavam acomodados" e conseguiam recalcular seu lucro sempre em relação ao custo (uma espécie de Mark-up constante); os assalariados resistiriam a uma redução do salário real (dado o alto nível de emprego), e o Governo, continuaria com apolítica de défices como forma demagógica de seguir mantendo "uma impressão de prosperidade geral."180.

\footnotetext{
${ }^{179}$ No livro, Tooke faz a destinção entre "wages" e "salaries", mas essa diferença parece irrelevante aqui e ambos foram traduzidos por uma só palavra, a saber, "salário".

180 "Os empresários acostumados a uma política de compra que dá sempre certo e a calcular uma margem de lucro fixa como porcentagem do custo, resistem à sua redução; o alto nível de emprego dá condições cômodas para os empregados resistirem a redução do salário real, isto é, os empregado têm condições para impedir que o salário cresça mais lentamente do que o índice de custo da vida; o Governo, (...) pode continuar calmamente em sua política de déficits orçamentários (...) pois a inflação dá uma impressão de prosperidade geral” (DELFIM NETTO, 1958a, p. 142, grifos meus).
} 
A posição desta dissertação é que o trabalho de Delfim, publicado pela Anpes tem muito mais similaridade com o trabalho de Sunkel, do que com uma visão "monetarista" ou de "ligada à demanda" da moeda da economia. Esse posicionamento é tão patente - como se espera mostrar - que surpreende que precise ser dito. Contudo, também por "Estruturalismo", "monetarismo", "demanda-pull" e "cost-push" serem arquétipos (e como tal, eles nunca se encaixarem perfeitamente com a realidade) nos parece inócua a classificação de Delfim em alguma destas. Dessa forma, melhor seria analisar o diagnóstico dos autores em questão, e, só a partir daí, traçar paralelos e dissimilitudes ${ }^{181}$. Querer, a priori, fazer uma leitura de um autor com essas categorizações estritas não ajudam nesta empreita ${ }^{182}$.

\subsubsection{A visão independente de Delfim}

Espera-se ter mostrado que não uma discussão estanque era o enquadramento dessas "escolas", e que muito se confunde ao se tentar defini-las cabalmente. Assim, mais do que enquadrar Delfim em uma dessas categorias, considera-se mais útil expor o diagnóstico deste, talvez, conseguindo-se retirar alguns preconceitos que possa vir a se ter sobre ele. Em primeiro lugar, para Delfim, o desenvolvimento trás, sim, tendências inflacionárias. Mas, a inflação não seria condição sine qua non para o desenvolvimento. Somados ao conflito entre consumo e investir, um país em desenvolvimento ainda sofreria de mais cinco outros "problemas importantes" que acentuariam as "pressões inflacionárias latentes nas economias subdesenvolvidas" (DELFIM NETTO et al., 1965, p. 08): i) O problema demográfico: o desenvolvimento diminui a mortalidade, levando a altas taxas de crescimento demográfico. Este crescimento exige maiores investimentos em infraestrutura "cuja relação produto/capital é reconhecidamente mais baixa que a dos investimentos feitos diretamente nos setores primário e secundário do sistema” (DELFIM NETTO et al., 1965, p. 08); ii) A assimilação de novas técnicas, que poderia não levar a

\footnotetext{
${ }^{181}$ Peláez, também afirma que é muito difícil definir o que seria a "teorização estruturalista”, a qual diz que não é uma "caixa compacta de ferramentas" como a seria a Chicago Scholl. Ele definiria-a a partir da sensação de que a Grande Depressão havia sido um marco fundamental àquela escola no enfrentamento da divisão tradicional internacional do comércio. Ou seja, sem nenhuma relação à forma de encarar o processo inflacionário e/ou seu diagnóstico. Citando Werner Baer, e kerstenetzky, 1967: "É êste o fundamento empírico do estruturalismo. Salientou-se, ainda, que a década da Depressão foi mais importante do que qualquer outro período, tendo em vista que "a depressão da década de 1930 constituiu um incentivo à industrialização através de um mecanismo automático de proteção que é ainda mais interessante do que as duas guerras mundiais, pois temos aqui duas fôrças econômicas internas influenciando as atividades econômicas internas... É preciso salientar que essa industrialização foi quase totalmente financiada pelas poupanças internas ...” Peláez, 1971a, p. 07.

${ }^{182}$ Claro que é impossível se livrar de todos os preconceitos na leitura. Mas, sem dúvidas, existe uma boavontade em entender o argumento que se faz necessária.
} 
uma "alocação ótima dos recursos disponíveis", pois ao se incorporar técnicas economizadoras de mão-de-obra, "haverá diminuição do crescimento potencial da oferta de bens e serviços, como menor será a capacidade de absorção da crescente oferta de mão de obra" (DELFIM NETTO et al., 1965, p. 09); iii) O setor externo no qual haveria, naturalmente um desequilíbrio no balanço de pagamentos nos países subdesenvolvidos que tem "exportações tradicionais", cujo aumento cresce com lentidão e o aumento da necessidade de importação tende a se ampliar com maior rapidez do que "o decréscimo do coeficiente de importação" (DELFIM NETTO et al., 1965, p. 09). O próprio défice daria indicações "aos empresários nacionais sobre novas possibilidades de investimento", mas "contém em si, importantes estímulos inflacionários, porque o processo de substituição das importações se faz, em geral, a custos monetários mais elevados" (DELFIM NETTO et al., 1965, p. 09); iv) Aumento inerente da participação do governo na economia com o desenvolvimento. $O$ aumento da urbanização levaria a uma necessidade maior de o governo investir em "escolas, hospitais, redes de águas e esgoto, etc" (DELFIM NETTO et al., 1965, p. 89), e o aumento do gasto em custeio dessas novas atividades. Só isso já levaria a um aumento do gasto público com a própria "máquina administrativa" do governo que aumentaria. Por outro lado, muitos dos investimentos em infraestrutura - que levariam ganhos de economia externa à iniciativa privada - também seriam deixados a cargo do governo. O gasto se agravaria num país como o Brasil, por esse ter um baixo adensamento populacional por $\mathrm{Km}^{2}$, pois a maioria dos gastos em investimentos do governo seria indivisível (uma escola, um hospital, uma estrada, uma rede de água e esgotos) (DELFIM NETTO et al., 1965, p. 94); v) "efeito imitação do consumo": os consumidores quereriam atingir níveis de consumo e lazer iguais aos de países desenvolvidos, sem, contudo, fazerem parte de economias de países desenvolvidas. Esse efeito oneraria tanto mais o setor público, quanto o privado. Contudo, para Delfim, essas pressões inerentes seriam incapazes de explicar uma inflação da "ordem de $80 \%$ ao ano" (DELFIM NETTO et al., 1965, p. 08).

Tendo feito essas ressalvas, o estudo Anpes 1 tenta salientar "alguns aspectos da inflação brasileira" de forma a impedir que todas essas tendências inflacionárias se tornassem um processo inflacionário de $80 \%$ ao ano. É importante ter esses pontos em mente, pois qualquer análise sua partiria, então, sempre do pressuposto de que haveria aumentos de preços que seriam resultado do crescimento (e geralmente são questões de curto prazo) e haveria os que são resultados de políticas (ou despolíticas) de toda sorte. 
Delfim, ao tratar do modelo mais geral da inflação não fala em causas, pois as ligações seriam mais sutis, com mecanismos mais complexos que se realimentariam. Nesse sentido, trata por variáveis explicativas, sendo quatro as mais importantes: défices do setor público, pressões de custos dos reajustamentos salariais, pressões de custo das desvalorizações cambiais e as pressões derivadas do setor privado da economia. A metodologia segue sempre o padrão de explicar o fenômeno e testá-lo empiricamente utilizando-se da econometria, do teste com dados anuais, sempre se segue outro com dados trimestrais.

O modelo geral consiste em explicar o preço de um ano, divido pelo preço do período anterior $^{183}$, em relação a emissão de moedas, ao custo de importação e ao salário (todos, também, divididos por seus valores correspondentes do período anterior) e a "aceleração da inflação"184. O modelo estimado seria, então, como se segue ${ }^{185}$ :

(I) $\frac{\widehat{\mathrm{P}} t}{\mathrm{Pt}-1}=\mathrm{a}_{0}+\mathrm{a}_{1} \frac{M \mathrm{t}}{M \mathrm{t}-1}+\mathrm{a}_{2} \frac{\mathrm{Ct}}{\mathrm{Ct}-1}+\mathrm{a}_{3} \frac{\mathrm{Wt}}{\mathrm{Wt}-1}+\mathrm{a}_{4} \mathrm{~A}_{\mathrm{t}}$,

O componente "aceleração da inflação" significaria uma situação de ainda maior dificuldade em seu combate, mesmo que todas as outras causas estivessem controladas. Esse modelo se mostra interessante, por diversos motivos. O primeiro é que ele indicaria realmente que os preços estariam sendo afetados por mais variáveis do que simplesmente os meios de pagamento poderiam indicar. Para Delfim, isso é um indicativo de que a equação tradicional "monetarista" de demanda de moeda $(\mathrm{M} / \mathrm{V}=\mathrm{PY})^{186}$ não serviria para explicar "de um ponto de vista puramente empírico" (DELFIM NETTO et al., 1965, p. 35) as variações de preço. Mesmo se os meios de pagamento tivessem uma "oferta inelástica", i.e., fossem mantidos constantes, o sistema econômico encontraria o equilíbrio de alguma forma; fosse pela diminuição da demanda por moeda, fosse pelo aumento da velocidade-renda. Diz Delfim que se observam esses fatos, ao se analisarem os "intermediários não-bancários", que aumentariam o volume de crédito "sem modificar o total dos empréstimos bancários" e na adoção de "orçamentos de caixa"187, o que

\footnotetext{
${ }^{183}$ Isso equivaleria a taxa de inflação mais 1, pois: $\frac{\widehat{\mathrm{P}} t}{\mathrm{P} t-1}=1+\mathrm{r}$, sendo " $\mathrm{r}$ " a taxa de inflação. 184“"Calculada pela diferença entre as taxas de inflação nos dois anos anteriores".

185 Delfim tem toda uma seção do livro dedicada a confirmer empiricamente se existem pressões ${ }^{186} \mathrm{M}=$ quantidade de moeda; $\mathrm{V}=$ velocidade da moeda; $\mathrm{Y}=$ renda total real disponível; $\mathrm{P}=$ preço

187 O orçamento de caixa é - ao contrário do de competência - uma forma de administrar os fluxos nos momentos em que eles realmente acontecem. Assim, só conta como positivo o dinheiro que entrou (ao contrário da venda efetuada) e, só conta como negativo o dinheiro que realente saiu (não no momento da compra, mas no momento do pagamento).
} 
reduziria a demanda por moedas por parte das empresas, e aumentaria a velocidade-renda da moeda. Mesmo assim, se o "aperto monetário" persistisse, as empresas se deparariam com dificuldades financeiras, reagindo ao seu problema de liquidez com uma diminuição no volume da produção. Pois os empresário estariam acostumados à "idas e voltas da política financeira" manteria sua participação no produto "através de um "Mark-up" relativamente fixo" (DELFIM NETTO et al., 1965, p. 36).

Esse ponto é ainda melhor entendido ao se analisar o estudo Anpes 2, intitulado "O Papel dos Intermediários Financeiros não Bancários no Processo de Desenvolvimento Econômico ${ }^{1 "}$ escrito por Pedro Cipollari ${ }^{188}$. Nesse estudo é sobrelevado o papel que tem os "intermediários não bancários" a impedirem que um aperto monetário aja rapidamente no combate da inflação:

Uma política monetária que tenha por objetivo reduzir a oferta de moeda, através quer do controle das emissões, quer da manipulação das taxas de reservas compulsórias do sistema bancário, poderá não ter sucesso nesse mister, se os intermediários financeiros não bancários tiveram sua importância aumentada dentro do sistema econômico (CIPOLLARI, 1965, p. 02).

Não adiantaria, assim, fazer um aperto monetário, porque a economia responderia de alguma forma envolvendo uma magnitude muito maior do sistema econômico do que propriamente só aquelas empresas que poderiam ser, talvez, consideradas menos produtivas. Pode-se ver claramente como isso era visto por Delfim, no estudo Anpes 4, "Tentativa de Explicação das Causas que Determinaram a Expansão dos Meios de Pagamentos em 1964 e 1965”. Nesse texto, Delfim questiona a análise que o FMI teria feito ao visitar o país, estranhando que "as aplicações do sistema bancário" teriam crescido $85 \%$, mesmo em um período de aperto monetário e, a partir dessa análise "as autoridades monetárias" teriam passado a estudar medidas de controle ainda maior de crédito. Ademais, concordando com o diagnóstico de Cipollari, o autor afirma que a economia - mesmo com um aperto monetário - teria "substancial liquidez" para financiar aumentos de preços, o que tornaria políticas monetárias anti-inflacionárias menos eficazes. Em comparação aos anos de julho/1963 - julho/1964 cada cruzeiro emitido teria gerado 3,285 em meios de pagamento, já, no período de um ano posterior (julho/1964 julho/1965) cada cruzeiro emitido gerou 5,521de meios de pagamento.

\footnotetext{
${ }^{188}$ Também (juntamente com Affonso Pastore e Eduardo Pereira de Carvalho) co-autor de Delfim no estudo Anpes sobre a inflação. Este trabalho Anpes 2 fora orientado por Delfim.
} 
Tendo esse fato em vista, Delfim quer mostrar de qualquer maneira que um aperto monetário ainda maior só iria causar uma crise sistêmica na economia. $\mathrm{O}$ aumento de meios de pagamentos havia se dado, "com praticamente o mesmo volume emitido" entre os dois anos (DELFIM NETTO, 1966, p. 10), pois o Banco do Brasil diminuiu consideravelmente o número de depósito que mantinha em caixa 12\% dos depósitos em julho de 1964 e, em 1965, representou 7\%. Aqui cabe uma análise do período: o PAEG havia feito uma contração creditícia muito grande em vistas de diminuir a inflação. Muito provavelmente, como salientado por Delfim, muitas empresas e pessoas vendo-se sem liquidez, correram para o Banco do Brasil, e este foi em socorro. Dessa maneira, fica mais claro o potencial de quebra sistêmica, pois o maior envolvido acabou sendo o Banco do Brasil, e assim continuaria por algum tempo (pois ainda havia 7\% em caixa, sendo que aparentemente ele mantinha em média $10 \%$ nos anos anteriores $)^{189}$, podendo ainda financiar as empresas - mesmo a custo altíssimo - por algum tempo, sem surtir efeito na diminuição efetiva da moeda e nos preços.

Delfim vai ainda mais além, criticando a análise "quantitativa da moeda". Em primeiro lugar, cita Selden (1956), que com Friedman, escreveu um livro sobre a teoria quantitativa da moeda, (ou seja, um autor "monetarista") que afirmou que a "velocidade da renda depende, pelo menos, do custo de reter a moeda, do custo de reter substitutos de moeda e do nível de renda real "per-capita". Depois, cita Philip Cagan $\left(1956^{190}\right)$, da Universidade de Chicago, em um artigo, (o qual seria resultado de um trabalho para o Nber [National Bureau of Economic Research] sob, também, a "direção geral de Milton Friedman) no qual este teria afirmado que o determinante da razão entre moeda e depósito seria o "conhecimento da taxa esperada de rendimento dos depósitos bancários" e também a variável "renda-real per-capita". Se assim o fosse, então a velocidade da moeda - que seria um componente da procura - e a relação entre depósito e moeda - componente da oferta de moeda - seriam variadas pelas mesmas variáveis, o que violaria "a condição de independência das duas relações, e [a] torna, consequentemente muito menos útil a demanda de moeda para a previsão dos aumentos de preços" (DELFIM NETTO, 1966, p. 12).

\footnotetext{
${ }^{189}$ Destaca-se que o PAEG teria feito um aperto monetário muito forte como forma de combater a inflação. ${ }^{190}$ Delfim não diz qual seria o texto, mas imaginamos que seja esse de 1956. É interessante que este artigo, apesar de concluir que a velocidade da moeda estaria correlacionada com a quantidade ofertada de moeda, mantém estrito na teoria quantitativa de moeda. Inclusive, foi um grande influenciador das "expectativas racionais" de Sargent (1976) posteriormente.
} 
Fica claro, então, como para Delfim, a equação M.V=P. Y (ou qualquer uma de suas variantes) não conseguiria explicar/prever o aumento de preços de forma , "O ponto para o qual desejamos chamar atenção é o de que a relação entre $v_{t}$ [velocidade da moeda] e $h_{t}{ }^{191}$ não admite nenhuma interpretação mecânica simples e muito menos sugere qualquer relação de causalidade" (DELFIM NETTO, 1966, p. 13). Pior, tentar aumentar o compulsório, ou obrigar os bancos a manterem caixas elevados possibilitaria "toda a sorte de operações clandestinas, que poderão contribuir para a desmoralização de todo o Sistema Bancário Nacional" (DELFIM NETTO, 1996, p. 17).

O que Delfim diz, basicamente, é que o sistema (mesmo que entre limites) criará a quantidade de meios de pagamentos que for necessária para não entrar em colapso, mesmo que "apelando" a operações clandestinas. Isso é muito perto de dizer que "M" (emissões) são realizadas como resposta aos preços, e não vice-versa. Chegando a uma interpretação "perigosamente" perto de uma "emissão" passiva e não ativa. A solução, então, proposta por Delfim, seria diminuir o "encaixe obrigatório" (compulsório) dos bancos e o banco central "esterilizar" o encaixe restante. Ou seja, aumentar a liquidez da economia pelos Bancos privados e diminuir a parcela desta proporcionada pelo Banco do Brasil. Esse aumento de liquidez promoveria uma redução da taxa de juros efetiva. Resultado esse em completo descompasso (diametralmente, pode-se dizer) àquele das “autoridades monetárias" da época (comandadas por Bulhões e Campos) e do FMI.

Comparando essa interpretação dos meios de pagamentos com aquela feita por Ignacio Rangel no livro "Inflação Brasileira", argui-se que há muitos pontos em comum. Em primeiro lugar, Rangel ao usar a equação quantitativa da moeda (M.V = Y.P), diz que uma "variação autônoma do nível de preços" (para cima), em um primeiro momento transformaria a equação em uma desilgualdade $(\mathrm{M} . \mathrm{V}<\mathrm{Y} . \mathrm{P})$, e a solução da economia seria a retirada de produtos do mercado de tamanho " $y$ " tal que a equação voltaria a resultar em M.V = (Y-y).P, retornando ao equilíbrio. Assim, o aperto monetário

\footnotetext{
${ }^{191} h_{t}$ é a relação entre o "aumento da moeda em poder do público" e o "aumento dos meios de pagamentos". Delfim ainda tenta explicar porque uma ampliação dos meios de pagamento poderiam não causar aumentos de preços. Delfim considera duas equações: $\mathrm{p}_{\mathrm{t}}=\mathrm{a}+\mathrm{b} \mathrm{Y}_{\mathrm{t}}$ (I, equação que exprime uma relação entre $\mathrm{o}$ "montante de seus ativos líquidos que o público deseja reter como moeda corrente em seu bolso (p) e o PIB nominal $(\mathrm{Y})$. A segunda equação, seria a definição de velocidade da moeda: $\mathrm{V}_{\mathrm{t}} \mathrm{M}_{\mathrm{t}}=\mathrm{Y}_{\mathrm{t}}$, chegando em $\mathrm{p}_{\mathrm{t}}=$ $\mathrm{a}+\mathrm{bV}_{\mathrm{t}} \mathrm{M}_{\mathrm{t}}$; a partir dessa equação, ao se dividir por $\mathrm{M}_{\mathrm{t}}$ toda ela, chegar-se-ia a: $\mathrm{h}_{\mathrm{t}}=\left(\mathrm{P}_{\mathrm{t}} / \mathrm{M}_{\mathrm{t}}\right)=\left(\mathrm{a} / \mathrm{M}_{\mathrm{t}}\right)+\mathrm{bv}_{\mathrm{t}}$. "Essa expressão ajuda a compreender porque a redução de $\mathrm{h}_{\mathrm{t}}$ (acompanhada de um substancial aumento de $\mathrm{M}_{\mathrm{t}}$ ) não produziu maiores aumentos de preços. Notemos, que do ponto de vista da política monetária, as variações de $\underline{b}$ são de importância primordial, pois produzem modificações de $\mathrm{M}_{\mathrm{t}}$ sem qualquer modificação compensatória em $\mathrm{V}_{\mathrm{t}}$, o que produz tensões maiores sobre o nível de preços" (DELFIM NETTO, 1966, p. 10)
} 
diminuiria a produção total sem, necessariamente a diminuição dos preços da economia. Essa é a mesma interpretação que Delfim tem sobre a resposta dos "empresários" que manteriam sua participação no produto a partir de "Mark-up" fixo dado que estariam acostumados à "idas e voltas da política financeira”.

Rangel continua, afirmando que

a retenção dos estoques, no plano da empresa, implica numa séria modificação de sua equação econômico-financeira. Com efeito, cresce o realizável da firma, à custa de seu disponível, isto é, da caixa e dos depósitos bancários. A empresa reage, recorrendo ao sistema bancário, para restabelecer o seu disponível, e o banqueiro não vê nenhuma razão para recusar-se a socorrer a firma, tanto mais quanto seu realizável, inflado pelos estoques adicionais, responde, na análise contábil corrente, por um elevado índice de solvabilidade. Isso, não obstante, vai afetar negativamente o equilíbrio de caixa do sistema bancário, movimento esse que, direta ou indiretamente, se vai exprimir como $<<$ problema de caixa do Banco do Brasil >>. É para socorrer a caixa do Banco do Brasil que o governo emite, o que quer dizer que a inflação não se gera no nível do orçamento da União, uma vez que tem origem no bojo da economia, por efeito de movimentos autônomos da empresa privada. O governo, ordinariamente, apenas presta-se a fazer o serviço que dele exige, através do mecanismo descrito, o sistema econômico.

Noutros termos a emissão não é o ponto de partida da inflação, mas o seu ponto de chegada, isto é, sua culminacão. (...)" (RANGEL, [1963] 2012, p. 09)

Feita a emissão, restabelece-se a equação de trocas em nível superior, a saber: $\mathrm{M}_{1} . \mathrm{V}=\mathrm{P}_{1} . \mathrm{Y}$.

$\mathrm{Na}$ biblioteca doada por Delfim a qual se encontra na Faculdade de Economia da Universidade de São Paulo (FEA/USP), este livro do Rangel está amplamente grifado e comentado por ele. A parte aqui exposta que se encontra grifada foi por ele assim feita a lápis; por outro lado, a parte que se encontra grifada e com destaque em negrito, foi a parte que foi grifada e bastante destacada com flechas dos dois lados apontando-a. Nela contém, em palavras diversas, o mesmo arrazoamento que mostramos Delfim fazer. A consequência lógica de um maior aperto monetário seria - em um primeiro momento maior inflação até o sistema não conseguir se proteger, e a persistência nessa estratégia significaria em crise sistêmica envolvendo todo os principais setores da economia.

Vimos que ao menos parte das emissões surge - para Delfim ${ }^{192}$ - no bojo da economia (ou, pelo menos, estaria fora do controle direto do governo e/ou banco central). Essa posição vem em coerência com Delfim, se imaginarmos que a análise inflacionária dele

\footnotetext{
${ }^{192}$ E para Rangel.
} 
foi bastante influenciada por Bresciani-Turroni. Este, ao discutir a inflação na Alemanha, insiste bastante no ponto de que - iniciado o processo inflacionário - a criação da moeda se daria, também, pela dinâmica social, e não só pela disposição do banco central em emitir ${ }^{193}$. Turroni nota que após a reforma do marco alemão (instaurando uma nova moeda), com o governo contraindo a moeda, seria esperada uma redução dos meios de pagamentos, mas, o que houve, teria sido por um aumento destes, porque boa parte do dinheiro usado outrora era considerado "ilegal", i.e., formas alternativas de pagamentos que não o dinheiro oficial:

It is not difficult to explain why the monetary reform had been accompanied not by a contraction but by an actual increase in the quantity of legal money in circulation. The lack of confidence in the paper mark being lessened, consumers, producers, and merchants ceased to be pre-occupied with the necessity of reducing their holdings of paper marks to the minimum. In other words, the velocity of circulation of paper marks declined. That helped to create the need for a new circulating medium, so that new paper marks could be issued within the limits of this need, without imperiling the stability of the exchange. Besides, the rentnmark and the new paper marks took the place of the various auxiliary monies, legal and illegal, which had been issued in the autumn of 1923 and of foreign exchange (BRESCIANITURRONI, 1968, p. 348)

Essa era uma hipótese que poderia ser testada no cenário de 1965 no Brasil, no qual o governo (PAEG) "enxugou" a moeda "legal”, e, mesmo assim, os meios de pagamento aumentaram. Talvez não por meio de moedas "ilegais" (como diz Turroni), mas um crescimento dos "intermediários financeiros não bancários" e, principalmente, dos “empréstimos bancários do Banco do Brasil” como indica o estudo Anpes ${ }^{194}$.

Além disso, o segundo termo do modelo de Delfim para explicar o aumento de preços da economia é o custo com importações. Este sendo um choque exógeno que poderia tomar grandes proporções e deveria ser levado em conta ao se desenhar uma política antiinflacionária. Vimos frisando essa questão ao longo da dissertação, em especial ao discutir o livro sobre o café. Dois pontos são salientados novamente; i) o desequilíbrio

\footnotetext{
${ }^{193}$ Cabe destacar, também, a influência que os "especuladores" tinham em desestabilizar a economia. É dessa opinião sobre Turroni dois analistas dele, Kurz (1998) e Bini (1992).

${ }^{194}$ Em outro livro, escrito por Turroni alguns anos mais tarde daquele da inflação na alemanha, e já comentado nesta dissertação como tido por grandes elogios por Delfim, "Corso di economia Politica", Turroni também questiona a validade da teoria da moeda: "Le considerazioni precedenti ci mostrano che se la teoria quantitativa è intensa nel senso di uma proposizione la quale afferma che le variazioni del livello generale dei prezzi sono proporzionali alle variazioni della quantità di moneta - onde il valore dell'unità monetária è inversamente proporzionale ala massa monetária - quella teoria certamente non corresponde ai fatti, especialmente nel caso di grandi variazioni di M" (BRESCIANI-TURRONI, 1949-1950, p. 256, grifos meus).
} 
entre os produtos de exportação de um país em desenvolvimento e suas exportações levando a uma "tendência a um déficit crônico no balanço de pagamentos"; ii) o processo de substituições de importações "induz a uma elevação dos preços, como consequência da necessidade de se reservar mercado interno para a indústria nacional" (DELFIM NETTO et al., 1965, p. 81-82). O que aconteceria - em consonância com o dito ao se analisar "O Problema do Café" - é que as desvalorizações cambiais são feitas como tentativa de se manter equilibrado o balanço de pagamentos, o que, por sua vez, provocaria aumentos de preços "no bimestre seguinte". O aumento de preços provocaria uma queda no preço das importações, elevando-se a demanda por essas. Pressionando o sistema para novas desvalorizações. Uma forma de se superar esse processo seria o de aumentar os ganhos de escala da produção nacional (diminuindo-se o custo) no setor de bens de produção cujo mercado interno seria pequeno. A solução seria a exportação, o que, por outro lado, também atuaria no sentido de aumentar os efeitos inflacionários. Dever-se-ia fazer desvalorizações seletivas, para incentivar-se a exportação de certos produtos. Não teria sentido, destarte, incentivar produtos tradicionais (como o café) ou produtos com ofertas inelásticas a curto prazo - comentado por Delfim, que pareceria ter sido o caso da carne, que apenas teria feito com que o preço interno desta aumentasse até igualar os preços externos medidos em moeda nacional, sem aumentar a produção podendo gerar, apenas, uma "inflação gratuita". Se fosse feito corretamente, o direcionamento da produção para o setor externo poderia resolver o problema do balanço de pagamentos e, ainda, empregar a mão-de-obra industrial.

Cabe ainda comentar sobre as pressões de custos de importação em relação as "regressões estatísticas" feitas no livro em relação aos preços setoriais. Em relação ao "índice do custo da construção na Guanabara" o custo de importação foi se mostrado relevante até 1953, e depois disso não tanto. A explicação dos autores é de que até 1953 a importação era muito importante no custo da construção, exemplifica com a produção nacional de cimento que parece ter tomado proporções a não mais ser necessária sua importação. Em entrevista concedida pelo próprio Delfim Netto juntamente com Paulo Yokota e Akihiro Ikeda (seus companheiros) foi tratado sobre como havia sido difícil a superação do problema do monopólio do cimento no Brasil. De acordo com eles, o cimento havia sido um grande problema no desenvolvimento pois o preço era controlado por oligopólios que 
atuavam como monopólios repassando sempre o custo para os demais setores da economia, onerando a construção civil, e, assim o desenvolvimento nacional ${ }^{195}$.

Por último, a terceira variável do modelo geral de inflação são os reajustes salariais. Estes seriam altamente inflacionários - mesmo que feitos na proporção do custo de vida - pois , e.g., a taxa de câmbio mantida fixa, haveria um ganho no poder de compra dos assalariados, além da depreciação do custo de vida. Por outro lado, se o salário fosse corroído pela inflação durante um período de tempo, isso significaria que o salário real não teria sido nem o do início do período, nem do final, mas sim o salário médio do período. Um reajustamento, assim feito, nesse nível, estaria muito acima das perdas inflacionárias. A esses reajustes, "os setores não assalariados da economia não assistiriam passivamente a tal redistribuição da renda" (DELFIM et al., 1965, p. 78). A única solução seria que o governo coordenasse os reajustes salariais "impondo a assalariados e empresários reajustamentos compatíveis com as taxas de inflação previstas" (DELFIM NETTO et al., 1965, p. 79). Não se poderia deixar aos empresários, pois estes, mesmo que fizessem o reajuste salarial dessa maneira (com empresário e assalariados "responsáveis" que teriam "chegado a compreensão global do problema" (DELFIM NETTO et al., 1965, p. 79) seriam engolidos pelos outros que fariam os reajustes de maneira como estavam sendo feitos.

Na palavras de Delfim:

o impulso para a industrialização passa a ser, nestes termos, um dos fins do próprio Estado (...) bem como por uma oportuna ação supletiva no campo da produção. Deve-se direcionar ao investimento, assim, as pressões inflacionárias inerentes ao processo de crescimento podem ser superadas pela existência de uma liderança política adequada, capaz não só de restringir o consumo global, como de reduzir a luta entre as diversas classes sociais pelo produto gerado pela economia (DELFIM NETTO et al., 1965, p. 10)

Ou seja, seria só com o Estado, e com uma "liderança política adequada" que se conseguiria "reduzir a luta entre as diversas classes sociais" pelo produto.

O Estado ainda é largamente estudado no Estudo Anpes 1, sobre a inflação, discutindo que era necessário rever a receita e despesas do governo. Os pontos centrais eram: i) melhoria do aparelho arrecadador de imposto; ii) aumento da produtividade do setor governamental. Na construção de infra-estrutura, na produtividade dos funcionários e, em

${ }^{195}$ Entrevista concedida (23/09/2013) para a realização do livro "Fipe: 40 anos" (SAES et al, 2014). 
especial, na "reduzida produtividade dos fatores empregados pelo Governo"; iii) ajuste dos preços das Sociedades de Economia Mista (aumentar as tarifas, "criar maior capacidade comercial"; aumentos salariais somente na proporção de aumentos de produtividades e tarifas; previdência em acordo com a contribuição; "eliminação do empreguismo"; redução dos gastos de administração; "melhoria do equipamento"; concursos e méritos dentro da carreira). Mas a adequação dos gastos do governo se poria muito difícil, pois "dentro de uma sociedade aberta como a nossa, o Governo poderá se furtar a continuar a prestar a enorme variedade de serviços que atualmente vem colocando à disposição da coletividade" (DELFIM NETTO et al., 1965, p. 143)

Comparando essa análise de Delfim, acha-se necessário cotejá-la com o trabalho de Sunkel sobre a inflação - citado por Delfim (et al., 1965) - e tido como um expoente da análise tida como Cepalina/Estruturalista. Para Sunkel, os componentes básicos de um programa de estabilização deveriam ser a ação nos principais "fronts inflacionários" (os fronts dos problemas estruturais), em primeiro lugar, a rigidez da oferta de bens. Estes se concentrariam em dois pontos essenciais: "produção de alimentos" e "aumento das exportações". Inclusive "El esfuerzo nitial de inversion debe realizarse en los sectores agropecuarios y de ex portation" (SUNKEL, 1958, p. 595). O foco no setor exportador parece "excepcional importancia" (SUNKEL, 1958, p. 595), dado que este permitiria superar a curto prazo; i) problemas de estrangulamentos existentes; ii) juntamente com a diversidade das exportações, diminuiria o problema da instabilidade do setor público; iii) o balanço de pagamentos; iv) o setor industrial.

Em segundo lugar, os problemas do sistema tributário. Uma reforma que eliminasse a inflexibildiade e regressividade e reorientasse os investimentos privados para a agricultura, exportação e outros setores básicos diminuindo os incentivos a bens de luxo.

Em terceiro, no "fronte dos problemas cumulativos", seria necessário; i) eliminar controles de preços à medida que os problemas de rigidez da oferta forem diminuindo; ii) aumento da produtividade. O próprio fim do sistema de controle de preços contribuiria para uma melhor alocação pelo mercado e eliminaria as empresas de pior qualidade iii) uma drástica reorganização do setor público. Converter em um eficaz servidor público, instituindo o mérito; iv) setor público em função de um programa de desenvolvimento. 
E, em quarto, no "fronte dos mecanismos de propagação", seria necessário; i) eliminar o défice fiscal; ii) reajustes de 'soldos e salários'; iii) reajustes de preços: a inflação proliferou muitas empresas ineficientes, com o fim da inflação, estas sumiriam.

No "fronte das pressões circunstanciais": "a única defensa que el país tiene contra las presiones inflacionarias circunstanciales es que haya conciencia de dichos fenómenos." (SUNKEL, 1958, p. 598).

Em relação ao que Sunkel chama de causas estruturais básicas: alimentos e gargalo importador. Como exposto, Delfim não nega que o setor produtor de alimentos possa gerar problemas de preços. Na verdade, quando analisada o setor da agricultura, ele deixa claro que era preciso voltar a investir na agricultura, levando crédito, assistência governamental, melhores infraestruturas e melhores condições de comércio ao agricultor. Inclusive Sùnkel propõe atitudes semelhantes para a agricultura chilena, no artigo ele nem chega a propor a reforma agrária como solução ${ }^{196}$. Delfim só não acha que é uma causa fundamental da inflação na economia brasileira, podendo-a, ser, em outro lugar. Contudo, ele não nega a possibilidade lógica de havê-la. Inclusive afirma que se houvesse uma inflação decorrente do "desequilíbrio persistente entre a oferta e a procura de alimentos" essa pressão levaria a um aumento de salários provocando novas emissões. "O aumento de preços provocam emissões e, portanto, aumentos nos meios de pagamentos" (DELFIM NETTO et al., 1965, p. 59). Contudo, ele não vê - ao obeservar a oferta e demanda de alimentos no Brasil - um descompasso persistente.

A segunda causa básica de Sunkel é o gargalo importador, algo que Delfim claramente vê como causa fundamental (e já se discutiu reiteradamente esse ponto). Os outros problemas, arrolados por Delfim (salário e défice público) também o são por Sunkel. Delfim nem parece realmente considerar o salário como causa fundamental, ao afirmar que "com relação ao reajustes salariais, deve-se reconhecer que decorrem, em grande parte, do próprio processo inflacionário (...) os reajustes salariais são a um tempo, causa e efeito da inflação, existindo um processo de auto-alimentação dos preços através dos salários” (DELFIM NETTO et al., 1965, p. 148). Dada a definição de Sunkel para o mecanismo de propagação:

En resumidas cuentas, el mecanismo de propagacion viene ser la capacidad de los diferentes sectores o grupos economicos y sociales para reajustar su

\footnotetext{
196 Apesar de afirmar que seria necessária uma mudança estrutural da agricultura para a resolução dos
} problemas. 
ingreso o gasto real relativo: los asalariados via los reajustes de sueldos, salarios y otros beneficios; los empresarios privados via las alzas de precios; $\mathrm{y}$ el sectorpublico via el aumento del gasto fiscal nominal (SUNKEL, 1958, p. 575 , grifos meus)

Não vemos muita diferença neste quesito entre os dois autores. Tudo parece indicar, então, que as diferenças de perspectivas económicas se apresentavam muito mais pelas diferenças da realidade que os autores indicavam observar. Aqueles que - baseados no trabalho de Sunkel - e tidos por "cepalinos", recomendariam a necessidade de reforma agrária, o faziam por perceberem não haver responsividade dos preços, e, dado que tudo o mais estaria evoluindo, a única possibilidade de mudança da agricultura seria, então, uma alteração de sua estrutura. Delfim não observa essa situação, e por isso, suas recomendações políticas são diferentes ${ }^{197}$. Mas tudo indica que os conceitos e a análise eram muito parecidos. A diferença não se daria, então, na construção do raciocínio, mas, por outro lado, na conexão entre o raciocínio e a realidade. Pode-se dizer que Delfim era tanto Cepalino, pelo razoamento, quanto não o era, dada as diferentes realidades as quais observavam. Isso também ficou claro, ao se discutir "industrialização orgânica" para Delfim. Para este autor, o impulso continuaria vindo de fora, e, a industrialização da década de 1950 não teria sido suficiente para superá-lo. Assim, nesta perspectiva, os autores (e.g. Furtado) que pleiteavam a necessidade de uma expansão maior do mercado interno como solução às crises deveriam considerar que a industrialização houvera sido orgânica nos termos de Delfim. Se esse estivesse sido o caso, Delfim - se mantivesse sua coerência - o mesmo propugnaria: expansão do mercado interno em detrimento de um esforço maior de exportação.

\footnotetext{
${ }^{197}$ Ressalta-se que, no nordeste, caso essa situação se confirmasse, Delfim a defende. Inclusive criticando o "direito natural" da propriedade privada, dizendo que este direito deveria estar subordinado ao desenvolvimento econômico.
} 


\section{Conclusão}

Esta dissertação abarcou o pensamento econômico de Delfim Netto, entre os anos de 1950 e 1967. Debruçou-se sobre os escritos produzidos por Delfim neste período, contextualizando-os com o momento econômico e histórico do país. Abordaram-se, no capítulo um, a formação de Delfim na faculdade e suas perspectivas metodológicas. Argumentou-se que Delfim fora formado em um momento de transição da economia, no qual disputavam e conviviam matérias e cursos diversos, os quais não tinham como bases fundamentais "livros textos" e abordavam diversas perspectivas da ciência econômica. Além disso, tudo indicou que seus maiores esforços foram aplicados para aprender e desenvolver os novos métodos estatísticos aplicados na economia. Toda essa bagagem plural - se não tenha determinado - caminhou na direção para formar um economista de difícil classificação, com similitudes e diferenças das diferentes escolas à época, que Delfim viria a se tornar. Sua metodologia era um esforço para fazer com que as observações da realidade moldassem a teoria, e não, que a teoria moldasse a realidade. Isso era uma maneira para Delfim combater a "teoria econômica clássica" a qual, para ele, atrasava o desenvolvimento em um país com o Brasil. No capítulo segundo, discutiram-se seus artigos publicados nos anos 1950. Nele destacaram-se três temas: o algodão, o comércio internacional e a inflação. No terceiro capítulo tratou-se da completude daqueles temas - em especial do algodão - sobre o café, este produto que sorvia os recursos da economia brasileira e mantinha uma elite atrasada, atravancando o desenvolvimento econômico brasileiro. No último capítulo, por fim, expôs-se a necessidade do planejamento para o capitalismo. Essa necessidade apareceu exatamente para impedir que uma minoria favorecida pusesse em xeque o desenvolvimento econômico no Brasil e para que se conseguisse colocar grilhões nas classes sociais - uma espécie de pacto imposto de cima - impedindo o que seria uma luta infrutífera pela renda, aumentando a proporção da renda em poupança e investimento (e, portanto, diminuindo a fatia destinada ao consumo presente), e direcionando a economia para a superação da restrição externa.

Assim que Delfim se forma, ele passa a ter uma atuação na BMSP, escrevendo artigos para a revista da instituição e lecionando um curso lá. Esses trabalhos também se compatibilizam com sua trajetória intelectual, uma vez que a principal mercadoria 
transacionada nesta Bolsa era o algodão, e assim, o autor já começa a expor a sua visão de mundo, ao entender a importância deste produto como alternativa ao café, e como fornecimento de matéria prima às manufaturas internas, retirando parte da dependência que estas tinham da importação do produto. Somente com a diversificação das exportações, em especial de bens industriais, poderia ser possível reverter a tendência ao desbalanço na relação de trocas entre países exportadores de produtos primários e países exportadores de bens industrializados.

Para Delfim, já nos anos 1950, percebe-se que este desequilíbrio estaria irmanado com o problema da inflação e da industrialização, não sendo possível discutir um sem se tratar do outro. Se por um lado, somente com a industrialização seria possível a superação do problema do desequilíbrio do comércio exterior, por outro, seria necessário à industrialização um câmbio barato, que a permitisse ser competitiva. Logo, o câmbio precisaria da indústria e a indústria precisaria do câmbio. Assim como para a inflação: um aumento dos preços levaria a uma valorização cambial, o que dificultaria a exportação e levaria um deslocamento de uma maior parte do comércio para importação, piorando o balanço comercial. Essa situação conduziria a um novo desequilíbrio, perdendo-se divisas, sendo necessária uma desvalorização do valor do câmbio, para se tentar encontrar algum equilíbrio a um preço mais desvalorizado do câmbio. A desvalorização, por sua vez, levaria a uma maior pressão nos aumentos de preços (ou seja, inflação), em especial em custo para as empresas e em custo para o assalariado. Em suma, a inflação levaria a uma maior depreciação, e uma depreciação levaria a uma maior inflação. Ainda, o próprio processo de industrialização - indispensável para o desenvolvimento brasileiro - levava a maiores custos ao se internalizar a produção aqui, o que trazia um aumento de preços; por outro lado, a inflação (mantido o câmbio fixo) fazia com que a industrias internas perdessem mercado. Assim, a industrialização se relacionava com a inflação (pois aumentavam-se os preços com o processo de ISI), e esta, com a industrialização (ao fazêla perder mercado interno e dificultar a exportação de seus produtos). Também, o próprio processo de industrialização por substituição de importações pressionava ainda mais o balanço de pagamentos - tornando-o mais rígido e mais dependente de importações intensificando o défice, o que pressionaria ainda mais o câmbio.

Todas essas variáveis, ainda, influenciavam cada grupo social de maneira diversa e eram por eles influenciadas. Dessa maneira, Delfim entendia que como forma de acomodar as diferentes visões, o governo cedia; ora agradando uns, ora agradando outros, 
“desregulando a todos". O governo de JK é o mais é evidenciado pelo autor nesse sentido, mas esse processo teria sempre ocorrido na história do Brasil, e na verdade, seria uma variante constante no "capitalismo liberal", cujo discurso de livre mercado seria apenas uma ideologia para a manutenção dos privilégios de alguns poucos. $\mathrm{O}$ exemplo mais claro desse processo, na história do Brasil, fora a elite cafeeira que - com o discurso de identificação do problema do café com o problema do povo brasileiro - teria controlado a política econômica brasileira por quase um século, subjugando-a a seus interesses. A não ser em um período muito específico da história do Brasil: no primeiro governo Getúlio Vargas, o qual, como sendo um "governo de força", haveria colocado grilhões nesta elite, conduzindo a economia aos interesses da coletividade. Essa compreensão é muito importante para o entendimento da cosmovisão de Delfim, pois para o autor, o governo representando a sociedade deveria comandar a economia, e não, como ocorria, então, na qual alguns grupos comandavam-na, porque possuiriam capacidade de organização, impondo ao resto da sociedade as suas demandas.

De certa forma, seria como se o "mercado" político não funcionasse de maneira concorrencial, na qual todos teriam possibilidades iguais de expor suas prerrogativas e pensamentos; mas ao contrário, seria um "mercado" altamente concentrado, na qual os privilegiados dominavam a economia com as suas vontades. Fossem eles empresários, ou assalariados organizados. A questão não perpassa o aspecto da moralidade de cada grupo, e, por isso, caberia a "pessoas interessadas no desenvolvimento econômico" regularem como este deveria ser conduzido. Não se empenha em explicar como seria possível que em uma sociedade dominada por uma menoridade venha a ter um governo que não a represente exclusivamente. Contudo, acredita que o desenvolvimento econômico é o desejo da coletividade, pois só este poderia permitir maiores avanços sociais - fossem maiores padrões de vida, fosse maior tempo de lazer - e o estabelecimento de uma sociedade que menos dependesse de formas de relações atrasadas. De certa maneira, então, para Delfim, o "governo de força" de Getúlio Vargas fora muito mais "democrático" do que, e.g., o governo de JK, o qual, para ele, estaria servindo a uma minoria, enquanto, aquele, retirou o poder da elite cafeeira e orientou a economia ao desenvolvimento econômico.

Claramente, não faria sentido encaixar Delfim em uma perspectiva comunista. Ele é um grande defensor do capitalismo, acreditando nas possibilidades de avanço e mudança que este poderia trazer ao Brasil. Nesse sentido, ele seria, realmente, o grande inimigo 
daqueles que pleiteavam a revolução como única saída a continuidade do desenvolvimento econômico no Brasil. Sua defesa ao planejamento deve ser necessariamente vista sob essa ótica: um defensor do capitalismo. O que não significa que ele não visse dificuldades neste sistema, e por isso sua tentativa de consertá-lo era, dessa maneira, "concertá-lo". A sua visão de comunismo parecia muito com a do capitalismo liberal: uma minoria subjugando a maioria. No capitalismo por meio da economia, e, no comunismo, por meio da força. Novamente, dentro dessa chave de leitura, um governo como fora o de Getúlio Vargas (1930-45) haveria permitido muito mais liberdades do que em outros governos tidos como "democráticos", tais como o de JK. De certa maneira, a inflação poderia ser entendida também como falta de um governo (que não tomasse partido) na orquestração da economia. Porque, não havendo incentivos para os empresários investirem, a capacidade destes em aumentarem os preços de seus produtos, criava o incentivo fundamental para o investimento. Contudo, havia uma reação por parte de grupos da sociedade, para recuperar a parte da renda perdida, elevando o salário. Todo esse complexo sistema, ainda, afetava e era afetado pelas mais diversas variáveis.

Este complexo exigia, portanto, um entendimento para que se pudesse diagnosticá-lo e, só daí, agir. A "ciência econômica” era vista como necessariamente uma ciência ativa, cujo significado só existiria se dialogasse com a realidade com a finalidade de transformála. E o objetivo dessa transformação deveria ser a mudança de estruturas caracterizada como o próprio desenvolvimento econômico. Industrialização, urbanização e maior aumento da produtividade do campo, estas eram as grandes bases para o desenvolvimento econômico. Sem elas, não haveria aumento de renda que pudesse ser considerado desenvolvimento econômico. O Brasil, contudo, passava por um momento singular à época: a industrialização que houvera não fora orgânica, i.e., a economia brasileira ainda dependia do estímulo externo para se desenvolver. Essa falta de organicidade da industrialização exigiria, ainda, muita importação para se internalizar as estruturas produtivas até o nível suficiente que estas se tornassem o principal estímulo da economia. Antes disso, contudo, não se poderia discutir desenvolvimento sem a superação do maior gargalo da economia: o setor externo. Não haveria, portanto, uma troca entre privilegiar o mercado interno ou o externo; haveria apenas uma troca entre desenvolver aumentando as exportações (e as diversificando) ou estagnar. 
Todos esses alicerces no pensamento de Delfim (necessidade de industrialização, de planejamento, de aumento da produtividade no campo, de tendência ao desequilíbrio externo) o colocariam muito mais perto de um escopo "Cepalino" do que possivelmente de um escopo "Gudiniano" no Brasil. Todavia, não se passa dessa forma. Delfim faz um esforço consciente de se afastar daquela escola. Tudo pareceu indicar que o método de Delfim se aproximava muito mais daquele defendido pela Cepal - a necessidade de contextualizar e historicizar - o desenvolvimento. Esse, inclusive, é um dos argumentos para Delfim dizer que não há necessidade de reforma agrária no desenvolvimento brasileiro, porque cada país encontrou uma maneira diferente de se desenvolver, não havendo determinismos. A grande diferença parece ser na realidade que eles observam: a Cepal descreve uma realidade com uma estrutura agrária ultrapassada no campo, e, portanto, os lucros seriam retidos pelos "latifundiários" sem um reinvestimento necessário na produção. Já, Delfim, não observa isso. Ele observa empresários no campo com atividades bastante incertas, cujos ganhos de produtividade estariam sendo retidos pelo oligopólio no comércio. Houve crescimento dos produtos agrícolas, sendo o maior problema destes o café que lhes roubava espaço. Para a Cepal, a solução seria a reforma agrária. Para Delfim, maiores créditos e melhores escoamentos para a produção e planejamentos do governo.

Para ambos, a indústria precisaria de mercado para se poder desenvolver, ambos observavam a falta de mercado para indústria. Contudo, como Delfim não observa uma “industrialização orgânica" no país, haveria, ainda, uma dependência da importação para o desenvolvimento, e, portanto, do mercado externo. Para este, então, a solução seria aumento da exportação e não, somente, aumento do mercado interno. O mercado interno deveria ser um mercado "de massas" o qual só seria conseguido aumentando-se ainda mais a urbanização/industrialização, o que só seria possível com aumento da produtividade no campo e dos empregos na cidade criados com a maior industrialização. A maior produtividade no campo e na indústria de bens de consumo permitiria uma maior competitividade do Brasil como um todo, havendo uma espécie de ganhos em rede (sinergia positiva); quanto mais se industrializasse/urbanizasse a economia, mais produtiva ela se tornaria. Por outro lado, o próprio desenvolvimento criaria problemas, exigindo investimentos (em saúde, educação, infraestruturas etc.) com menor retorno para quem os fizesse, funcionando como uma espécie de freio à economia, os quais caberiam 
ao governo realizar. Todas essas situações estariam longe de serem resolvidas pelo mercado, o que serviria para aproximá-lo, novamente, mais ao lado da Cepal.

Não se espera haver esgotado o assunto. Seria interessante a continuidade dessa pesquisa, cotejando Delfim enquanto intelectual - interpretando a realidade e lhe propondo soluções - com a sua atuação no governo durante o período do "Milagre Econômico". Tudo parece indicar, todavia, que as duas estão em harmonia, não havendo grandes divergências entre elas. Ainda, seria possível uma reavaliação sobre o debate de concentração de renda desse período (que emergiu, após o censo de 1970), a qual é apresentada como a grande pedra de toque das críticas a Delfim e ao "Milagre". Seria interessante reinterpreta-lo à luz do pensamento de Delfim, o qual de maneira alguma advoga a inevitabilidade da concentração de renda para o maior desenvolvimento. Por fim, que alguém reveja suas visões sobre a necessidade de aumento da exportação (de produtos com cada vez maior valor agregado) para a continuidade do desenvolvimento brasileiro. 


\section{Anexo I-Programas Econômicos:}

1. Programa de Metas/Plano Trienal/ Programa Econômico do Desenvolvimento (PED)/ $1^{\circ}$ Plano Nacional de Desenvolvimento/ $2^{\circ}$ Plano Nacional de Desenvolvimento.

\section{PROGRAMA DE METAS DO PRESIDENTE JUSCELINO KUBITSCHEK}

ESTADO DO PLANO DE DESENVOLVIMENTO

ECONOMICO EM 30 DE JUNHO DE 1968. 


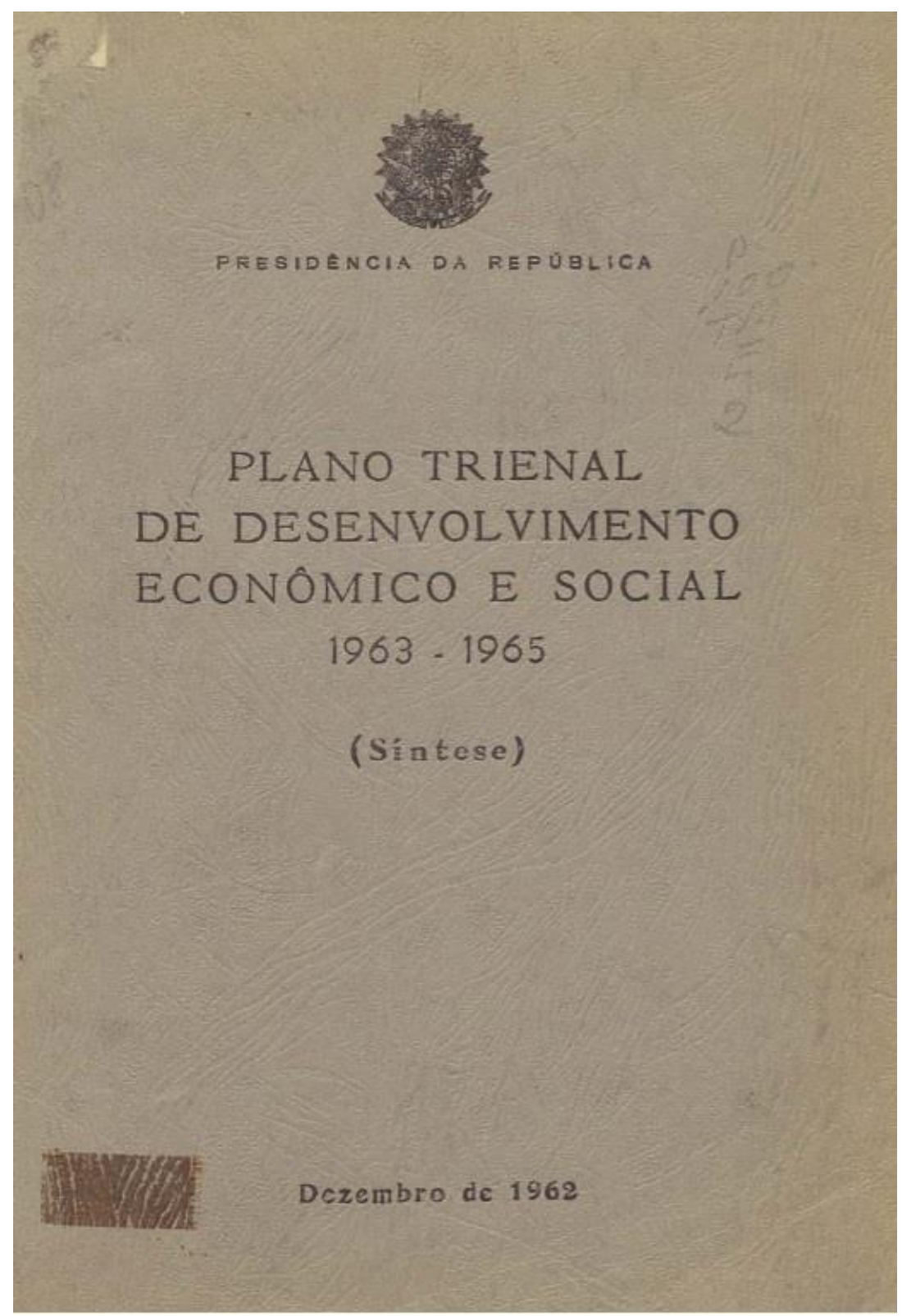


MINISTÉRIO DO PLANEJAMENTO

E COORDENAÇÃO GERAL

\section{DIRETRIZES DE GOVÊRNO \\ PROGRAMA ESTRATÉGICO \\ DE DESENVOLVIMENTO}

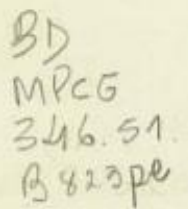

JULHO · 1967 


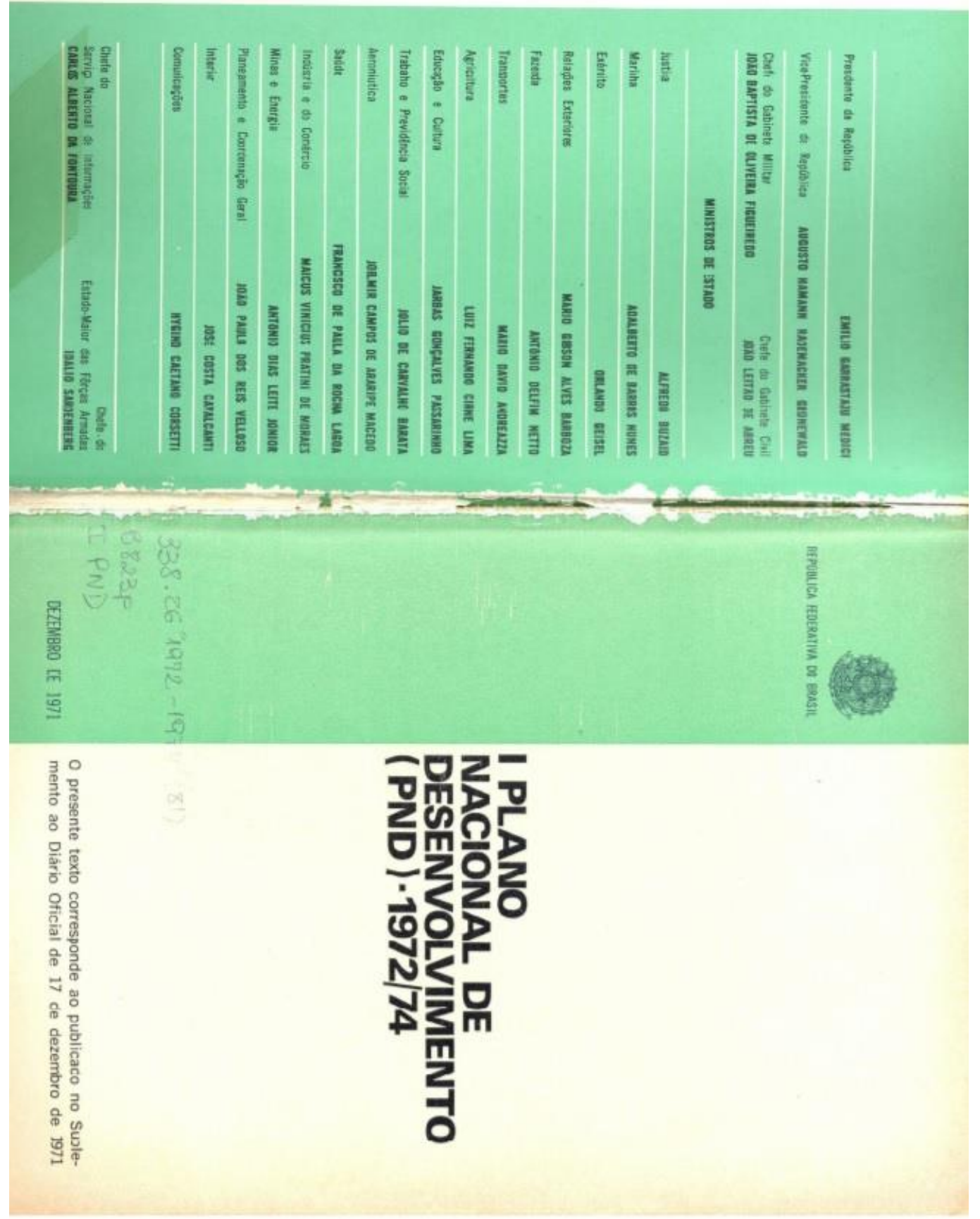




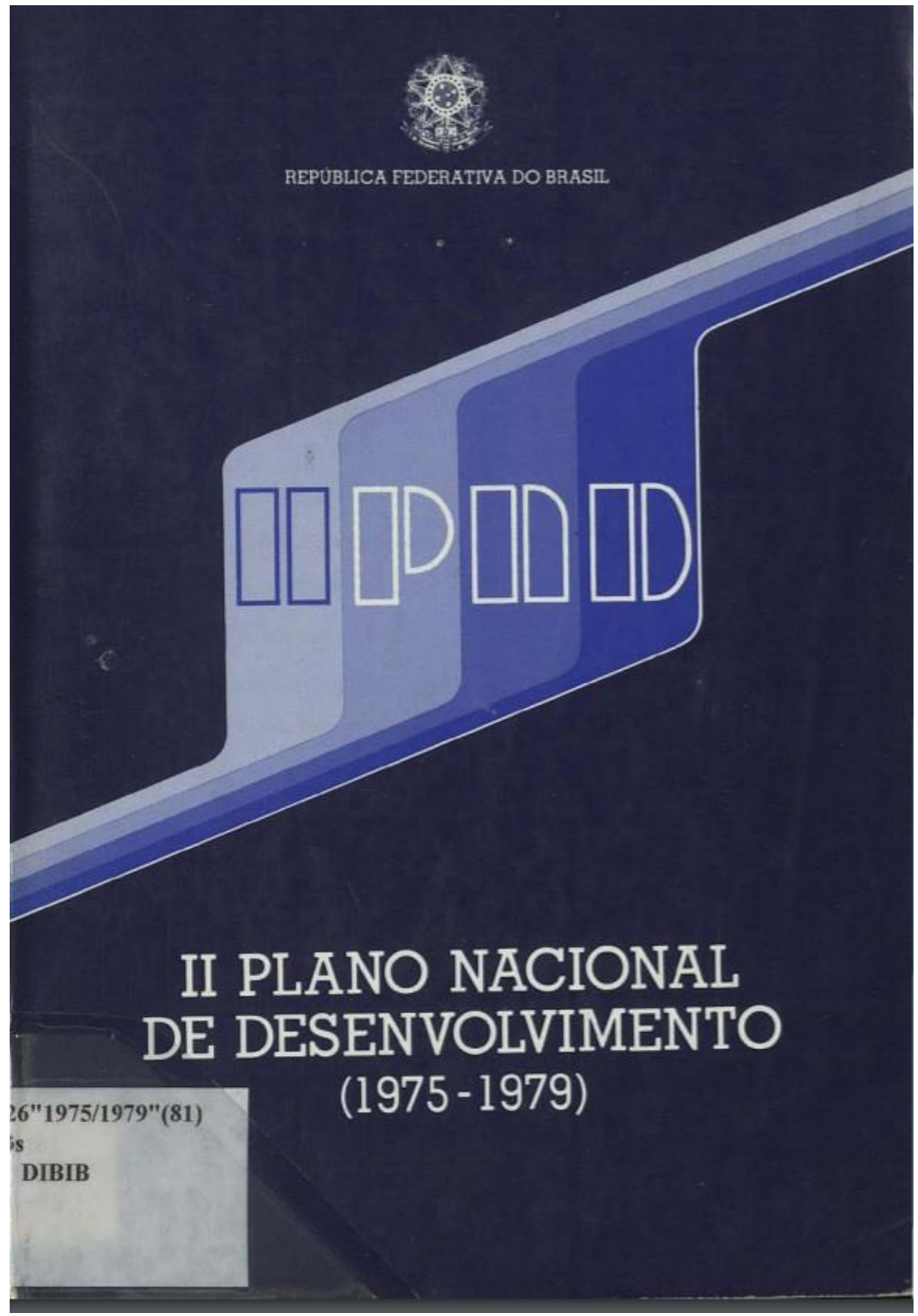

2. Planejamento de Reforma Agrária no primeiro governo militar (1964-67) 


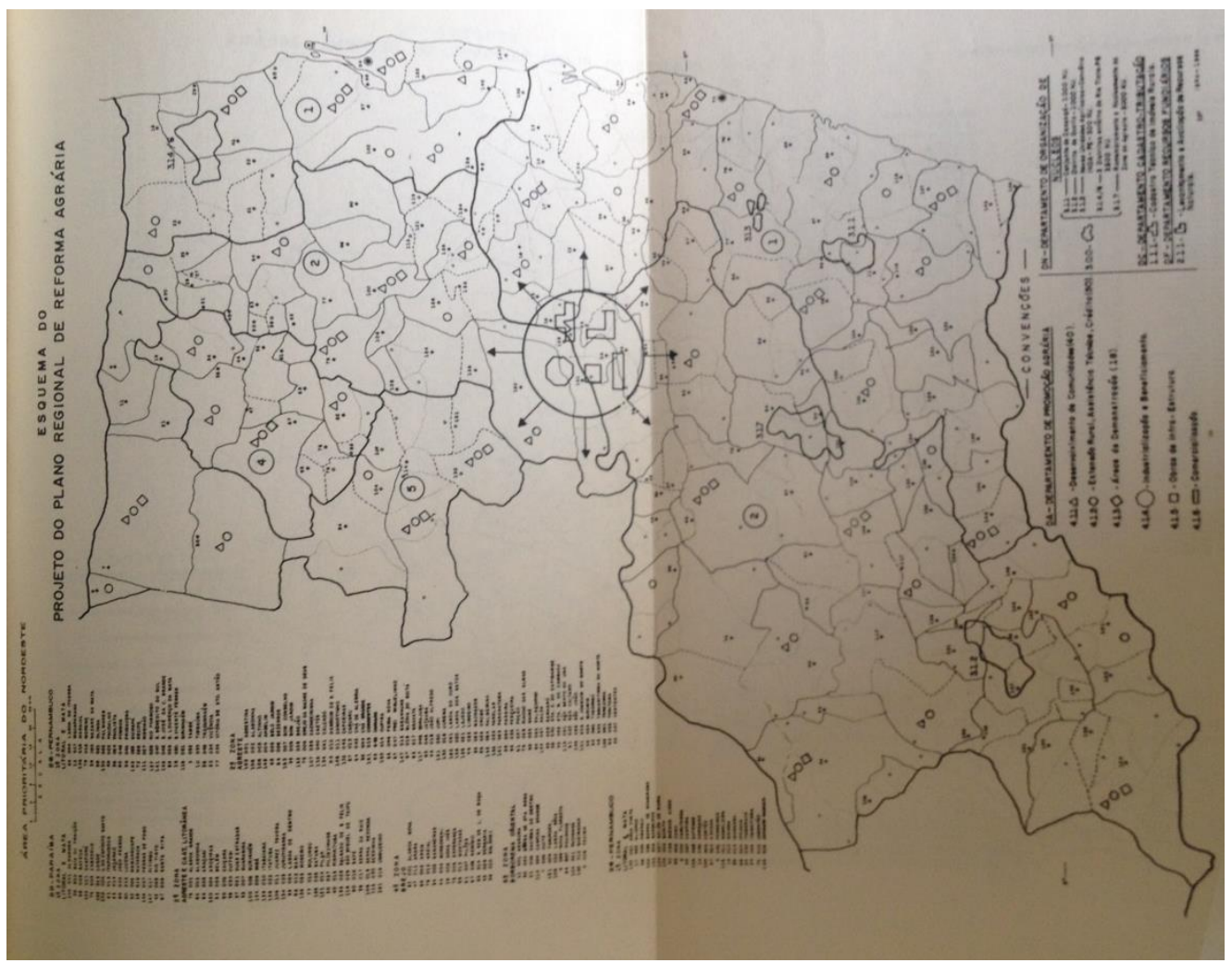

Focos de Reforma Agrária a serem postos em prática nas "áreas prioritárias do NE"

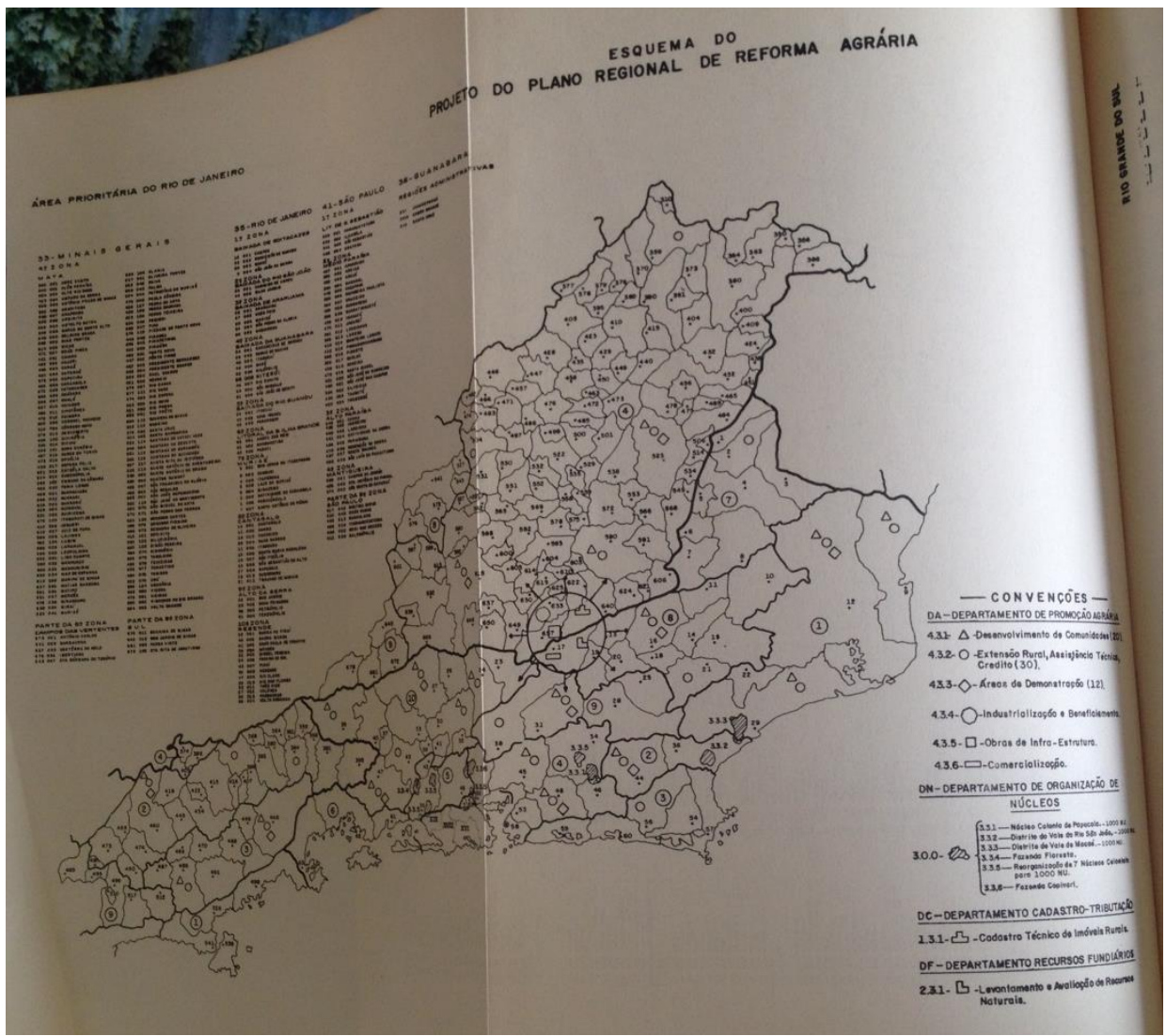

Focos de reforma agrária a serem postos em prática no $\mathbf{R J}$ 


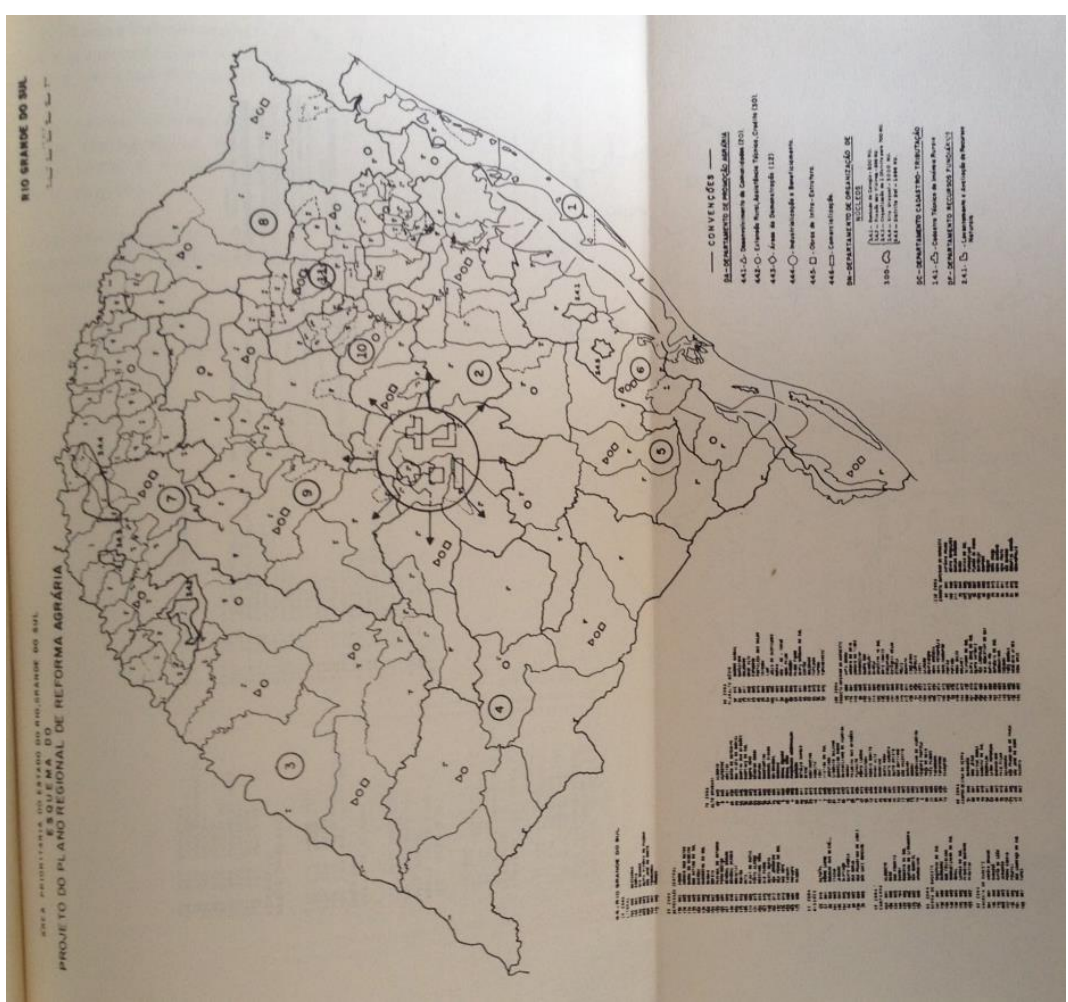

Focos de reforma agrária a serem postos em práticas no RS 


\section{Anexo II: Roteiro de Leitura do Livro "O Problema do Café no Brasil"}

Este anexo é apenas um roteiro de leitura do livro "O Problema do Café no Brasil" que serviu ao autor dessa dissertação a organizar suas ideias para poder escrevê-la. Em especial, o capítulo 3 deste presente trabalho teve origem nesse roteiro. Espera-se que ele possa ser útil, e por isso optou-se por manter junto ao trabalho.

\section{O Problema do Café no Brasil}

Em 1959, Delfim apresenta, como tese de livre-docência, O Problema do Café no Brasil $^{198}$. Obra extraordinária que pode ser (e neste trabalho será) dividida em duas, apenas para fins de compreensão e crítica. O que se pode chamar de primeira parte, compreendendo os capítulos um (à exceção da introdução) ao quatro, seis, nove, dez e onze, utiliza-se de uma metodológica mais "histórica" do café: as políticas domésticas e forâneas a respeito da rubiácea, e seus respectivos impactos, de curto ao longo prazo. Sua conclusão mais conhecida (mas longe de única) permeia quase todas as seções desses capítulos, qual seja: as políticas de café não deveriam ser pensadas apenas para o curto prazo, e sim, o longo. De forma a maximizar a receita proveniente da exportação no longo prazo. Uma outra parte, a qual se utiliza de uma metodologia com formalização matemática e de seu instrumental; nela, podem-se incluir os capítulos cinco, sete, oito e a introdução do capítulo primeiro. Não seria exagero entender o livro com tendo uma parte de história econômica e, uma outra, de aplicação de métodos matemáticos/estatísticos. Obviamente que essa divisão é artificial, cabendo-a, apenas, para uma análise da obra.

Primeiro, então, separemos os argumentos de Delfim entre aqueles que trazem à tona o instrumental matemático, e entre aqueles que são construídos na linguagem vernácula ordinária. Dos capítulos 1 a 4 é feita uma análise detalhada, por vezes enfadonha, contudo, necessária ao trabalho que se pretende ao público acadêmico, pois muitas das hipóteses por trás do texto são sutis, o que exige uma escavação mais profunda para se poder trazêlas à tona e permitir, assim, a boa exegese e a construção do argumento do presente trabalho.

Estes quatros capítulos são bastante descritivos, construindo uma narrativa a respeito da cultura cafeeira no Brasil. O capítulo um se ocupa de descrever o mercado do café antes da intervenção governamental (1857-1906); o capítulo segundo, com defesa esporádica

${ }^{198}$ DELFIM NETTO, Antonio. O problema do café no Brasil. São Paulo: FEA-USP, 1959. 
do café (1906-1924); o terceiro, da defesa permanente deste produto de 1924, até a safra de 1956/59, momento contíguo ao da tese de Delfim; cabendo, ao quarto, a discussão do aumento da oferta de café pela Colômbia e África.

O capítulo 5 modela uma curva de oferta e outra de demanda e se ensaia chegar a um equilíbrio a partir destas. Conclui-se que o mercado de café é inerentemente instável, fosse com intervenção, fosse sem. O sexto capítulo resvala no anterior. Relaciona o problema do café (exposto no capítulo antecedente como inerente à rubiácea) ao caso específico (e mais complexo) do mercado brasileiro. Neste capítulo é onde a relação do café com a indústria fica mais clara, no pensamento de Delfim. Apesar de a queima do café nos anos 1930 ter sido um mal necessário, a sua continuação como política foi extremamente danosa à economia como um todo, em especial por retirar recursos da indústria. O capítulo sétimo, assim como no capítulo quinto, é feito um modelo para se tentar simplificar o problema do equilíbrio no mercado cafeeiro. É dividido em três subpartes: o "equilíbrio do mercado dentro da política de valorização"; "o equilíbrio do mercado dentro da política recente"; e, "o custo social da defesa". Neste capítulo, a conclusão de que o Brasil deva parar de agir como maximizador da receita no curto prazo, ao invés de no longo, é formalizada. Por fim, formaliza um modelo no qual explicita uma situação de comércio internacional na qual a política de livre-cambismo é pior do que a de algum protecionismo, o que mesmo assim não advogaria em favor da defesa. No capítulo oitavo, vê-se um esforço grande de Delfim para combater a ideia de que a oferta do café poderia ser tomada como inelástica ao se delinear as políticas econômicas. Apesar de verdade no curto prazo, ela não a é, no longo. É o capítulo que mais se traz referências aos métodos de estatística mais recentemente, então, desenvolvidas. Seria o mais próximo da "fronteira" daquele assunto. Mesmo assim, Delfim não encontraria na estatística todo o arcabouço suficiente para conseguir arguir seu ponto. No capítulo nono, são discutidos os acordos internacionais, concluindo-se que os acordos sempre haviam sido ruins na perspectiva brasileira, e que o Brasil só deveria entrar em um, caso houvesse claros benefícios ao país. No capítulo décimo, discute-se a possibilidade que o Brasil tem de expandir a fronteira dos consumidores de café ao redor do mundo, buscando novos países clientes.

\section{Capítulo 1: o mercado cafeeiro sem a intervenção governamental}

No primeiro capítulo, Delfim analisa o mercado cafeeiro de meados do século XIX (1856/57) até o começo do século XX (1904/05), antes do convênio de Taubaté. Seria 
importante esta análise para se tentar compreender como se regulava o preço antes das intervenções governamentais brasileiras; ou seja, tentar analisar como se regulava o "livre-mercado" do café. Assim, posteriormente, poder compará-lo com o período das intervenções (sejam elas esporádicas, ou permanentes).

Este capítulo é o mais claramente dividido no método: a introdução se utiliza de métodos econométricos - juntamente aos dados - para se procurar por alguma tendência ou oscilação no preço do café, nestes anos de pré-Convenio de Taubaté. No restante, que representa a maior parte do capítulo, é descrito historicamente as nuances do mercado do café durante este mesmo período.

Quanto à parte estatística introdutória, os dados analisados são o preço médio de importação do café nos Estados Unidos ${ }^{199}$, i.e., dividindo-se o pagamento total em dólares pelo volume de café importado. A amostra começa a partir de 1857, e essa escolha, Delfim a justifica:

A escolha é evidentemente arbitrária e justifica-se pelo nosso desejo de examinar um século dos preços do café, em cuja primeira metade o mercado foi interamente livre e em cuja segunda metade registram-se intervenções de toda a sorte (DELFIM NETTO, [1959] 2009, p.12).

Além disso, Delfim diz que se baseando nos estudos de Thurber (1881), ele havia se convencido de que "1857 marca o início do período de ascensão de um ciclo do mercado cafeeiro" (DELFIM NETTO, [1959]2009, pp.12-13). Ao se justificar a periodicidade de sua amostra, já a enviesa - em certo sentido - ao começá-la por um período de ascensão cíclica.

Uma crítica feita ao Delfim é justamente questionar a escolha do período de análise. Nesse sentido, advogou-se que teria sido melhor para se entender o mercado de café do período se fossem escolhidos os anos de 1845-1895, e, ao não se o fazer, Delfim “desconsidera a tendência secular desses preços" (BACHA, 1992, p. 24). Dessa forma, se é verdade que Delfim escolhe um período propício para observar ciclos e não tendência (dado que, como ele mesmo admite, parte de um começo de um ciclo), esta crítica o faz para se observar tendência. Uma réplica cabível ao argumento deste autor é que os anos de 1895 até 1906

\footnotetext{
${ }^{199}$ Edmar Bacha se concentrará nesse ponto para criticar alguma das conclusões de Delfim; dirá que os preços nos EUA estavam passando por um período de deflação, e que por isso havia sim, já, uma tendência crescente no preço do café. Esse assunto será tratado mais para frente. "Quando se leva em conta a deflação dos preços em dólares depois da Guerra Civil Americana, a tendência ascendente dos preços do café tornase manifesta - veja-se o Gráfico 2 - e reafirma-se como sendo o impulso fundamental para a expansão do cultivo do café no Brasil e em outros países americanos.” (BACHA, 1992, p.24).
} 
são relevantes e não deveriam ser deixados fora da amostra, pois 1906 é o ano da primeira intervenção (causada pela expectativa de uma safra de tamanhos sem precedentes). Inclusive, porque os preços internacionais do café são bastante cadentes a partir de 1895 . Assim, se se pode observar uma tendência ascendente no período de 1840-1895 é igualmente verdadeiro que não a há, em um período diferente, que inclui os anos de 1895 até 1906, ano da primeira intervenção realizada no mercado cafeeiro.

Pelos testes, Delfim conclui que antes da interferência no mercado, este não apresentava tendência secular e que há indicações de haver um movimento oscilatório (em outras palavras, rejeita-se a "hipótese nula de que os preços se comportavam como uma variável aleatória"). Estes dois resultados estão em linha com o esperado de Delfim; o primeiro, por indicar que não havia uma tendência no preço do café; e o segundo, o de indicar que o preço do café do atual momento é influenciado pelo preço do café de períodos passados, pois o

cafeeiro é uma planta perene que apenas produz completamente no seu $4^{\circ}$ ou $5^{\circ}$ ano de vida e, depois disso, continua produzindo economicamente durante (...) 15 ou 20 [anos até] (...) 50 ou 60 anos, em áreas excepcionais (DELFIM NETTO, [1959] 2009, pp.16-17).

Tendo utilizado de testes econométricos para corroborar a ideia de não se haver tido uma tendência secular dos preços, de que eles eram formados por preços passados e, explicado essa tendência por uma generalização do modelo de Teia de Aranha, a introdução termina, e passa - sem se utilizar de nenhum teste estatístico/econométrico - a analisar aquilo que chama de três ciclos dos preços. O primeiro entre 1857-68; o segundo de 186985 ; e, finalmente, $1886-1906 .^{200}$

\footnotetext{
${ }^{200}$ Em 1857, Delfim justifica a subida de preço nesse período por dois motivos: a recuperação da economia europeia e à infestação das culturas cafeeiras do Brasil pela elachista coffeela. Já em 1864, no início da guerra do Paraguai, os preços já se encontravam em queda, pelo grande aumento da oferta (brasileira e a maior produção na América Central, Ásia e África) e a queda de demanda dos EUA, devido à guerra civil. Em 1866, deu-se início na Europa, em especial na Inglaterra e na França, uma crise econômica. A queda nos preços do café, para o autor, é reflexo desta. Este primeiro ciclo, é, para Delfim, uma evidência de como o sistema de preços haviam funcionados corretamente, com os preços internos baixando juntamente com os externos. Contudo essa baixa de preços fosse insuficiente para desestimular as novas plantações no interior paulista, pois o desenvolvimento das estradas de ferro diminuíram os custos. No segundo-ciclo, em 1869, o preço voltou a subir devido a uma quebra generalizada da safra, tanto no Brasil quanto na América Central. Esse novo ciclo de expansão seria impulsionado, ainda, por uma geada que destruira parte considerável da produção paulista, elevando o preço até 1874. A partir desta data, contudo, o preço interno do café caiu lentamente, pois a queda externa foi acompanhada pela queda do câmbio, e por isso, em parte, compensando a perda em moeda nacional. E assim, incentivou-se o aumento da oferta, e, com esta, as exportações aumentaram, conseguindo manter - e até majorar - a entrada de divisas. O terceiro ciclo, analisado a partir de 1886, tem a sua ascensão de preços explicada, pelo autor, devido às grandes flutuações da oferta, causadas pelo próprio ciclo do cafeeiro. Somado a isso, o fim da escravidão havia posto em trilho uma maior necessidade de dinheiro líquido. Essa carência de numerário permitiu que as grandes casas de
} 
Um ponto que vale chamar atenção é da data de 1894, período de inflexão do terceiro ciclo. Para Delfim, com a queda dos preços internacionais - pela crise europeia e norteamericana - o café não conseguiu, pela primeira vez, manter a entrada de divisas pelo aumento compensatório da exportação. Levando assim, a "gênese do problema cafeeiro nacional": a queda dos preços externos foi suplantada pela queda mais rápida do cambio, dando estímulos para a produção interna do café, mesmo em momento depressivo do mercado. Esta queda do câmbio, além da diminuição de divisas, foi acentuada pela inflação decorrente do "encilhamento" ${ }^{201}$. E, mesmo assim, toda essa flutuação se deu pela:

Crença irrestrita no sistema de preços para regular a economia que vigorava naquele período. Se existissem dúvidas sobre a eficiência desse mecanismo, não teriam sido permitidas as flutuações de preços verificadas dentro de cada ciclo. (em média, os preços mínimos do ciclo representam menos do que a metade dos preços máximos) e desde cedo teríamos encontrado tentativas de estabilizar em algum ponto a receita de divisas do país." 202

Dessa forma, de nada adiantou a crença no livre-mercado, teria sido melhor a dúvida, a qual abriria espaço para se tentar minorar as "flutuações de preços verificadas dentro de cada ciclo". A convicção no sistema de preços fora uma das responsáveis por uma crise sem precedentes no café e na economia cafeeira. Ademais, Delfim ajunta uma variável: as políticas de expansão monetária do encilhamento contribuíram para esse cenário. Delfim elogia Murtinho, que manteve as finanças do governo saneadas, e acreditava que se havia um excesso de oferta, o mercado iria tratar de eliminar os produtores mais ineficientes. A essa política, Delfim elogia, ressaltando que os fatores de produção existentes não desapareceriam, mas sim migrariam para outras atividades.

Ninguém desejava entender o fato de que a ruína dos fazendeiros simplesmente transferiria as suas propriedades para outros empresários, como Calógeras acentuaria mais tarde, mas que o rendimento nacional (...), continuaria exatamente o mesmo (Delfim Netto, [1959] 2009, p.46).

\footnotetext{
exportação - geralmente estrangeiras - de café conseguissem espremer ainda mais a margem do comissário (e, consequentemente, do cafeicultor).

${ }^{201}$ Outros dois fatores são elencados por Delfim: o fato de a economia de subsistência ter sido quase que completamente abandonada após a libertação dos escravos, sendo necessário, assim, importar bens antes dessa maneira produzidos; e, uma revolta da esquadra, de 1893, que desorganizou o comércio de cabotagem, imprimindo a São Paulo a necessidade de recorrer ao exterior para importar cereais. Delfim, 2009 , p.32.

${ }^{202}$ Delfim Netto, [1959] 2009, p.44
} 
Por outro lado, além dos ditames da economia nacional, o café estava sujeito à lógica especulativa, que explicava a grande oscilação das exportações brasileiras. Esse comportamento especulativo gerava grandes desestabilidades, e "pode deixar de funcionar justamente no momento em que se torna mais necessário" (DELFIM NETTO, [1959] 2009, p.57). Assim, o problema do café:

não se resolveria dentro de um economia de mercado. (...) É possível, (...), que o peso da oferta reduzisse de tal maneira o preço interno do café, que o rendimento obtido com o produto fosse insuficiente para cobrir as despesas de custeio, mesmo das culturas mais produtivas, o que poderia representar a eliminação completa da cafeicultura nacional (DELFIM NETTO, [1959] 2009, p.57)

Pois,

O mercado cafeeiro era então, como é hoje, dominado pelo comportamento de algumas grandes empresas torradoras, que funcionam como condutoras de um oligopólio. Dada a magnitude de seus estoques e o volume de seus recursos financeiros, essas empresas praticamente determinam o andamento do mercado e seus movimentos são imitados por grande número de pequenos improtadores e improtadores-torradores (DELFIM NETTO, [1959] 2009, p.42)

Portanto, os especuladores - trabalhando em cima expectativas - deveriam ser sempre levados em consideração, pois eram quem realmente dominava o mercado. E, foram eles, em parte, os responsáveis pelo aumento dos preços a partir de 1902, levando a uma safra “de volume até então desconhecido" em 1906/07. E, estes mesmos especuladores poderiam ser culpados de destruir plantações sadias e produtivas. Assim, se brevemente Delfim elogia Murtinho que tentou manter as finanças do governo "sadias", ele critica quem cria (como parece ser o caso do Murtinho) no sistema irrestrito de preços. E, caso não se abrisse exceções ao "expansionismo" mesmo as culturas mais produtivas teriam ido à bancarrota.

A esta interpretação de Delfim, foram-se feitas algumas críticas. A primeira (discutida no começo dessa seção) é a de que na verdade existiria sim uma tendência ao aumento dos preços no século XIX, e de que não seria somente um movimento oscilatório, como o quer Delfim. Neste ponto, é interessante retomar a análise de Bacha, quando este diz:

(...)a segunda metade do século XIX esteve marcada por movimentos cíclicos significativos, numa alternância de mercados vendedores e compradores, (...). Não obstante, a tendência dos preços do café é claramente ascendente entre o final da década de 1840 e os primeiros anos da década de 1890 (BACHA, 1992, p. 21) 
Dessa maneira, voltamos ao ponto: os dois autores concordam com a análise do século XIX por movimentos cíclicos. Contudo, enquanto um se foca em um momento que há uma tendência de aumento de preços no mercado, o outro se concentra em um período no qual a oferta - mesmo que tardiamente - recupera-se do descompasso, mas consegue atingir a demanda, suplantando-a, em muito, em 1906. Com certeza, esse impasse não pode ser resolvido por métodos econométricos, nem mesmo por alguma aplicação mais "neutra da ciência".

A segunda crítica é sobre quanto a política do "encilhamento" teria realmente desregulado a produção de café.

Para alguns autores, o aumento da base monetária não teria afetado significativamente a “sobreexpansão da produção paulista de café no início da década de 1890" a qual teria sido "liderada (...)pelo significativo aumento dos preços reais do café em moeda estrangeira que se manifesta desde o princípio da década de 1880” (BACHA, 1992, p.27)

Explanaremos melhor este ponto de Delfim. Este afirma que a produção foi estável na década de 1880. Diz ele: "Desde 1880, época em que se tornaram adultos praticamente todos os cafezais plantados sob o estímulo da alta de preços de 1868 a 1874, até 1890, nossa produção permaneceu mais ou menos no mesmo nível” (DELFIM NETTO, [1959] 2009, pp.30-31)

Agora, não nega que o aumento dos preços externos de fins da década de 1880 tenha contribuído para o aumento da produção em 1890, apenas afirma que é muito difícil dissocia-lo do estímulo dado pelo aumento da remuneração em divisas internas:

(...)verificamos que o aumento substancial da remuneração em moeda nacional se verificou em 1887, onde uma pequena exportação (devido a uma grande redução da colheita) não foi suficientemente compensada pela elevação dos preços externo e a receita total de divisas proveniente do produto caiu. O câmbio reagiu desfavoravelmente e os preços em moeda nacional subiram mais (quase 60\%) do que os preços internacionais (cerca de 30\%). Os café plantados nesse ano (e, evidentemente, os plantados em 1886, quando o aumento de preço foi de apenas 11\%) tornaram-se adultos em 1891 (DELFIM NETTO, [1959] 2009, p.31, grifos meus)

Assim, podemos ver que Delfim reconhece que houve aumentos de preços externos na década de 1880. A questão fundamental é que o sistema de preços internos tinha um papel também necessário na determinação da alocação dos recursos internos. Papel este que parece não ter espaço na análise de Bacha. Contudo, é a partir da queda dos preços em 
1894 (a qual Bacha atesta que houve, fosse em termos reais, fosse nominais) que Delfim afirma que as exportações de café não haviam sido suficientes para manterem o cambio cadente acompanhando o ritmo dos preços internacionais do café, mas a desvalorização havia sido maior.

Continua Bacha sobre a asserção de Delfim: “(...)a substancial desvalorização cambial que o país experimentou no início da década de 1890, causada principalmente pelos excessos de expansão monetária que acompanharam a queda da Monarquia (...)" (BACHA, 1992, p.25, grifos meus)

Delfim deixa claro que esta desvalorização é causada por vários motivos, sendo o principal o balanço de pagamentos: tanto a exportação de café que não é suficiente, quanto o trabalho livre (com a liberação dos escravos, abandonando-se boa parte da cultura de subsistência, e a vinda de imigrantes). Por este último, fez-se então presente a necessidade de compra monetária de bens antes produzidos pelos próprios trabalhadores cativos, e a maior importação de bens básicos para a manutenção dos novos trabalhadores livres europeus. Esses pontos foram acentuados pela expansão monetária que - na visão dele ajudou a organizar o sistema de preços incentivando a produção de cafés mesmo quando internacionalmente estes preços estavam caindo (DELFIM NETTO, [1959] 2009, p.32)

Por outro lado, o câmbio no final da década de 1880, ao se elevar mais rapidamente do que o aumento dos preços do café (apesar de não haver encilhamento naquele período) contribuiu para conter os estímulos de novas plantações. Mantendo-se o preço interno menos elevado do que o externo:

No momento, a elevação dos preços do café compensava as pequenas colheitas e a receita de divisas, recebida pela venda do produto, cresceu de maneira considerável. Graças a isso e a operações financeiras levadas a efeito pelo governo imperial, o câmbio começou a melhorar a partir de 1887 para atingir, no ano da proclamação da república, uma média que não se registrava desde 1873: $26 \frac{7}{16}$ dinheiros por mil réis. Esse mecanismo corrigia, em parte, os estímulos para novas plantações e provenientes das elevações dos preços internacionais (...) (DELFIM NETTO, [1959] 2009, p.30)

Destaca-se desta última passagem que o incentivo em moeda nacional havia sido forte o suficiente para mitigar o aumento das plantações mesmo em período de preços internacionais florescentes, algo que não é destacado por Bacha. Este prefere apenas afirmar que as plantações cresceram devido ao aumento do preço externo, sem maiores preocupações. 
Bacha continua sobre o que ele considera a interpretação clássica daquele período pelos historiadores brasileiros:

(...) a conclusão que se segue é a de que a desvalorização do começo da década de 1890 não se refletiu imediatamente sobre os custos salariais, aumentando assim a rentabilidade da produção (de café, como de outras atividades voltadas para o comércio exterior), e tendendo a provocar uma expansão da capacidade produtiva (BACHA, 1992, p.26)

Ou seja: para Bacha, Delfim e outros entendem que a compressão dos salários unicamente permitiu o aumento das plantações. Com forma de ir contra a esse ponto, Bacha se utiliza de Ocampo (1984), o qual diz que as razões para o aumento da produção de café em fins de 1880 e início de 1890 foram:

Primeiro, o comportamento dos preços em dólares reais do café em Nova Iorque; segundo, o fato de que os preços do café no interior da Colômbia nesse período aumentaram ainda mais do que os preços do café posto em Nova Iorque, devido a reduções substanciais nos fretes marítimos e melhorias significativas no sistema de transporte doméstico, as quais muito reduziram a diferença entre os preços ao produtor e ao consumidor. O mesmo raciocínio aplica-se obviamente a São Paulo, onde a construção de ferrovias reduziu substancialmente os custos de transporte a partir da década de 1870 (Bacha, 1992, p.26)

Certamente Delfim não ignora nenhum desses pontos. Nem que houve aumento do café em Nova York, nem que as melhorias do transporte não tenham reduzido custo;

Vimos que a resposta da oferta aos estímulos dos preços foi enorme na década anterior. No começo do século ela foi ainda maior. A construção das estradas de ferro Paulista, Sorocabana, Ituana, Mogiana e Rio Clarense havia transformado em recursos efetivamente utilizáveis uma quantidade enorme de terras férteis, apropriadas para a plantação do cafeeiro, e a corrente imigratória havia se acentuado enormemente, melhorando as disponibilidades de mão de obra (DELFIM NETTO, [1959] 2009, p.35)

Bacha ainda contesta:

(...) uma avaliação detalhada dessa controvérsia para o caso do Brasil teria que ser objeto de um estudo especial, mas, mesmo aceitando a evidência sobre o comportamento dos salários nominais, em princípio é difícil explica-la meramente por rigidez salariais derivadas do sistema de colonato, conforme sustenta Delfim Netto, porque os trabalhadores eram, em sua maioria, imigrantes e as importações representavam uma parcela importante de sua cesta de consumo

Este ponto não parece abarcar o argumento de Delfim:

Inicialmente os custos de produção do café, não cresceram na mesma proporção que a desvalorização cambial; por sua vez, o rendimento residual, que é o lucro, expandiu-se. À medida, entretanto, que a situação se ajustava e dada a importância maior do comércio exterior 
no custo da vida naquele tempo (em que se importavam quase todos os gêneros de consumo), também os salários tendiam a crescer, crescimento esse que era pressionado ainda pela falta de mão de obra, escassa diante das possibilidades de expansão da lavoura cafeeira. É importante notar-se que essa escassez persistiria mesmo depois que os preços do produto tivessem caído, pois as novas áreas plantadas exigiam um volume proporcionalmente maior de braços e a taxa de entrada de imigrantes havia diminuído (DELFIM NETTO, [1959] 2009, p.49, grifos meu)

Assim, não vemos como Delfim poderia se enquadrar no que Bacha descreve como tradição de explicar o aumento da expansão da cultura cafeeira pela rigidez do salário. Aparentemente, para Delfim, à medida que se criavam os incentivos para se aumentar a cultura cafeeira, eram acompanhados quase pari passu pelos aumentos de salários dados a escassez destes. Nem ignora, como Bacha dá a entender, o fato de os imigrantes terem parte de sua cesta de consumo formada por produtos importados.

Bacha conclui:

Se isto é correto, fatores reais (ie, o aumento nos preços reais internacionais do café causados pela expansão da demanda mundial, e a redução nos salários reais causada pela expansão da imigração europeia) foram a fonte do aumento da lucratividade na produção cafeeira no início da década de 1890 (BACHA, 1992, p.27)

A conclusão de Bacha é bastante diversa da de Delfim. Em primeiro lugar, aquele autor parece não aceitar que a expansão monetária pudesse afetar o direcionamento da produção brasileira, mas quer enfatizar que fatores reais são a razão do aumento da produção ${ }^{203}$. Em segundo lugar, é Bacha que afirma que houve redução dos salários reais, e não Delfim. Como vimos, para Delfim, os salários reais não diminuíram com a imigração. Pois se tinha uma "escassez" de mão de obra para as culturas cafeeiras.

Há, também, a interpretação de Furtado que dialoga com esta aqui exposta. Em seu livro Formação Econômica do Brasil (lançado no mesmo ano que o livro do Delfim em questão) apresenta uma explicação diversa da de Delfim. Para Furtado, dois mecanismos funcionavam de maneira fundamental: em primeiro lugar, a taxa de câmbio corrigia as diminuições de entrada de divisas em períodos de recessões no preço do café, mantendo assim o lucro do cafeicultor ${ }^{204}$. Neste ponto, parece estar em harmonia com Delfim: o

\footnotetext{
203 Talvez essa insistência em fatores reais seja uma influência da "Crítica de Lucas", na qual talvez não aceitasse que a inflação tendo causas puramente monetárias pudessem afetar a produção no país.

204 “O processo de correção do desequilíbrio externo significava, em última instância, uma transferência de renda daqueles que pagavam as importações para aqueles que vendiam as exportações. Como as importações eram pagas pela coletividade em seu conjunto, os empresários exportadores estavam na realidade logrando socializar as perdas que os mecanismos econômicos tendiam a concentrar em seus
} 
cambio atuava de maneira a realocar os incentivos dos produtores brasileiros por meio de mudanças nas relações dos preços. Contudo, o segundo ponto é que o lucro mantinha-se, pois havia uma abundância muito grande de mão-de-obra a qual residia no setor de subsistência, e, portanto, os salários não se transformavam em custos para o produtor, pois a mão de obra nunca escasseava a este ponto. Aumentando-a, ainda mais, com o maciço ingresso de migrantes europeus. ${ }^{205}$ Levando, assim, a um incentivo para se aumentar a produção sem que houvesse pressão para elevação de salários. Nesse sentido, parece estar de acordo com Bacha, no qual afirma que houve "redução dos salários reais" nesse período como incentivo ao aumento da produção cafeeira. Contudo, é exatamente o oposto a isso que Delfim afirma: para este autor, como citado na passagem acima, houve tendência a aumento nos salários, pois a mão-de-obra era não só escassa, como cara. Garantindo um equilíbrio entre lucro e salário.

Quanto à questão sobre a desvalorização cambial de inícios da década de 1890, é interessante trazer o trabalho de Gustavo Franco, de 1983, que dá uma interpretação de “choques adversos” para a desvalorização daquele período ${ }^{206}$. Franco se concentra na

lucros." Furtado, [1959] 2007, pp.237-238. E, ainda: "Por outro lado, a cobertura dos déficits com emissões de papel-moeda criava uma pressão inflacionária cujos efeitos imediatos se sentiam mais fortemente nas zonas urbanas. Dessa forma, a depressão externa (redução dos preços das exportações) transformava-se internamente em um processo inflacionário. No último decênio do século, desequilíbrios internos desse tipo foram agravados pela política monetária que seguiu o governo provisório instalado após a proclamação do regime republicano." Furtado, [1959] 2007, p.245.

${ }^{205}$ Furtado parece se basear no modelo de Lewis sobre dois setores. O setor de subsistência fornecia mão de obra ao setor mais desenvolvido. Algo que parece ter sido motivo de discussão a cerca deste modelo é o fato de que uma das premissas era que a produtividade do setor de subsistência não aumentava. O que suscitou alguns questionamentos, pois, com o êxodo de mão de obra do setor produtor de alimentos para o setor produtor de outros bens, o setor de alimentos precisaria com menos mao de obra, alimentar mais pessoas; em outras palavras, precisar-se-ia aumentar a produtividade daquele setor. Para uma tentativa de repsosta a esse problema, temos que: "Outro ponto importante de ser levantado diz respeito a um mal entendido comum em muitas análises do modelo Lewis; este é a crença de que o setor não-capitalista seria equivalente ao setor rural ou ao setor não industrial12. Este mal entendido é conseqüência da popularidade de algumas re-leituras do modelo original que usavam o arcabouço dual para explicar fenômenos relacionados a estes dois tipos de divisão, como os modelos propostos em Ranis e Fei (1961(31)), Todaro (1969(32)) e Harris e Todado (1970(33)). No entanto, é importante notar que Lewis enfatiza que o excesso de mão-de-obra poderia ser encontrado também nas cidades na forma de sub-emprego urbano13 e me parece plausível pensar que este poderia estar presente também no setor industrial. INUI, Luis Roberto. Considerações evolucionárias em um modelo de desenvolvimento com oferta ilimitada de mão-de-obra. Dissertação, Faculdade de Economia Adminsitração e Contabilidade (FEA) da Universidade de São Paulo, São Paulo, 2006.

206 “Todas essas circunstâncias parecem indicar que o brusco retraimento dos movimentos de capital em 1891 se deveu ao colapso do mercado de capitais londrino, determinado pela liquidação da Casa Baring, que impediu quaisquer novos lançamentos de títulos sul-americanos em Londres, fossem relativos a Bonds de empréstimos ou ações de novas companhias, e também a desaprovação da City - para a qual o crescimento das emissões certamente contribuiu - aos rumos pouco ortodoxos da política monetária da nova república. De resto, a influência das novas emissões de 1891 sobre a desvalorização cambial parece ter sido marginal, sendo que parece mais razoável admitir que a desvalorização, pelos seus efeitos sobre o custo de vida e sobre o défice orçamentário, teria, em alguma medida, determinado o crescimento 
evasão de capitais - especialmente londrinos - do Brasil para explicar a desvalorização daquele período. Em síntese, enquanto Franco, parece se concentrar na conta capital para explicar a desvalorização naquele período, a análise de Delfim concentra-se mais nas transações correntes (como será visto a frente, na exposição do capítulo 2 d'O Problema do Café no Brasil, Delfim não ignora o poder que os grandes bancos tinham sobre a economia brasileira, nem a capacidade de especulação deles e nem o quanto suas expectativas poderiam afetar a economia). Para Gustavo Franco, então, a política de expansão monetária naquele período não teria efeito real sobre a economia, a não ser, o de ter afastado capitais britânicos do Brasil, acelerando o processo de desvalorização. Já para Delfim, a política de expansão monetária teria afetado as exportações e importações, piorando ainda mais a balança comercial. Coincidentemente ou não, essas diferentes interpretações podem ser refletidas no período em que estes autores estiveram no governo: o plano real, que tentou atrair o máximo de capital para manter o câmbio, e Delfim, que se esforçou o máximo para aumentar e diversificar as exportações brasileiras.

\section{Capítulo 2: o mercado cafeeiro com a intervenção estatal. Defesa episódica}

Neste capítulo, é apresentada as três operações de valorização do café. Nesta ordem: 1906-18; 1917-20; 1921-24. O convênio de Taubaté (primeira valorização) - diz-nos, Delfim - baseou-se em três pontos fundamentais: a não emissão para o financiamento da compra; a Caixa de conversão para manter-se o câmbio fixo; e o compromisso dos Estados signatários (RJ, SP e MG) de dificultar a expansão da área cultivada. Tendo em vista a hesitação da união em entrar no plano, São Paulo o liderou, conseguindo um empréstimo com o Banco Alemão no Brasil um milhão de libras; depois, um grupo de comerciantes de Nova Iorque juntou-se àqueles na valorização. Às vistas de uma maior safra do que a esperada, obteve-se mais um empréstimo de dois milhões junto ao J.H. Schroeder \& Co., de Londres (banco que também deu outro empréstimo para cobrir o empréstimo inicial do Banco Alemão) e mais um milhão de libras esterlinas com o National City Bank ${ }^{207}$. Em janeiro de 1907, a casa Theodor Wille \& Cia iniciou a compra de café tipo 7.

das emissões. (...)fica, de qualquer modo, estabelecido que o principal determinante da desvalorização cambial foi a sucessão de grandes déficits no balanço de pagamentos, verificada a partir de 1890, cuja origem remonta, principalmente, ao retraimento dos movimentos de capital para o Brasil" Franco, 1983, pp.141-142.

${ }^{207}$ Atual Citibank. 
Em junho de 1907, suspenderam-se as compras de café e o preço caiu atingindo 6 cents por libra em novembro. Para se continuar a operação, o estado de São Paulo, concedeu a um grupo franco-norte-americano a Sorocabana Railway Co. Ltd. E, oferecendo-lhes, como garantia, o produto da operação, conseguiu mais 2 milhões de libras esterlinas. Concomitantemente, o governo federal foi o fiduciário junto aos Rothschild e conseguiu obter mais 3 milhões de libras esterlinas. Em 1908, o governo federal, junto a um grupo de banqueiros coordenados pela Casa L. H. Schroeder\&Co. e pela Société Générale de Paris, conseguiu um empréstimo de 15 milhões de libras esterlinas para ajudar São Paulo a pagar as despesas de armazenagem e outros custos da operação até serem conseguidas vender com lucros as sacas armazenadas. Este último empréstimo possibilitou que as expectativas invertessem, ao se perceber que São Paulo poderia manter as sacas por bastante tempo fora do mercado, levando a uma melhora dos preços, o que possibilitou que o empréstimo todo fosse pago em 1914 (4 anos antes do vencimento). Ao fato de que todas essas casas internacionais do próprio setor cafeeiro terem fornecido os recursos é de suma importância para Delfim, pois os riscos da operação passaram a ser, em certa medida, riscos deles. ${ }^{208} \mathrm{Um}$ dos componentes mais importantes, para o autor, do sucesso da operação foi a inversão de expectativas. Antes do empréstimo de 1908, a expectativa era que São Paulo não conseguiria manter os preços, quando se percebeu que os preços poderiam ser mantidos, todo o mercado passou a ser comprador, esperando a alta.

Quando, entretanto, Sielcken e o Estado de São Paulo (amparado na garantia da União) puderam convencer um grupo de banqueiros a respeito da viabilidade de completar a operação com bom êxito e foi possível consolidar toda a dívida a curto prazo que havia sido contraída, os empresários compreenderam que o esquema não terminaria violentamente, como esperavam, e que, em virtude das pequenas safras em perspectiva, os preços do café iriam mesmo se elevar. Essa inversão da expectativa levou os empresários a procuraram fazer estoques, o que pressionou os preços (DELFIM NETTO, [1959] 2009, p.78, grifos meus'.

Evidencia-se o quanto, nesta perspectiva, o próprio poder de atuação do Brasil era pequeno frente aos grandes bancos. Em destaque, os internacionais. Para o autor, o grande mérito da defesa foi o momento certo no qual ela atuou. Momento no qual, como a partir de 1902 as novas plantações de café tinham sido proibidas, e após, a grande safra de 190607, seguir-se-ia, sucessivas safras pequenas, o lucro da especulação foi praticamente repassado aos Bancos, e aos estímulos que se deu ao aumento da concorrência

${ }^{208}$ Delfim Netto, [1959] 2009, p.69 
internacional. Caso a operação não funcionasse, as dívidas ficariam com São Paulo, pondo em risco a própria economia brasileira.

Delfim é crítico a esta intervenção, pois acredita que ela foi feita "para atender aos interesses de uma classe que sofria os azares da atividade empresária" (DELFIM NETTO, [1959] 2009, p.64), ao invés de solucionar "um problema de mercado". E se confundiu o problema de uma parcela da população que eram os produtores de café, com o próprio problema do Brasil. E, essa defesa levou a um aumento abrupto dos preços (quando da inversão das expectativas) criando condições extremamente favoráveis para a concorrência. Esta defesa, contudo, contou com um ponto fundamental que outras não contariam: a produção de café brasileiro era, ainda, em menor quantidade do que o consumo havia podido absorver aos preços vigentes.

A segunda operação valorizadora, entre 1917 e 1920, aconteceu antes de todos os estoques da anterior terem sido liquidados. Deve-se ter em mente de que o Brasil passava, por conta das emissões da caixa de conversão (até 1914), por uma ascendente inflacionária, mas que por conta da entrada de capitais, a taxa de cambio manteve-se estável até 1913, quando das perspectivas de guerra, a pressão das importações forçou a baixa da taxa cambial. Somado aos défices governamentais sustentados pela emissão (a partir de 1914), a inflação não deu trégua. Em 1917, os estoques no porto de Santos eram de 6 milhões de sacas, quantia assustadora aos padrões da época. O consumo se retraiu muito devido a guerra, mas a produção não, o que levou o estado de São Paulo a realizar compras em 1917. Todavia, Delfim não crê que foram estas que aumentaram o preço, mas sim a geada e o fim da guerra em 1918, levando a um aumento da procura por parte dos especuladores, que esperavam pelo menos dois anos de safra pequena por razão do acidente no Brasil. Ao final de 1918, São Paulo vendeu seus estoques obtendo grande lucro, dividindo-o com a União. Sendo as compras financiadas por emissão de papelmoeda, isso representou um imposto (sob forma de inflação) sobre toda a coletividade. Delfim lamenta que o lucro não tenha sido usado para resgatar as emissões. Logrou-se, pois, devido a guerra, os índices de preços aumentaram mais no exterior do que no interior, contribuindo para a estabilidade cambial. Infelizmente, comenta o autor, que com os louros atribuídos à operação, abandonou-se às restrições de crescimento da oferta.

A terceira operação valorizadora, de 1921 até 1924, é na qual é consagrada a tese, de acordo com Delfim, de que o problema do café era um problema nacional. Assim, somado ao fato de que as outras valorizações tiveram bons resultados, sob direção do Conde 
Siciliano, "nomeou-se uma comissão de banqueiros (Rothschild, Schroeder e um representante da Brazilian Warrant Co.) e um elemento escolhido pelo governo brasileiro para tratar da liquidação paulatina dos estoques" (DELFIM NETTO, [1959] 2009, p.97).

Delfim elenca duas principais razões para essa operação ter sido bem sucedida: o aumento vertiginoso do consumo de café nos EUA (devido a proibição do consumo de álcool por lá) e, as safras pequenas que sucederam em 1921 e 1922. Contudo, ao se entrar em 1923, e a safra era esperada muito grande, o governo prontamente interviu, colocando em armazéns reguladores no interior do país, já, assim, começando a por em prática um plano de defesa permanente.

Essa indicação de defesa permanente foi ruim, pois:

mostrava aos importadores [de café] que eles não passariam mais ao controle do mercado e que por muito tempo poderíamos impor nossos preços. A única saída para tal situação seria o estímulo da produção de outros países. Sabe-se, aliás, que muitos investimentos americanos foram realizados na Colômbia nessa época (DELFIM NETTO, [1959] 2009, p.100)

Ou seja, se, nas outras defesas - principalmente na primeira - a operação fora bem sucedida, pois era coadunada com bancos financeiros internacionais dos principais países, esta, ao bater de frente com os interesses dos importador-especuladores teria levado-os a procurar alternativas ao monopólio brasileiro ${ }^{209}$.

Capítulo 3: o mercado cafeeiro com a intervenção estatal. A defesa permanente.

"A defesa permanente se realizou ao mesmo tempo que a terceira operação valorizadora e foi parte integrante dela" (DELFIM NETTO, [1959] 2009, p. 107). Em 1924, o governo federal conseguiu vender seus estoques e pagar o empréstimo de 9 milhões de libras, passando ao estado de São Paulo os encargos da defesa. Dezembro do mesmo ano criase, na cidade homônima, o Instituto de Defesa Permanente do Café. Para o autor, a defesa permanente tirava os poucos méritos que houve com as anteriores. Estas foram sempre bem sucedidas, pois o mercado - após uma alta de preços - esperava sempre uma ou duas colheitas menores; o excesso não era tão grande, sendo cabível sua retirada do mercado;

\footnotetext{
209 Afirma, no capítulo seguinte: “durante a campanha Hoover, em 1925, tornou-se um lugar-comum afirmar-se que os Estados Unidos deveriam interessar outros países na produção do café e que deveriam encorajá-los, adquirindo os seus produtos." Delfim Netto, [1959] 2009, p.109. Também, "O mecanismo utilizados para a defesa, precisamente por sua eficiência, gerou grande irritação nos importadores, que compreenderam que agora lhes seria impossível (...)reconstituir os seus estoques e passar novamente ao comando do mercado.” Delfim Netto, [1959] 2009, p.99; e ainda: “A única saída [para os importadores] para tal situação seria o etímulo da produção de outros países. Sabe-se, aliás, que muitos investimentos americanos foram realizados na Colômbia nessa época.” Delfim Netto, [1959] 2009, p.100
} 
era sempre coadunada com a ação de grandes importadores e de grandes bancos. Depois de o governo brasileiro ter começado a controlar o café em armazéns no interior, impediuse, assim, a ação dos especuladores (esta que fora o principal fator do desfecho favorável das outras intervenções) que já não mais pesava favoravelmente à defesa; como impossibilitou os produtores nacionais e internacionais a se aperceberem do descompasso entre oferta e procura, havendo-se criado um incentivo desmedido ao aumento da oferta. O qual antes era menor.

Então, com a defesa permanente, em 1929, em compasso com a quebra da bolsa de Nova Iorque, o preço do café despencou. O instituto não conseguia arcar com o ônus, e, junto a um grupo de banqueiros liderados por J. H. Schroeder \& Co. Ltd., obteve um financiamento de 2 milhões de libras naquele ano, e mais um empréstimo de 20 milhões de libras esterlinas "integralizado por um conjunto de banqueiros americanos e europeus" (DELFIM NETTO, [1959] 2009, p. 121) em 1930210.

"Em outubro de 1930, um governo de força assumiu a direção do país" (DELFIM NETTO, [1959] 2009, p. 122). Com essa curta declaração, Delfim descreve a Revolução de 1930. Alguns elogios àquele governo são feitos, contudo discretamente. Para o autor, em face da grande crise que se encontrava o mundo, não era possível deixar o sistema de preços funcionar livremente, pois - sendo os excedentes mais do que duas vezes o consumo mundial - não haveria diminuição no preço que fizesse os operadores entrarem comprando os excedentes $^{211}$. Em face disso, defende a atuação do governo à época:

A operação de queima foi muito criticada, mas é preciso considerar-se que até hoje não se conseguiu imaginar uma política que a substituísse com probabilidades de bom êxito. De fato, a queima do café significava, em parte, a forma pela qual o desperdício generalizado de fatores, produzido pela crise mundial em todos os países, se apresentava no Brasil. À alternativa mais imediata para a queima do produto era o

\footnotetext{
${ }^{210}$ Para Delfim, os empréstimos puderam ocorrer de maneira veloz, pois: "em primeiro lugar, quase da metade do novo empréstimo se destinava a consolidar dívidas de curto prazo com os próprios banqueiros ingleses; em segundo lugar, a forma de organização do empréstimo garantia sua liquidação em dez anos e o pagamento dos juros; em terceiro lugar, o empréstimo auxiliaria a resolver o grave problema econômico nacional, e, indiretamente, contribuiria para a segurança dos grandes investimentos ingleses no país. Na realidade, o empréstimo tirava das mãos do instituto a defesa dos preços do café e, à parte das possíveis manipulações da estimação das colheitas com um ano de antecedência, a influência do instituto entrava rapidamente em decadência." Delfim Netto, [1959] 2009,p.122

${ }^{211}$ Nas palavras de Furtado no Formação Econômica: "Era perfeitamente óbvio que os estoques que se estavam acumulando não tinham nenhuma possibilidade de ser utilizados economicamente num futuro previsível. Mesmo que a economia mundial lograsse evitar nova depressão, após a grande expansão dos anos vinte, não havia nenhuma porta pela qual se pudesse antever a saída daqueles estoques, pois a capacidade produtiva continuava a aumentar. A situação que se criara era, destarte, absolutamente insustentável"
} 
desemprego e a desorganização social. (...) Produzir café para queimálo é de fato absurdo; mas não há duvida de que queimar uma saca de café é, do ponto de vista social, menos importante do que despedir um chefe de família e força-lo a roubar ou a prostituir sua esposa para alimentar seus filhos (DELFIM NETTO, [1959] 2009, pp.126-127) (12. $^{212}$

Um dos pontos em polêmica sobre esse período é se se conseguiu aumentar parte da exportação de café (obter-se um aumento de market share), ao se baixarem os preços, entre 1930-38, (apesar do retrocesso no ano seguinte, devido ao início da Guerra). Para Delfim, o aumento da exportação de café neste período deu-se por dois motivos principais: "Uma parte desse aumento se destinava à formação de estoques por parte dos operadores do mercado, que procuraram realizar suas compras diante da ameaça permanente de volta do Brasil à antiga política" (Delfim Netto, [1959] 2009, p.128). E outra parte, explicada ao se ter roubado mercado dos concorrentes: "Os preços no disponível, em Nova Iorque, caíram, de 11 cents/libra-peso, para o Santos 4, em 1937, para 7,7 em 1938. O aumento do diferencial entre os preços do Brasil e dos concorrentes ampliou as exportações" (Delfim Netto, [1959] 2009, p.128). Esta é uma evidência importante ao argumento geral de Delfim, de que o Brasil conseguiria ter forçado o mercado com preços mais baixos, evidenciando que a elasticidade do café existia, i.e., o mercado era responsivo a uma baixa de preços ao se diminuir a participação dos concorrentes.

Esta explicação parece estar em sintonia com aquela observada por Furtado, ao afirmar que: “(...)deixada de lado a preocupação de defender os preços, abria-se a possibilidade de forçar o mercado. E assim se fez, logrando um aumento do volume físico exportado, entre 1929 e 1937, de 25 por cento" (FURTADO, [1959] 2007, p.265)

Ainda com Furtado, o qual afirma que o consumo per capita não aumentou:

Em 1933 esse consumo era exatamente igual ao de 1929. (...) no período seguinte, de elevação de renda (1934-37), os preços pagos pelo consumidor continuaram a baixar, tendo sido de 25,5 centavos por libra em 1937, contra 26,4 em 1933. Houve assim dois efeitos positivos no sentido do aumento do consumo: elevação da renda real per capita e baixa de preço. Contudo, o consumo se manteve praticamente inalterado, tendo sido de 13,1 libras per capita em 1937, contra 13,9 em 1931 e 12,5 em 1933 (FURTADO, [1959] 2007, p.268)

Assim, nos parece que a explicação mais provável para se ter concomitantemente um aumento das exportações brasileiras de café mantendo-se o consumo estanque (e a renda

\footnotetext{
${ }^{212}$ Bacha se refere a essa passagem como “jóia do Keynesianismo Fabiano” (BACHA, 1992, 62).
} 
per capita crescente) é a de que o Brasil roubou mercado de outros fornecedores, ou que houve um aumento do estoque por parte dos importadores, ambos argumentos salientados por Delfim. Além disso, a Colômbia em 1937 entrou com um programa de defesa de seu café, fazendo o preço de seu produto aumentar.

Bacha levanta um ponto interessante: “(...) também se necessita de pesquisas mais detalhadas sobre a política de comercialização do café na década de 1930, que possam esclarecer por que as autoridades brasileiras esperaram até 1937 para declarar uma <<guerra de preços>>” (BACHA, 1992, p.61).

Delfim, aqui também, possui uma contribuição neste sentido. Diz o autor que a razão para se declarar essa guerra de preços fora política, antes de econômica: "Em novembro de 1937, pouco antes do golpe de Estado e provavelmente com o objetivo de obter a simpatia da cafeicultura (...)” (DELFIM NETTO, [1959] 2009, p.128). Assim, um dos objetivos da "guerra de preços" foi uma tentativa de o governo obter as simpatias dos cafeicultores.

De qualquer forma, esse "governo de força" continuou com o programa de compra de café, e, com o medo da safra volumosa de 1931-32, o governo federal resolver interferir e começaram-se a designar os estoques destinados às "cotas sacrifício"213. Essas compras de estoque foram financiadas por meio de expansão monetária, empréstimos externos, e impostos $^{214}$. Em 1933, já se havia queimado 26 milhões de sacas, sobrando, ainda, 27 milhões em estoque. "Compreende-se por que era, de fato, impossível deixar-se o sistema de preços funcionar livremente" (DELFIM NETTO, [1959] 2009, p. 126).

Delfim vê com bons olhos este período (até 1949), pois se conseguiu estabelecer a produção de café em conformes com a demanda, ao elevar-se o custo médio da produção com as quotas de sacrifício ${ }^{215}$ e, pegou-se uma fatia do mercado colombiano, ao se forçar o preço. Além disso, com a destruição dos estoques, na década de 1940 observou-se uma

\footnotetext{
${ }^{213}$ Sobre os auxílios ao cafeicultor: "A proteção do governo ao setor cafeeiro também incluiu medidas para ajudar os endividados produtores rurais, especialmente no estão de São Paulo, através de seu pagamento criando, assim, moeda nova e permitindo ao devedor postergar seus pagamentos. Esse programa, conhecido como "reajustamento econômico", reduziu as d'vidas dos fazendeiros em 50\%"Baer, 1995, p.51.

${ }^{214}$ Sobre esse período de compras de café: “(...) Em particular, quanto ao café, sugere-se que os gastos com a compra de produção excedente foram financiados por taxação das exportações do produto" (ABREU, 1990, 79).

215 "Provavelmente, entretanto, a razão mais importante dessa elevação residia na instituição do sistema de "quotas de sacrifício", que elevava o custo médio da produção comercializável" (DELFIM NETTO, [1959] 2009, p.127).
} 
recuperação do preço, levando a uma irritação por parte dos EUA, incentivando-se os importadores a buscarem se estabelecer em "outras fontes" 216.

Em 1951, Brasil retoma o sistema de defesa. O preço em ascensão neste período incentiva o aumento das plantações, e, principalmente, o preço em cruzeiros subinte. $\mathrm{O}$ maior problema deste novo tipo de defesa, para Delfim, é que não se tentava estabilizar o câmbio (como fizera-se das outras vezes com o instituo da Caixa de Conversão ou da Caixa de Estabilização), e, quando a inflação fazia os custos da produção aumentarem, desvalorizava-se o "dólar-café" (essencialmente, o cambio de exportação do café), permitindo assim que o lucro dos produtores mantivessem-se em valores elevados (DELFIM NETTO, [1959] 2009, p. 137). Esta diferença, da política econômica para o café até 1945, e depois, - principalmente após 1955 - para Delfim é fundamental. Se se lembrar dos primeiro capítulo dessa dissertação, depois de 1950, é que se parece então, que o governo começa com a política de se tentar agradar a todos.

\section{Capítulo 4: o crescimento da concorrência}

Delfim descreve como o Brasil, no final do século XIX, concorria no papel minoritário com a Ásia. Depois, suplantando-a, passará a mostrar como a concorrência colombiana pela primeira vez emergiu, já em início do século XX, mas com mais força a partir de 1920, e, depois da segunda guerra mundial, como a produção africana começou a tomar corpo, tornando-se uma ameaça já em 1950.

Em meados para o final do século XIX, o domínio da produção cafeeira era dividida com a Ásia, sendo que cabia a cada um dos países fornecer a metade de uma demanda de 5 milhões de sacas.

entre 1865 e 1885, o consumo mundial passou de mais ou menos 5 milhões de sacas por ano para cerca de 10 milhões, enquanto a exportação asiática se manteve praticamente constante e a brasileira cresceu de pouco mais de 3 milhões para cerca de 6 milhões. Apesar da melhor qualidade, os fornecimentos asiáticos perdiam terreno devido ao grande diferencial de preço existente entre eles e os cafés brasileiros (DELFIM NETTO, [1959] 2009, p. 137)

\footnotetext{
${ }^{216}$ Delfim não comenta, mas parece que um ponto importante neste período de guerras para se manter os preços do café baixos, foram as pressões dos EUA ao impedir que o Brasil reajustasse o preço do café. "As pressões brasileiras para reajustar os preços de café levando em conta a explosão dos custos de produção foram em vão, as autoridades norte-americanas argumentando que um aumento nos preços contrariaria a política de controle de preços nos Estados Unidos, perturbaria "o funcionamento ordeiro do mercado" (...)" (ABREU, 1990, p.96).
} 
Ademais, completa o autor, o café javanês tinha seus preços regulados mensalmente pela rede de comércio holandesa, acrescentado ao fato de ser controlado de maneira estatal, resultava em um ajuste de preços mais moroso do que o brasileiro, o qual conseguia se ajustar inteiramente, favorecendo o ganho de mercado.

Quanto à produção colombiana, esta não foi muito favorecida pelo convênio de Taubaté (apesar de ter influenciado um pouco), mas foi somente durante a Primeira Guerra Mundial que a eliminação de boa parte dos riscos da atividade cafeicultura por parte da operação de defesa brasileira, que permitiu que a produção crescesse com voracidade na Colômbia. O ponto fundamental de o porquê o convênio de Taubaté não influenciou em muito no aumento da concorrência, foi que:

(...) a operação contou com uma colaboração muito estreita dos próprios comerciantes, comandados por Sielcken, os quais, tendo o controle em suas mãos, não tinham qualquer necessidade de desviar a sua procura para os café de outras procedências (DELFIM NETTO, [1959] 2009, p. 139)

Já, para o aumento da concorrência colombiana, não pesou menos o interesse dos operadores (e especuladores) do café dos Estados Unidos:

Provavelmente, foi menos o preço do café (que, a não ser nos últimos anos da defesa, era muito diferente do que se poderia esperar que fosse sem ela) do que o sentimento de frustração que levou os importadores a procurar quantidades crescentes de cafés colombianos. (...) como dissemos no capítulo anterior deste trabalho, os operadores norteamericanos tinham toda uma organização instalada no Brasil e o custo da transferência para a Colômbia não deveria ser pequeno (DELFIM NETTO, [1959] 2009,p.144)

Alguns anos depois, a própria Colômbia criaria a Federación Nacional de Cafeteros de Colômbia, a qual atuou como uma espécie de órgão defensor dos preços na Colômbia também, permitindo, assim, com o aumento de preços do seu produto, uma elevação da participação do café brasileiro de 52\% em 1937, para 60\% em 1938. Mas a Federación já não tinha muito mais recursos para continuar e o resultado provável é que teria que enveredar para a inflação para continuar a comprar as sacas. Nesse sentido, Delfim acredita que o pacto de cotas que o Brasil fez com a Colômbia serviu mais para salvá-la do que para ajudar o Brasil, tendo em vista que o Santos 4 estava conseguindo ganhar muito mercado.

Por outro lado, a concorrência Africana, para o autor, não se desenvolveu pelos movimentos dos preços, mas sim, pelas dificuldades de pagamentos internacionais que 
os países europeus se encontravam na crise de 1929. Assim, puderam incentivar as suas colônias a produzirem um produto que seria por eles importado, podendo manter suas próprias moedas nas transações, estreitando as relações comerciais. Mesmo assim, o Brasil teve um papel importante neste desenvolvimento:

(...)não pode haver dúvida, no caso do café, que estímulos importantes para a sua expansão derivavam também da política de preços imposta pelo Brasil. Aliás, os dois fatores[dificuldade de pagamentos e preço] se interacionam. Quando os preços são elevados, aumenta o interesse da metrópole de restringir as suas importações das áreas não coloniais. Por outro lado, os empresários particulares têm um maior interesse na cultura. Essa coincidência de interesses tende a gerar grandes ampliações da produção (DELFIM NETTO, [1959] 2009,p.150).

Ao aumento da concorrência que se faz presente no período que Delfim escreve, se deve às grandes majorações de preço defendidas pelo Brasil na década de 1940-50. Por outro lado, o autor passa a explorar o maior problema da concorrência africana no período, que seria a do café solúvel. Para se tentar convencer sobre a resolução de que os africanos não conseguiriam competir com preços baixos, Delfim estima quais seriam os custos do café solúvel. Usando-se o relatório da Federal Trade Commission ${ }^{217}$, ele estipula as curvas de custo dos torradores de café, afirmando que existem grandes ganhos de escala nesse sentido.

Descreve os três estágios que em geral o café passa a partir do importador, até o preço no varejo. Primeiro o importador o compra por $p_{i}$, repassando-o ao torrador com uma margem de $5 \%$; o torrador, portanto, recebe seu café por $p_{i}{ }^{*}(1,05)$. Ademais, no processo de torração, o café perderia peso, sendo necessário 1,17 libra-peso de café verde para produzir uma libra de café torrado. Pelo relatório da Federal Trade Commission, Delfim estipula que o custo por libra de café produzido dos torradores deve ser o suficiente para manter as casas menores de torração produzindo. A curva de custo deles seria, então: $c_{r}$ $=1,17 *(1,05) p_{i}+12$ (ou, $c_{r}=1,23 p_{i}+12$ ) Sendo que 12 são os custos em cents somados, calculados pelo relatório por libra de café, das maiores casas de torração.

Das menores casas de torração, o custo seria de 19 (aproximadamente). Assim, pode concluir que a curva de venda dos torradores seria: $1,17 *(1,05) p_{i}+19$ (ou, 1,23 $\left.p_{i}+19\right)$. Por útlimo, os varejistas acrescentam uma porcentagem fixa de $10 \%$, resultando em $1,1 * 1,17 *(1,05) p_{i}+21$ (ou seja: $\left.1,35 p_{i}+21\right)$.

\footnotetext{
${ }^{217}$ Federal Trade Commission. Report of the investigation of coffee prices. Washington, 1954.
} 
Feito esse raciocínio, Delfim tenta confrontá-lo com os dados que obtém da realidade entre os anos de 1947 e 1956. Fazendo uma regressão entre os dados do preço de importação desses $\operatorname{anos}\left(p_{i}\right)$ e o preço de varejo $(p)$, obtém a seguinte equação: $p=1,493 p_{i}$ $+13,25$; utilizando-se da distribuição $\mathrm{F}$, constrói m intervalo de confiança de $99 \%$ e não rejeita a hipótese nula de que $\beta=1,35$. Contudo, para se calcular os custos de produção do café solúvel, Delfim apenas utiliza-se dos dados de custo fornecido no relatório mencionado.

Comparando a curva de custo do café solúvel com a outra curva de custos do café regular $\left(c_{r}=1,23 p_{i}+12\right)$, conclui que abaixo do preço de importação de 55 cents, seria mais barato o café regular, corroborando a tese de que beneficiaria ao Brasil abaixar o preço do café. Pois, os "robustos", fornecidos majoritariamente pela África, eram os tipos mais usados para o fabrico do café solúvel ${ }^{218}$.

O interessante é notar o processo pelo qual Delfim chega à função que relaciona preço de importação e preço de varejo: a primeira, utilizando-se de um raciocínio dedutivo, e depois, calcula uma regressão entre os preços observados para confirmar se poderia aceitar seu raciocínio. Sua conclusão é a de que a inclinação que ele havia obtido pelos dados empíricos não se pode rejeitar (ou "falsear") pela realidade.

Por outro lado, o aumento da concorrência por outros países, deu-se, pela política de aumento de preços brasileira. Mas há um ponto fundamental que percorre todos estes quatro primeiros capítulos: o poder dos especuladores, bancos e casa de importação, especialmente norte-americanas, é mais importante do que o puro aumento do preço em si. A concorrência só se instaura, realmente, a partir do momento que o Brasil age e dá um "golpe final" na possibilidade de especulação por parte deles. Ao momento em que este país tenta tomar para si o monopólio dos ganhos financeiros com o café, é o momento em que ele mais incorre em problemas. São inimigos fortes demais para o Brasil confrontar-se de frente, e acaba sendo punido por isso.

\footnotetext{
${ }^{218}$ Explicação de como Delfim faz para se poder comparar as duas curvas: como o produtor de café solúvel compra-o verde do importador, enfrentaria o mesmo preço de $(1,05) p_{i}$, contudo, afirma que se era necessário 3,65 libras-peso de café verde para se produzir uma libra peso de café solúvel; resultando em: $3,65^{*}(1,05) p_{i}$. Dado que se é calculado um custo de 107,6 cents por libra-peso de café solúvel, a equação final obtida por Delfim é: $c_{S}=3,65 *(1,05) p_{i}+108$. ( $c_{S}$ é a curva de custo do café solúvel). Por outro lado, ele afirma que a relação entre o rendimento de uma libra-peso de café regular e de café solúvel é de 1:4, portanto deve-se dividir $c_{S}$ por quatro, para se poder comparar as duas curvas de custo, obtendo: $c_{S}=0,96 p_{i}$ $+27$
} 


\section{Capítulo 5: um modelo do mercado cafeeiro}

Apesar de todo o livro tratar, obviamente, sobre o café e seus desdobramentos, este capítulo é o que mais vem a tratar de primeira parte do título: "O Problema do Café(...)". Delfim constrói um modelo para tentar compreender o funcionamento do mercado desta rubiácea, e assim, concluir que há, inerentemente a este mercado, um problema no qual o livre-funcionamento do mercado não o resolveria.

Dessas observações, conclui-se, portanto, que o mercado cafeeiro é inerentemente instável e que o livre funcionamento dos mecanismos de mercado deverá apresentar um preço que flutua amplamente (DELFIM NETTO, [1959] 2009, p.183.Grifos no original).

$\mathrm{Na}$ introdução do primeiro capítulo do livro, Delfim constrói um modelo mais simples do mercado cafeeiro, se apoiando no modelo da "Teia de Aranha" (cobweb). Neste capítulo, vem a construir um modelo mais aprofundado, e conclui que aquele modelo, famoso à época para lidar com questões do mercado agrícola, não serve para a análise do café:

no mercado cafeeiro, as condições de estabilidade são muito mais complicadas do que nos modelos comuns de cobweb e, mesmo no caso em que a inclinação da curva de procura (b) for maior do que a inclinação da curva de oferta (g), não está garantido que o sistema converge para um preço de equilíbrio (DELFIM NETTO, [1959] 2009, p.182).

A formalização do modelo é dada passo a passo. Primeiro para a curva de oferta, e depois, para a curva de demanda. Delfim elenca algumas premissas, explica-as em linguagem escrita, para depois escrevê-la em linguagem matemática. Assim:

\section{A curva de oferta:}

$1^{\circ} \mathrm{O}$ café só passa a ser produtivo a partir de 4 anos

Em t, somente os cafés plantados em, no máximo, $t$-4 produzirão.

$2^{\circ}$ Os cafés tem diferentes produtividades conforme o passar do tempo

$f_{1}(t)$ é a porcentagem de cafeeiros plantados no início do ano 0 (zero) vivos; $f_{1}(t)$ é aproximada pela fórmula $f_{1}(t)=1-0,025$; dando um máximo de 40 anos para o cafezal.

Assim, a quantidade de café no ano $t$ é dada pela fórmula:

$$
\mathrm{C}(t)=\sum_{4}^{w} C_{\mathrm{t}-i} f_{1}(i) \text {, w sendo a idade máxima do cafeeiro. }
$$

$f_{2}(t)$ função que retorna a produção de café por pé de café com $t$ anos. 
Assim, a produção desses cafeeiros no ano $t$ é:

$$
\mathrm{C}(t)=\sum_{4}^{w} C_{\mathrm{t}-i} f_{1}(i) f_{2}(t)
$$

$3^{\circ}$ Simplifica $f_{1}(i) f_{2}(t)$ chamando a função só de $f(\mathrm{t})$

Assim, Delfim pôs em linguagem matemática simples pontos: o café tem maturação em 4 anos; o cafeeiro tem uma idade limite; e, cada ano de plantação dos cafeeiros, estes terão uma produtividade que varia e é diferente de ano para ano.

Depois, expande um pouco mais a curva de oferta, “aqui também nos auxiliará a análise histórica que realizamos", ( ou seja, os capítulos iniciais) "Verificamos que geralmente, quando os preços subiam dentro de quatro ou cinco anos, a oferta tendia a se elevar, o que mostra que $c_{t}$ responde a $p_{t}$. (DELFIM NETTO, [1959] 2009, p.171). E, continua:

Por outro lado, vimos que a oferta tendia a se avolumar à medida que
persistia a alta de preços ou que ela se acentuava. (...) Quando os preços
estão subindo, o agricultor espera que eles continuem assim ( o mesmo
acontece quando estão baixando). Dessa maneira, $c_{t}$ também responde
a $p_{t-1}$. Vimos, anteriormente, que uma das variáveis mais importantes
para explicar-se o crescimento da concorrência eram as divergências
existentes entre os preços do café e os preços de todos os outros
produtos que poderiam ser cultivados alternativamente. A variável $c_{t}$
responde, portanto, à variações de $T_{t}=p_{t} / A_{t}$, onde $A_{t}$ é uma média
dos preços dos produtos alternativos (DELFIM NETTO, [1959] 2009,
pp.171-172). Aqui se exemplifica o processo no qual a partir de simples constatações apriorísticas (mesmo que no arcabouço da descrição histórica) vai-se construindo um modelo a partir de um processo de condensação da linguagem e transformação dela em símbolos matemáticos que permitam expressar apenas aquilo considerado relevante, neste caso, que a oferta de café reage a variações nos preços dos produtos que poderiam ser cultivados alternativamente à rubiácea.

Assim, é concluído que se pode aproximar $c_{t}=n+g p_{t}+h p_{t-1}+m T_{t}$. Nessa função estão contidas as informações acima descritas (quais sejam: a plantação de café varia com o preço atual, com o preço do momento anterior e com a variação do preço de outros produtos que poderiam ser plantados em lugar do café, o chamado custo de oportunidade do café.)

Então, a curva de oferta do café resultaria em: $S_{t}(t)=\sum_{4}^{w}\left(n+g p_{t-i}+h p_{t-i-1}+\right.$ $\left.m T_{t-i}\right) f_{i}$ 


\section{A curva de demanda:}

$1^{\circ}$ Procura no ano $t$ depende do preço no ano $t$ e pelo nível do rendimento ${ }^{219}$ :

$$
D_{t}=a+b p_{t}+c R_{t} \text { (onde, } D_{t} \text { é a quantidade consumida } p_{t} \text { é o preço no ano }
$$

t. $e, R_{t}$ é a renda no ano $t$.)

$1.1^{\circ}$ Tem-se que levar a variação populacional ao longo do tempo

$$
D_{t}=a+b p_{t}+c R_{t}+d N_{t}
$$

$2^{\circ}$ "Nos capítulos anteriores, mostramos que existe clara evidência de que os operadores do mercado funcionam como uma espécie de buffer-stock, procurando aumentar as suas compras quando as perspectivas eram de alta e reduzindo-as quando as perspectivas eram de baixa. Existe, portanto, além da curva dos consumidores, uma procura de especulação, ${ }^{220}$ Essa procura de especulação converte-se em:

$$
e\left(\hat{p}_{t+1}^{\prime}-p_{t}^{\prime}\right) \text {, onde, e é um parâmetro positivo, } \widehat{\square}_{\square+1}^{\prime} \text {, é o preço }
$$

estimado e $\square_{\square}^{\prime}$ é o preço do café verde.

$2.1^{\circ}$ Há uma relação entre o preço do café verde $\left[\square^{\prime}\right]$ ]e o torrado [ $\left.\square_{\square}\right]$

$$
\square_{\square}^{\prime}=f+r \square_{\square}
$$

Portanto: $\operatorname{er}\left(\widehat{\square}_{\square+1}-\square_{\square}^{\prime}\right)$

\section{A procura global de café no ano $t$ é, então:}

$$
D_{t}=a+b \square_{\square}+\square \square_{\square}+d \square_{\square}+\operatorname{er}\left({\widehat{\square_{\square+1}}}_{\square}-\square_{\square}^{\prime}\right) \text {, aproxima } \widehat{\square}_{\square+1}
$$

por $\square_{\square}+k\left(\square_{\square}-\square_{\square+1}\right)$. Uma maneira de aproximar as expectativas dos operadores, a qual Delfim considera um tanto inercial. Rearranjando os termos chega em: $D_{t}=a$ $+(b+\square \square \square) \square_{\square}+\square \square \square \widehat{\square}_{\square+1}+\square \square_{\square}+d \square_{\square}$.

\section{Igualando Oferta e Demanda:}

\footnotetext{
${ }^{219}$ Ao afirmar que a procura do café depende do nível de rendimento, Delfim cita o próprio artigo, de 1955, “A curva de procura do café no mercado norte-americano no período 1925-1952.", escrito para a revista dos mercados.

${ }^{220}$ Delfim Netto, pp.169-170 “A buffer stock scheme (commonly implemented as intervention storage, the "ever-normal granary") is an attempt to use commodity storage for the purposes of stabilising prices in an entire economy or, more commonly, an individual (commodity) market.[1] Specifically, commodities are bought when there is a surplus in the economy, stored, and are then sold from these stores when there are economic shortages in the economy.'[1]
} 


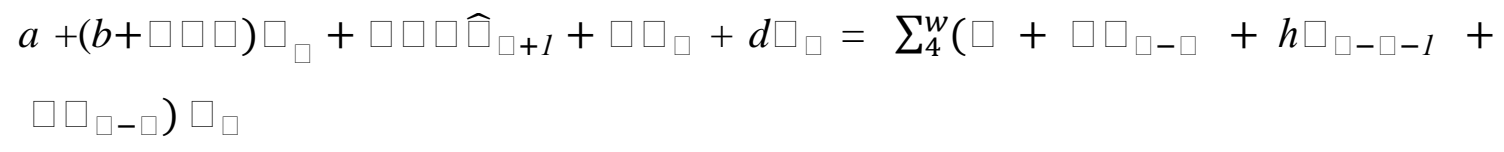

Esta é uma:

equação a diferença linear, não homogênea, de ordem $(w+1)$. Essa equação mostra que, de fato, o preço do café no ano $t$ depende, não somente da posição das variáveis exógenas em $t-R_{t}, N_{t}$ e $T_{t}$, mas de todos os preços, de $P_{t-1}$ até $P_{-}(t-(w+1))$, onde $w$ é a idade máxima do cafeeiro. Estamos portanto, em presença de um sistema largamente hereditário, em que o passado determina o presente e, no qual, as variáveis exógenas representam o papel de impulsos novos sobre a história. Não é possível discutir-se as condições de estabilidade da equação, principalmente porque se desconhece a magnitude dos parâmetros (DELFIM NETTO, 2009, p.172)

Cabe aqui, uma pausa na argumentação de Delfim para que algo seja evidenciado: até esta parte do capítulo, a matemática foi usada como parte de um processo de simplificação da linguagem escrita. Transformaram-se algumas hipóteses muito simples em símbolos, das quais todas foram elucidadas e explicadas previamente, para chegar a sua conclusão transcrita na passagem justa anterior. Ele primeiro afirma que oferta depende de preços dos períodos anteriores, para, posteriormente, concluir, que realmente, a oferta depende de preços do período anterior. Isso evidencia que um dos exercícios que Delfim gostaria de suplantar era mais do que utilizar a matemática como ferramenta para a solução de algum problema; aqui e muitas vezes, a matemática tem final em si mesma, o que se pode considerar como uma tentativa de adequação à uma linguagem de um tipo específico de economista. Ou que provavelmente estar-se-ia montando um modelo para que depois fosse aplicado, evidenciando o caráter maior que o livro o próprio livro em si, como instrumento a ser aplicado quando possível.

Depois de montado o problema, cabe a parte de solucioná-lo. Tenta-se chegar, a partir dessa equação, à estabilidade do equilíbrio. Utilizando-se de um trabalho de Samuelson

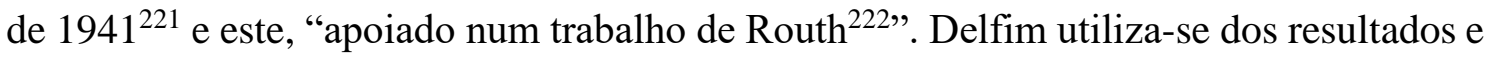
da metodologia obtida por Routh e Samuelson para tentar ver se a equação a diferenças por ele montada é estável. Primeiro, ao mostrar que com a exata equação definida por ele, a solução não é possível de se chegar. "Infelizmente, não é possível, por enquanto, aplicar-se a teoria anterior, porque não conhecemos o valor dos parâmetros da equação a

\footnotetext{
${ }^{221}$ SAMUELSON, P.A. "Conditions that the roots of a polynomial be less than unity in absolute value. Annals of Mathematical Statistics, v.12, n.3, p.360, 1941.

${ }^{222}$ ROUTH, E. J., A treatise on the stability of a given state of motion, (London, 1877)
} 
diferenças que resulta do equilíbrio do mercado."(p.175) O grande problema reside na interpretação de $\square_{\square}$, no que tange a produtividade do cafeeiro. Delfim, sem saber como essa função varia, passa a fazer algumas hipóteses sobre ela. Primeiro, tenta resolver o problema considerando-a linear. Depois, $\square_{\square}=f(i)=u m^{i}$, onde $u$ é a razão de uma progressão geométrica e menor do que 1. E, mesmo assim, "não é possível dizer-se algo a respeito do comportamento dos preços, mas os casos particulares que resolvemos mostra que se deve esperar um comportamento oscilatório bastante complicado (...)"(p.180). Delfim apenas pode afirmar que os preços oscilariam, mesmo considerando que a elasticidade da procura e da oferta, em termos absolutos, são iguais.

Delfim ataca, assim, duas frentes: a primeira, que considerava que o mercado era instável pois a curva de oferta era mais inclinada do que a curva de demanda - já que era considerado que o café tinha uma demanda bastante inelástica - dessa forma, o problema do café não estava (não, pelo menos, somente) no desenho das curvas. Ele surgia da própria complexidade de seu produto. Era inerente ao mercado de café a instabilidade, com ou sem intervenção estatal. E, não se podia confiar que o modelo cobweb era suficiente para a análise desse mercado.

\section{Capítulo 6: Relação entre o mercado cafeeiro e a economia nacional}

O capítulo 6 é a explicação da segunda parte do título do livro "O Problema do Café no Brasil". Enquanto o capítulo 5 havia sido a explicação do problema do café - digamos, ubiquamente - agora, demonstra como este problema afeta a economia brasileira per se. Portanto, o problema do café, no Brasil. Se, do capítulo 5, conclui-se que o mercado cafeeiro tem um problema de instabilidade intrínseca, neste capítulo, será apresentado um modelo de como este problema sui generis se contracena e interage com a economia brasileira.

A formalização do modelo: primeiro, o preço internacional é mais formado pela oferta e procura do que em função da taxa cambial.

Em condições de livre funcionamento, tanto do mercado cafeeiro como do mercado cambial, a sua interação pode causar perturbações que aumentam a amplitude do desajustamento a ser corrigido (como ocorreu, por exemplo, durante o "encilhamento"), mas a análise histórica anterior mostrou que o preço do café se fixa principalmente em função da oferta e da procura do produto (Delfim Netto, [1959] 2009, p.185-186). 
Destaca-se um ponto, que será devidamente melhor tratado na conclusão deste capítulo; esta análise histórica é, não outra, do que a que está contida nos quatro primeiros capítulos do livro.

O modelo de Delfim, por outro lado, sobre como a economia nacional se relaciona com o mercado do café, se baseia em oito assunções, as quais são transformadas em oito fórmulas matemáticas. (Delfim faz questão de afirmar que este modelo é o "mais simples possível" e que é "uma simplificação pouco realista" (DELFIM NETTO, [1959] 2009, p.187)

(1) $s_{t}=a_{1}+b_{1} p_{t-4}$ [Oferta de Café]

(2) $d_{t}=a_{2}+b_{2} p_{t}+d_{3} \overline{\square_{\square}}$ [Demanda de café $]$

(3) $P_{t}=c_{t} p_{t}$ [Preço Interno do Café]

(4) $S_{t}=a_{3}+b_{1} p_{t}+d_{3} c_{t}$ [Oferta de divisas]

(5) $D_{t}=a_{4}+b_{4} Y_{t-1}+d_{4} c_{t}$ [Demanda por divisas]

(6) $Y_{t}=a_{5}+b_{5}(r-1)+d_{5} N_{t}$ [Renda]

(7) $N_{t}=a_{6}+b_{6} p_{t}$ [Atividade do País]

(8) $r_{t}=a_{7}+b_{7} p_{t}$ [relação de troca com país]

De (1), que a oferta de café reage ao preço internacional de 4 períodos anteriores. De (2), que a demanda do café depende do preço internacional do café do período atual e da renda total externa da coletividade $\left(\overline{\square_{\square}}\right)$. De (3), que o preço interno do café varia linearmente com o preço internacional do café; de (4), que a oferta de divisas depende do preço internacional do café e do nível da taxa cambial de equilíbrio. De (5), que a demanda por divisas varia juntamente com a renda brasileira do período anterior e da taxa de câmbio de equilíbrio. De (6) que a renda da coletividade depende do nível de relações de troca do Brasil com o exterior e do nível de atividade do país. Por seu lado, as equações (7) e (8) explicam que o nível de atividade do país depende do preço interno do café e que, o nível das relações de troca dependem do preço externo do café.

Junta as equações, chegando em:

(9) $n_{1}+n_{2} p_{t-4} C_{t-4}+n_{3} p_{t}$ 
(10) $m_{1} p_{1}+m_{2} p_{t-1}+m_{3} p_{t-1} c_{t-1}+m_{4} c_{t}+m_{5} n$ e $m$ são combinações lineares entre os parâmetros. Mas, baseando-se em um trabalho do Haavelmo de $1940^{223}$, afirma que a solução desta equação pode levar a "conclusões completamente sem sentido" (DELFIM NETTO, [1959] 2009, p.188). Apesar dessa afirmação, passa a admitir a hipótese de que é possível analisar o comportamento dos preços "à luz dos fatos que apontamos nos capítulos anteriores”. E que, a relação mais importante do sistema é a que existe entre o preço internacional do café $\left(p_{t}\right)$ e a taxa de câmbio de equilíbrio $\left(c_{t}\right)$ (ou seja, "café é câmbio"). Deixando de lado o modelo de equações construído, Delfim começa a descrever o modelo que ele entende que pode explicar o café no Brasil;

Supondo a procura do café inelástica, Delfim diz que um aumento da safra em determinado ano, diminuirá o preço externo $\left(p_{t}\right)$ e a oferta de divisas $\left(S_{t}\right)$. Como o efeito do nível de relações de troca $\left(r_{t}\right)$ sobre o nível de atividade interna $\left(Y_{t}\right)$ é pequeno (pois Delfim considera o mercado interno tem um nível considerável), a taxa de câmbio de equilíbrio se depreciará $\left(c_{t}\right)$. Esse é o ponto crítico, afirma Delfim. Pois, se a taxa de câmbio desvalorizar menos do que os preços em moeda estrangeira, não haverá incentivo para um aumento da oferta, contudo, caso o preço em divisas estrangeiras se desvalorize menos do que a queda na taxa de cambio (em outras palavras: caso a queda na taxa de cambio seja mais acentuada do que a desvalorização do cruzeiro) o preço do café em moeda nacional levará a um incentivo a aumentar a oferta da rubiácea por parte dos produtores brasileiros, dificultando que o equilíbrio seja atingido neste sistema ${ }^{224}$. Agora, se o sistema estiver sob um intenso processo inflacionário, é possível que o preço do café esteja sempre aumentando, e levando a um aumento da oferta, independentemente da queda do café em preços internacionais ser maior do que a depreciação do cambio que ocorre em decorrência daquela. Nesse sentido Delfim critica o financiamento da compra do café por meios inflacionários.

A longo prazo, entretanto, a taxa cambial recebe pressões mais fortes do lado da procura, principalmente da ampliação do rendimento monetário devido à inflação permanente a que esteve sujeito o país durante o último século (cujo combate se tornou efetivo nos governos de Campos Salles e Rodrigo Alves). É por esse motivo que, apesar dos preços oscilarem (sem tendência secular) e a receita de divisas crescer

\footnotetext{
${ }^{223}$ Para Haavelmo, utilizar-se do método de mínimos quadrados para se estimar um conjunto de equações exatas levaria a um erro, pois a componente aleatória que é o resíduo do MQO não é computada nas equações exatas, podendo levar a apenas a uma interpretação de um acumulado de erros.

HAAVELMO, T. The inadequacy of testing dynamics theory by comparing theoretical solutions and observed cycles. Econometrica, v.8, n.4, 1940.

${ }^{224} P_{t}=c_{t} p_{t}$, em outras palavras.
} 
por patamares, pela ampliação das exportações na fase de depressão de cada ciclo, assistimos a uma depreciação permanente da taxa cambial desde o início do período que analisamos (DELFIM NETTO, [1959] 2009, p.193)

Além disso, diz que as flutuações do preço do café foram maiores do que necessárias, agravadas pela "instabilidade da política monetária brasileira". Ou seja, para Delfim, queimou-se muito mais café do que o necessário, porque a instabilidade da política monetária introduz uma deflação adicional que incentiva a oferta a mais do que somente a compra. Por outro lado, Delfim afirma que a depreciação quase constante da taxa cambial não exerceu estímulos à exportação de outros produtos.

Agora, quando a situação do café estava ruim - não por um aumento de oferta, mas um diminuição do preço - em momentos de grande depreciação cambial, havia uma ampliação das exportações das demais culturas. Contudo, quando o café voltava a ser uma atividade rentável, desviavam-se fatores de produção de volta ao café, e se diminuía o lucro das atividades outras.

Esse é um dos aspectos mais graves do problema da diversificação do setor exportador, que encontra um obstáculo na influência da atividade cafeeira sobre o mercado cambial. Como o Brasil é importante na produção do café e como a receita de divisas proveniente do produto é importante para a determinação da taxa cambial, segue-se que existe um mecanismo compensador entre as variações do preço externo do produto e os movimentos da taxa cambial, o que dá uma maior vantagem relativa para aquela cultura. Quando, por efeito do aumento da oferta do produto, a receita cambial cai e a taxa cambial se deprecia, a remuneração do café em moeda nacional cai menos do que em moeda estrangeira, mas o preço dos demais produtos de exportação, em cujos mercados não somos importantes, crescem proporcionalmente à desvalorização. É provável, nessas circunstâncias, que a rentabilidade relativa ao setor cafeeiro seja prejudicada e que a permanência dessas condições leve a uma transferência de fatores para os outros produtos (DELFIM NETTO, [1959] 2009, p.194).

Assim, quando a cultura do café vai muito mal, dá fôlego a todas outras atividades.

Quando vai bem, rouba-lhes recursos e as impede de desenvolver.

Quando os preços do café estão subindo, o aumento da receita de divisas eleva a taxa cambial, mas o efeito dessas duas componentes tende a elevar também o preço do café em moeda nacional, ao passo que o preço dos demais produtos de exportação tende a reduzir. Nessas circunstâncias, é muito provável que a rentabilidade relativa da cafeicultura melhore de maneira muito substancial e a leve a absorver recursos de outras atividades. Como, por outro lado, a cafeicultura é um investimento de longa maturação e permanente, os recursos têm maios facilidade para entrar no setor do que para abandonálo (DELFIM NETTO, [1959] 2009, p.194, grifos nossos). 
A cafeicultura, por conseguir manter os seus trabalhadores no campo, mesmo que se dedicando à culturas alternativas, é muito resistente às baixas de preço. Sendo, portanto, muito difícil transferir recursos dessa atividade para outra. Ainda pior, em momentos de crise do café, no qual a economia torna-se menos monetária e mais natural, há-se uma diminuição do rendimento de toda coletividade, o que afetaria aquelas atividades que produzem para o mercado interno. Como as indústrias.

(...)uma parte importante da economia se torna mais natural e pode gerar um processo cumulativo que baixe o nível de rendimento de toda a coletividade. Uma parcela importante da produção industrial do país (principalmente da indústria de tecidos) é absorvida pelos trabalhadores agrícolas que, quando veem diminuída a parte do seu salário monetário, não tem meios de pagamentos para continuar a realizar aquelas compras, a não ser à custa da venda de sua produção suplementar. (...)Nessas circunstâncias, apesar de os empresários agrícolas terem possibilidade de enfrentar a baixa de preços por uma redução dos salários nominais, o processo não se realiza sem repercussões sobre o nível de procura dos produtos industriais, o que força a baixa dos seus preços (DELFIM NETTO, [1959] 2009, p.196, grifos nossos)

Nesse capítulo, pode-se ver claramente como o problema do café discutido no capítulo 5, não influencia diretamente o problema do café no Brasil. Se, naquele discute-se a inexorável inconstância do mercado cafeeiro, aqui, mostra-se que a própria dinâmica do café com a economia brasileira está corrompida pelo principal fato de o café ser um produto de cultura perene monopolizada pelo Brasil. Se, por um lado, o café é essencial para não por a economia brasileira em completo colapso, ele também enfraquece as alternativas. Para Delfim, o café se encontraria tal qual um parasita que enfraquece seu hospedeiro, impedindo-lhe a cura completa. Contudo, se esse parasita fosse expurgado instantaneamente, poderia matar seu já fraquejado anfitrião. O café para o Brasil seria como o álcool para um alcóolatra, que, impedido bruscamente de se o ingerir, acaba por esmorecer da abstinência.

A única solução, então, seria se conseguir industrializar o país acabando com a restrição externa ao se exportar outros produtos que não fossem o café. Pois, a dependência do café não só era deletéria a industrialização (pois lhe sugava os recursos), como não permitiria entradas de divisas crescentes (e com certeza, não em nível suficiente para financiar a industrialização).

Furtado, no Formação Econômica do Brasil, partilha de muitos pontos em comum desta conclusão de Delfim: 
A elevação dos preços no setor de exportação, particularmente uma elevação brusca como a ocorrida com o café em fins de 1949, se traduz inicialmente em maiores lucros para todos aqueles que detêm estoques do produto.(...) A elevação do preço do produto se comunica do exterior para o interior, onde o consumidor local terá igualmente que pagar mais por ele. Dessa forma, opera-se uma primeira transferência de renda real do conjunto da população consumidora para o setor exportador. Em segundo lugar, na agricultura, os preços do setor exportador tendem a influenciar o setor ligado ao mercado interno. Como os fatores de produção ligados ao setor exportador são beneficiados, forma-se um movimento no sentido da transferência de fatores para o setor onde houve alta de preços. A produção ligada ao mercado interno é assim prejudicada, o que é bem mais grave quando está crescendo a renda dos consumidores por efeito da elevação dos preços de exportação. Dessa situação, como é natural, terá que resultar um aumento dos preços dos produtos agrícolas destinados ao mercado interno. Se o setor exportador represente, como ocorre no Brasil, uma parte muito importante da agricultura, é perfeitamente natural que os fatores ligados ao mercado interno procurem nivelar suas remunerações pelo padrão estabelecido no setor de exportação, pelo menos em base regional (FURTADO [1959] 2007, p. 320-321)

Esse é um ponto de Delfim. O café roubaria recursos da economia, encarecendo a produção de outros produtos, inclusive ao transferir trabalhadores para o setor cafeeiro, encareceria o salário dos trabalhadores das indústrias. (Este último ponto não é faz parte da argumentação de Furtado, cabendo apenas a de Delfim);

A forma como a agricultura se adapta a essa economia de mercado duplo é em parte responsável pela instabilidade crônica da economia brasileira. Ao manifestar-se uma alta nos preços de exportação, os fatores tendem a desviar-se do setor interno para o externo. Assim, ao mesmo tempo que a renda dos consumidores está crescendo, a oferta de produtos agrícolas dentro do país tende a contrair-se por efeito daquele deslocamento de fatores. Como as inversões ligadas ao setor externo exigem, no caso do café, um período de três a cinco anos para madurar, aquela transferência de fatores poderá continuar por algum tempo sem que tenha qualquer efeito sobre a oferta externa. Enquanto se mantiver elevado relativamente o nível dos preços de exportação, haverá tendência à transferência de fatores para o setor externo. Ao madurarem as inversões nesse setor, cria-se muitas vezes uma situação de superprodução. A essa altura os preços do mercado interno possivelmente já terão subido suficientemente para nivelar-se aos de exportação (FURTADO [1959] 2007, p. 320-321)

Novamente, ressalta-se como a transferência de recursos para o "setor exportador", para Furtado, diminui a oferta de "produtos agrícolas" para o mercado interno (provavelmente com fins de subsistência), encarecendo o preço dos produtos destinados ao mercado interno. O maior problema, para Delfim desse processo é que boa parte destes produtos de exportação que sugavam os recursos internos era o café, o qual já contava com superprodução há algum tempo, e, caso não fossem as políticas internas, não seria 
necessário a transferência de nenhum recurso para o setor de exportação com o aumento de preço, pois o mercado já não conseguia absorver a quantidade de café que era produzida. Este parece ser um ponto fundamental de divergência: para Delfim o café não só roubava recursos do setores voltados à produção interna, como também impedia o desenvolvimento de alternativas à exportação, que aumentariam a entrada de divisas;

Ao caírem estes, tem início um processo inverso de transferência de fatores, aumentando a produção para o mercado interno na etapa em que se comprime a renda dos consumidores. Existe, assim, no setor primário da economia brasileira um mecanismo de ampliação dos desequilíbrios provenientes do exterior. Essa observação põe mais uma vez em evidência as enormes dificuldades com que depara uma economia como a brasileira para lograr um mínimo de estabilidade no seu nível geral de preços (FURTADO [1959] 2007, p. 322).

Como visto, para Delfim, o mercado cafeeiro era realmente intrinsecamente instável, e com propensão a aumento da instabilidade como segue:

Se considerarmos o mercado até 1930 (excluído o período da I Guerra Mundial), vemos que os preços apresentam uma acentuada tendência secular e um comportamento oscilatório, que aparentemente se estava ampliando. (...) O modelo não leva em conta dois fatos importantes, que trabalham contra a estabilidade do sistema: a)a dificuldade de se obterem recursos para se realizar a operação de retenção, e b) os estímulos para a plantação no próprio país, derivados da defesa (DELFIM NETTO, [1959] 2009, p.199-200, grifos nossos).

\section{Capítulo 7: os problemas do equilíbrio do mercado cafeeiro}

O capítulo é dividido em três partes: "O equilíbrio do mercado dentro da política de valorização"; "O equilíbrio do mercado dentro da política recente"; e, por último: "O custo social da defesa". Para se começar a discutir a primeira parte, Delfim começa a formalizar suas assunções:

Demanda mundial do café:
(1) $D_{t}=a+b \square_{\square}+\square \square \square_{\square}[$ [Demanda mundial do café $]$
(2) $S_{t}=d+f \square_{\square-4}+\square \square_{\square}$ [Oferta mundial do café $]^{225}$

\footnotetext{
${ }^{225} \mathrm{fp}_{t-4}$ é o lucro que o café proporcionou. Sendo $f$ a produtividade (já descontado os custos) multiplicada pelo preço de quatro períodos anteriores. Delfim utiliza uma função que não garante nem perdas nem ganhos à escala.
} 
A política do café seguida seria da seguinte maneira, formalizada pelo autor: dada a demanda mundial do café, o Brasil excluiria a oferta dos concorrentes $\left(S_{t}\right)$ e supriria com café o restante $\left(D_{t}-S_{t}\right)$. Obtendo, assim, tal receita:

(3) $R_{t}=(a-d) \square_{\square}+(b-g) \square_{\square}^{2}+\mathrm{c} \square_{\square} \square_{\square}-f \square_{\square-4} \square_{\square}$ [Receita de divisas]

Derivando-se, igualando-se a zero e rearranjando os termos convenientemente, Delfim expõem o que seria o valor máximo da expressão:

(4) $\square_{\square}=\frac{(\square-\square) \square_{\square}+\square \square \square-4+\square \square \square}{2(\square-\square)}$ [preço do café para que obtém o máximo de receita]

(5) $\square_{\square}=(1 / 2)\left[\left(\right.\right.$ a-d)-f $\left.\square_{\square-4}+\square \square_{\square}\right]$ [quantidade exportada por ano pelo Brasil]

(6) $\square_{\square}=\frac{\left[(\square-\square)+\square \square_{\square-4}+\square \square \square\right]^{2}}{4(\square-\square)}$ [Receita cambial máxima por ano no Brasil]

Da equação (5), Delfim a utiliza para afirmar que, como $f \square_{\square-4}$ é a resposta dos concorrentes à melhoria do lucro, a quantidade exportada pelo Brasil tende a diminuir. A equação (6) torna mais claro que a receita cambial máxima de cada ano tende a diminuir com o aumento do lucro dos nossos concorrentes. Dessa forma, por mais que se maximize a receita em cada ano, ela será menor do que seria sem a defesa do ano anterior.

Agora, faz-se a tentativa de compreender como se dá o caminho de ajustamento dos preços, reajustando a equação (4) e chegando a:

(7) $(\square-\square)+2(\square-\square) \square_{\square}+\square \square_{\square-4}+\square \square_{\square}=0$

Para resolvê-la mais facilmente, assume que o rendimento cresce a uma taxa $m$ anual e constante:

(8) $2(\square-\square) \square_{\square}+\square \square \square-4=\square \square_{0}(1+m)^{\mathrm{t}}+(\square-\square)$

A equação característica de (8) é:

$\square^{\square-4}\left(\square^{4}+\frac{\square}{2(\square-\square)}\right)=0$

Conclusão do Delfim:

Como, pela natureza do problema, $b$ é negativo e $g$ e $f$ são positivos, temos quatro raízes imaginárias conjugadas duas a duas, o que dá um movimento oscilatório, cuja amplitude depende da magnitude da fração $f / 2(g-b)$. Se a fração for menor do que 1 , o movimento será amortecido; se for igual a 1, será de amplitude constante; e, se for maior do que 1, será explosivo (DELFIM NETTO, [1959] 2009, p.199). 
Da forma como Delfim desenhou o problema, chega-se a um comportamento que pode aparentar estranheza: a curva de oferta do Brasil é negativamente inclinada em relação ao preço. De $D_{t}-S_{t}$, temos que a curva de oferta do Brasil é $s_{t}=(a-d)+(b-g) \square_{\square}+\mathrm{c} \square_{\square}$ - $f \square_{\square-4}$. Pela construção do problema (como já dito), $b$ é um parâmetro negativo e $g$ e $f$ são positivos. Assim, o Brasil tem uma oferta que é estritamente complementar, significando que a cada aumento de preços do produto, os outros países aumentariam a oferta (tanto por estímulo do preço presente, como do preço de quatro períodos passados), restando ao Brasil apenas complementá-la com menos do que no período anterior. Dessa forma, o preço ascendente no período $t$, diminuiria a oferta do Brasil - pois aumenta a dos concorrentes estimuladas pelo preço em $t$ - contudo, há um "carrego" de oferta que já sofreram estímulos em $t$-4. Como o Brasil é o responsável pelo estabelecimento do preço, e sua política é a de manutenção das receitas, entra-se em um processo em espiral: quanto maior o aumento de preços, menos o Brasil exporta. Quanto menos exporta, maior precisa ser o preço para se manter o nível de receitas com divisas. Basta-se saber se essa espiral aumenta o bocal do vórtice, ou o diminui. Para que esse preço tenha comportamento explosivo - dado as hipóteses - basta que a componente que aumenta a oferta dada por quatro períodos anteriores $(f)$ seja ligeiramente maior - em valor absoluto - do que a resposta complementar ao produto no período coetâneo por parte do Brasil ( $b$ $-g$ ). Dessa forma, os resultados de que $f / 2(g-b)$ devem ser menores do que 1 para não ser explosivo já estava contido nas hipóteses ${ }^{226}$.

Como não se pôde encontrar o valor dos parâmetros para essas equações (mesmo problema exposto por Haavelmo, como explica o autor), o professor Delfim parte para a análise histórica do caminho dos preços. Ao que afirma que, como os preços não tinham uma tendência na segunda metade do século XIX, e só passam a tê-la após o convênio de Taubaté, e, desde então até 1930 há uma tendência e um comportamento oscilatório que se apresentava oscilando, "é muito possível, portanto, que a magnitude do módulo das raízes imaginárias fosse maior do que 1 ".

\footnotetext{
${ }^{226}$ Para simplificar, chamemos " $(b-g)$ " (a inclinação da curva de oferta residual brasileira em relação ao preço presente) de $k$. Assim, temos que $f / 2(g-b)$ ou $\frac{f}{-2 k}<1 ; 1 / 2 f<-k$. Como $k$ pela construção é um valor negativo, $-k$ é por suposto positivo. Assim, $|f|<2|k|$ já está contido no que se sabia que $|f|<|k|$ para não se ter uma resposta explosiva. Pois se se sabia que ' $f$ ' deveria ser menos que ' $k$ ' para não se ter uma resposta explosiva, a informação de que ' $f$ ' deve ser menor que dois ' $k$ ' para não se ter uma resposta explosiva não acrescenta em nada.
} 
O modelo já descrito, é, ainda, pormenorizado por Delfim ao comentar que aquele não contém a dificuldade em se obter recursos para se realização da operação e não leva em conta os estímulos que a defesa dá ao aumento da cultura no próprio país. Dois fatores que introduziriam ainda mais instabilidade a um mercado - como já visto - já instável.

\section{O equilíbrio do mercado dentro da política de café do período}

Há, para o autor, duas formas pelas quais o governo realizou a defesa do café. Uma na qual o governo regulava a entrada de cafés no mercado (e discutida acima). Uma outra, começada depois da II guerra mundial [chamada de agora por Delfim] no qual o governo fazia o controle definindo a taxa de câmbio (ou os preços) de exportação desse produto. A diferença dá-se, pois, na segunda forma o Brasil fixa o preço que venderá, e a procura absorve o que lhe apraz a esse preço.

Delfim se utiliza do modelos de Smithies ${ }^{227}$ para analisar o mercado com expectativas de preços dos outros produtores (África, robusta e Colômbia, milds). A hipótese é que o Brasil fixa o preço sabendo que a Colômbia fixará o preço baseado no preço em que o Brasil fixar e no preço do mild do período anterior. Formaliza esse modelo com seis equações (cada país esperando os outros dois) e tenta resolver as equações a diferenças. Mas, faltando informações, assume que:

Essas considerações nos permitem mostrar que muito provavelmente F1 deve ser negativo, pois é essa a única maneira de explicar-se o comportamento histórico que encontramos nos três primeiros itens deste trabalho. Podemos, portanto, tomar F1, G2 e H3 como sendo números negativos (DELFIM NETTO, [1959] 2009, p.208) 228

Novamente, depois de uma formalização partindo de um modelo de inferências, ao não as resolver, utiliza-se de um conhecimento empírico feito a partir de observações.

Ainda, não conseguindo chegar a alguma conclusão com a formalização matemática:

Não é possível, pelas propriedade associadas $\mathrm{K}$ e L, mostrar-se que todos os menores principais são positivos, como seria preciso para provar-se que o módulo de todas as raízes é menor do que 1, de maneira que não é possível saber-se a priori se o movimento será convergente ou divergente. A experiência histórica tem mostrado, entretanto, que quando existe a ameaça de retaliação (caso de instabilidade), o comportamento do Brasil e da Colômbia é muito cautelosos,

\footnotetext{
${ }^{227}$ SMITHIES, A. equilibrium in monopolistic competition. Quaterly journal of economics 1940 - para explicar o modelo monopolístico do Brasil em relação a receita máxima. E, ainda, SMITHIES, A. The stability of competitive equilibrium. Econometrica, v.10, n.3, 4, 1942.

${ }^{228} \mathrm{~F} 1$, G2 e H3 são, respectivamente a resposta da procura de cafés brasileiros a uma modificação dos preços do Brasil, da Colômbia e da África.
} 
procurando-se evitar sempre um política de competição, cada país aceitando uma posição intermediária para proteger-se de eventuais prejuízos decorrentes daquela política (DELFIM NETTO, [1959] 2009, pp.208-209).

Conclui que o mercado, desenhado como curvas de interações e expectativas entre os principais produtores, é inerentemente instável e que a única forma de não o ser é se houver um entendimento entre os principais produtores. Conclusão esta que será, no capítulo nove, rejeitada.

O custo social da defesa é o último tópico desse capítulo. Neste, discute-se dois assuntos em separado: "o preço mínimo de compra", e "as relações de troca". O ponto central é que tanto o preço mínimo de compra, quanto a manutenção do câmbio com a retenção de sacas leva a fatores mal alocados no Brasil que atrapalha o desenvolvimento. O problema do preço mínimo: $1^{\circ}$ não ajuda os produtores menos produtivos ${ }^{229} ; 2^{\circ}$ Os melhores se beneficiam amplamente dos altos lucros. Levando a não se haver incentivos para o aumento da produtividade.

A defesa impede que possa ser utilizada as melhores tecnologias no campo já existentes e liberar recursos para a indústria.

A chave do processo de desenvolvimento econômico reside principalmente numa melhoria da produtividade do setor agrícola, o que, a um só tempo, libera mão de obra e eleva o nível de rendimento dos que ficaram no campo. (...) Se considerarmos, finalmente, que esses excedentes são sustentados por um subsídio pago por toda a coletividades sob a forma de inflação, chegamos à conclusão paradoxal de que a sociedade paga pra não crescer! ()$^{230}$

Delfim insiste no ponto de que se é necessário aumentar a produtividade do setor agrícola (em especial do produtor de alimentos) para que seja liberada mão de obra para a outros setores:

A chave do processo de desenvolvimento econômico reside principalmente numa melhoria da produtividade do setor agrícola, o que, a um só tempo, libera mão de obra e eleva o nível de rendimento

\footnotetext{
229“'É evidente que a sustentação do nível de preços do café não melhora substancialmente a situação dos cafeicultores de baixa produtividade, por duas razões: a) o preço mínimo é, em geral, calculado com base nessas lavouras e deixa-lhes, portanto, uma pequena margem de lucro, e b) sendo produtores de baixa produtividade, eles têm pouco café para vender. Em compensação, os cafeicultores mais bem aparelhados e que gozam de alta produtividade (...)se beneficiam amplamente com o preço mínimo. Esse fato possui uma dupla implicação: a) tende a aumentar, de maneira muito significante, a permanência no mercado dos agricultores menos capazes, e b)tende a gerar um excesso de produção.

${ }^{230}$ Perto desta passagem, Delfim traz para auxiliar seu argumento, a "Lei de Engel" que afirma que a medida que a renda aumenta, a parte desta dispensada a alimentos cresce em menor proporção. Um dos corolários dessa afirmação é que à medida que a renda do Brasil crescesse, seria necessária menor produção de alimentos em proporção aos outros bens produzidos (DELFIM NETTO, [1959] 2009, pp.211-212).
} 
dos que ficaram no campo. É possível, num estágio posterior do desenvolvimento econômico, depender-se, em escala maior, da importação de produtos agrícolas, mas pensamos que é praticamente impossível, num país como o nosso, a geração daquele processo não se apoiar nos ganhos de produtividade da agricultura, pois, por maior que fosse a produtividade do setor industrial, ele não poderá contar com a mão de obra necessária, se essa mão de obra não for liberada das atividades primárias. (...) É, portanto, da própria essência do desenvolvimento, que ele se realize à custa de uma transferência da mão de obra da agricultura para as outras atividades, possibilitada pelos ganhos de produtividade no setor agrícola. O caminho pelo qual se realiza essa transfrência é precisamente a baixa do rendimento monetário dos produtos agrícolas. A agricultura, mais do que um negócio, é um meio de vida e é preciso, às vezes, esperar uma geração para que a transferência se efetive. (....) Chegamos à conclusão de que o próprio processo de desenvolvimento econômico se apoia em dois pontos: a) m aumento da produtividade agrícola, e b) uma transferência da mão de obra da agricultura para os demais setores da economia (DELFIM NETTO, [1959] 2009, pp. 210-211).

É importante notar que a indústrias brasileira, nessa perspectiva, poderia ser muito produtiva, e mesmo assim sofreria com problemas de custos de mão de obra que não a permitiriam competir. E, o maior desses custos, nessa passagem, é a mão de obra que resiste no campo. A compra de café é deletéria pois impede o incentivo ao aumento de produtividade, demandando mais mão de obra. Impede a transferência de recursos para outras atividades (como subsistência) encarecendo a mão de obra. Impede o aumento de receitas, pois no longo prazo entram menos do que se teria entrado em caso contrário. Impede o desenvolvimento de alternativas de exportação. Em suma, a compra de café encarece a indústria pelo custo do trabalho e pelo custo de importação, ao encarecer a compra de insumos (o que também encarece a mão de obra) necessário a industria (equipamentos, combustíveis, máquinas etc).

Além do custo da defesa onerar o uso de fatores internamente, Delfim passa a mostrar que nem sempre a proteção é algo ruim. Citando dois artigos de Samuelson para demonstrar que o livre cambismo não é a melhor política sempre, recusa que isso advogaria em favor da defesa ${ }^{231}$. Passa a formalizar um modelo simples, para demonstrar que existe um caso no qual o incentivo à exportação, por meio do câmbio mais valorizado para a importação, nem sempre produz o melhor nível de renda para a coletividade.

\footnotetext{
${ }^{231}$ SAMUELSON, P. A. Welfare economics and international trade. The American Economic Review, v.28, n.2, p.261, june 1938, e, SAMUELSON, P. A. The gains from international trade. Canadian Journal of Economics and Political Science, v. 5, p.195, may 1938
} 
Maximiza uma curva de indiferenças de utilidade, $U=U\left(\square_{\square}, \square_{\square}\right)$, sendo $\square_{\square}$ a quantidade de bens agrícolas, e $\square_{\square}$, os bens industriais. Dessa forma, se se considerar que a economia só tem estes dois bens, então $U$ é uma medida do nível de rendimento nacional. Faz um função de produção: $F(A, I)=m$, onde $A$ é a quantidade possível de produção dos bens agrícolas e $I$ a quantidade possível de produção de bens industriais, quando todos os recursos da coletividade estão empregados. Já a relação de preços é dada por $a=\frac{\square}{\square}$, a relação de preços interna e $b=\frac{\square \square}{\square}$, a relação de preços externa. O problema passa a ser, então, maximizar a função de indiferenças sujeita a função de produção, considerando-se que $\square_{\square}=A(a)-D(b)$ e $\square_{\square}=I(a)+b D(b)$, ou seja, da produção e exportação dos produtos agrícolas e da produção e importação dos produtos industriais ${ }^{232}$. Imagina uma fronteira de possibilidade de produção dada por

$4 A^{2}+25 I^{2}=1.000 .000$.

Do modelo construído por Delfim, como a produtividade da indústria é muito menor do que do campo, conclui-se que manter um câmbio artificialmente desvalorizado não ajudaria o rendimento nacional. Contudo, a maximização de $U$ retorna os parâmetros $b=2,50$ e $a=2,39$, resultado este diferente do livre-cambismo $a=b$. O problema da defesa pela manutenção do câmbio é a mudança dos preços internos, estes incentivariam a atividade industrial, que por ser menos produtiva, diminuiria a produção total, gerando um ótimo pior.

Feito este modelo, exemplificador de que nem sempre o livre mercado atinge o melhor ótimo, volta a insistir em caminho oposto: de que a defesa no Brasil, por manter os preços do café internamente, não permitiu o deslocamento de fatores da produção cafeeira para a produção industrial. Assim, seria errôneo afirmar que a indústria foi favorecida pela defesa.

Essas observações mostram que é completamente errônea a afirmação frequentemente repetida de que foi a defesa dos preços do café que facilitou o desenvolvimento industrial. A indústria somente começou a se desenvolver internamente quando a deterioração da taxa cambial levantou uma barreira suficientemente grande para garantir-lhe uma parcela do mercado interno e somente se beneficiou da defesa muito posteriormente, quando foi possível estabelecer-se um grande diferencial entre as taxas cambiais de exportação e de importação, o que ocorreu recentemente (DELFIM NETTO, [1959] 2009, p.218).

\footnotetext{
${ }^{232} \mathrm{Se} D(b)$ for a quantidade exportada aos preços $b$, então a nossa possibilidade de importação será $b D(b)$.
} 
O mais interessante é observar que as conclusões do Delfim, nesse caso, pouco tem a ver com o modelo que ele produz antes de voltar ao argumento anterior da não melhor alocação dos fatores internamente. $\mathrm{O}$ modelo serve para dialogar com os artigos de Samuelson, mas não atua em nenhuma causa para as conclusões de Delfim. O artigo do Samuelson mostra que a opção livre-cambismo não é a melhor sempre, mas nesse caso, Delfim advoga o fim da proteção ao café.

\section{Capítulo 8: o problema da elasticidade do café}

Este é o capítulo que mais se discute métodos estatísticos e se faz uma análise crítica da literatura estatística à época. O ponto do Delfim é mostrar que - assim como tentou fazer para a receita proveniente do café - a elasticidade da procura do café calculada não revela todo o processo dinâmico envolvido, e, sim, somente permite uma visão fotográfica da situação ${ }^{233}$.

Para Delfim, do ponto de vista estatístico, as elasticidades da demanda que já haviam sido estimadas poderiam ser criticadas em três frontes principais:

1. Existência de erros em todas as variáveis

2. Existência de relações simultâneas

3. Existência de autocorrelação nos erros

Delfim passa então, a se utilizar de bastantes trabalhos na área de estatística para tentar suplantar esses $\operatorname{erros}^{234}$.

De Koopmans (1937), tenta resolver o problema de erro nas variáveis. De Tintner (1952), o método para resolver a equação de Koopmans. Com Ferrar (1941), para dizer que as raízes da equação característica são reais. Hsu (1941), a distribuição das raízes segundo $\chi^{2}$, caso se conheça as variâncias dos erros. Contudo,

Na construção do teste, são essenciais as hipóteses de que os resíduos não são autocorrelacionados e que se distribuem normalmente, hipóteses que dificilmente se verificarão em problemas econômicos, de maneira que não se pode utilizar o critério Hsu-Tintner ( que foi o primeiro a utilizá-lo) senão como uma aproximação muito grosseira (DELFIM NETTO, [1959] 2009, p.222).

Tintner (1940) para se estimar as variâncias dos erros. Como, no caso do café, Delfim diz que o caminho do equilíbrio das variáveis não pode ser reduzidos a um polinômio, então,

\footnotetext{
233 Os trabalhos que Delfim cita que já haviam estimado a curva de demanda e, concluído que ela era inelástica: Gilboy, 1934; Kingston, 1939; Schlittler Silva, 1949; Stone, 1954; Fox, 1954; Szarf e Pignalosa, 1954; Klein, 1955; Delfim Netto, 1955.

${ }^{234}$ Koopmans (1937), Tintner (1952), Ferrar (1941), Hsu (1941), Tintner (1950), Klein (1953), Barlett (1949). Hald (1940), Bartlett (1949), Gibson e Jowett (1957), Klein (1950), Cochrane e Orcutt (1949), Girshick (1942), Horner (1952), Harberger (1957)
} 
apresenta Klein (1953) como alternativa para o cálculo das variáveis. Entretanto, todas essas ressalvas levam a: “(...) que todas essas estimativas não estimam o coeficiente de elasticidades, mas sim um número menor do que ele.” (DELFIM NETTO, [1959] 2009, p.223).

Wald (1940) e Barlett (1949) para se tentar determinar uma regressão entre duas variáveis sujeitas a erros. Gibson e Jowett (1957) seria um refinamento do método anterior aplicado no caso de regressão múltipla. Mesmo assim, não parecem resolver o problema das relações simultâneas e da existência de autocorrelação nos resíduos. Klein(1950), para mostrar que os coeficientes estimados da equação isolada em relação a todo o sistema, mostra que não são tão diferentes. Cochrane e Orcutt (1949) mostraram que não se poderia melhorar a qualidade das estimativas em relação à independência dos erros.

Discutido os métodos e suas limitações, Delfim passa a estimar a curva de demanda dos consumidores por café nos EUA. A primeira tentativa, de regressão múltipla usando-se $Y$ (consumo per capita), $X_{1}$ (preço real) e $X_{2}$ (rendimento real), resulta em uma solução descartada pelo autor pois o consumo de café diminuiria, de acordo com o resultado, em relação ao aumento da renda, como se se tratasse de um bem inferior. Refaz a regressão, utilizando somente a variável $X_{1}$, e, ao resultado, aplica o método de Wald-Bartlett e depois encontra o intervalo de confiança a 95\% que aprova o estimador encontrado. Conclui que é, realmente, inelástica a curva de demanda, com ressalvas: "a)trata-se da procura dos consumidores; b) refere-se ao mercado norte-americano; c)refere-se a níveis de preço não muito discrepantes dos atuais; d)é válida a curto prazo"

O próximo ponto é encontrar a elasticidade da procura dos cafés brasileiros, tendo em vista os cafés colombianos e africanos. Formaliza utilizando-se das curvas de reação, e arremata com a ideia de que a procura de café do Brasil depende, não somente de seu preço, mas também dos preços dos concorrentes.

Não tem, portanto, nenhum sentido falar-se de elasticidade da procura do café brasileiro, a não ser dentro das hipóteses sobre $p, p_{1}, p_{2}$. A definição clássica de elasticidade não tem sentido, porque supõe a condição ceteris paribusm que não se verifica. Vemos que a procura de café brasileiro por parte dos torradores é uma procura derivade da dos consumidores, mas o fato mais importante a notar-se é que existe uma elasticidade de substituição do café brasileiro pelos "suaves" de um lado, e pelos "robustas" de outro (Delfim Netto, 1954) ${ }^{235}$. Isso significa que, mesmo quando o consumidor não reage às modificações dos

${ }^{235}$ Artigo discutido no capítulo um do presente trabalho. 
preços, o torrador o faz, substituindo os cafés brasileiros pelos de outra procedências, sempre que isso possa trazer-lhe maiores lucros (DELFIM NETTO, [1959] 2009, p.242)

Esse argumento é fundamental para Delfim. E, o fazia já há algum tempo, como o primeiro capítulo deste presente trabalho deixa indicado. A dificuldade se encontra em formalizar este argumento, que, dentre todos os outros, é um dos mais fáceis de se entender: os compradores vão comprar o café que mais lhes favorecer os lucros, sejam eles provenientes do Brasil, da Colômbia ou da África. Mesmo assim, partindo-se de simples assunções (que o preço do café da Colombia e da África dependem do preço do café do Brasil, e que a quantidade exportada do café do Brasil depende dos preços destes outros dois países) chega-se a bastante intrincadas relações algébricas.

Mas, independentemente de todos esses cálculo e formalizações:

Este capítulo mostrou que o problema da determinação da elasticidade da procura do café brasileiro é muito mais complexo do que pode parecer à primeira vista e que a simples aplicação do método estatístico é incapaz de resolvê-los (DELFIM NETTO, [1959] 2009, p.248, grifos nossos).

Assim, a conclusão que Delfim queria chegar - a de mostrar que a elasticidade é diferente no longo e no curto prazo e de que para a política cafeeira deve ser levada em conta em ambas as situações - não a consegue por meio de todos estes métodos estatísticos, os quais são largamente considerações dedutivas formalizadas.

\section{Capítulo 9: o problema dos acordos internacionais}

O capítulo 9 consiste em discutir as tentativas de acordos internacionais por parte dos países produtores de café. A situação à época era:

Em 1957, chegou-se a um acordo parcial entre os principais produtores latino-americanos e assinou-se um documento conhecido por Convênio do México, o qual simplesmente fazia referência a quantidades a serem exportadas. Para a safra presente (1958/59) continua em vigor um acordo do mesmo gênero, pelo qual o Brasil se comprometeu a retirar do mercado cerca de $85 \%$ dos excedentes mundiais (DELFIM NETTO, [1959] 2009, p.248, grifos nossos).

Delfim retoma o ponto de que o melhor para a estabilidade do mercado de café seria um acordo internacional entre os países produtores. Contudo, isso não significa que ela seria melhor para cada país em particular, em especial para o Brasil (Delfim Netto, [1959] 2009, p.253, grifos nossos). Nenhum dos três tipos de acordo - estoques reguladores, acordo multilateral de compra e venda e acordo de quotas - interessariam ao Brasil. 
Capítulo 10: as possibilidades do Brasil dentro do mercado cafeeiro internacional

Este penúltimo capítulo serve como síntese das principais conclusões de Delfim (enquanto o $11^{\circ}$ capítulo é exatamente uma listagem de 33 pontos das conclusões do livro). Uma coisa fica ainda mais evidente: o café deve ser utilizado para alavancar o nosso desenvolvimento econômico, e não por algum outro motivo, "doesse a quem fosse". O desenvolvimento industrial aconteceu no Brasil com transferência de mão-deobra do campo para a cidade, sem uma contrapartida de melhoras na produtividade. Esta foi compensada por uma ampliação da agricultura para terras mais férteis. Mas não fora o suficiente para diminuir os custos internos, levando a tornar as outras exportações mais "gravosas". Com o café impedindo que a pauta de exportação seja mais plural, era-se cada vez mais difícil financiar o parque industrial para atendimento do mercado interno.

Somando tudo isso, a posição que o Brasil deveria tomar era a de baixar os preços, para se conseguir conquistar alguns mercados perdidos, e mercados em crescimento. Assim, por mais que a conhecida inelasticidade do café faça-se presente, isto somente é válido para o curto prazo. Na relação dinâmica, amplos períodos de preços baixo do café tendem a aumentar a taxa anual de consumo. O Brasil teria ainda mais vantagens por poder produzir a mesma quantidade de produto, utilizando-se apenas de 1/3 dos fatores utilizados na época. A defesa do café nos faz perder externamente, por darmos lugar a outros produtores, e, pior, internamente, pois não permite um reajuste da produção, diminuindo custos de outras atividades, especialmente da indústria.

Na seguinte passagem do capítulo 11 de Delfim, que trata sobre o resumo das conclusões, Delfim confirma a pior alocação interna originada pela defesa do café:

O custo social da defesa do café foi muito superior ao que geralmente se estima, pois manteve no mercado os produtores menos eficientes e gerou inicialmente condições muito desfavoráveis ao desenvolvimento industrial. Posteriormente, a disparidade criada entre as taxas cambiais de exportação e de importação impediram uma distribuição eficiente dos fatores de produção, o que tende a compensar os ganhos obtidos nas relações de troca (DELFIM NETTO, [1959] 2009, p.275). 


\section{Fonte}

\section{Artigos diversos}

DELFIM NETTO, A. "Discurso proferido à turma de formandos de 1956" in O Canguru, órgão do Centro Acadêmico "Visconde de Cairu”, FEA/USP: São Paulo, 1957.

DELFIM NETTO, A. "Para Sempre Professor: Entrevista" in Revista Agitação, $\mathrm{N}^{\circ}$ 107, Ano XVIII, Set/Out, 2012.

DELFIM NETTO, A. Alguns Problemas do Planejamento para o Desenvolvimento Econômico, Tese de concurso catedrático, São Paulo, 1962.

\section{Artigos Bolsa de Mercadorias}

DELFIM NETTO, A. "A Tendência Estacional do Preço do Algodão Paulista no Período 1940-1950". in: Revista dos Mercados. São Paulo: Bolsa de Mercadorias de São Paulo, Ano 2, Número 22, Junho, 1952a.

DELFIM NETTO, A. PÉCORA, J. F. "Rendimentos Reais dos Títulos Públicos Federais em São Paulo - 1944 a 1951 - ". in: Revista dos Mercados. São Paulo: Bolsa de Mercadorias de São Paulo, Ano 3, Número 30, Fevereiro, 1953.

DELFIM NETTO, A. "Considerações Sôbre a Depreciação Cambial". in: Revista dos Mercados. São Paulo: Bolsa de Mercadorias de São Paulo, Ano 3, Número 33, Maio, $1953 \mathrm{a}$.

DELFIM NETTO, A. "Considerações Sôbre a Depreciação Cambial, Parte II". in: Revista dos Mercados. São Paulo: Bolsa de Mercadorias de São Paulo, Ano 3, Número 34, Junho, 1953b.

DELFIM NETTO, A. "A Lei de Pareto e o Imposto de Renda em 1951 no Brasil". in: Revista dos Mercados. São Paulo: Bolsa de Mercadorias de São Paulo, Ano 3, Número 36, Agosto, 1953c.

DELFIM NETTO, A. "O Problema do Algodão". in: Revista dos Mercados. São Paulo: Bolsa de Mercadorias de São Paulo, Ano 4, Número 39, Novembro, 1953d. 
DELFIM NETTO, A. "Linhas Gerais da Determinaçção Estatística da Renda Nacional". in: Revista dos Mercados. São Paulo: Bolsa de Mercadorias de São Paulo, Ano 4, Número 41, Janeiro, 1954a.

DELFIM NETTO, A. "O Café Brasileiro no Mercado dos Estados Unidos no Período de 1922-39". in: Revista dos Mercados. São Paulo: Bolsa de Mercadorias de São Paulo, Ano 4, Número 43, Março, 1954b.

DELFIM NETTO, A. HAUSNER, J. G. STILMAN, M. "O Algodão Brasileiro na Atual Conjuntura". in: Revista dos Mercados. São Paulo: Bolsa de Mercadorias de São Paulo, Ano 4, Número 48, Agosto, 1954.

DELFIM NETTO, A. "Uma Tabela da Participação nos Lucros das Emprêsas". in: Revista dos Mercados. São Paulo: Bolsa de Mercadorias de São Paulo, Ano 5, Número 50, Outubro, 1954c.

DELFIM NETTO, A. "O Sistema de Taxa Flexível e Brasil". in: Revista dos Mercados. São Paulo: Bolsa de Mercadorias de São Paulo, Ano 5, Número 54, Fevereiro, 1955a.

DELFIM NETTO, A. "Observações sobre o conceito de Elasticidade". in: Revista dos Mercados. São Paulo: Bolsa de Mercadorias de São Paulo, Ano 5, Número 55, Março, 1955b.

DELFIM NETTO, A. "A Curva de Procura do Café no Mercado Norte-Americano no Período 1925-1952". in: Revista dos Mercados. São Paulo: Bolsa de Mercadorias de São Paulo, Ano 5, Número 57, Maio, 1955c.

\section{Artigos Digesto Econômico}

DELFIM NETTO, A. "O Preço do Café e a Expectativa dos Importadores". in: Digesto Economico. São Paulo, Ano XIII, Número 137, Set./Out., 1957a.

DELFIM NETTO, A. "Algumas das origens das atuais dificuldades do comércio". in: Digesto Economico. São Paulo, Ano XIV, Número 139, Jan/Fev., 1958a.

DELFIM NETTO, A. "Problemas do acordo internacional do café". in: Digesto Economico. São Paulo, Ano XIV, Número 140, Mar/Abr., 1958b. 
DELFIM NETTO, A. "Política Cafeeira". in: Digesto Economico. São Paulo, Ano XIV, Número 142, Jul/Ago., 1958c.

DELFIM NETTO, A. "Nota sôbre o desenvolvimento do processo inflacionário no Brasil". in: Digesto Economico. São Paulo, Ano XIV, Número 143, Set/Out., 1958d.

DELFIM NETTO, A. "O acôrdo internacional do café ". in: Digesto Economico. São Paulo, Ano XV, Número 144, Nov/Dez., 1958e.

DELFIM NETTO, A. "Enfrentemos a realidade cafeeira ". in: Digesto Economico. São Paulo, Ano XV, Número 146, Mar/Abr., 1959a.

DELFIM NETTO, A. "Nova política do café ". in: Digesto Economico. São Paulo, Ano XV, Número 148,Jul/Ago., 1959b.

DELFIM NETTO, A. "Acôrdo cafeeiro internacional ". in: Digesto Economico. São Paulo, Ano XVI, Número 150,Nov/Dez., 1959c.

\section{Artigos Ciências Econômicas}

DELFIM NETTO, A. "Nota sôbre as condições de estabilidade da taxa cambial ". in: Revista de Ciências Econômicas. Ordem dos Economistas: São Paulo, Número 74, Dez/Mar. 1955-1956.

DELFIM NETTO, A. "Apreciação preliminar de alguns aspectos da reforma tarifária ". in: Revista de Ciências Econômicas. Ordem dos Economistas: São Paulo, Número 77, Junho. 1957b.

DELFIM NETTO, A. "Sugestões para uma política cafeeira ". in: Revista de Ciências Econômicas. Ordem dos Economistas: São Paulo, Número 01, Março. 1962a.

Textos de Delfim contidos no volume "Problemas Econômicos da Agricultura Brasileira", reunidos para servir de "material de leitura" no curso de Economia Brasileira

DELFIM NETTO, Antônio. "Nota sobre alguns aspectos do problema agrário" transcrito da Revista Temas e Problemas, $\mathrm{N}^{\circ} 1$, maio de 1963 in Problemas econômicos da agricultura brasileira. Boletim $\mathrm{n}^{\circ} 40$, Cadeira XXV: Economia IV - (Análise macroeconômica I. Contabilidade nacional; teoria do desenvolvimento; programação econômica; planejamento governamental) 
DELFIM NETTO, Antônio. “As informações sobre a agricultura num programa de desenvolvimento econômico" transcrito da Revista de Ciências Econômicas, $\mathrm{N}^{\circ}$ 2, junho de 1962 in Problemas econômicos da agricultura brasileira. Boletim n ${ }^{\circ} 40$, Cadeira XXV: Economia IV - (Análise macroeconômica I. Contabilidade nacional; teoria do desenvolvimento; programação econômica; planejamento governamental). [Originalmente palestra realizada no Departamento Estadual de Estatística de São Paulo, em 30-03-1962]

DELFIM NETTO, Antônio. "Uma análise da agricultura paulista (transcrito do volume Fundo de Expansão Agro-Pecuária, da secretaria de Estado dos Negócios da Agricultura - governo Carvalho Pinto, 1962) in Problemas econômicos da agricultura brasileira. Boletim n ${ }^{40}$, Cadeira XXV: Economia IV - (Análise macroeconômica I. Contabilidade nacional; teoria do desenvolvimento; programação econômica; planejamento governamental)

DELFIM NETTO, Antônio. "Nota sobre a estrutura econômica da lavoura paulista" transcrito da Revista de Ciências Econômicas, $N^{\circ}$ 2, 1960 in Problemas econômicos da agricultura brasileira. Boletim $\mathrm{n}^{\circ} 40$, Cadeira XXV: Economia IV - (Análise macroeconômica I. Contabilidade nacional; teoria do desenvolvimento; programação econômica; planejamento governamental)

DELFIM NETTO, Antônio. "Reforma agrária: o novo diagnóstico (seminário de economia brasileira, na Faculdade de Ciências Econômicas e Administrativas, em novembro de 1963) in Problemas econômicos da agricultura brasileira. Boletim $\mathrm{n}^{\circ} 40$, Cadeira XXV: Economia IV - (Análise macroeconômica I. Contabilidade nacional; teoria do desenvolvimento; programação econômica; planejamento governamental)

DELFIM NETTO, Antônio. "A agricultura no programa de ação econômica do governo - 1964/1966 (seminário de economia brasileira, na Faculdade de Ciências Econômicas e Administrativas, em outubro de 1964) in Problemas econômicos da agricultura brasileira. Boletim n40, Cadeira XXV: Economia IV - (Análise macroeconômica I. Contabilidade nacional; teoria do desenvolvimento; programação econômica; planejamento governamental) 


\section{Bibliografia}

ABREU, Alzira Alves de et al (coords.). Dicionário Histórico-Biográfico Brasileiro Pós-1930. Rio de Janeiro: CPDOC, 2010. Disponível em: <http://cpdoc.fgv.br.>. Acesso em: 04/06/2017.

ABREU, M. de Paiva. "Inflação, Estagnação e Ruptura: 1961-1964”, in Abreu, M.P. (org.), A Ordem do Progreso: Cem Anos de Política Econômica Republicana, 1889-1989, Rio de Janeiro: Editora Campus, 1990.

ABREU, M. de Paiva. “Crise, Crescimento e Modernização Autoritária: 1930-1945” in A Ordem do Progresso: Cem Anos de Política Econômica Republicana, 1889-1989. Rio de Janeiro: Campus, 1990.

AKHAVI-POUR, H. Causes of Brazilian Postwar Inflation, 1947-1964. Tese de Mestrado, Departamento de Economia, Kansas State University: Estados Unidos, 1975.

ALBERTI, V. SARMENTO, C. A. ROCHA, D. (orgs). Mario Henrique Simonsen: Um Homem e seu Tempo. Depoimentos ao CPDOC. Rio de Janeiro: Editora FGV, 2002.

AMARAL, Ricardo. "Quem faz a cabeça de Lula" in Revista Época, sem data. Pode ser encontrado em http://revistaepoca.globo.com/Revista/Epoca/0,,EDR831986009,00.html. Último acesso em 07/04/2016.

ARANHA, F. A. Tecnocracia e Capitalismo no Brasil num Estudo de Caso: a Associação Nacional de Programação Econômica e Social (Anpes) (1964-67). Faculdade de História: Universidade de Goiás, 2016. (Dissertação de Mestrado)

BACHA, E. "Política Brasileira do Café. Uma avaliação centenária" in BACHA, E. GREENHILL, R. 150 Anos de Café. Marcellino Martins \& E. Johnston: 1992.

BACKHOUSE, Roger E. "The transformation of U.S. Economics, 1920-1960, viewed through a Survey of Journal Articles" in: MORGAN, M. RUTHERFORD, M. (Eds). From interwar pluralism to postwar neoclassicism (Annual supplement to volume 30 History of Political Economy).Duke University Press. 1998. (pp. 85-107)

BAER, W. "Observações sobre o Plano Trienal” in Revista Brasileira de Economia, v. $16, \mathrm{~N}^{\circ} 4,1962$. 
BAER, W. KERSTENETZKY, I. SIMONSEN, M. H. “Transporte e Inflação: um Estudo da Formulação Irracional de Política no Brasil” in Revista Brasileira de Economia, v. 16, $\mathrm{N}^{\circ} 4,1962$.

BAER, W. KERSTENETZKY, 1. Patterns of Brtuilian economic growth. Cornell Univenity, 1966. Estudo mimeografado, depois publicado em DAVIS, T. ed. The next ten years of Latin American Growth. Cornell University Press, 1967.

BARBOSA, M. Z. ROCHA, M. B. FREITAS, S.M. "Sazonalidade dos Preços dos Principais Óleos Vegetais no Mercado Internacional” in Informações Econômicas, v.25, n.3, 1995.

BARBOSA, N. FREITAS, F. LOPES, C.F., VERNENGO, M. "Indeterminismo e a Metodologia da Economia Positiva: uma Abordagem com Base na Indeterminação de Senior” in Revista Brasileira de Economia, 1994.

BASTIAN, E. F. “O PAEG e o Plano Trienal: uma Análise Comparativa de Suas Políticas de Estabilização de Curto Prazo" in Estudos Econômicos, São Paulo, v. 43, n.1, 2013.

BASTOS, Pedro Paulo Z. "Restrição Externa e Desenvolvimentismo no Brasil: Sobre o Segundo Governo Vargas (1951-1954)" in Texto Para Discussão. Campinas: IE/Unicamp, $\mathrm{N}^{\circ}$ 202, abr. 2012.

BAUDET, H. STUIJVENBERG, J. H. "Rostow's Theory on Growth" in Weltwirtschaftliches Archiv, v. 90, 1963.

BENEVIDES, Maria V. “União Democrática Nacional (UDN)”. In: ABREU, Alzira Alves de et al (coords.). Dicionário Histórico-Biográfico Brasileiro - Pós-1930. Rio de Janeiro: CPDOC, 2010.

BIANCHI, A. M. "Sobre a matematização da Economia" in Leituras de economia política. Campinas, n²1, dez-jul de 2013-2014.

BIELSCHOWSKY, R. [1988] Pensamento Econômico Brasileiro: o Ciclo Ideológico do Desenvolvimentismo. São Paulo: Contraponto, 2012.

BINI, P. Constantitno Bresciani Turroni: Ciclo, Moneta e Sviluppo. Civitanova Marche: Otium Edizioni, 1992. 
BLAUG, M. [1962] Teoria Económica em Retropección. México, D.F.: Fondo de Cultura Económica, 2001.

BMSP (BOLSA DE MERCADORIAS DE SÃO PAULO) Revista dos Mercados, ano 1, setembro de 1950, n.1.

BMSP (BOLSA DE MERCADORIAS DE SÃO PAULO). Bolsa de Mercadorias de São Paulo 1917-1987. São Paulo: Laserprint, 1987.

BOIANOVSKY, M. Celso Furtado and the structuralist-monetarist debate on economic stabilization in Latin America. History of Political Economy, v. 44, n. 2, p. 277-330, 2012.

BOLAND, L. A. The Foundations of Economic Method: A popperian Perspective. Nova Iorque: Taylor \& Francis e-Library, 2003

BOLAND, L. A. The Methodology of Economic Model building: methodology after Samuelson. Routledge, 2000.

BRESCIANI-TURRONI, C. "Sul Carattere Delle 'Leggi statistiche'”, in Giornale degli Economisti, marzo, 1910.

BRESCIANI-TURRONI, C. Corso di Economia Politica. Volume Secondo. Giuffré Ed, Milão, 1949-1950.

BRESSER-PEREIRA, L. C. REGO, J. M. "Um Mestre da Economia Brasileira: Ignácio Rangel” in Revista de Economia Política, v. 13, n.2, 1993.

BRESSER-PEREIRA, L. C. Desenvolvimento e Crise no Brasil Entre 1930 e 1967. Rio de Janeiro: Editora Zahar, 1968.

BUENO, L. de Freitas. MANZOLI, Flávio. DELFIM NETTO, A. "Notas de Aula de um Curso de Aperfeiçoamento em Estatística Econômica" (1952). Taquigrafia de Meyer Stillman.

CAGAN, P. "The Monetary Dynamics of Hyperinflation” in: FRIEDMAN, M., Ed., Studies in the Quantity Theory of Money, The University of Chicago Press: Chicago, 1956.

CAMPOS, F. Estratégias de desenvolvimento nacional: o papel do capital estrangeiro entre o segundo governo Vargas e o governo Castelo Branco (1951-1966). Instituto de Economia, Unicamp. Campinas: 2003. Dissertação de Mestrado. 
CAMPOS, P. H. P. “A Trajetória das Mendes Júnior: um Caso Emblemático de uma das Empreiteiras da Ditadura" in CONGRESSO BRASILEIRO DE HISTÓRIA ECONÔMICA. 13, 2017, Niterói.

CAMPOS, P. H. P. A Ditadura dos Empreiteiros: as Empresas Nacionais de Construção Pesada, suas Formas Associativas e o Estado Ditatorial Brasileiro, 1964-1985, 2012. Tese (Doutorado em História Social) - Universidade Federal Fluminenes.

CAMPOS, Roberto. "Inflação e Crescimento Equilibrado" in Revista de Ciências Econômicas, Ordem dos Economistas de São Paulo: São Paulo, N³, 1960.

CANABRAVA, A. P. "As Condições Sociais, Econômicas e Políticas da Fundação”. In: CANABRAVA, A. P. (org.) História da Faculdade de Economia e Administração da Universidade de São Paulo 1946-1981 São Paulo, FEA/USP, 1984

CAPUTO, A. C. HILDETE, P. M. “A industrialização Brasileira nos Anos 1950: Uma Análise da Instrução 113 da Sumoc” in Estudos Econômicos , v. 39, N³, 2009.

CARDOSO DE MELLO, J. M.O Capitalismo Tardio. São Paulo: Brasiliense, 1982.

CARVALHO, André Roncaglia de. The Conceptual Evolution of Inflation Inertia in Brazil. TESE (Doutorado em Economia) - Faculdade de Economia, Administração e Contabilidade, Universidade de São Paulo (FEA/USP). São Paulo, 2015.

CAVALIERI, Marco A. R. CURADO, M. R. "As influências norte-americanas de Roberto Simonsen: controle social, institucionalismo e planejamento" in Estudos Econômicos, vol. 46, n.2, 2016.

CESÁRIO, A. C. C. NOLLI, J. D. M. “A marcha da produção durante o governo JK: discurso e acontecimento" in Anais do 33 encontro do CERU, 2009.

CHIAPPIN, J. R. N. LEISTER, C. "Duhem como Precursor de Popper, Kuhn e Lakatos sobre a Metodologia da Escolha Racional de Teorias: da Dualidade à Trialidade Metodológica" in Veritas - Revista de Filosofica da PUCRS, v.60, n.2, 2015.

CHIQUITO, E. de Almeida. A Comissão Interestadual da Bacia Paraná-Uruguai: do planejamento de vale aos polos de desenvolvimento. Out/2011. Tese de Doutorado. Instituto de Arquitetura e Urbanismo da Universidade de São Paulo. São Carlos, 2011.

CHOW, G. C. "Econometrics and Economic Policy” in Statistica Sinica, v.11, n.3, 2001. 
CIPOLlARI, P. Estudos Anpes $N^{\circ}$ 2: O Papel dos Intermediários Financeiros não Bancários no Processo de Desenvolvimento Econômico. (Versão Preliminar). Anpes: São Paulo, 1965.

CIRO, B. ; COZAC, L. F. L.; REGO, J. M. Conversas com Economistas Brasileiros São Paulo: Editora 34,1996.

COELHO, F. S. “Antonio Delfim Netto: formação e influência de suas análises sobre o crescimento e o desenvolvimento econômico" in SZMRECSÁNYI, T. COELHO, F. S. (orgs). Ensaios de história do pensamento econômico no Brasil contemporâneo. São Paulo: Atlas, 2007.

COMEMORAÇÃO DOS 25 ANOS DO IPEA. Maurício Galinkin. Brasília: Instituto de Pesquisa Econômica Aplicada/Centro de Treinamento para o Desenvolvimento Econômico e Social, 1989. 30 minutos.

COSTA, M. "Política Fiscal e Plano Trienal" in Revista Brasileira de Economia, v. 16, $\mathrm{N}^{\circ} 4,1962$.

CRUZ, Valdo. FOREQUE, Flávia. "Dilma convoca elite do PIB para cobrar investimentos" in Jornal Folha de São Paulo. São Paulo, 21 de março de 2012. Pode ser encontrado em http://www1.folha.uol.com.br/fsp/poder/32496-dilma-convoca-elite-dopib-para-cobrar-investimentos.shtml. Último acesso em 07/04/2016

CURI, L. Entre a história e a economia: o pensamento econômico de Roberto Simonsen. São Paulo: FFLCH/USP, 2014. Dissertação de mestrado.

DAVIS, H. T. The Analysis of Economic Time Series. Bloomington, Indiana: The Principia Press, 1941.

DAVIS, H. T. The Theory of Econometrics. Bloomington, Indiana: Principia Press, 1941.

DEAN, W., A Industrialização de São Paulo (1880-1945). São Paulo: Difusão Européia do Livro/Editora da Universidade de São Paulo, 1971.

DELFIM NETTO, A. "Nota sobre a estimação da relação Produto/Capital com os dados da contabilidade Nacional" in Revista de Administração, FEA/USP: São Paulo, 1965(b). 
DELFIM NETTO, A. "O Curso de Ciências Econômicas" in Cadernos de Economia São Paulo: Centro Acadêmico Visconde de Cairu/FCEA-USP, Nº3 jan/abr 1964, edição especial sobre a reforma do Ensino.

DELFIM NETTO, A. Alguns Problemas do Planejamento para o Desenvolvimento Econômico, Tese Catedrática, FEA/USP: São Paulo, 1962

DELFIM NETTO, A. LEFF, Nathaniel H. "Import substitution. Foreign investment, and international disequilibrium in Brazil". in: The journal of development studies. Abingdon, Oxfordshire : Routledge, Vol. 2. 1966.

DELFIM NETTO, A. O Método na Ciência Econômica. São Paulo: FCEA/USP, 1958.

DELFIM NETTO, A [1959] O Problema do Café no Brasil. São Paulo: Editora Unesp, 2009

DELFIM NETTO, A. PASTORE, A. C. CARVAlHO, E. P. Agricultura $e$ desenvolvimento no Brasil. Estudo ANPES n. ${ }^{\circ} 5$ (versão preliminar). São Paulo: ANPES, 1966.

DELFIM NETTO, A. Planejamento para o Desenvolvimento Econômico, Livraria Editora Pioneira e Editora da Universidade de São Paulo: São Paulo, 1966

DELFIM NETTO, A. Problemas econômicos da agricultura brasileira. Boletim $\mathrm{n}^{\circ} 40$, Cadeira XXV: Economia IV - (Análise macroeconômica I. Contabilidade nacional; teoria do desenvolvimento; programação econômica; planejamento governamental), [s.d.]

DELFIM NETTO, A. Tentativa de explicação das causas que determinaram a expansão dos meios de pagamento em 1964 e 1965. Relatório Anpes: São Paulo, janeiro 1966.

DELFIM NETTO, A. "Considerações sobre a elasticidade da demanda dos cafés brasileiros" in Ensaios Econômicos: Homenagem a Octávio Gouvêa de Bulhões. APEC EDITORA; São Paulo, Rio de Janeiro, 1972.

DELFIM NETTO, A. PINTO, C. A. A. "O Problema do Café no Brasil” in INSTITUTO BRASILEIRO DO CAFÉ. Ensaios Sobre Café e Desenvolvimento Econômico. Insituto Brasileiro do Café: Rio de Janeiro, 1973. 
DELFIM NETTO, A. PINTO, C. A. A. “O café do Brasil: 20 anos de substituição no mercado" in INSTITUTO BRASILEIRO DO CAFÉ. Ensaios Sobre Café $e$ Desenvolvimento Econômico. Insituto Brasileiro do Café: Rio de Janeiro, 1973.

DELFIM NETTO, Antônio. Pastore, A. C. Cipollari, P. Carvalho, E. P. de. Alguns aspectos da inflação brasileira. Estudo ANPES $n .^{\circ}$ 1. São Paulo: ANPES, 1965.

DOMAR, E. D. “A Soviet Model of Growth" in Essays on The Theory of Economic Growth, Oxford University Press, New York, 1957.

DREIFUSS, R. A. 1964: A conquista do Estado. Ação política, poder e golpe de classe. Petrópolis: Vozes. 1981.

DREIFUSS, René. A internacional capitalista: estratégias e táticas do empresariado transnacional, 1918-1986. Rio de Janeiro: Editora Espaço e Tempo, 1986.

EPEA (Escritório de Pesquisa Econômica Aplicada), Ministério do Planejamento e Coordenação Econômica. O Programa de Ação e as Reformas de Base (vol. II).Dez. 1965.

ESTIMATIVA DA RENDA Nacional do Brasil 1947-1951 in: Revista Brasileira de Economia. Rio de Janeiro: Fundação Getúlio Vargas, v. 6, n4, 1952.

ESTIMATIVA DO INVESTIMENTO Bruto e Líquido no Brasil 1947-1951” in: Revista Brasileira de Economia. Rio de Janeiro: Fundação Getúlio Vargas, v. 6, n4, 1952.

FEA/USP, Anuário da faculdade de ciências econômicas e administrativas da universidade de são paulo, São Paulo: FEA/USP, 1946-1947.

FONSECA, P. C. D. "Legitimidade e Credibilidade: Impasses da Política Econômica do Governo Goulart" in Estudos Econômicos, São Paulo, v.34, n.3, 2004.

FRANCO, G. "Auge e Declínio do Inflacionismo no Brasil”. In: GIAMBIAGI, G; VILLELA, A.; CASTRO, L. B.; HERMANN, J. (Org.). Economia brasileira contemporânea (1945-2004). Rio de Janeiro: Campus Elsevier, 2005.

FRANCO, G. O Desafio Brasileiro: Ensaios sobre Desenvolvimento, Globalização e Moeda. Editora 34, 1996.

FRANCO, G.H.B., Reforma Monetária e Instabilidade Durante a Transição Republicana. Rio de Janeiro: BNDES, 1983. 
FRANKEL, M. "Producer Goods, Consumer Goods and Acceleration of Growth", Economic Journal, 1961.

FRIEDMAN, M. "The methodology of positive economics", in Essays in Positive Economics: The Methodology of Economics and Other Essays, Chicago: University of Chicago, 1953.

FRITSCH, W. External Constraints on Economic Policy in Brazil, 1889-1930. Londres: Macmillan, 1988.

FURTADO, C. [1959] Formação Econômica do Brasil. São Paulo: Cia das Letras, 2007.

FURTADO, C. "El Desequilibrio Externo en las Economías Subdesarrolladas" El trimestre Económico, vol. 25, $\mathrm{N}^{\circ} 98,1958$.

FURTADO, C. "Jean Marchal - Les Mécanisme dês Prix". in: Revista Brasileira de Economia. Rio de Janeiro: Fundação Getúlio Vargas, 1948.

FURTADO, C. "The External Disequilibrium in the Underdeveloped Economies", The Indian Journal of Economics, 1958.

GALBRAITH, John Kenneth. A Life in Our Times: Memoirs. Boston: Houghton Mifflin, 1981.

GEORGESCU-ROEGEN, N. "Economic Theory and Agrarian Economics" in Agriculture in Economic Development, McGraw-Hill, 1964.

GOODWIN, Craufurd D. "The patrons of economics in a time of transformation" in: MORGAN, M. RUTHERFORD, M. (Eds). From interwar pluralism to postwar neoclassicism (Annual supplement to volume 30 History of Political Economy).Duke University Press, 1998.

GOODWIN, R. M. "Optimal Growth Path for an Underdeveloped Economy, Economic Journal, 1961.

GUDIN, E. "Comércio internacional num mundo em desenvolvimento" in Digesto Econômico, São Paulo, v. 19, n. 164, 1962.

GUIMARÃES, A. P. Quatro Séculos de Latifúndio. Paz e Terra: Rio de Janeiro, 1977.

GUIMARÃES, M. H. Economia Política do Comércio Internacional: Teorias e Ilustrações. Cascais: Principia - Publicações Universitárias e Científicas, Lda, 2005. 
HABAKKUK, H. J. "The historical experience on the basic conditions of economic progress", in Economic progress, edited by Leon H. Dupriez, Louvain, 1955.

HERNÁNDEZ, O. R. "El Convencionalismo em Pierre Duhem y Henri Poincaré" in Revista de Filosofia de la Universidad de Costa Rica, 2002.

HICKS, J. R. The Review of River Plate, Buenos Aires, maio, 1962.

HOVART, B. “La Tasa Optima de Inversión”, Trimestre Económico, 1960.

HUDDLE, D. L. "Plano Trienal: Crítica do Setor Externo" in Revista Brasileira de Economia, v. 16, № 4, 1962.

HUDDLE, D.L. "O Sistema Brasileiro de Taxas Cambiais Flutuantes - Sua Equidade Distributiva, suas Relações com a Inflação e sua Eficiência” in Revista Brasileira de Economia. Rio de Janeiro: Fundação Getúlio Vargas, v. 26, n4, 1972.

HUMPHREY, T. M. "Historical Origins of the Cost-Push Fallacy" in Economic Review. Richmond: Federal Reserve Bank of Richmond, 1998.

HUMPHREY, T. M. "On Cost-Push Theories of Inflation in the Pre-War MonetaryLiterature" in Economic Review. Richmond: Federal Reserve Bank of Richmond, 1977.

KEYNES, J. N. The Scope and Method of Political Economy. Macmillan: Nova Iorque, 1904.

Kindleberger, Charles P. The Life of an Economist. Cambridge, Mass.: Basil Blackwell, 1991.

KINGSTON, J. “A Desigualdade na Distribuição das Rendas”. in: Revista Brasileira de Economia. Rio de Janeiro: Fundação Getúlio Vargas, 1952.

KINGSTON, J. "The Elasticity of Substitution of Brazilian Coffee" in Eighth American Scientific Congress, Washington, 1943.

KINGSTON, J. GUDIN, E. "A Taxa de Equilíbrio do Cruzeiro" in : Revista Brasileira de Economia. Rio de Janeiro: Fundação Getúlio Vargas, v.3, n 4, 1949.

KLEIN, J. ERICKSON, P. DASTON, L. LEMOV, R. STURM, T. GORDIN, M. How reason almost lost its mind, the strange career of cold war rationality. The University of Chicago Press, Chicago: 2013. 
KURZ, H. D. "Constantino Bresciani Turroni” in MEACCI, F. (org.) Italian Economists of the 20th Century. Edward Elgar Publishing Limited, 1998.

LAFER, C. "O convênio internacional do café (Versão revista)" in $3^{\circ}$ reunião do Grupo Interamericano de Estudos Jurídicos da Carnegie Endowment for International Peace, Venezuela, 1972.

LAFER, C. "O Plano de Metas" in LAFER, B. M. (org.). Planejamento no Brasil, São Paulo: Perspectiva, 1970.

LEIBENSTEIN, H. "The Theory of Underemployment in Backward Economies" in Journal of Political Economy, v. 65, 1957.

LEIBENSTEIN, H. "Underemployment in Backward Economies: Some Additional Notes" in Journal of Political Economy, v. 66, n. 03, 1958.

LEOPOLDI, M. A. "O Difícil Caminho do Meio: Estado, Burguesia Industrial e Industrialização no Segundo Governo Vargas (1951-1954)" in SZMRECSÁNYI, T. SUZIGAN, W. (org) História Econômica do Brasil Contemporâneo. Edusp: São Paulo, 2002.

LEVI, Primo. Os afogados e os sobreviventes: os delitos, os castigos, as penas, as impunidades. Rio de Janeiro: Paz e Terra, 1990.

LEWIS, A. W. "Economic Development with Unlimited Supplies of Labour" in The Manchester School of Economic and Social Studies, 1958.

LIMA, L. R. Torta de Algodão na Dieta de Cordeiros Confinados. Cuiabá: UFMT, 2012. Dissertação de mestrado.

LOUÇÃ, F. Terlica, S. "The fellowship of econometrics: selection and diverging views in the province of mathematical economics, from the 1930s to the 1950s" in History of political economics, 2011.

LOUREIRO, M. R. LIMA, G. T. “A Internacionalização da Ciência Econômica no Brasil" in Revista de Economia Política, v. 14, n.3, 1994.

MACEDO, R. “Antonio Delfim Netto” in Estudos Avançados. Vol. 15.N ${ }^{\circ} 43$ São Paulo Sept./Dec. , 2001. 
MACHLUP, F. “ANother View of Cost-Push and Demand-Pull Inflation” in The Review of Economics and Statistics. V. 42, n. 2, 1960.

MacIver, Robert M. Academic Freedom in Our Time. New York: Columbia

University Press, 1955.

MAGALHÃES, J. P. A. "Planejamento e a Experiência Brasileira" in Revista Brasileira de Economia, v. 16, № 4, 1962.

MANHALANOBIS, P. C. Some Observations on the Process of Growth of National Incoe, Sankhya, 1952.

MARCHAL, Jean. Le Mécanisme dês Prix. Librairie de Médicis: Paris, 1948.

MARX, K. O Capital: Crítica da Economia Política. Livro I: O Processo de Produção do Capital. São Paulo: Boitempo Editorial, 2011.

MONGIN, P. "Le Débat sur la Méthode en Économie (1932-1963) in Quaderni di Storia dell'Economia Politica, v.9, n.1, 1991.

MOVIMENTO DO ALGODÃO NA INDÚSTRIA TEXTIL MUNDIAL in Revista dos Mercados, São Paulo: Bolsa de Mercadorias de São Paulo, abril, 1954.

MUNHOZ, D. Entre Crises: 40 anos da economia do Brasil. Brasília: Thesaurus, 2012.

NATIVIDADE, M. M. A Questão Agrária no Brasil (1961-1964): uma arena de lutas de classe e interclasse. Dissertação (Mestrado em História Social) - Instituto de Ciências Humanas e Filosofia, Departamento de História, Universidade Federal do Rio de Janeiro, Rio de Janeiro.

OCAMPO, J. A., Colombia y la Economia Mundial, 1830-1910. México: Siglo XXI, 1984.

OLIVEIRA, A. J. Popper e o convencionalismo. UNESP: Marília, 2005. (Mestrado em Filosofia).

[Sem autor] Audiências Públicas 1995 (volume II) - Debate Econômico. Centro de Documentação e Informação. Coordenação e Publicações, Brasília:1996.

OLIVEIRA, Julio H. G. "On Structural Inflation and Latin-American 'Structuralism"” in Oxford Economic Papers, vol.XVI, N 3, nov. 1964. 
PAEG PROGRAMA DE AÇÃO ECONÔMICA DO GOVÊRNO 1964-1966 (Síntese) $2^{\circ}$ edição. Docuentos EPEA - N. ${ }^{\circ}$ 1. Maio de 1965.

PAIM, T. LOUVANDINI, H. MCMANUS, C. ABDALLA, A. "Uso de subprodutos do algodão na nutrição de ruminantes” in Ciência Veterinária nos Trópicos, v.13, 2010.

PASTORE, A. C. A Resposta da Produção Agrícola aos Preços no Brasil. Boletim 55 da Faculdade de Ciências Econômicas e Administrativas/Universidade de São Paulo, Cadeira III - Estatística I;Estatística Econômica; Econometria. São Paulo, 1968

PAUlA, J. A. "Caio Prado Júnior e o Desenvolvimento Econômico Brasileiro" in Pesquisa e Debate, São Paulo, v. 17, n.1, 2006.

PINHO, Diva Benevides. A FEA-USP no Tempo: Contribuição à Memória de Seus 60 Anos. São Paulo: FEA/USP, 2006.

PLANO TRIENAL DE DESENVOLVIMENTO ECONÔMICO E SOCIAL - 19631965 (SÍNTESE) - Presidência da República, Brasília, dezembro de 1962.

PLANO TRIENAL DE DESENVOLVIMENTO ECONÔMICO E SOCIAL (1963-1965) (Síntese), dez. 1962.

POPPER, K. The Logic of Scientific Discovery. Routledge: Londres e Nova Iorque, 2005.

PRADO JUNIOR, C. A Revolução Brasileira. Brasiliense: São Paulo, 1978.

PRADO JUNIOR, C. Diretrizes para uma política econômica brasileira. São Paulo: Brasiliense, 1954.

PREBISCH, R. [1949] "El desarrollo económico de la América Latina y algunos de sus principales problemas" in GURRIERI, A. La obra de Prebisch en la Cepal. México: Fondo de Cultura Económica, 1982.

PREBISCH, R. [1950] “Crecimiento, desequilibrio y disparidades: Interpretación del processo de desarrollo económico" in: GURRIERI, A. La obra de Prebisch en la Cepal. México: Fondo de Cultura Económica, 1982.

PREBISCH, R. [1951] "Problemas teóricos y prácticos del crecimiento económico" in: GURRIERI, A. La obra de Prebisch en la Cepal. México: Fondo de Cultura Económica, 1982. 
PREBISCH, R. "El Falso Dilema Entre Desarrollo Economico y Estabilidad Monetaria" in Boletin Economico de America Latina, Chile: Cepal, 1961.

PREBISCH, R. “O desenvolvimento da América Latina e seus principais problemas”, in Revista Brasileira de Economia, ano 3, n.3, Rio de Janeiro: Fundação GetúlioVargas, setembro de 1949.

RANGEL, I. [1963] "A Inflação Brasileira” in RANGEL, I. Obras Reunidas. Contraponto: Rio de Janeiro, 2012.

RANGEL, Ignácio. "Do ciclo ao Plano" in Economia Brasileira Contemporânea. São Paulo: Editora Bienal, 1987.

REMSEY, F.P. “A Mathematical Theory of Saving”, Economic Journal, 1928.

REVISTA DOS MERCADOS in Revista dos Mercados São Paulo: Bolsa de Mercadorias de São Paulo, abril, 1954.

ROBBINS, L. [1932] Um ensaio sobre a natureza e a importância da ciência econômica. São Paulo: Saraiva, 2012.

ROSENSTEIN-RODAN, P. N. "Disguised Unemployment and Underemployment in Agriculture" in Monthly Bulletin of Agricultural Economics and Statistics, v. 6, 1957.

ROWE, J. W. F. Markets and men. Cambridge, The University Press, 1936.

RUSSEL, B. El Panorama Científico, Santiago, 1937.

SAES, Alexandre Macchione; CYTRYNOVICZ, Roney; SAES, Beatriz; HESPANHOL, Giancarlo; BRUZZI CURI, Luiz Felipe. FIPE 40 anos. São Paulo: FIPE, 2014.

SAES, F. CYTRYNOWICZ, R. História da Ordem dos Economistas de São Paulo, 1935 2000: ensino, pesquisa e profissão de economista em São Paulo. São Paulo: Narrativa Um, 2001.

SAES, M. S. M. A racionalidade econômica da regulamentação do mercado brasileiro de café - SP. São Paulo: Faculdade de Economia, Administração e Contabilidade da USP, tese de doutorado, 1995

SAFATLE, Claudia. "Delfim Netto entrevistado por Valor Econômico" in Jornal Valor Econômico. São Paulo, 10 de fevereiro de 2012. Pode ser encontrado em 
http://www.asiacomentada.com.br/2012/02/delfim-netto-entrevistado-por-valoreconmico/. Último acesso em 07/04/2016.

SAMUELSON, P. "International trade and the equalisation of factor prices", in Economic Journal, 1948.

SAMUELSON, P. A. [1947] Foundations of Economic Analisys. Harvard University Press: Cambridge, 1971.

SAMUELSON, P. A. "International factor-price equalisation once again", in The economic jornal, 1949.

SAMUELSON, P. A. "Welfare Economics and International Trade" in The American Economic Review, v.28, n.2, 1938.

SAMUELSON, P. A. Foundations of Economic Analysis, Cambridge, 1953.

SARGENT, T. J. The demand for money during Hyperinflations under rational expectations: II. Minneapolis: Federal Reserva Bank of Minneapolis, 1976.

SCHULTZE, C. L. "Recent Inflation in the United States" Study Paper, Washington: U.S. Government Printing Office; U.S. Congress, $86^{\text {th }}$ Congress, $1^{\text {st }}$ Session, $n .1$, set. 1959.

SCHULTZE, C. Recent Inflation in the United States. Washington: Governement Print Office, 1959.

SCHUMPETER, J. A. [1954] History of Economic Analysis. Routledge, 2006.

SCREPANTI, E. ZAMAGANI, S. Na Outline of the History of Economic Thought. Oxford: Oxford University Press, 2005)

SELDEN, R.T. "Monetary Velocity in the United States" in FRIEDMAN, M., "Studies in the Quantaty Theory of Money", 1956.

SILVA, Hélio Schlittler, "A taxa de câmbio", in Revista de Ciências Econômicas, Ano XI, nº 71, jun-set, 1954.

SINGER, H. "O Mecanismo do Desenvolvimento Econômico" in Revista Brasileira de Economia, 1953. 
SINGER, H. W. "Mechanics of Economic Development," Indian Economic Review, August 1952

SMITH, G.W. "A Agricultura e o Plano Trienal” in Revista Brasileira de Economia, v. $16, \mathrm{~N}^{\circ} 4,1962$.

SMITH, N. M. "The Role of Intuition in the Scientific Method" in Proceedings of the Eighth Conference on the Design of Experiments in Army Research Development and Testing. Defense Technical Information Center Compilation Part Notice, s/d.

SOARES, P. T. "Convergências entre Ignácio Rangel e Delfim Netto: uma leitura com base em Lenin" in HOLANDA, F. M. ALMADA, J.U.P. S. PAULA, R. Z. A. (orgs). Ignácio Rangel: decifrador do Brasil. São Luís: Edufma, 2014.

SOARES, P. T. "Prebisch (1949): Contestação à Teoria Econômica Convencional e Utopia Reformadora” in IX Encontro Nacional de Economia Política, 2004.

SOARES, P. T. P. L. Um Estudo Sobre Lenin e as Defesas da Reforma Agrária no Brasil. FEA/USP: São Paulo, FEA/USP: 1992. (Tese de Doutorado).

SOARES, P. T. P. L. Crise dos Anos 1960: um estudo dos diagnósticos de Rangel, Simonsen, Singer e Tavares. FEA/USP: São Paulo, 1981. (Dissertação de Mestrado)

SODRÉ, N. W. Capitalismo e revolução burguesa no Brasil. Rio de Janeiro: Graphia Editorial, 1997.

SUNKEL, O. "La inflación Chilena - Um enfoque Heterodoxo"., in El Trimestre Econômico, Cidade do México, n ${ }^{\circ}$ 100, outubro/dezembro, 1958.

SUPLICY, E. "Os Efeitos das Minidesvalorizações da Taxa de Câmbio Sobre às Exportações Brasileiras" in Revista de Administração de Empresas, vol. 14, n 6, São Paulo: 1974.

SZMRECSÁNYI, T. SUZIGAN, W. (org) História Econômica do Brasil Contemporâneo. Edusp: São Paulo, 2002.

TAVARES, M. C. “Auge y Declinacion del Proceso de Sustitucion de Importaciones en el Brasil" in Boletin Economico de America Latina. Nova Iorque: Cepal (Comision Economica para America Latina), vol. IX, N. ${ }^{\circ}$, março 1964. 
TAVARES, M. C. Acumulação de Capital e Industrialização no Brasil. Rio de Janeiro: mimeo., 1975.

TINBERGEN, J. “The Optimal Rate of Saving” in Economic Journal, 1956.

TOOKE, T. An Inquiry into the Currency Principle; The Connection of the Currency with Prices, and the Expediency of a Separation of Issue from Banking 2d ed. London: Longman, Brown, Green, and Longmans, 1844, reprinted as No. 15 in Series of Reprints of Scarce Works on Political Economy, London: The London School of Economics and Political Science, $\quad 1964 . \quad$ Disponível em https://archive.org/details/inquiryintocurre00tookuoft. Acesso em 12/06/04.

TOTONCHI, J. "Macroeconomic Theories of Inflation" in International Conference on Economics and Finance Research IPEDR, vol.4 IASCIT Singapura: 2011.

TURRONI, COSTANTINO BRESCIANI. "Sul Carattere Delle “ Leggi Statistiche „,." Giornale Degli Economisti E Rivista Di Statistica, Serie Terza, 40 (Anno 21), no. 3 (1910): 269-92. http://www.jstor.org/stable/23223416, acessado em 08/10/2017.

TURRONI-BRESCIANI, C. The Economics of Inflation: a Study of Currency Depreciation in Post-War Germany. Grã-Bretanha: John Dickens \& Co Ltd, 1968.

UNIVERSIDADE DE SÃO PAULO. Faculdade de Economia e Administração. Economia: pessoas: professores eméritos: Antonio Delfim Netto. Disponível em: < https://www.fea.usp. br/economia/pessoas/professores-emeritos/antonio-delfim-netto >. Acesso em: 15/10/2017.

VIEIRA, D. T. “O Café Diante da Lei da Formação dos Preços” in Anuário da Faculdade de Ciências Econômicas e Administrativas da Universidade de São Paulo, 1946-1947.

VIEIRA, D. T. A Futura Política Econômica e Financeira do Brasil. Universidade de São Paulo, Faculdade de Ciência Econômicas e Administrativas. Cadeira XX: Valor e Preços; Moeda e Crédito; Comércio Internacional e Câmbio, boletim №17, 1961.

VILLELA, A. "Dos 'Anos Dourados' de JK à Crise Não Resolvida” in GIAMBIAGI, F. VILLELA, A. CASTRO, L.B. HERMANN, J. Economia Brasileira Contemporânea: 1945-2010. Rio de Janeiro: Elsevier, 2011.

VILLELA, A. "Os Transportes e o Plano Trienal" in Revista Brasileira de Economia, v. 16, $\mathrm{N}^{\circ} 4,1962$. 
VILLELA, A. V. SUZIGAN, W. [1973] Política do governo e crescimento da economia brasileira 1889-1945. Brasília: IPEA, 2001.

WONG, S. "The 'F-Twist' and the Methodology of Paul Samuelson" in The American Economic Review, v.63, n.3, 1973 